UNIVERSIDADE DE SÃO PAULO

INSTITUTO DE GEOCIÊNCIAS

\title{
ESTADO DE CONSERVAÇÃO DOS MONUMENTOS PÉTREOS DO CEMITÉRIO DA CONSOLAÇÃO, SÃO PAULO
}

\section{Luciane Kuzmickas}

Orientadora: Eliane Aparecida Del Lama

\author{
DISSERTAÇÃO DE MESTRADO \\ Programa de Pós-Graduação em Mineralogia e Petrologia
}

São Paulo 
Estado de Conservação dos Monumentos Pétreos do Cemitério da Consolação, São Paulo

\begin{abstract}
Dissertação de Mestrado submetida ao programa de Pós-Graduação em Mineralogia e Petrologia, Instituto de Geociências, da Universidade de São Paulo - USP, como parte dos requisitos necessários à obtenção de grau de Mestre em Ciências (Geologia).
\end{abstract}

Área de concentração:

Mineralogia Experimental e Aplicada

Orientadora:

Profa $^{a}$. Dra ${ }^{a}$. Eliane A. Del Lama 
Autorizo a reprodução e divulgação total ou parcial deste trabalho, por meio convencional ou eletrônico, desde que citada a fonte.

Ficha catalográfica preparada pelo Serviço de Biblioteca e Documentação do Instituto de Geociências da Universidade de São Paulo

Kuzmickas, Luciane

Estado de conservação dos monumentos pétreos do Cemitério da Consolação, São Paulo / Luciane Kuzmickas. - São Paulo, 2013.

150 p.: il + anexos

Dissertação (Mestrado): IGc/USP

Orient.: Del Lama, Eliane Aparecida

1. Cemitério da Consolação 2. Mineralogia aplicada 3. Conservação de monumentos 4. Métodos não destrutivos I. Título 
Aos meus antepassados que transpuseram cerca de $10.400 \mathrm{~km}$, distância que separa a Lituânia do Brasil, pela simples necessidade de sobrevivência. 


\section{AGRADECIMENTOS}

A minha orientadora Eliane Aparecida Del Lama pela confiança, paciência e ajuda nesses seis anos de convivência e aprendizado. Jamais me esquecerei das suas primeiras palavras: eu estava esperando um orientado de mestrado para oferecer esse tema, mas como apareceu você... Vai dar uma volta no Cemitério da Consolação e vê se gosta.

A Jose Delgado Rodrigues pela oportunidade de participaçãono Charisma Course on Stone Conservation, que ocorreu em Portugal em 2012, e a todos os outros professores e colegas os quais tive o prazer de conhecer. Essa dissertação é sem dúvida, o fruto de tudo que aprendi com vocês.

À Assessoria de Imprensa do Serviço Funerário da Cidade São Paulo, pelas autorizações concedidas, e a todos os funcionários do Cemitério da Consolação, pela colaboração com o desenvolvimento dos estudos.

Aos colegas da pós-graduação pela troca de experiências e pelo ambiente agradável de trabalhar. À Aline Mota (Massacrada) e Mariana Tiisel Yamamoto (VooDoo), por nunca se esquecerem de mim, mesmo eu sendo uma amiga super relapsa.

Ao Bandeirante Rugby Club Feminino, por todo apoio dentro e fora campo, e pelo aprendizado e treinamento da paciência concedido. A Maêva Berenguel que me ajudou a terminar a dissertação em meio acaça de inúmeros vagalumes.

À equipe de orientados da Prof. ${ }^{a}$ Eliane, por acreditarem que o respeito e a salvaguarda do patrimônio cultural brasileiro ainda seráimportantenesse país.

À Fundação de Amparo a Pesquisa do Estado de Paulo (FAPESP), pelas bolsas de iniciação (Proc. n. 2007/08329-0) e mestrado (Proc. n. 2010/13910-7) concedidas, e pelo projeto de pesquisa (Proc. n. 2009/02519-8) que proporcionou a aquisição dos equipamentos utilizados nesta dissertação.

Muito obrigada ao meu Deus e aos meus antepassados por me auxiliarem no desenvolvimento dessa escolha, uma das melhores da minha vida, que me proporcionou conhecimento e sabedoria que serão aplicados por toda a minha existência. Namastê! 
Debaixo dos pés de cada geração que passa na terra, dormem as cinzas de muitas gerações que a precederam.

- Alexandre Herculano - 


\section{RESUMO}

Os cemitérios são importantes fontes de resgate da memória, revelando concepções e mentalidades de épocas passadas. São locais simbólicos com rico acervo patrimonial, no que diz respeito à vida cultural, social e estética de uma dada população. No caso do Cemitério da Consolação, São Paulo, fundado em 1858, as várias etapas de desenvolvimento da cidade na qual se insere e do Brasil, estão presentes na localização, ornamentação e nos materiais empregados na construção dos túmulos, sendo a conservação desse patrimônio extremamente importante. O presente estudo propõe avaliar o estado de conservação do Cemitério da Consolação, utilizando-se métodos de análise não destrutivos, o que compreende: análise bibliográfica e iconográfica; determinação da variabilidade litológica existente; mapeamento das formas de alteração da rocha com base no Glossário Ilustrado de Padrões de Deterioração da Rocha do ICOMOS; quantificação da variação da cor da rocha com utilização do espectrofotômetro e avaliação da homogeneidade da rocha por meio da utilização do ultrassom. O mapeamento das formas de alteração compreendeu todos os litotipos existentes, enquanto as análises com 0 espectrofotômetro e com o ultrassom foram realizadas em mármores, abrangendo o túmulo da Marquesa de Santos, o da Pianista Luisa Crema Marzorati e a escultura Prece de Bruno Giorgi, e em um tipo específico de granito, conhecido comercialmente como Granito Itaquera, que constitui as estátuas O Sepultamento de Victor Brecheret, Interrogação de Francisco Leopoldo e Silva e Cristo de Elio de Giusto. O mapeamento das formas de alteração da rocha indicou nos túmulos a presença de: fissura, deformação, rompimento, desintegração, descamação, alveolização, erosão diferencial, perda de partes, perfuração, crosta, depósito, alteração cromática, eflorescência, incrustação, filme, grafite, pátina, sujidade e colonização biológica por líquen, musgo e planta. Foi possível constatar que as rochas carbonáticas são as que se apresentam mais degradadas, possuindo todas as formas de alteração indicadas, que se apresentam em diferentes estágios de desenvolvimento. As rochas silicáticas e silicosas desenvolvem menos formas de degradação, também em distintas intensidades, abrangendo a alteração cromática, sujidade, depósito e colonização biológica. Os dados obtidos com o espectrofotômetro evidenciaram mudanças significativas nos parâmetros de cor no Granito Itaquera e nos mármores, principalmente em variações relativas aos parâmetros colorimétricos b* e $C^{*}$, indicando amarelamento da rocha. Com os resultados do ultrassom foi possível mapear zonas de menor e maior integridade pétrea nos jazigos e esculturas estudados. A partir das análises realizadas foi possível determinar os principais 
mecanismos de degradação existentes no Cemitério da Consolação, que estão vinculados à: natureza litológica, interação de materiais, poluição atmosférica, colonização biológica, condições climáticas, características arquitetônicas, vandalismo, falta de gerenciamento e métodos inadequados de conservação e restauro. Desta forma conclui-se que o Cemitério da Consolação necessita de medidas de conservação que foquem principalmente os seguintes aspectos: maior vigilância do cemitério a fim de ser evitar o roubo da ornamentação de bronze; qualificar os funcionários da necrópole no que tange a aplicação de métodos de manutenção menos agressivos às rochas; conscientização das famílias dos problemas que o abandono e o descaso podem causar aos jazigos, promovendo assim a importância da sua manutenção. Por fim cabe lembrar que o Cemitério da Consolação pode ser considerado como um museu a céu aberto, devendo ser administrado, preservado e zelado como tal. 


\section{ABSTRACT}

Cemeteries are important sources of memory rescue, revealing conceptions and mentalities of the past. They are symbolic locations with rich heritage, with regard to cultural, social and aesthetic aspects of a given population. In the case of the Consolation Cemetery, São Paulo, founded in 1858, the various stages of development of the city and of the country can be observed in the location, ornamentation and materials used in the construction of the tombs, and the conservation of this heritage is extremely important. This study aims to assess the state of conservation of the Consolation Cemetery, using non-destructive methods of analysis, which comprises: bibliographic and iconographic analyses; determination of lithological variability; mapping of the forms of alteration of the rock based on the Illustrated Glossary on Stone Deterioration Patterns of ICOMOS; quantification of the color variation of the rock using the spectrophotometer and evaluation of the homogeneity of the rock through the use of ultrasound. The mapping of the deterioration patterns included all the rock types in the cemetery, while analyses with the spectrophotometer and the ultrasound were performed in marble, material used in the tombs of Marquesa de Santos, the pianist Luisa Crema Marzorati and a sculpture by Bruno Giorgi, as well as in a specific type of granite, known commercially as Itaquera Granite, which constitutes the statue O Sepultamento by Victor Brecheret, Interrogação by Francisco Leopoldo e Silva and Cristo by Elio de Giusto. The mapping of the deterioration patterns indicated the presence of: crack, deformation, bursting, disintegration, scaling, alveolization, differential erosion, missing part, perforation, crust, deposit, discolouration, efflorescence, encrustation, film, graffiti, patine, soiling, and biological colonization by lichen, moss or plant. The carbonate rocks are the most degraded, possessing all deterioration patterns indicated above, which are in different stages of development. The silicate and siliceous rocks developed fewer deterioration patterns, also in different intensities, such as discolouration, soiling, deposit and biological colonization. The information obtained from the spectrophotometer showed significant changes in the Itaquera Granite and marble color parameters, especially in $C^{*}$ and $b^{*}$ colorimetric parameters, indicating yellowness of the rock. With the results of the ultrasound it was possible to map areas in the stone with lesser and greater integrity. From the analyses, it was possible to determine the main degradation mechanisms existing in the Consolation Cemetery, such as: lithological nature, interaction of materials, pollution, biological colonization, climatic conditions, architectural features, vandalism, bad management and inadequate methods of conservation and restoration. Thus, it is concluded that the Consolation Cemetery requires conservation measures that focus 
mainly on the following aspects: to increase vigilance of the cemetery to detain the theft of bronze ornamentation; qualify the cemetery employees regarding the application of maintenance methods less aggressive to the rocks; raise of the families to the problems of abandonment and neglect of the tombs, thus promoting the importance of their maintenance. Finally, it is worth remembering that the Consolation Cemetery can be considered an open air museum and should be managed, preserved and taken care of as such. 


\section{ÍNDICE DE FIGURAS}

Figura 1.Localização do Cemitério da Consolação, São Paulo - SP. __ 4

Figura 2.Determinação do tempo de propagação das ondas ultrassônicas na estátua de mármore. Método de transmissão direta.

Figura 3.Determinação do tempo de propagação das ondas ultrassônicas no túmulo em granito. Método de transmissão indireta.

Figura 4. Determinação dos parâmetros colorimétricos da estátua em granito, utilizando o espectrofotômetro.

Figura 5. Determinação dos parâmetros colorimétricos da estátua em mármore, utilizando o espectrofotômetro.

Figura 6. Entrada principal do Cemitério da Consolação em 1916.

14

Figura 7. Entrada principal do cemitério da Consolação, ao fundo a capela. Fotografado em 26 de junho de 2008, dia do enterro da ex-primeira dama Ruth Cardoso.__ 14

Figura 8. Cemitério da Consolação em 1887.

Figura 9. Fotografia do Cemitério da Consolação retratando a inauguração do mausoléu simbólico que a comunidade francesa construiu em memória de Sadi Carnot em 14 de julho de 1894.

Figura 10. Fotografia do sepultamento do ex-presidente Bernardino de Campos, em 1915. 17

Figura 11. Fotografia do sepultamento do maestro Luiz Chiaffarelli no Cemitério da

Consolação, em 1923.

Figura 12. Vista aérea da rua da Consolação em 1968, mostrando com maior detalhe o

Cemitério da Consolação. Fotógrafo: Ivo Justino.

Figura 13. Rua da Consolação em 1968, em frente ao cemitério da Consolação (lado

esquerdo). Fotógrafo: Ivo Justino.

Figura 14. Fotografia da Marmoraria Tavolaro, que se localizava na Rua da Consolação, 98.

Possuía exposição permanente de túmulos em mármore e granito, além de grande variedade

de estatuária, vasos e cruzes.

Figura 15. Anúncio comercial da Marmoraria Tavolaro na revista "A Cigarra".

Figura 16. Pavimentação com seixos de sílex.

Figura 17. Revestimento da janela constituído por alabastro. 26

Figura 18. Mica sendo utilizada na constituição do concreto (seta vermelha). _L 26

Figura 19. Geodo de quartzo. _L 26

Figura 20. Parte posterior do geodo; presença de cristais idiomórficos de calcita. __ 26

Figura 21. Fissuramento da ornamentação em mármore. __ 31

Figura 22. Fissuramento da tampa em mármore. 31

Figura 23. Deformação côncava da lápide em mármore.__ 31

Figura 24. Deformação côncava da tampa em mármore._ 31

Figura 25. Início do rompimento da pilastra em calcário fossilífero (Fotografado no dia

22/01/2009)

Figura 26. Após ocorrer o rompimento da pilastra em calcário fossilífero (Fotografado no dia 29/07/2011).

Figura 27. Desintegração do mármore tipo sugaring.

Figura 28. Detalhe da Figura 27 da desintegração do mármore. __ 32

Figura 29. Descamação do Granito Itaquera. 32

Figura 30. Descamação do Granito Preto Bragança.__ 32

Figura 31. Alveolização do mármore.

Figura 32. Alveolização do mármore. 32

Figura 33. Erosão diferencial no mármore.__ 33

Figura 34. Erosão diferencial no mármore. 33

Figura 35. Perda das mãos da estátua.

Figura 36. Perda das cabeças das estátuas. __ 33

Figura 37. Perfuração da estátua em mármore. 33

Figura 38. Perfuração do túmulo em Granito Itaquera.___ 33

Figura 39. Crosta negra na ornamentação em mármore.__ 34

Figura 40. Crosta negra na estátua em mármore. —— 34

Figura 41. Depósito de fuligem no mármore. 34

Figura 42. Depósito de fezes de pombos na estátua de bronze na tampa do túmulo em Preto

Bragança. 34

Figura 43. Alteração cromática do mármore. __ 34 
Figura 44. Alteração cromática do granito vermelho.

Figura 45. Eflorescência no túmulo em mármore.

Figura 46. Eflorescência na placa de identificação em calcário fossilífero. 35

Figura 47. Concreção no túmulo em Granito Itaquera.

Figura 48. Concreção no túmulo em mármore.__ 35

Figura 49. Aplicação de tinta no túmulo em mármore. _ 35

Figura 50. Aplicação de tinta no portal de entrada do cemitério em Granito Itaquera.__ 35

Figura 51. Grafite no túmulo em mármore. _ـ 36

Figura 52. Grafite no túmulo em mármore.__ 36

Figura 53. Patina amarelada no túmulo em mármore. _ـ 36

Figura 54. Patina amarelada no túmulo em mármore. 36

Figura 55. Sujidade na estátua em mármore.___ 36

Figura 56. Sujidade no túmulo em quartzito.__ 36

Figura 57. Colonização biológica por liquens na estátua em mármore.___ 37

Figura 58. Colonização biológica por musgos no túmulo de mármore. —_ 37

Figura 59. Colonização biológica por plantas no túmulo em mármore. __ 37

Figura 60. Ninho de pássaros no túmulo em mármore. __ 37

Figura 61. Espaço de cor CIELAB. — 40

Figura 62. Espaço de cor CIELCh. 40

Figura 63. Portal de entrada do cemitério da Consolação no inicio do século $X X$. _ 51

Figura 64. Portal de entrada do cemitério da Consolação em 2012. As letras A, $B, C$ e $D$ indicam os locais analisados.

Figura 65. Detalhe do local analisado A.___ 52

Figura 66. Detalhe do local analisado B.__ 52

Figura 67. Detalhe do local analisado C. _ 52

Figura 68. Detalhe do local analisado D. 52

Figura 69. Gráfico utilizado na determinação do número mínimo de medidas necessárias para

obter o valor representativo da média do parâmetro colorimétrico $L^{*}$. _ـ 53

Figura 70. Gráfico utilizado na determinação do número mínimo de medidas necessárias para

obter o valor representativo da média do parâmetro colorimétrico $a^{*}$. _ـ 53

Figura 71. Gráfico utilizado na determinação do número mínimo de medidas necessárias para

obter o valor representativo da média do parâmetro colorimétrico $b^{\star}$. _ـ 53

Figura 72. Diagrama de dispersão cartesiano para as variáveis $C^{*} e L^{*}$ obtidas no dia 30/07/2010.

Figura 73. Diagrama de dispersão polar para as variáveis a* e b* obtidas no dia 30/07/2010. 57

Figura 74. Gráfico de reflectância espectral para os dados obtidos no dia 30/07/2010. __ 57

Figura 75. Diagrama de dispersão cartesiano para as variáveis $C^{*} e L^{*}$ obtidas no dia 05/04/2011.

Figura 76. Diagrama de dispersão polar para as variáveis a* e b* obtidas no dia 05/04/2011. 58

Figura 77. Gráfico de reflectância espectral para os dados obtidos no dia 05/04/2011. ___ 59

Figura 78. Diagrama de dispersão cartesiano para as variáveis $C^{*} e L^{*}$ obtidas no dia 02/04/2012.

Figura 79. Diagrama de dispersão polar para as variáveis a* e b* obtidas no dia 02/04/2012. 60

Figura 80. Gráfico de reflectância espectral para os dados obtidos no dia 02/04/2012. __ 60

Figura 81. Diagrama de dispersão cartesiano para as variáveis $C^{*}$ e $L$ * obtidas no dia 14/08/2012.

Figura 82. Diagrama de dispersão polar para as variáveis a* e b* obtidas no dia 14/08/2012. 61

Figura 83. Gráfico de reflectância espectral para os dados obtidos nodia 14/08/2012.___ 62

Figura 84. Túmulo da Família Pereira Pinto, notando-se intensa alteração cromática do jazigo.

\begin{tabular}{ll}
\hline Figura 85. Perda de partes da rocha. & 63
\end{tabular}

Figura 86. Descamação do granito Itaquera. __ 63

Figura 87. Primeiro nível do túmulo analisado pela velocidade das ondas ultrassônicas. __ 64

Figura 88. Quarto nível do túmulo analisado pela velocidade das ondas ultrassônicas. ___ 64

Figura 89. Esquema das análises realizadas no primeiro nível do túmulo. ___ _ 64

Figura 90. Esquema das análises realizadas no quarto nível do túmulo.___ 64

Figura 91. Diagrama de dispersão cartesiano para as variáveis $C^{*} e L^{*}$.__ 66

Figura 92. Diagrama de dispersão polar para as variáveis $C^{*}$ e $H^{\circ}$.___ 66

Figura 93. Gráfico de reflectância espectral.___ 66 
Figura 94. Notar partes esverdeadas e presença de liquens (setas vermelhas) na região da testa da estátua.

Figura 95. Partes próximas as inscrições em bronze com ausência de alteração cromática, evidenciando que a mudança na cor da rocha é devido à colonização biológica. Nesse caso o bronze funcionou como biocida natural.

Figura 96. Localização dos pontos estudados, na parte anterior da estátua, pela velocidade das ondas ultrassônicas.

Figura 97. Localização dos pontos estudados, na parte posterior da estátua, pela velocidade das ondas ultrassônicas.

Figura 98. Diagrama de dispersão cartesiano para as variáveis $C^{*} e L^{*}$

Figura 99. Diagrama de dispersão polar para as variáveis $C^{\star} e H^{\circ}$.

Figura 100. Gráfico de reflectância espectral.__ 71

Figura 101. Parte posterior da estátua fotografadano dia 21/08/2008._ 74

Figura 102. Detalhe da região do túmulo com maior degradação, apresentando uma alteração

cromática bastante evidente. 74

Figura 103. Parte posterior da estátua fotografada no dia 08/03/2013. __ 74

Figura 104. Detalhe da mesma região já bastante degrada em 2008, notando-se o aumento das dimensões da alteração cromática.

Figura 105. Localização dos pontos estudados no dia 03/04/2012, pela velocidade das ondas

ultrassônicas.

Figura 106. Localização dos pontos estudados no dia 01/08/2012, pela velocidade das ondas ultrassônicas.

Figura 107. Localização dos pontos estudados no dia 03/04/2012 e valores das velocidades das ondas ultrassônicas calculadas.

Figura 108. Localização dos pontos estudados no dia 01/08/2012 e valores das velocidades das ondas ultrassônicas calculadas.

Figura 109. Localização dos pontos estudados no dia 03/04/2012 e valores das velocidades das ondas ultrassônicas calculadas.

Figura 110. Localização dos pontos estudados no dia 01/08/2012 e valores das velocidades das ondas ultrassônicas calculadas.

Figura 111. Diagrama de dispersão cartesiano para as variáveis $C^{*}$ e $L^{*}$.

Figura 112. Diagrama de dispersão polar para as variáveis $C^{\star} e H^{\circ}$.

Figura 113. Gráfico de reflectância espectral.__ 81

Figura 114. Alteração cromática para tons de amarelo e laranja. ___ 83

Figura 115. Alteração cromática para tons de amarelo devido à alteração de alguns minerais.

Figura 116. Perda de partes relacionada à alteração das zonas micáceas. ___ 84

Figura 117. Locais analisados e métodos de transmissão utilizados. —— 84

Figura 118. Diagrama de dispersão cartesiano para as variáveis $C^{*} e \overline{L^{*} \text {. }} 87$

Figura 119. Diagrama de dispersão polar para as variáveis $C^{\star} e H^{\circ}$.

Figura 120. Gráfico de reflectância espectral.__ 87

Figura 121. Estátua Prece fotografada no dia 28/10/2011, notando-se amarelamento da base

de sustentação da escultura.

Figura 122. Estátua Prece fotografada no dia 14/08/2012, notando-se além do amarelamento,

o escurecimento de alguns locais. __ 89

Figura 123. Localização dos locais de análise pela velocidade de propagação das ondas ultrassônicas.

Figura 124. Diagrama de dispersão cartesiano para as variáveis $C^{\star}$ e $L^{*}$ _ 92

Figura 125. Diagrama de dispersão polar para as variáveis $C^{\star} e H^{\circ}$. 92

Figura 126. Gráfico de reflectância espectral.__ 93

Figura 127. Locais onde foram realizadas as medidas pelo método de transmissão direta. _ 95

Figura 128. Locais onde foram realizadas as medidas pelo método de transmissão direta e semidireta.

Figura 129. Diagrama de dispersão cartesiano para as variáveis $C^{*} e L^{*}{ }^{*}$

Figura 130. Diagrama de dispersão polar para as variáveis $C^{\star} e H^{\circ}$. 98

Figura 131. Gráfico de reflectância espectral.__ 98

Figura 132. Jazigo da Marquesa de Santos, notar sua descaracterização pela pintura da base, com tinta látex, e pelo amarelamento do pedestal. 101 
Figura 133. Localização dos locais estudados pela velocidade de propagação das ondas ultrassônicas (Pilares) e pela utilização do espectrofotômetro (Locais indicados pelas setas).

Figura 134. Diagrama de dispersão cartesiano para as variáveis $C^{*} e L^{*}$ _ 103

Figura 135. Diagrama de dispersão polar para as variáveis $C^{*} e H^{\circ}$. 103

Figura 136. Gráfico de reflectância espectral.__ 103

Figura 137. Cavidades geradas pela alteração de minerais opacos. 107

Figura 138. Erosão diferencial, com preservação da matriz e dissolução do conteúdo fossilífero.

Figura 139. Escamação do Granito Preto Bragança.___ 107

Figura 140. Forma de alteração intensa no Granito Itaquera. __ 107

Figura 141. Alteração cromática do mármore. Letras provavelmente confeccionadas em ferro.

108

Figura 142. Alteração cromática do travertino. Estátua provavelmente confeccionada em cobre ou bronze.

Figura 143. Alteração cromática do granito. Estátuas provavelmente confeccionadas em cobre ou bronze.

108

Figura 144. Escurecimento do mármore devido à presença de depósitos de fuligem. _ 111

Figura 145. Perda da definição da lápide devido à dissolução do mármore. __ 111

Figura 146. Setas azuis indicando zonas com desagregação granular, dissolução e alteração

cromática. Seta vermelha indica presença de crosta negra. 111

Figura 147. Desagregação granular e fissuramento do mármore. 111

Figura 148. Perda do reboco do túmulo devido à ação de raízes. — 112

Figura 149. Perda do reboco do túmulo devido à ação de raízes. 112

Figura 150. Área do Cemitério da Consolação delimitada pela linha vermelha. Microclimas 1 e

2 delimitados pela linha amarela._ 113

Figura 151. Microclima 1, ambiente úmido e com grande quantidade de árvores. Notar musgos

colonizando a pavimentação. 113

Figura 152. Microclima 2, ambiente seco, onde o intemperismo físico prevalece.__ 113

Figura 153. Túmulo do ex-presidente do Estado de São Paulo Bernardino de Campos em 1919.

Figura 154. Túmulo do ex-presidente do Estado de São Paulo Bernardino de Campos na década de 1970.

Figura 155. Túmulo do ex-presidente do Estado de São Paulo Bernardino de Campos em 2013.

Figura 156. Escultura Interrogação de Francisco Leopoldo e Silva. Seta indica zona com acúmulo de água.

Figura 157. Zona com acúmulo de água, notando-se proliferação de micro-organismos e alteração cromática da região.

Figura 158. Adição de areia a zona de acúmulo de água.

Figura 159. Ausência do portão de bronze.

Figura 160. Colocação de um portão em rocha devido o roubo do antigo portão em bronze 118

118

Figura 161. Túmulo da pintora Tarsila do Amaral no dia 10 de fevereiro de 2008.

Figura 162. Túmulo da pintora Tarsila do Amaral no dia 22 de janeiro de 2009. Ausência do vaso de bronze.

Figura 163. Túmulo de Luisa Crema Marzoratti, fotografado entre os anos de 1960 e 1970,

apresentando todas as suas alegorias em perfeito estado de conservação. 119

Figura 164. Túmulo de Luisa Crema Marzoratti, fotografado no dia 26 de junho de 2008. As

setas vermelhas indicam a ausência de elementos da composição. 119

Figura 165. Túmulo de Luisa Crema Marzoratti, fotografado no dia 02 de abril de 2012. A seta

em vermelho indica a perda de mais um elemento do túmulo. __ 119

Figura 166. Bastante sujeira e fezes dentro de jazigo.__ 120

Figura 167. Indivíduos tomando banho e lavando roupa numa torneira no cemitério.__ 120

Figura 168. Notar alteração cromática por todo o mausoléu. _ـ 123

Figura 169. Alteração cromática devido à precipitação do zinabre proveniente das estátuas de

bronze.

Figura 170. Perda de partes.__ 123

Figura 171. Incrustação. 123

Figura 172. Grafite. 123 
Figura 173. Orifícios, gerados pela alteração de minerais opacos, preenchidos com argamassa.

Figura 174. Material utilizado para rejunte dos blocos de granito não se mostrou adequado,

proporcionando o escurecimento da rocha.

Figura 175. Detalhe do material utilizado no rejunte dos blocos. __ 124

Figura 176. Eflorescência. 124

Figura 177. Crosta negra. 124

Figura 178. Rompimento. 124

Figura 179. Seta vermelha indica local que já ocorreu o rompimento e a seta azul alteração cromática em função da queima de velas.

Figura 180. Fotografia da entrada do cortejo fúnebre do Conde Alexandre Siciliano, no

Cemitério da Consolação, em 1923. 126

Figura 181. Fotografia do sepultamento do Conde Alexandre Siciliano no Cemitério da Consolação, em 1923.

Figura 182. Túmulo do Conde Siciliano na década de 1970. 127

Figura 183. Túmulo do Conde Sicialiano em 22 de janeiro de 2009._ 127

Figura 184. Túmulo do Conde Sicialiano em 08 de março de 2013. __ 127

Figura 185. Sujidade na parede lateral inferior do mausoléu em mármore._ 128

Figura 186. Alteração cromática do mármore (amarelamento) e a presença de uma colmeia

(seta vermelha).

Figura 187. Alteração cromática do altar, busto e revestimento em mármore. __ 129

Figura 188. Falta de limpeza do mausoléu. — 129

Figura 189. Degradação das pinturas existentes nas paredes. __ 129

Figura 190. Degradação das pinturas existentes no teto.__ 129

Figura 191. Setas indicando locais com crosta negra. _ـ 129

Figura 192. Setas indicando locais com crosta negra. 129

Figura 193. Base de sustentação, em granito, com sujidade e setas indicando a ausência das

argolas.

Figura 194. Grafite próximo a porta de acesso. 130

Figura 195. Colonização biológica antes da limpeza.__ 131

Figura 196. Ausência de colonização biológica após a limpeza e excessivo clareamento da rocha.

Figura 197. Notar os depósitos superficiais no anjo (partes escuras) antes da limpeza.

Figura 198. Notar a ausência dos depósitos superficiais no anjo após a limpeza e excessivo

branqueamento.

Figura 199. Setas indicam locais com substituição do mármore.___ 133

Figura 200. Túmulo da Família Pilla.__ 133

Figura 201. Aplicações de parafusos para a fixação das laterais do vaso. ___ 133

Figura 202. Fotografia do túmulo da Marquesa de Santos em 1969. As setas indicam os locais

antes da pintura com tinta látex. 134

Figura 203. Fotografia do túmulo da Marquesa de Santos em 2013. As setas indicam os locais

que foram pintados com a tinta látex.

Figura 204. Vedação do túmulo em mármore, após sepultamento, com tijolos e cimento. — 135

Figura 205. Escultura em mármore colada com cimento.__ 135

Figura 206. Pintura da estátua de mármore com látex. — 135 


\section{ÍNDICE DE TABELAS}

Tabela 1. Rochas carbonáticas identificadas no Cemitério da Consolação. 23

Tabela 2. Rochas silicosas e rochas síltico-argilosas foliadas identificadas no cemitério da Consolação.

Tabela 3. Rochas silicáticas identificadas no cemitério da Consolação.

Tabela 4. Distribuição dos padrões de deterioraçãoem função do tipo de rocha (carbonática ou silicática / silicosa).

Tabela 5. Objetos de estudo avaliados pelo uso da velocidade das ondas ultrassônicas e pelo uso do espectrofotômetro.

Tabela 6. Os valores da estatística descritiva aplicada aos parâmetros colorimétricos $L^{*}$, $a^{\star} e$ $b^{\star}$, em função da data e local estudado.

Tabela 7. Diferenças dos parâmetros colorimétricos $L^{*}, a^{*}, b^{*} e C^{*}$ e diferença total de cor $(\Delta E)$, para comparações entre os locais de estudo $A, B, C$ e $D$ para análises realizadas em uma mesma data.

Tabela 8. Diferenças dos parâmetros colorimétricos $L^{\star}, a^{*}, b^{\star} e C^{\star}$ e diferença total de cor $(\Delta E)$, para comparações das análises realizadas em datas diferentes, para uma mesmo local de estudo $(A, B, C$ ou $D)$.

Tabela 9. Valores obtidos para a avaliação realizada pela velocidade das ondas ultrassônicas.

Tabela 10. Os valores da estatística descritiva aplicada aos parâmetros colorimétricos $L^{*}, a^{*}$, $b^{\star}, C^{\star}$ e $H^{\circ}$ do Granito Itaquera para o túmulo da Família Pereira Pinto.

Tabela 11. Valores obtidos pelo método de transmissão direta.

Tabela 12. Os valores da estatística descritiva aplicada aos parâmetros colorimétricos $L^{*}, a^{*}$, $b^{\star}, C^{\star}$ e $H^{\circ}$, em função do local estudado, para a estátua Cristo do escultor Elio de Giusto. _ 70 Tabela 13. Diferenças dos parâmetros colorimétricos $L^{*}, a^{*}, b^{\star} e C^{*}$ e diferença total de cor $(\triangle E)$, para comparações entre os locais de estudo claros (LC), escuros (LE) e bem escuros (LBE), para análises realizadas em uma mesma data.

Tabela 14. Valores obtidos para a avaliação realizada pela velocidade das ondas ultrassônicas.

Tabela 15. Os valores da estatística descritiva aplicada aos parâmetros colorimétricos $L^{*}, a^{*}$, $b^{\star}, C^{\star}$ e $H^{\circ}$, em função do local estudado, para a estátua O Sepultamento de Victor Brecheret.

Tabela 16. Diferenças dos parâmetros colorimétricos $L^{*}, a^{\star}, b^{*} e C^{*}$ e diferença total de cor $(\Delta E)$, para comparações entre a frente da estátua $(F)$, costas da estátua $(C)$, costas da estátua com colonização biológica (CCB) e costas da estátua limpa (CL), para análises realizadas em uma mesma data.

Tabela 17. Valores obtidos para a avaliação realizada pela velocidade de propagação das ondas ultrassônicas. Estudo realizado no dia 03/04/2012.

Tabela 18. Valores da estatística descritiva aplicada aos parâmetros colorimétricos $L^{*}, a^{*}, b^{*}$, $C^{\star}$ e $H^{\circ}$, para a estátua Interrogação de Francisco Leopoldo e Silva.

Tabela 19. Diferenças dos parâmetros colorimétricos $L^{*}, a^{*}, b^{\star} e C^{*}$ e diferença total de cor $(\Delta E)$, para comparações entre as medidas realizadas em 30/07/2010 (TT1), 02/04/2012 (TT2) e 14/08/2012 (TT3), em todo o túmulo.

Tabela 20. Valores obtidos pelo método de transmissão direta._ 90

Tabela 21. Os valores da estatística descritiva aplicada aos parâmetros colorimétricos $L^{*}, a^{*}$, $b^{\star}, C^{\star}$ e $H^{\circ}$, em função do local estudado, para a Estátua Prece de Bruno Giorgi. ___ 91 Tabela 22.Diferenças dos parâmetros colorimétricos $L^{*}, a^{*}, b^{\star} e C^{*}$ e diferença total de cor $(\Delta E)$, para comparações entre a estátua e sua base de sustentação, para medidas realizadas em datas similares ou distintas.

Tabela 23. Valores obtidos para a avaliação realizada pela velocidade das ondas ultrassônicas.

Tabela 24.Os valores da estatística descritiva aplicada aos parâmetros colorimétricos $L^{*}, a^{*}, b^{*}$, $C^{\star}$ e $H^{\circ}$, em função do local estudado.

Tabela 25. Diferenças dos parâmetros colorimétricos $L^{*}, a^{*}, b^{*} e C^{*}$ e diferença total de cor $(\Delta E)$, para comparações entre a estátua e sua base retangular, para medidas realizadas em datas distintas.

Tabela 26. Valores obtidos pelo método de transmissão direta.___ 101

Tabela 27. Os valores da estatística descritiva aplicada aos parâmetros colorimétricos $L^{*}, a^{*}$,

$b^{\star}, C^{\star}$ e $H^{\circ}$, em função do local estudado, para o Túmulo da Marquesa de Santos. 102 
Tabela 28. Diferenças dos parâmetros colorimétricos $L^{*}, a^{*}, b^{\star} e C^{*}$ e diferença total de cor $(\Delta E)$, para comparações entre a estátua e sua base retangular, para medidas realizadas em datas distintas. 


\section{ÍNDICE DE EQUACÕES}

Equação 1. Croma.

Equação 2. Ângulo de tonalidade.

Equação 3. Diferença entre o padrão e a amostra para a luminosidade.

Equação 4. Diferença entre o padrão e a amostra para a cromacidade a.

41

Equação 5. Diferença entre o padrão e a amostra para a cromacidade $b$.

Equação 6. Diferença total da cor.

Equação 7. Diferença entre o padrão e a amostra para o croma. 42

Equação 8. Expressão para o cálculo da velocidade de propagação das ondas ultrassônicas. 
AGRADECIMENTOS__ v

RESUMO _ vii

ABSTRACT_ ix

ÍNDICE DE FIGURAS __ Xi

ÍNDICE DE TABELAS___ XVi

1. INTRODUÇÃO__ 1

2. OBJETIVOS 2

3. JUSTIFICATIVA 3

4. LOCALIZAÇÃO E ACESSOS __ 3

5. MATERIAIS E MÉTODOS__ 4

5.1. BIBLIOGRAFIA E ICONOGRAFIA HISTÓRICA DO CEMITÉRIO DA CONSOLAÇÃO, SÃO PAULO 4

5.2. CONSTITUIÇÃO PÉTREA DO CEMITÉRIO DA CONSOLAÇÃO ___ 5

5.3. PADRÕES DE DETERIORAÇÃO DASROCHAS _ 5

5.4. VELOCIDADE DE PROPAGAÇÃO DAS ONDAS ULTRASSÔNICAS___ 5

5.5. COLORIMETRIA _ 6

6. AS NECRÓPOLES MAIS FAMOSAS DO MUNDO__ 7

6.1. HISTORIOGRAFIA DO CEMITÉRIO DA CONSOLAÇÃO, SÃO PAULO _ 9

6.2. ICONOGRAFIA E ICONOLOGIA DO CEMITÉRIO DA CONSOLAÇÃO, SÃO PAULO

7. MÉTODOS NÃO DESTRUTIVOS UTILIZADOS NO ESTUDO DOS MONUMENTOS PÉTREOS

7.1. DETERMINAÇÃO DOS MATERIAIS GEOLÓGICOS EXISTENTES NO CEMITÉRIO DA CONSOLAÇÃO

7.2. MAPEAMENTO DOS PADRÕES DE DETERIORAÇÃO DA ROCHA

7.3. COLORIMETRIA E VELOCIDADE DE PROPAGAÇÃO DAS ONDAS ULTRASSÔNICAS

7.3.1. FUNDAMENTOS DA COLORIMETRIA 39

7.3.2. FUNDAMENTOS DA PROPAGAÇÃO DAS ONDAS ULTRASSÔNICAS _— 46

7.3.3. DETERMINAÇÃO DO ESTADO DE DETERIORAÇÃO UTILIZANDO

COLORIMETRIA E PROPAGAÇÃO DAS ONDAS ULTRASSÔNICAS __ 49

7.3.3.1. Túmulo da Família Pereira Pinto (1868-1886)___ 62

7.3.3.2. Estátua Cristo (1962) - Escultor Elio de Giusto___ 67

7.3.3.3. Estátua O Sepultamento (1923) - Escultor Victor Brecheret

7.3.3.4. Estátua Interrogação (1923) - Escultor Francisco Leopoldo e Silva__ 83

7.3.3.5. Estátua Prece (1945) - Escultor Bruno Giorgi____ 88

7.3.3.6. Túmulo de Luisa Crema Marzorati (1922) ___ 94

7.3.3.7. Túmulo da Marquesa de Santos (1867)

8. MECANISMOS DE DEGRADAÇÃO _ 105

8.1. NATUREZA LITOLÓGICA__ 105 
8.2. INTERAÇÃO DE MATERIAIS

8.3. POLUIÇÃO ATMOSFÉRICA

8.4. COLONIZAÇÃO BIOLÓGICA

8.5. CONDIÇÕES CLIMÁTICAS

8.6. CARACTERÍSTICAS ARQUITETÔNICAS 115

8.7. VANDALISMO 116

8.8. FALTA DE GERENCIAMENTO 120

8.8.1. Mausoléu da Família Matarazzo

8.8.2. Mausoléu da Família Siciliano

8.9. MÉTODOS INADEQUADOS DE CONSERVAÇÃO E RESTAURO 130

9. AÇÕES DE CONSERVAÇÃO 135

10. CONCLUSÕES 136

11. REFERÊNCIAS BIBLIOGRÁFICAS 138

\section{ANEXOS}

Anexo 1. Valores dos dados obtidos com o aparelho de ultrassom.

Anexo 2. Reportagem da Folha de São Paulo intitulada Cemitério da Consolação registra aumento no número de furtos.

Anexo 3. Reportagem da Folha de São Paulo intitulada Homem é preso por furto no cemitério da Consolação, em SP.

Anexo 4. Reportagem da Folha de São Paulo intitulada Prefeitura vai instalar câmeras nos cemitérios de SP.

Anexo 5. Reportagem da Folha de São Paulo intitulada Uma sanfona para São Paulo.

Anexo 6. Guia das Práticas Adequadas a Conservação dos Cemitérios Franceses.

Anexo 7. Guia de Visitação do Cemitério da Consolação. 


\section{INTRODUÇÃO}

Ao analisarmos a vida dos primeiros povos verificamos o grande respeito e veneração pelos mortos, que se traduziu não só nos ritos religiosos, como na tentativa de preservação memorial pela inumação (Araújo, 2006).

O desejo de perpetuar a memória dos antepassados é um impulso primitivo e fundamental, que nos últimos tempos está perdendo seu poder de envolver o homem na criação e cuidados pelos seus monumentos de pedra. A maioria dos túmulos honra grandes homens, mas por volta dos séculos XVII e XVIII, também os humildes, assim como os ricos e poderosos, comemoravam a vida e a fé na vida eterna pela construção de um memorial, feito de pedra natural por um artesão local (Burgess, 2004).

As civilizações ao longo dos séculos desenvolveram diversas maneiras de cultuar seus mortos, justamente por acharem que a força motora que movia o corpo não poderia desaparecer sem nenhuma razão. Entenderam que o defunto passava para outro estágio de vivência, continuando a ter necessidades após a morte. Em função disso, além de procurarem preservar os restos mortais, colocavam junto dele os apetrechos dos quais ele mais gostava e faziam oferendas fúnebres, depositando sobre o túmulo comida e bebida (Araújo, 2006).

Para acomodar as oferendas de pessoas com grande prestígio social, era comum construir suntuosas tumbas, ricamente ornamentadas e com descrições dos seus atos heroicos em vida. Essas tumbas, muito difundidas na sociedade egípcia, deveriam estar à altura do seu ilustre hóspede e transmitir seu status de poder pela eternidade.

O Cemitério da Consolação, fundado em 1858, foi o primeiro cemitério municipal da cidade de São Paulo. Concebido em uma época de profunda mudança, tornou-se o testemunho da história da monarquia e da república brasileira, assim como da elite cafeicultora paulista e dos imigrantes que fizeram a América (Timpanaro, 2006).

Abriga inúmeras muitas personalidades, como a Marquesa de Santos, Conde Francesco Matarazzo, Campos Sales, Washington Luís, Monteiro Lobato, Oswald de Andrade, Mário de Andrade, Tarsila do Amaral, Ramos de Azevedo, entre outros. Seus túmulos, muitas vezes, ricamente ornamentados por artistas conceituados como Victor Brecheret, Francisco Leopoldo e Silva, Nicola Rollo, Luigi Brizzolara e Galileo Emendabili, constituem verdadeiras obras de arte, tornando o Cemitério da Consolação um museu a céu aberto.

Muitas dos túmulos apresentam processos de deterioração que comprometem sua integridade. O estudo proposto consiste em avaliar o estado de conservação do Cemitério da Consolação, abrangendo túmulos e estruturas de significativa importância cultural. Foram utilizados métodos não destrutivos de investigação in situ, que compreenderam o 
mapeamento dos padrões de deterioração da rocha, análise das velocidades de propagação das ondas ultrassônicas, e determinação da modificação da cor da rocha pelo uso do espectrofotômetro. A partir da realização dos diagnósticos foi possível identificar vários mecanismos de degradação, o que auxiliará futuros trabalhos de restauração.

Além do estudo do estado de conservação, foi dada ênfase a difusão da importância cultural do Cemitério da Consolação, visto que para bem restaurar e conservar um monumento é necessário, acima de tudo, amá-lo e entendê-lo (Boito, 1884).

\section{OBJETIVOS}

O presente estudo propõe avaliar o estado de conservação do Cemitério da Consolação, objetivando a obtenção das seguintes informações:

- Justificar a importância da conservação do objeto de análise, a partir do estudo bibliográfico e iconográfico da necrópole;

- Identificar os litotipos que constituem os jazigos e outras estruturas existentes;

- Determinar os padrões de deterioração da rocha, e quais predominam em cada litotipo estudado;

- Avaliar modificações nas cores das rochas de alguns jazigos, pela comparação de zonas de aspecto íntegro com zonas deterioradas e pela análise periódica de um mesmo local a partir de análises espectrofotométricas;

- Determinar locais, em alguns jazigos, com maior grau de alteração e com falta de homogeneidade da rocha, a partir de análises com o ultrassom.

- Determinar os mecanismos de degradação existentes no Cemitério da Consolação;

- Avaliar a adequação da metodologia proposta para o estudo da degradação de monumentos pétreos.

Como objetivo secundário, mas não menos importante, citar algumas políticas de conservação para cemitérios, algo muito comum em países europeus. Como parte dessa ação, incentivar a exploração turística da necrópole, à semelhança doque ocorre no Cemitério Père Lachaise em Paris e no Cemitério da Recoleta em Buenos Aires. 


\section{JUSTIFICATIVA}

Ocemitério é considerado uma fonte histórica extremamente importante no que diz respeito à história arqueológica, material e social de uma civilização (Daniels, 2006). Bellomo (2000) também atribui grande importância histórica às necrópoles, destacando-as como: principal fonte de preservação da memória familiar e coletiva; fonte de estudo das crenças religiosas; forma de expressão do gosto artístico; forma de expressão da ideologia política; forma de preservação do patrimônio histórico; fonte para conhecer a formação étnica;fonte para o estudo da genealogia; e fonte reveladora da perspectiva de vida.

Há um século a relação da sociedade com seus mortos era diferente, a manutenção da memória do falecido para a comoção e, é claro, para ser admirada por todos, perdeu o sentido na medida em que os costumes foram mudando. Atualmente é muito difícil proteger um cemitério, principalmente com população deixando de visitá-lo e, em muitos casos, criando preconceitos. Timpanaro (2006) defende que se a população de uma cidade não se sensibilizar pelos seus monumentos, eles estão fadados ao esquecimento e posteriormente à destruição.

Desta forma é importante encontrar maneiras de se conservar o Cemitério da Consolação, preservando não somente o seu acervo artístico, mas também a memória das grandes personalidades sepultadas no seu interior, cujos nomes, ações e pensamentos devem sobreviver para transmitir a identidade do povo brasileiro.

\section{LOCALIZAÇÃO E ACESSOS}

Localizado próximo ao centro de São Paulo, Capital (Figura 1), o acesso principal ao cemitério é pela rua da Consolação, 1.660, sendo delimitado pelas ruas Mato Grosso, Sergipe e Coronel José Eusébio, além dos cemitérios dos Protestantes e da Ordem Terceira do Carmo. Aberto todos os dias das $7 \mathrm{~h}$ às $18 \mathrm{~h}$, com entrada gratuita, possui uma área de $77.0000 \mathrm{~m}^{2}$, ocupada por cerca de 8.000 jazigos. 


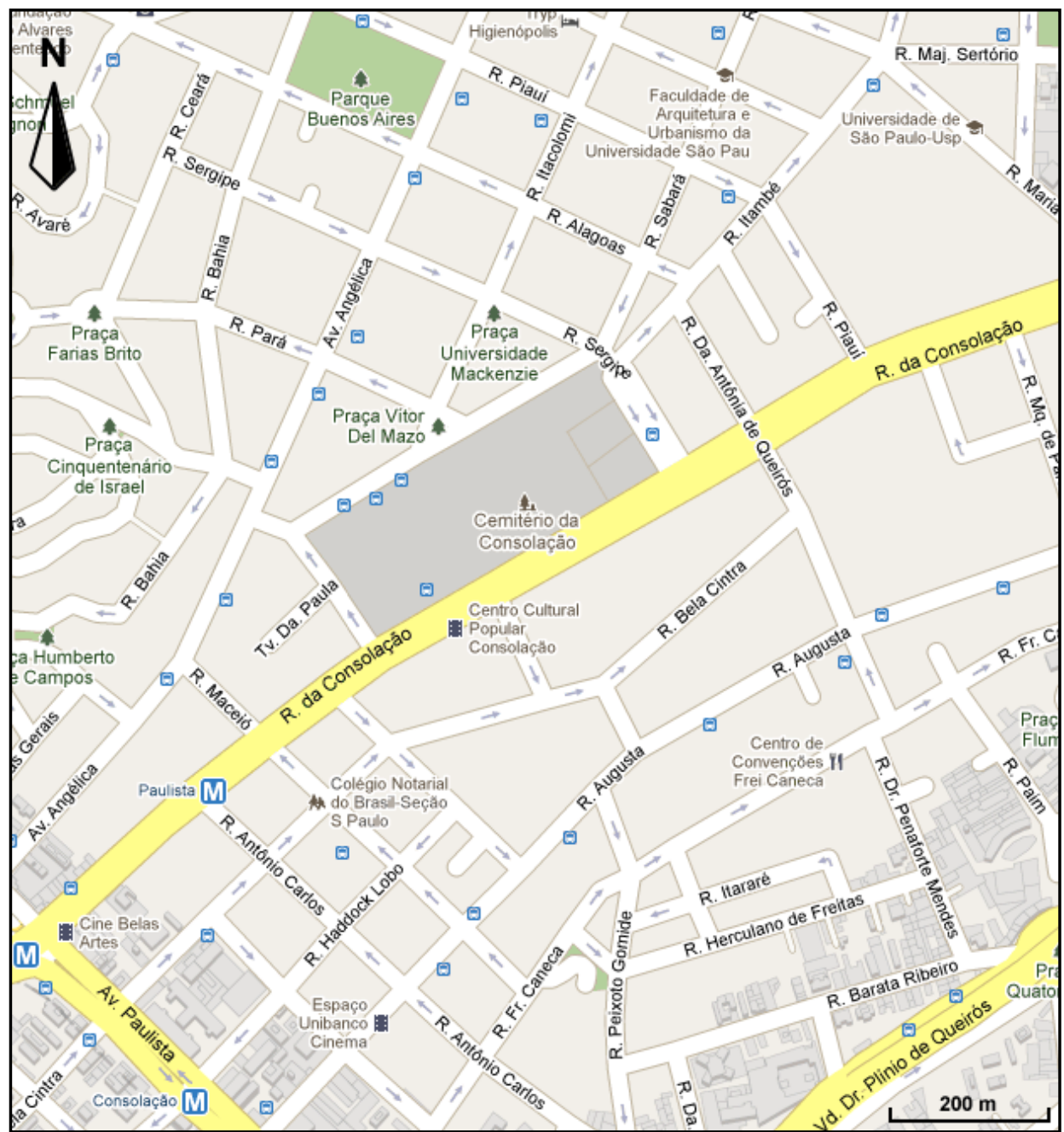

Figura 1.Localização do Cemitério da Consolação, São Paulo - SP.

Fonte: Modificado de http://maps.google.com.br (Google Maps).

\section{MATERIAIS E MÉTODOS}

Para a avaliação do estado de conservação do Cemitério da Consolação foi seguida a metodologia de investigação proposta por Fitzner (2004), que abrange os materiais e métodos descritos a seguir.

\subsection{BIBLIOGRAFIA E ICONOGRAFIA HISTÓRICA DO CEMITÉRIO DA CONSOLAÇÃO, SÃO PAULO}

O estudo bibliográfico e iconográfico histórico envolveu a compilação e avaliação de informações para contextualizar e sensibilizar a importância da conservação do Cemitério da Consolação. 
A consulta bibliográfica envolveu a busca pelas seguintes informações: histórico daconstrução do cemitério e seu desenvolvimento ao longo do tempo; quais os partidos arquitetônicos presentes; quais os roteiros devisitação existentes; qual a proveniência dos materiais utilizados na construção dos túmulos e na infraestrutura; as modificações que ocorreram nos jazigos e na necrópole; ea existência de políticas de conservação. Para tanto foi consultado o arquivo de tombamento do cemitério no CONDEPHAAT (Conselho de Defesa do Patrimônio Histórico, Arqueológico, Artístico e Turístico), a bibliografia existente no Arquivo Histórico de São Paulo, além de teses, dissertações e livros que abrangem esta temática, onde o estudo realizado por Valladares (1972) destaca-se, por ser o primeiro trabalho direcionado ao estudo do patrimônio cemiterial brasileiro, incluindo informações a respeito do Cemitério da Consolação.

A busca iconográfica foi realizada nos acervos fotográficos do Arquivo Histórico de São Paulo e da Casa da Imagem de São Paulo, além das fotografias presentes em Valladares (1972) e na revista A Cigarra, impressa na cidade de São Paulo entre 1914 e 1975, disponível digitalmente no Arquivo Publico do Estado de São Paulo.

\subsection{CONSTITUIÇÃO PÉTREA DO CEMITÉRIO DA CONSOLAÇÃO}

A caracterização petrográfica dos jazigos do Cemitério da Consolação foi realizada pela análise macroscópica dos litotiposin situ, com auxílio de lupa de mão. Os nomes comerciais foram determinados a partir da identificação visual dos litotipos em catálogos de rochas ornamentais (IPT, 1990; Abirochas, 2012) e em sites de empresas especializadas nesses materiais geológicos (Magma Stone, 2012; Marmoraria Tamoios, 2012; Pedras Ipiranga, 2012).

\subsection{PADRÕES DE DETERIORAÇÃO DASROCHAS}

Para a classificação dos padrões de deterioração da rocha, foi utilizado o atlas proposto pelo ICOMOS (2008).

\subsection{VELOCIDADE DE PROPAGAÇÃO DAS ONDAS ULTRASSÔNICAS}

A determinação dostempos de propagação das ondas ultrassônicas foi realizada com o aparelho de ultrassom VMeter III da James Instruments Inc (Figuras 2 e 3), utilizando transdutores planos de $54 \mathrm{kHz}$ (Emissor e receptor com diâmetro de $5 \mathrm{~cm}$ ) e $150 \mathrm{kHz}$ 
(Emissor e receptor com diâmetro de 2,2 cm). Para acoplagem entre os transdutores e os objetos de estudo foi utilizado gel para ultrassom, produto não gorduroso e hidrossolúvel, composto por polímero carboxivinílico, propilenoglicol, trietanolamina, conservante e água purificada.

A determinação da distância de propagação da onda ultrassônica foi realizada com o auxílio de trena de precisão, com graduação em milímetro e milímetro/polegada, e para locais com dimensões irregulares, as medidas foram realizadas com auxilio de compasso externo, com as medidas transmitidas posteriormente a trena de precisão.

A técnica utilizada foi a da transmissão, com o posicionamento do transdutor $\mathrm{e}$ receptor, no objeto de estudo, realizado com base na norma ABNT NBR 8802/94, consistindo: transmissão direta (transdutores alinhados de maneira oposta na face do objeto de estudo), tramissão semidireta (transdutores alinhados perpendicularmente entre si), transmissão indireta (transdutores alinhados em uma mesma face do objeto de estudo).

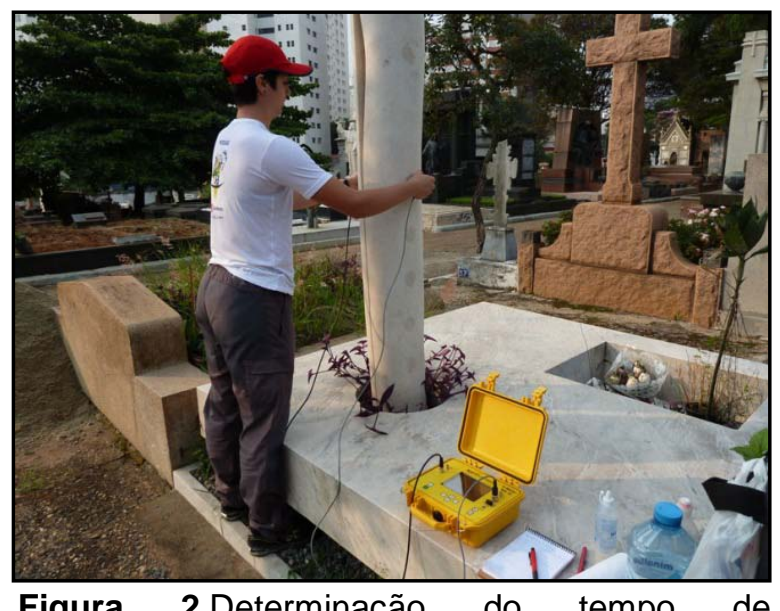

Figura 2.Determinação do tempo de propagação das ondas ultrassônicas na estátua de mármore. Método de transmissão direta.

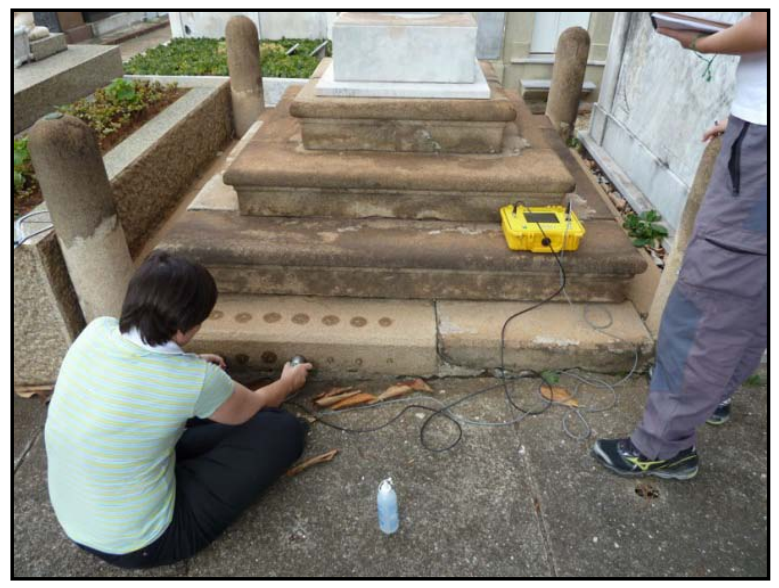

Figura 3.Determinação do tempo de propagação das ondas ultrassônicas no túmulo em granito. Método de transmissão indireta.

\subsection{COLORIMETRIA}

Para a realização das medidas colorimétricas, foi utilizado o espectrofotômetro Konica Minolta 2500d (Figuras 4 e 5) com abertura de 8 mm, fonte de iluminação D65, incluindo região ultravioleta do espectro, componente especular inclusa (SCI) e exclusa (SCE) e ângulo de observação de $10^{\circ}$. As medidas foram expressas nos espaços de cor CIELAB e CIELCh, ambos da CIE (Commission Internationale de I'Eclairage - Comissão Internacional de Iluminação), com o tratamento dos dados realizado nos softwares OnColor version 5.4.5.1 e Microsoft Excel 2002 (Versão 10.0). 


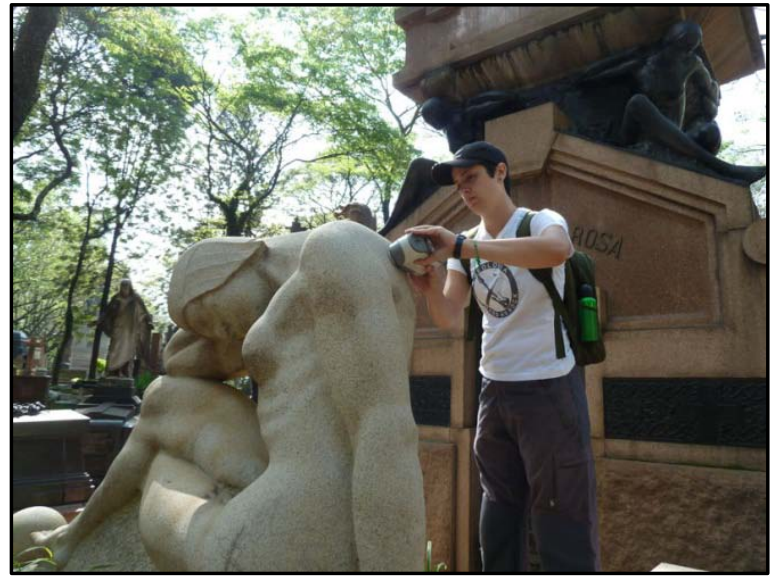

Figura 4. Determinação dos parâmetros colorimétricos da estátua em granito, utilizando o espectrofotômetro.

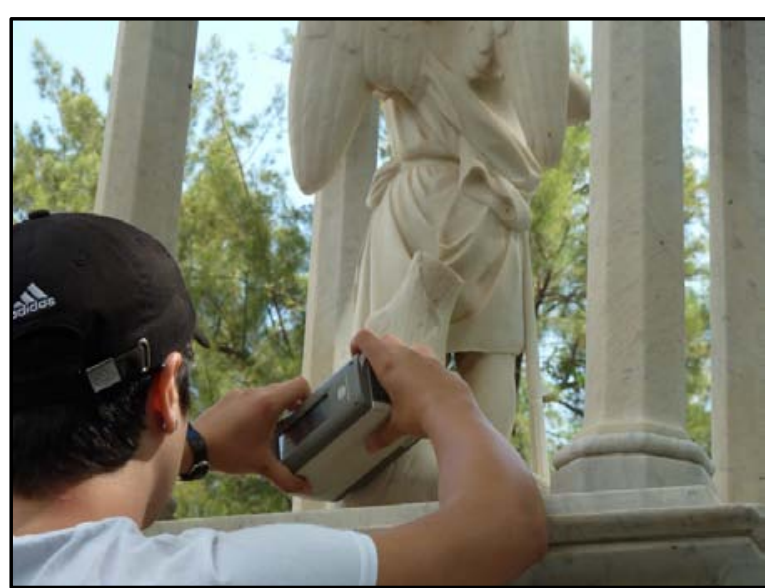

Figura 5. Determinação dos parâmetros colorimétricos da estátua em mármore, utilizando o espectrofotômetro.

\section{AS NECRÓPOLES MAIS FAMOSAS DO MUNDO}

Muitos cemitérios espalhados pelo mundo atraem visitantes, não apenas familiares e amigos que vão prestar homenagem ao defunto, mas turistas interessados em admirar esculturas e mausoléus, que são reconhecidas obras de arte, ou em visitar sepulturas de figuras célebres do mundo das artes, das letras e da política. Entre os cemitérios mais visitados estão os franceses Père Lachaise, Montparnasse e Montmartre, os ingleses Highgate e Golders Green Crematorium. Na América do Sul, o Cemitério La Recoleta, em Buenos Aires, Argentina, é o mais conhecido internacionalmente, seguido pelos brasileiros, localizados em São Paulo, Cemitério da Consolação, Cemitério do Morumbi, Cemitério São Paulo e Cemitério do Araçá, e o localizado no Rio de Janeiro, Cemitério São João Batista.

Os cemitérios mais famosos do mundo, segundo a Revista Forbes (2009) são:

- Cemitério Nacional de Arlington - Arlington, EUA: mais conhecido e tradicional cemitério militar norte americano, onde estão sepultados veteranos de cada uma das guerras travadas pelo país, desde a revolução americana até a Guerra do Iraque. Entre os túmulos está o do ex-presidente John F. Kennedy.

- Trinity Churchyard - Nova York, EUA: composto por três cemitérios separados, associados à Igreja Trinity, em Manhattan, abrange o Cemitério de Intercessão, onde há placas comemorativas da Batalha de Fort Washington, um dos mais violentos combates da Guerra Revolucionária. 
- Cemitério Boot Hill - Tombstone, Arizona, EUA: no século XIX o nome Boot Hill ou Boothill era atribuído aos cemitérios do oeste americano, onde eram sepultados pistoleiros ou pessoas que tiveram morte violenta. Nele estão os túmulos de Billy Clanton, Frank McLaury e McLaury Tom, os três homens mortos durante tiroteio no famoso O.K.Corral.

- Hollywood Forever - Hollywood, EUA: localizado em Santa Monica Boulevard, Hollywood, distrito de Los Angeles, Califórnia, foi fundado em 1899, com o nome de Hollywood Memorial Park. No final do século XX estava bastante deteriorado e em processo de falência, quando foi adquirido pela empresa Tyler Cassity, que o recuperou e o renomeou como Hollywood Forever. No local estão enterradas celebridades da indústria de entretenimento norte-americana.

- Mt. Auburn - Cambridge, EUA: construído baseando-se no modelo dos cemitérios franceses, foi o primeiro desse tipo construído nos EUA. Bastante arborizado, lá estão enterrados escritores e pensadores como Buckminster Fuller e Henry Wadsworth Longfellow.

- St. Louis - Nova Orleans, EUA: fundado em 1789, consiste de um modo diferente de se enterrar os falecidos. Cada um dos 100 mil mortos que ali jazem, foram enterrados em um túmulo com traços arquitetônicos de uma habitação.

- Père Lachaise - Paris, França: cemitério mais famoso da França, nos seus 500 mil $\mathrm{m}^{2}$ estão sepultadas muitas celebridades, como Oscar Wilde, Edith Piaf, Honoré de Balzac, Marcel Proust, Alice B. Toklas, Richard Wright, Jim Morrison entre outros. Representa a transição dos cemitérios com jardins para o cemitério urbanizado.

- Cemitério Old Jewish - Praga, República Tcheca: cemitério judeu datado do século XV, com aproximadamente 12 mil sepulturas, é o que apresenta maior número de defuntos por área quadrada. Sem espaço para enterrar seus mortos, os judeus se viram obrigados a sobrepor lápides, umas às outras. Nele está enterrado o escritor Franz Kafka.

- San Michele - Veneza, Itália: situado numa ilha a poucos minutos de Veneza, é apelidado de Ilha dos Mortos. É um lugar procurado por quem está atrás de 
reclusão, paz e tranquilidade. Nele estão os túmulos de Ezra Pound, Igor Stravinsky e Joseph Brodsky.

- La Recoleta - Buenos Aires, Argentina: cemitério mais famoso da América Latina atrai muitos turistas que desejam visitar o túmulo de Eva Perón, expresidentes argentinos, atores, militares e outras personalidades. A estrutura do cemitério se compõe de ruas, avenidas e até praças, possuindo muitas estátuas em mármore, criptas senhoriais e inclusive alguns sarcófagos abertos.

A Associação dos Cemitérios Significativos da Europa (ASCE) é uma organização europeia sem fins lucrativos, com apoio de empresas públicas e privadas, que zela pelos cemitérios que apresentam importância histórica e artística na Europa, abrangendo 179 necrópoles distribuídas em 22 países. Entre os objetivos da organização está a promoção dos cemitérios Europeus como parte fundamental do patrimônio da humanidade, sensibilizando as pessoas da sua importância para manutenção da cultura europeia e garantindo a proteção desses espaços. Cerca de 60 cemitérios, localizados em 45 cidades de 18 países diferentes, estãoincluídos na Rota dos Cemitérios Europeus (European Cemeteries Route, 2010), que recebe aproximadamente 5 milhões de visitantes por ano.

\subsection{HISTORIOGRAFIA DO CEMITÉRIO DA CONSOLAÇÃO, SÃO PAULO}

A história do primeiro cemitério municipal da cidade de São Paulo, tempos depois chamado de Cemitério da Consolação, é muito mais antiga do que a data da sua inauguração, ocorrida no dia 15 de agosto de 1858, remonta a $1^{\circ}$ de outubro de 1828 , quando foi promulgada uma lei que proibia os sepultamentos nas igrejas e enfatizava que os cemitérios deveriam ser construídos afastados da cidade, a fim de que a população não tivesse contato com os miasmas pútridos (mau cheiro) produzidos pelos cadáveres.

O grande problema relacionado com a construção de cemitérios na cidade de São Paulo era os interesses opostos entre a Igreja Católica e os liberais republicanos. Até então, a prática vigente preconizava que os cadáveres deveriam ser sepultados no interior dos templos, o que trazia ganhos econômicos a Igreja (grande parte do seu patrimônio foi formado a partir de doações de terrenos ou construções de templos em troca de sepulturas no altar) além de manter odomínio psicológicoda população (sepultamentos fora das igrejas eram associados com a condenação do indivíduo ao inferno, enquanto sepultamentos no seu interior representavam a salvação e a vida eterna). 
Os liberais, ao contrário, queriam laicizar o espaço e promover o fim das superstições e crenças cultivadas pela Igreja, em nome do progresso e do racionalismo científico. Para isso, a estratégia utilizada foi o higienismo, que argumentava que as constantes epidemias na cidade de São Paulo eram associadas aos miasmas pútridos, frequentes no interior das igrejas.

Nesse contexto, na sessão da Câmara do dia 21 de março de 1829, o vereador Joaquim Antonio Alves Alvim coloca em discussão a proibição dos sepultamentos nas igrejas e a construção de um cemitério público geral na cidade de São Paulo. Inicialmente foi proposto que o cemitério fosse construído ao lado da Igreja da Consolação, entretanto devido àdificuldade de negociação das terras, foi sugerido um novo local, um terreno pertencente àlgreja da Luz, mas fácil de conseguir por ser de propriedade eclesiástica.

Após três anossem nenhuma decisão tomada, o tema volta a ser discutido no âmbito da Câmara Municipal, com a sugestão de se construir o cemitério geral na atual região dos Campos Elíseos (na época chamada de Campo Redondo).

Vários protestos ocorreram contra essa iniciativa da Câmara, sendo que a principal justificativa foi dada pelo engenheiro Carlos Frederico Rath, que visando os interesses de Frederico Glete e Victor Nothman, que queriam lotear a área e vendê-la aos fazendeiros do café, escreveu um extenso memorial contra a decisão da Câmara, mostrando as várias inconveniências de um cemitério naquela região, principalmente porque o bairro era muito povoado.

Sugeriu então, que o local mais apropriado seria o alto da Consolação, lugar afastado da cidade e sem moradores. Na verdade, essa escolha foi um paradoxo, pois segundo os argumentos dos higienistas, os miasmas pútridos eram transmitidos pelo ar e os cadáveres depositados em tal local, com grande incidência de ventos, facilitariam a disseminação dos miasmas para os lugares mais baixos. Assim, parte da população percebeu que o discurso higienista não estava sendo aplicado na prática, pois a escolha do local fugiu aos padrões da saúde pública e serviu para os interesses do grupo de loteadores.

Apesar de abaixo-assinados feitos por parte da população, principalmente referente à localização que obrigava as pessoas a dar uma volta desnecessária para chegar ao cemitério, a sugestão do Doutor Rath foi aceita e no mesmo ano de 1855, o Cemitério da Consolação começou a ser construído.

No local escolhido, parte das terras era de domínio público, nas margens da antiga estrada dos Pinheiros, e parte pertencia a Marciano Pires de Oliveira, proprietário de uma grande chácara no local. Na mesma época, Domitila de Castro Canto e Melo, mais conhecida como Marquesa de Santos, doou a quantia de 2 Contos de Réis (uma pequena fortuna para época), para ser utilizada exclusivamente na construção da primeira capela do cemitério (Serviço Funerário de São Paulo, 2010a). 
Finalmente em 15 de agosto de 1858 o Cemitério Público Geral foi inaugurado, devido, em grande parte, a uma epidemia de varíola que se espalhou pela capital. Posteriormente, em 1883e 1889, a Câmara desapropriaria áreas pertencentes respectivamente ao Conselheiro Ramalho e a Joaquim Floriano Wanderley para aumentar a área do cemitério, o qual estava com problemas de superlotação. Em 1891, o total de mortos ali sepultados já chegava a 480 por mês; o cemitério estava cheio novamente, o que colaborou com a construção de novos cemitérios. Em 1893 foi inaugurado o Cemitério do Brás ou da $4^{a}$ Paradae em 1897 o Cemitério do Araçá.

Inicialmente eram sepultadas pessoas de todas as classes sociais. Com a construção das duas novas necrópoles, o Cemitério da Consolação iniciou um processo de elitização, que mudou não somente o perfil dos sepultados, mas também, e principalmente, os estilos das sepulturas e os materiais utilizados. Enquanto até o final do século XIX somente as personalidades brasileiras tinham os jazigos ornamentados, principalmente por mármore importado, nas primeiras décadas do século $X X$, o cemitério foi invadido por sepultamentos de famílias árabes e italianas, com a substituição do mármore por granitos e por estatuária de bronze (Valladares, 1972). Este período ficou conhecido com a Belle Époque paulistana e a elite para firmar status, passou a promover a ideia que aquele que realizou em vida algo de relevante para sociedade, deveria ter uma morada à altura de sua importância social, como meio de evidenciar a sua superioridade perante os outros. Por este motivo, a partir da primeira década do século $X X$, familiares e amigos contratavam construtores e escultores de renome, em sua maioria de origem italiana ou com formação na Europa, como Victor Brecheret, Luigi Brizzolara, Galileo Emendabili, Nicola Rollo, entre outros, para construírem e ornamentarem os túmulos das ilustres personalidades. Em 1901, o vereador José Oswald Nogueira de Andrade (pai do escritor Oswald de Andrade), não satisfeito com a aparência do cemitério, que segundo o mesmo não coaduna com a moradia dos mortos de uma cidade como São Paulo, propugnou pela completa reconstrução dos muros, da capela edo pórtico de entrada, sendo o projeto contratado com o arquiteto Ramos de Azevedo.

Foi a partir desse momento que o Cemitério da Consolação começou a adquirir toda a sua galeria de arte. Atualmente conta com mausoléus neoclássicos que datam da década de 1870, mausoléus realistas que exploravam a figuração individual e familiar (na maioria dos casos projetando também símbolos nobiliárquicos que datam de meados da década de 1890), mausoléus românticos na sua maioria provenientes da Europa, e mausoléus inspirados na art-noveau, onde a sensualidade e o apreço pelo corpo em estado de êxtase e desolação são as principais representações. Cabe lembrar dos modernistas que deixaram as suas marcas em meados da década de 1920.

O Cemitério da Consolação não foi utilizado somente para o sepultamento da rica elite paulistana e de ateliê para inúmeros artistas. Os escritores Oswald de Andrade e Patrícia 
Galvão, a Pagú, pertencentes ao movimento modernista se casaram em cerimônia simbólica em frente do túmulo da família de Oswald no início da década de 1930.

Atualmente, o Cemitério da Consolação abriga um dos mais importantes acervos culturais da cidade de São Paulo. Com seus túmulos ricamente ornamentados, essa necrópole é o testemunho vivo de importantes fatos da história social de São Paulo e do Brasil, trazendo ao nosso conhecimento, representantes importantes da vida política e cultural, seus feitos e a repercussão na cidade. Da mesma forma temos na necrópole muitas informações que inevitavelmente provocam a reflexão sobre a construção da cidade, dos novos hábitos da população, suas complexidades e disparidades verificadas atualmente. Se num primeiro momento a intenção era proteger os vivos dos mortos e de seus miasmas em meados do século XIX, atualmente os muros protegem os mortos dos vivos em vários sentidos: da depredação constante que sofrem os túmulos, seja pelo roubo de placas de bronze ou da quebra de seus monumentos; do espaço do cemitério como local de pernoite; das pichações; ou ainda como forma de proteger esse espaço das constantes transformações pela qual a cidade passa, preservando ali diferentes tempos históricos (Timpanaro, 2006).

Um dos primeiros problemas relacionados à conservação do cemitério ocorreu em 1974, quando a Prefeitura de São Paulo, através de decreto assinado pelo então prefeito Miguel Colassuono, decretou caducidade de 212 sepulturas do Cemitério da Consolação, entre elas a da Marquesa de Santos e do educador Carlos de Campos.

Segundo esse decreto, os túmulos seriam desocupados e os restos mortais de seus ocupantes retirados e enterrados em valas comuns, sendo os terrenos vazios revendidos a interessados, com a condição de que fossem utilizados para sepultamentos imediatos.

No entanto, o CONDEPHAAT interveio na situação declarando que as sepulturas não poderiam ser demolidas ou modificadas e seus restos mortais não poderiam ser tocados, alegando ser de competência dessa instituição, segundo a constituição federal e estadual, zelar pelo patrimônio histórico e artístico do Estado de São Paulo.

A prefeitura teve que voltar atrás na sua decisão, até para evitar maiores problemas com entidades, associações e os familiares dos mortos, que protestaram contra a medida (mortos ilustres são protegidos pela legislação municipal, artigo 122, ato 326, de 1932, que determina que tenham eles seus túmulos zelados pela Prefeitura. Também segundo o Documento de Brasília de abril de 1970: Urge legislação defensiva dos antigos cemitérios e especialmente dos túmulos históricos e artísticos e monumentos funerários).

Em 19 de abril de 1974 os jornais publicaram que a prefeitura não mais cassaria a concessão dos 212 túmulos, declarando-os de utilidade pública. O prefeito Miguel Colassuono assinaria decretos dispondo sobre a eliminação da decisão anterior e a preservação dos túmulos de pessoas ilustres. 
Apesar dos problemas relacionados à conservação do cemitério terem se iniciado na década de 1970, o seu tombamento ocorreu somente em 2005, segundo a resolução SC 28/05, de 28 de junho de 2005, publicado no DOE 09/07/05, p. 35, que diz:

Ficam tombados como bens culturais de interesse artístico, urbanístico, paisagístico, histórico e turístico os Cemitérios da Consolação, da Ordem Terceira do Carmo e dos Protestantes, que ocupam inteiramente a quadra definida pela rua da Consolação, José Eusébio, Mato Grosso e Sergipe, incluindo as calçadas e o conjunto arbóreo em torno dessa quadra.

\subsection{ICONOGRAFIA E ICONOLOGIA DO CEMITÉRIO DA CONSOLAÇÃO, SÃO PAULO}

Ao pensar sobre a evolução do Cemitério da Consolação ao longo do tempo, seria ingenuidade acreditar que não ocorrem mudanças no seu interior. Os cemitérios são espaços de dinâmica própria, de tempo próprio e, por isso, distante das transformações sentidas em toda a cidade (Timpanaro, 2006). A iconografia (linguagem visual que expressa por meio de imagens um determinado tema) e a iconologia (atribuição de significado à representação contida na imagem) foram as ferramentas utilizadas para identificar as modificações no meio físico e construído do cemitério, colaborando na identificação dos mecanismos de deterioração existentes.

As Figuras 6 e 7 retratam o Cemitério da Consolação em dois tempos distintos, mostrando claramente as modificações sofridas pelo acesso principal do cemitério, no intervalo de tempo de quase um século. Comparando-as notam-se modificações nos jardins laterais que levam a capela, com a inserção da mureta e o plantio de arbustos adjacentes às árvores existentes. O calçamento também foi modificado pela colocação deparalelepípedos. Se levarmos em consideração apenas o crescimento das árvores, é possível concluir que ocorrem modificações na insolação, exposição à chuva e aos ataquesde micro-organismos dos túmulos e construções próximas. 


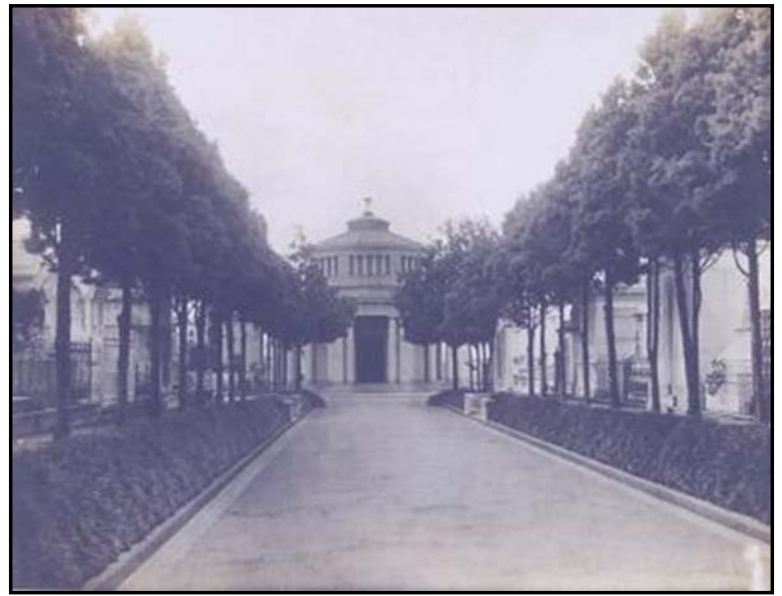

Figura 6. Entrada principal do Cemitério da Consolação em 1916.

Fonte: Desconhecida.

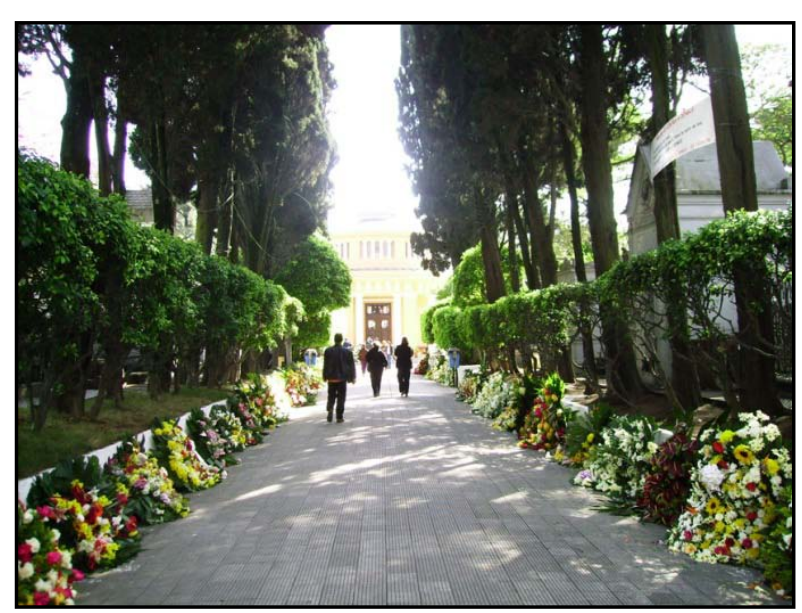

Figura 7. Entrada principal do cemitério da Consolação, ao fundo a capela. Fotografado em 26 de junho de 2008, dia do enterro da ex-primeira dama Ruth Cardoso.

A historiografia do Cemitério da Consolação revela que a primeira modificação significativa ocorreu devido à revitalização da necrópole em 1901. Essa modificação envolveu a demolição dacapela, construída graças à doação deixada em testamento pela Marquesa de Santos, e dos muros que circundavam a área do cemitério, acabando com os registros das características arquitetônicas, técnicas construtivas e materiais empregados nas construções do século XIX.

A fotografia atribuída ao fotógrafo histórico Militão Augusto de Azevedo (Figura 8) é a referência iconográfica mais importante do Cemitério da Consolação no século XIX. Nela está representada a primeira capela do cemitério, notando-se também a pobre ornamentação dos túmulos, com alguns identificados apenas por uma cruz fincada ao solo. Provavelmente os jazigos, que na maioria dos casos se restringia a esquifes, deveriam pertencer a pessoas com maior prestígio social, ligadas à cafeicultura ou a monarquia brasileira, e os túmulos identificados pelas cruzes deveriam pertencer aos escravos, indigentes e outras pessoas de baixo nível social. Nessa época o cemitério não apresentava qualquer pavimentação. 


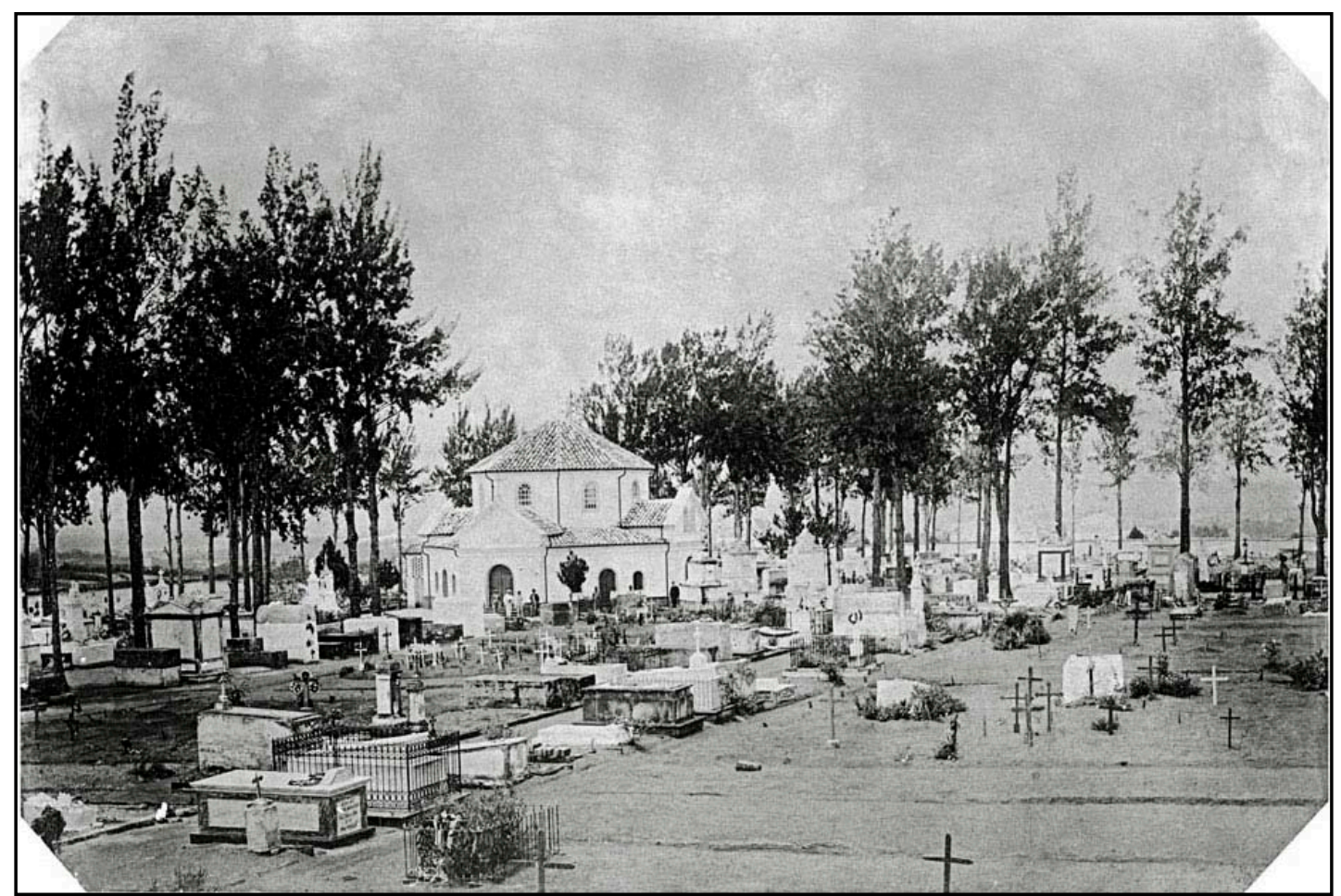

Figura 8. Cemitério da Consolação em 1887.

Fotógrafo: Militão Augusto de Azevedo.

Fonte: Acervo Fotográfico da Casa da Imagem.

Em 1894, a comunidade francesa prestou homenagem ao presidente francês assassinado Sadi Carnot, com a inauguração de um jazigo simbólico (Figura 9). Nãohá referência bibliográfica de qual seria o jazigo na fotografia, entretanto pela disposição das pessoas ao redor de um túmulo especifico e notando-se que as mesmas estão atentas ao fotógrafo, deve tratar-se do jazigo que possui um busto esculpido na parte superior. Atualmente não há registro a respeito da localização ou existência desse túmulo, pela fotografia e pela disposição dos muros e árvores, sua localização pode ser inferida próxima, ao que é hoje, o portão secundário de acesso, localizado na Rua Mato Grosso. 


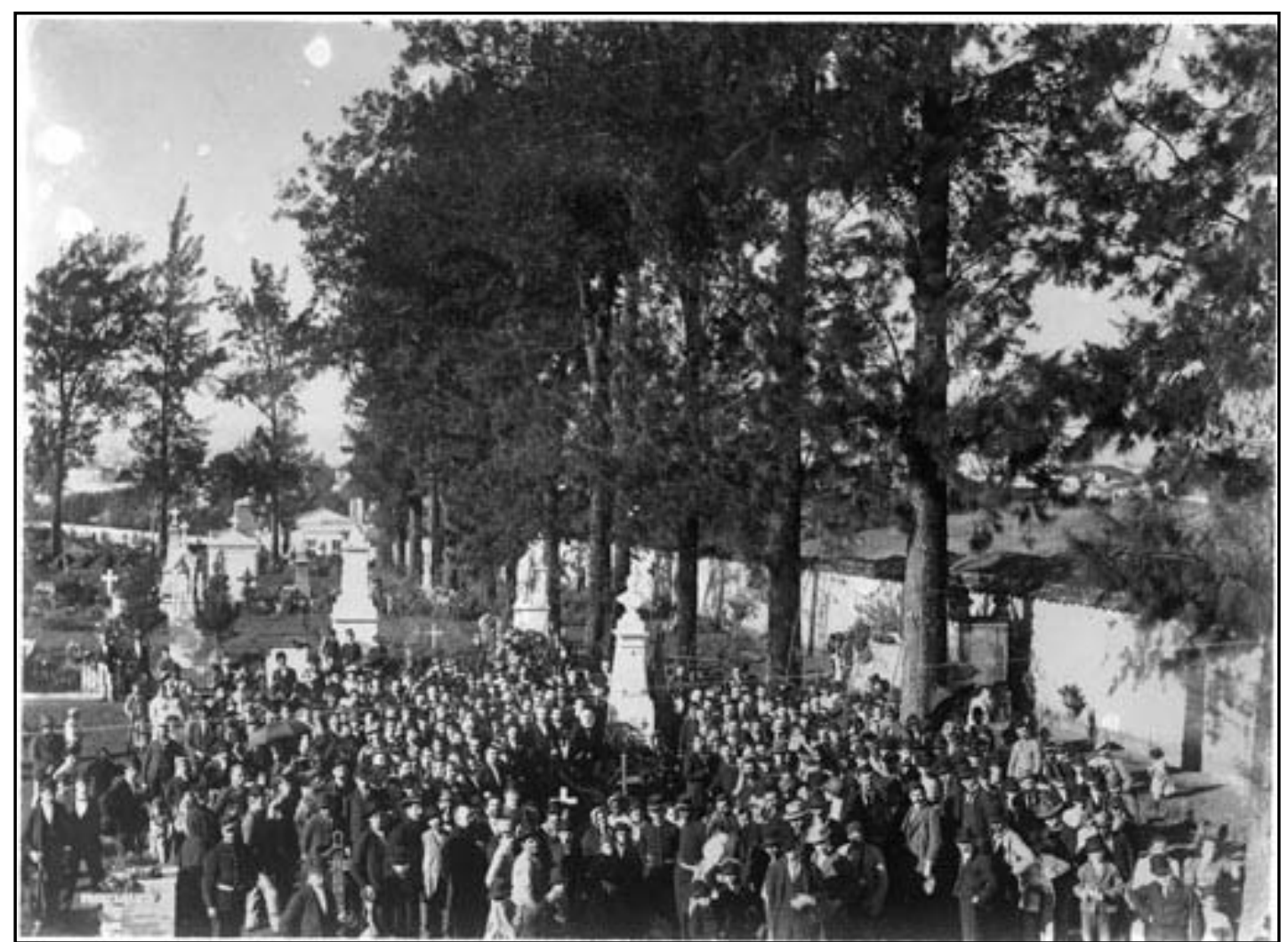

Figura 9. Fotografia do Cemitério da Consolação retratando a inauguração do mausoléu simbólico que a comunidade francesa construiu em memória de Sadi Carnot em 14 de julho de 1894.

Fonte: Acervo Fotográfico da Casa da Imagem.

Com a revitalização do cemitério e com o desenvolvimento econômico de São Paulo, o perfil dos sepultados começou a mudar. Nessa época começou a se confeccionar túmulos mais elaborados, com presença de estátuas, não se restringindo somente às esquifes (Figura 8). Pela análise da constituição pétrea dos túmulos do final do século XIX existentes atualmente no cemitério, é possível afirmar que o mármore era a principal rocha utilizada, empregada em túmulos construídos pela sobreposição de estruturas retangulares, atingindo cerca de 2 metros de altura, abrigando na sua parte superior alguma estatuária. Esse tipo de túmulo era o mais encontrado até meados da década de 1920 (Figuras 10 e 11). 


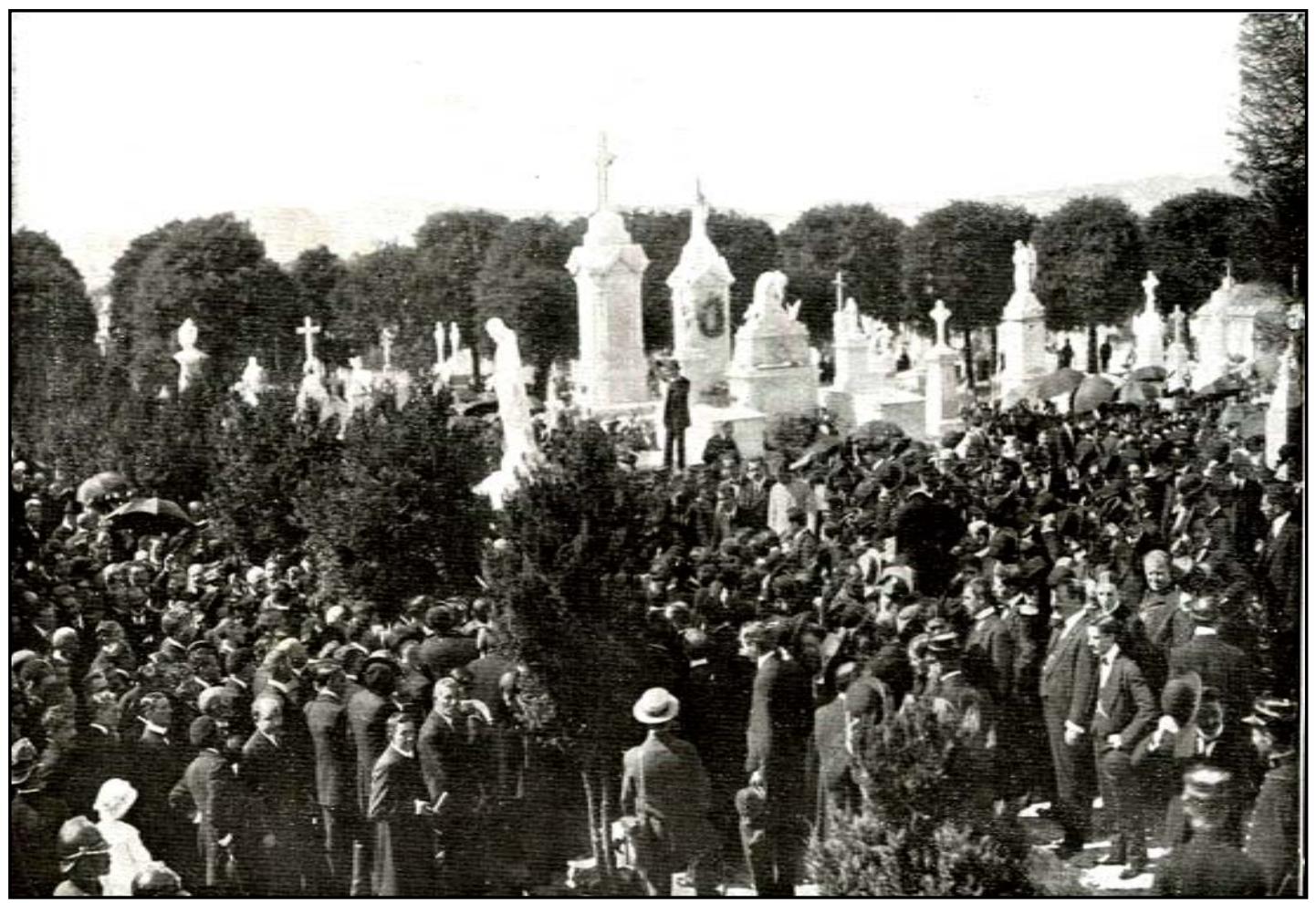

Figura 10. Fotografia do sepultamento do ex-presidente Bernardino de Campos, em 1915. Fonte: Revista "A Cigarra", edição de 5 de fevereiro de 1915.

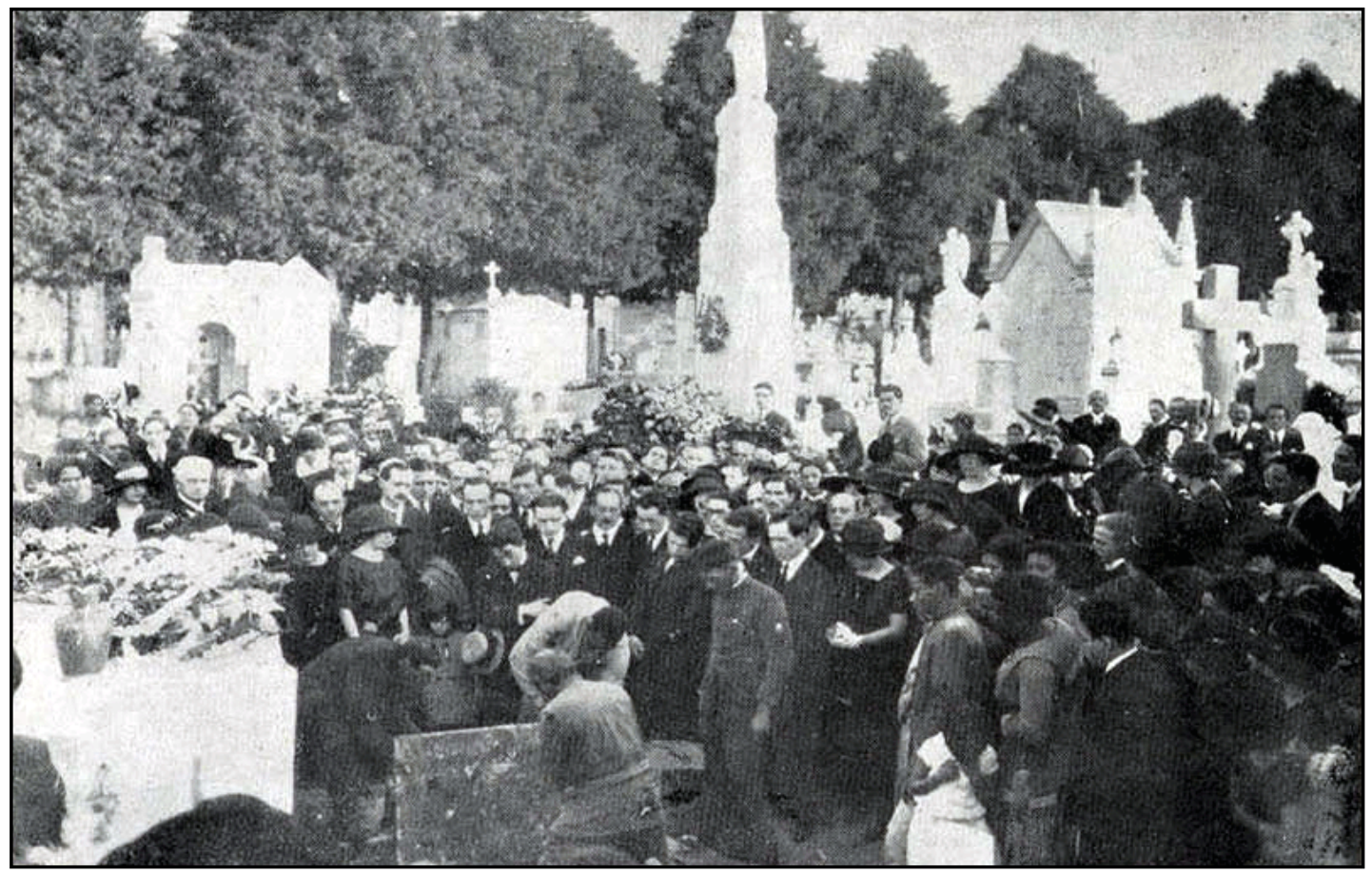

Figura 11. Fotografia do sepultamento do maestro Luiz Chiaffarelli no Cemitério da Consolação, em 1923.

Fonte: Revista "A Cigarra", edição de 15 de junho de 1923. 
Um importante aspecto relacionado à conservação de monumentos é a presença de vegetação e altos índices de poluição. O Cemitério da Consolação não apresentava plantas superiores com grande representatividade até meados da década de 1960, como é constatado pela fotografia aérea (Figura 12). O tráfego pela rua da Consolação até a época citada não era intenso, não só porque a frota de automóveis de São Paulo era reduzida, mas também porque a rua da Consolação era uma via de mão única, sendo duplicada apenas em 1968 (Figura 13). Desta forma, até a década de 1960 a poluiçãoe a vegetação não eram agentes importantes, sendo que a exposição direta aos raios solares (intemperimso físico) deveria ser o principal agente nessa época. Foi da década de 1960 para os dias atuais que os principais problemas de deterioração que serão abordados se desenvolveram.

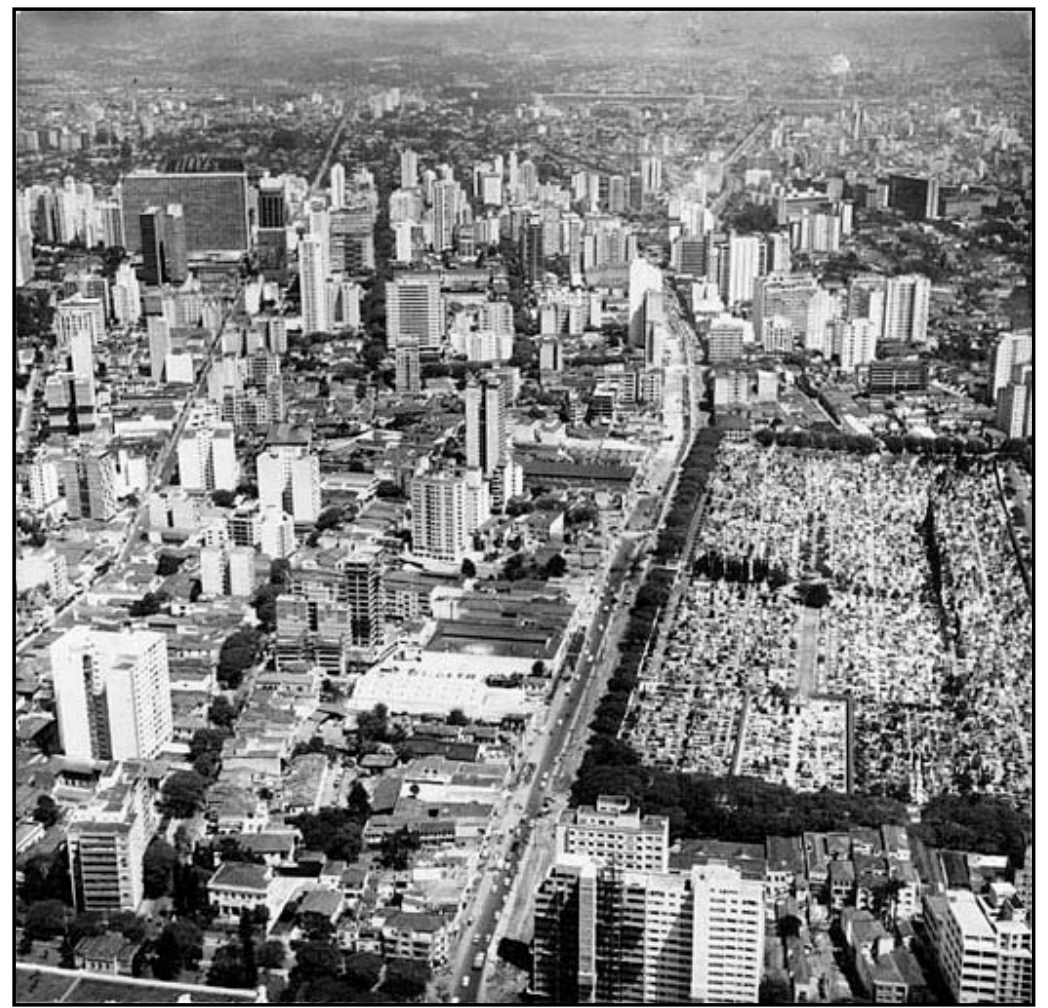

Figura 12. Vista aérea da rua da Consolação em 1968, mostrando com maior detalhe o Cemitério da Consolação. Fotógrafo: Ivo Justino.

Fonte: Acervo Fotográfico da Casa da Imagem. 


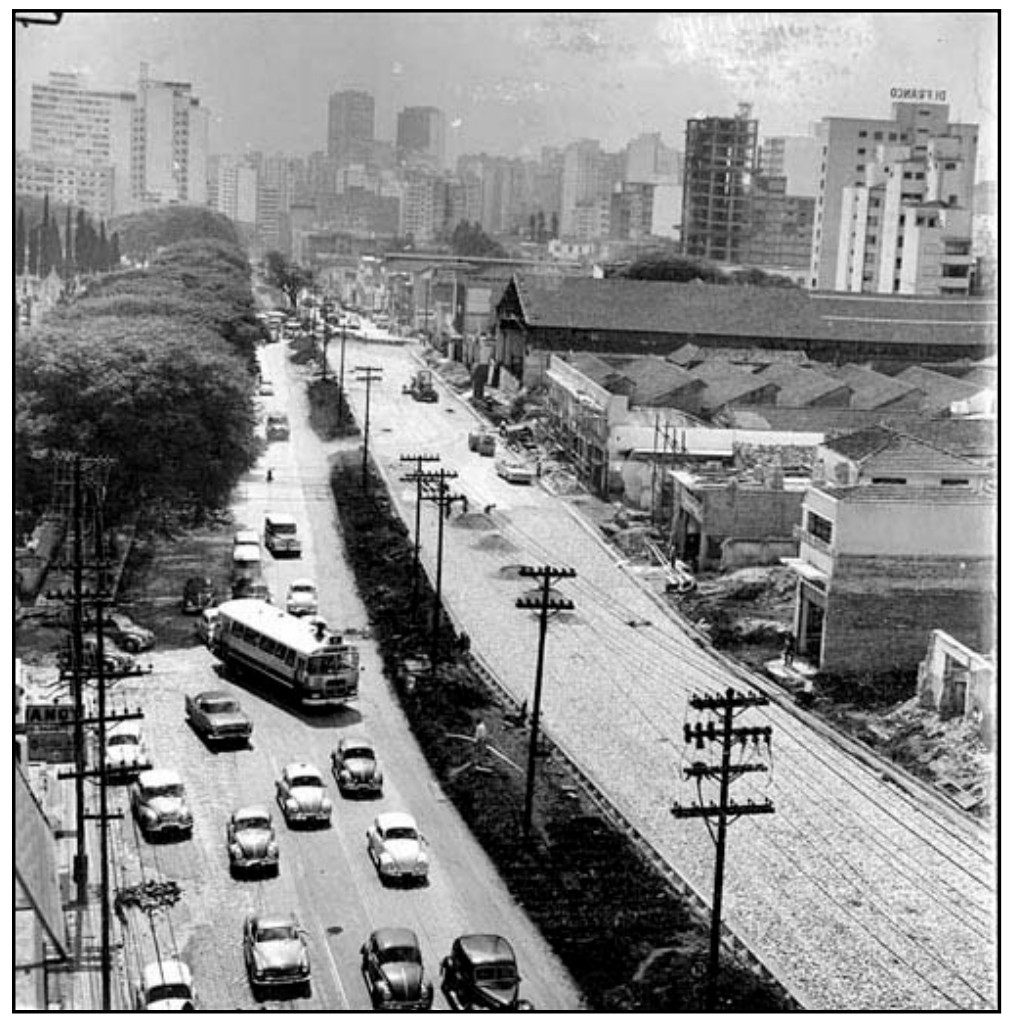

Figura 13. Rua da Consolação em 1968, em frente ao cemitério da Consolação (lado esquerdo). Fotógrafo: Ivo Justino.

Fonte: Acervo Fotográfico da Casa da Imagem.

\section{MÉTODOS NÃO DESTRUTIVOS UTILIZADOS NO ESTUDO DOS MONUMENTOS PÉTREOS}

As investigações não destrutivas abrangeram a determinação dos litotipos existentes na necrópole, os quais foram avaliados em relação ao desenvolvimento dos padrões de deterioração, e no caso de alguns jazigos constituídos pelo Granito Itaquera ou mármore, foram realizados estudos relativos a mudança da cor da rocha, pelo uso do espectrofotômetro, e variação da sua homogeneidade, pela variação das velocidades de propagação das ondas ultrassônicas. Os resultados obtidos são apresentados a seguir.

\subsection{DETERMINAÇÃO DOS MATERIAIS GEOLÓGICOS EXISTENTES NO CEMITÉRIO DA CONSOLAÇÃO}

A utilização de diferentes tipos de rochas, para diversas finalidades é um hábito comum desde as primeiras civilizações. Em construções mortuárias, a rocha foi o primeiro material utilizado, presente, por exemplo, nas tumbas de Newgrange, Irlanda (3.100 a.C.), na pirâmide de Quéops, Egito (2.600 a.C.), nos menires de Carnac, França (2.000 a.C.), nos túmulos comunitários escavados em paredões rochosos em Petra, Jordânia (40 à 5 a.C.), 
presente até os dias atuais nos cemitérios do Brasil e do exterior (Kuzmickas e Del Lama, 2011).

Do ponto de vista geológico, as rochas podem ser enquadradas em três grandes grupos genéticos: ígneo, sedimentar e metamórfico. Em relação à questão comercial, as rochas ornamentais (matérias geológicos naturais extraídos na forma de blocos ou placas, cortados em variadas formas e beneficiadas por meio de polimento, lustro, etc), são subdivididas basicamente em granitos e mármores, existindo ainda outras rochas comercialmente importantes como o quartzito, serpentinito, travertino, calcário (também chamado de limestone) e ardósia. Essas rochas, em função das suas similaridades mineralógicas, estruturais e texturais, podem ser agrupadas, segundo Mello et al. (2011), genericamente nos seguintes grupos: rochas silicáticas (granito e similares); rochas carbonáticas (mármore, travertino e calcário); rochas silicosas (quartzito, chert e similares); rochas síltico-argilosas foliadas (ardósia); e rochas ultramáficas (serpentinito, pedrão-sabão e pedra-talco).

As rochas silicáticas abrangem as rochas ígneas plutônicas e vulcânicas como monzonitos, granodioritos, charnockitos, sienitos, dioritos, gabros, basaltos, além das rochas metamórficas de alto grau como os gnaisses e a rochas formadas pela fusão parcial ou total de materiais crustais pré-existentes, classificadas como migmatitos. A caracterização comercial dessas rochas geralmente considera as características cromáticas (determinada pela mineralogia), as características estruturais, abrangendo as rochas homogêneas (estrutura maciça) e as rochas movimentadas (estrutura bandada, orientadas, etc) e as características texturais (textura afanítica, fanerítica, porfirítica, granoblástica, nematoblástica, etc).

As rochas carbonáticas abrangem os litotipos constituídos predominantemente por calcita e/ou dolomita, compreendendo: os calcários biodetríticos, formados pela deposição de conchas e esqueletos de outros animais em ambiente marinho; travertinos e margas, formados pela precipitação química ou bioquímica de carbonatos em ambientes de águadoce; e os mármores, formados pelo metamorfismo de rochas carbonáticas pré-existentes. Nessas rochas é comum encontrar impurezas como matéria orgânica, mica, quartzo, anfibólio e sulfeto.

As rochas silicosas, que nesse caso abrange apenas o quartzito, são rochas metamórficas com textura sacaróide, derivadas da recristalização de rochas sedimentares quartzosas. Os minerais acessórios mais comuns são micas, zircão, magnetita/ilmenita, hidróxido de ferro e de manganês, que determinam o padrão cromático.

As rochas síltico-argilosas foliadas são metassedimentos formados pelo metamorfismo de baixo grau de sequências argilosas e síltico-argilosas. Por serem constituídas essencialmente por minerais estáveis como quartzo, mica e clorita, as ardósias são 
resistentes à meteorização, sendo bastante duráveis. Algumas impurezas como carbonatos podem diminuir a sua durabilidade quando atacadas por soluções ácidas; e a presença de pirita, quando oxidada, proporciona a coloração avermelhada a ardósias com cor cinza ou preta.

O grupo das rochas ultramáficas é representado por rochas metamórficas constituídas por associações entre serpentina, tremolita/actinolita, clorita, talco e carbonato, com ausência de quartzo e feldspato. Entre os representantes desse grupo, a pedra-sabão e a pedra-talco são muito utilizadas na confecção de objetos decorativos e na cantaria.

No Cemitério da Consolação a rocha é o material mais utilizado nos túmulos, seja na parte estrutural, como revestimento ou na ornamentação (estátuas, vasos, ornatos esculpidos no revestimento). É comum encontrar em um mesmo túmulo vários tipos de rochas sendo utilizadas, aparentemente por critério estético. Os litotipos não apresentam uma distribuição regular no cemitério, entretanto nota-se que as primeiras quadras construídas são as que possuem os jazigos mais antigos, constituídos por mármore. Isso não é evidente devido à elitização do cemitério que ocorreu no final do século XIX, quando muitos túmulos foram desapropriados e demolidos. Não há referências a respeito da proveniência das rochas utilizadas nos jazigos ou em outras estruturas presentes. Gomes (2007) comenta a respeito da prática de Rui Ribeiro Franco, professor do curso de geologia da Universidade de São Paulo, que na década de 1970 levava seus alunos ao Cemitério da Consolação, onde os numerosos túmulos com revestimento de placas de rochas ofereciam excelentes condições para exame.

Foram identificadas litologias dos três grandes grupos de rochas (sedimentar, ígnea e metamórfica), com grande variação estrutural, textural e mineralógica. A proveniência dos litotipos foi inferida a partir da determinação dos seus nomes comerciais.

Em relação às rochas carbonáticas, os mármores que compõe os túmulos antigos certamente são importados. Vários desses jazigos foram construídos pela Marmoraria Tavolaro, que era uma importadora e se localizava na Rua da Consolação (Figura 14), anunciava na revista "A Cigarra" (Figura 15). Dois calcários identificados, o Lioz e o Rosso Verona, são rochas importadas respectivamente de Portugal e Itália, sendo utilizadas em vários monumentos nos seus países de origem. O mármore Nero Portorofoi importado da Itália. 


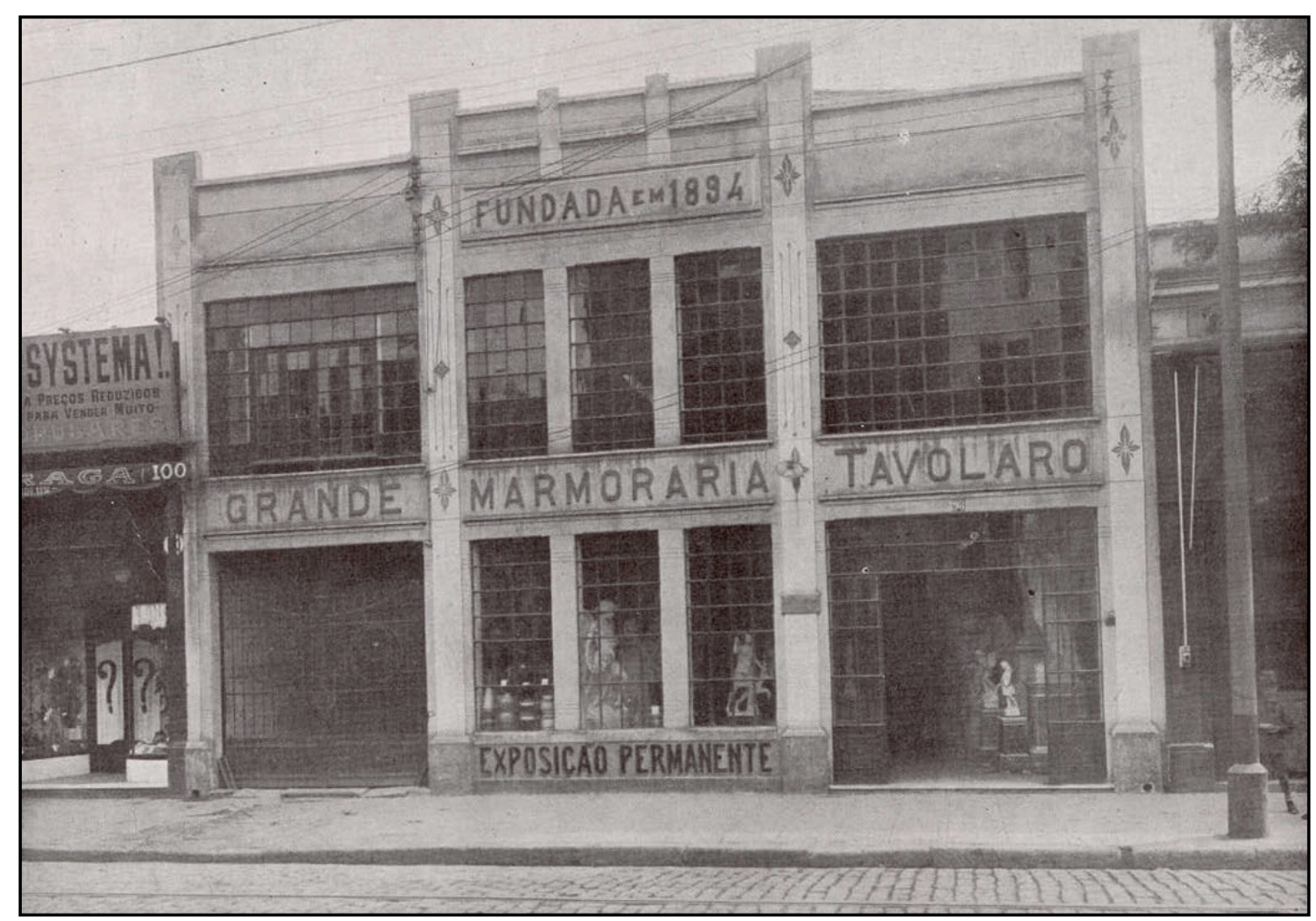

Figura 14. Fotografia da Marmoraria Tavolaro, que se localizava na Rua da Consolação, 98. Possuía exposição permanente de túmulos em mármore e granito, além de grande variedade de estatuária, vasos e cruzes.

Revista "A Cigarra", edição de 15 de junho de 1923.

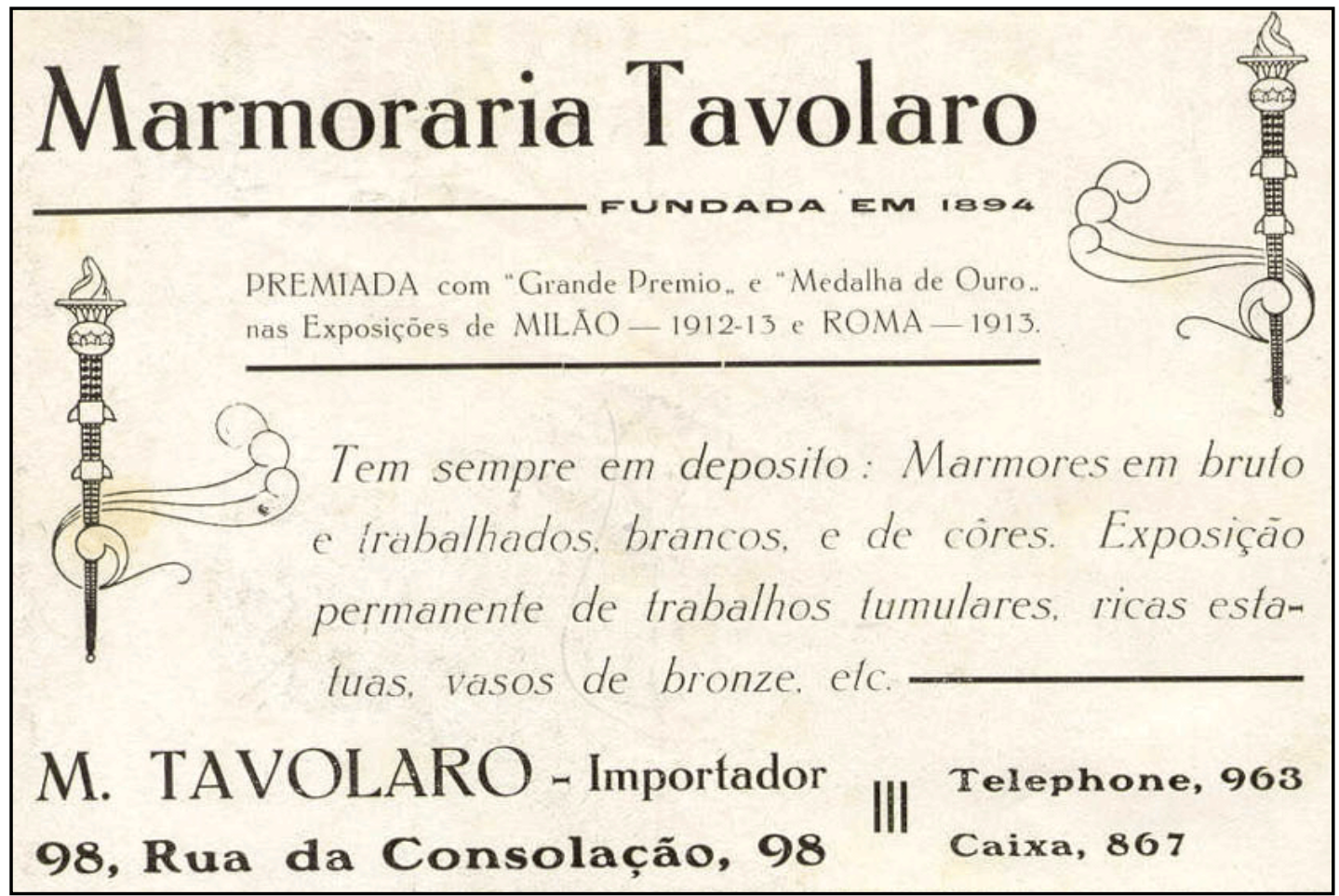

Figura 15. Anúncio comercial da Marmoraria Tavolaro na revista "A Cigarra".

Fonte: Revista "A Cigarra", edição de 15 de junho de 1923. 
Em relação às rochas silicosas, rochas sílticos-argilosas foliadas e rochas silicáticas, todas, com exceção da rocha azul norueguês, proveniente da Noruega, são brasileiras, com a grande maioria proveniente do estado de São Paulo. Destas destaca-se o Granito Itaquera, rocha muito utilizada nos monumentos da cidade de São Paulo, empregada em alguns jazigos do cemitério, incluindo túmulos datados do final do século XIX (Família Pereira Pinto), constituindo uma das referências mais antigas da utilização dessa rocha na cidade de São Paulo.

As principais rochas encontradas no Cemitério da Consolação, seus nomes comerciais e petrográficos, e o túmulo exemplo, estão representados nas Tabelas 1, 2 e 3.

Tabela 1. Rochas carbonáticas identificadas no Cemitério da Consolação.

\begin{tabular}{|c|c|c|}
\hline \multicolumn{3}{|c|}{ ROCHAS CARBONÁTICAS } \\
\hline NOME COMERCIAL & NOME PETROGRÁFICO & EXEMPLO I LOCALIZAÇÃO \\
\hline Travertino Romano & Travertino & $\begin{array}{c}\text { Túmulo da Família Joaquim } \\
\text { dos Santos - Escultura "O } \\
\text { Adeus" (1953) de Galileu } \\
\text { Emendabili }\end{array}$ \\
\hline Lioz & Calcário Fossilífero & $\begin{array}{l}\text { Túmulo da Família Francisco } \\
\text { da Fonseca Moraes Galvão }\end{array}$ \\
\hline- & Calcário Fossilífero & $\begin{array}{l}\text { Túmulo de Eleuterio da Silva } \\
\text { Prado }\end{array}$ \\
\hline Rosso Verona & Calcário & $\begin{array}{c}\text { Túmulo da Família Matarazzo } \\
\text { - Grupo Escultório (1925) de } \\
\text { Luigi Brizzolara }\end{array}$ \\
\hline Mármore & Mármore & $\begin{array}{l}\text { Túmulo de Armando de Sales } \\
\text { Oliveira - Escultura "Prece" } \\
\text { (1970) de Bruno Giorgi }\end{array}$ \\
\hline Mármore Branco Nacional & Mármore & Túmulo da Família Pilla \\
\hline Mármore Rosa Siena & Mármore & $\begin{array}{l}\text { Túmulo de Maria de Fátima } \\
\text { Rodrigues Guerra }\end{array}$ \\
\hline Mármore Nero Portoro & Mármore & Túmulo da Família Siciliano \\
\hline
\end{tabular}


Tabela 2. Rochas silicosas e rochas síltico-argilosas foliadas identificadas no cemitério da Consolação.

\begin{tabular}{c|c|c|}
\hline \multicolumn{2}{|c|}{ ROCHAS SILICOSAS I ROCHAS SÍLTICO - ARGILOSAS FOLIADAS } \\
\hline NOME COMERCIAL & NOME PETROGRÁFICO & EXEMPLO I LOCALIZAÇÃo \\
\hline \hline Ardósia Cinza & Ardósia & Túmulo da Família Appelt \\
\hline Quartzito Branco & Quartzito & $\begin{array}{c}\text { Túmulo de Luiz Pacheco de } \\
\text { Toledo }\end{array}$ \\
\hline
\end{tabular}

Tabela 3. Rochas silicáticas identificadas no cemitério da Consolação.

\begin{tabular}{|c|c|c|}
\hline \multicolumn{3}{|c|}{ ROCHAS SILICÁTICAS } \\
\hline NOME COMERCIAL & NOME PETROGRÁFICO & EXEMPLO / LOCALIZAÇÃO \\
\hline Granito Itaquera & Biotita Granito & $\begin{array}{l}\text { Túmulo da Família Álvares } \\
\text { Penteado - Escultura } \\
\text { "Sepultamento" (1923) de } \\
\text { Victor Brecheret }\end{array}$ \\
\hline Cinza Mauá & Biotita Granito Porfirítico & $\begin{array}{l}\text { Túmulo da Família Botti - } \\
\text { Escultura "Grande Anjo" } \\
\text { (1938) de Victor Brecheret }\end{array}$ \\
\hline Àz de Paus & Biotita Granito & Túmulo da Família Erango \\
\hline Rosa Salto & Biotita Granito & $\begin{array}{l}\text { Túmulo da Família Trevisioli - } \\
\text { Escultura "A Lenda Grega" } \\
\text { (1920) de Nicolla Rollo }\end{array}$ \\
\hline Vermelho Brasília & Bitotita Granito & $\begin{array}{l}\text { Túmulo da Família Conde de } \\
\text { Alvares Penteado - Rocha } \\
\text { ornamental presente nas } \\
\text { paredes exteriores da capela }\end{array}$ \\
\hline Amarelo Cabaças & Sienogranito & $\begin{array}{c}\text { Túmulo da Família Chedid } \\
\text { Jafet - Escultura de Antelo Del } \\
\text { Debbio }\end{array}$ \\
\hline Vermelho Bragança & Biotita Granito Porfirítico & $\begin{array}{l}\text { Túmulo da Família Curi } \\
\text { Kachan }\end{array}$ \\
\hline Marrom São Paulo & Biotita Granito & $\begin{array}{c}\text { Túmulo da Família Affonso } \\
\text { Bruno }\end{array}$ \\
\hline Azul Ribeira & Riebeckita Álcali - Granito & Túmulo da Família Antonacio \\
\hline
\end{tabular}




\begin{tabular}{|c|c|c|}
\hline Verde Ubatuba & Charnockito & Túmulo da Família Feres \\
\hline Preto Piracaia & Monzonito & $\begin{array}{l}\text { Túmulo da Família Comm. } \\
\text { Sabbado D’Angelo }\end{array}$ \\
\hline Preto Bragança & Monzonito & $\begin{array}{c}\text { Túmulo do Escritor Monteiro } \\
\text { Lobato }\end{array}$ \\
\hline Azul Norueguês & Larviquito & $\begin{array}{c}\text { Túmulo de Luiz de Toledo } \\
\text { Piza e Almeida - Rocha } \\
\text { ornamental que constitui o } \\
\text { sarcófago. }\end{array}$ \\
\hline Porto Rosa & Gnaisse Migmatítico & $\begin{array}{l}\text { Túmulo da Família Jambeiro } \\
\text { Costa }\end{array}$ \\
\hline Granito Verde Candeias & Gnaisse Migmatítico & Túmulo da Família Tisi \\
\hline Granito Preto Indiano & Gnaisse Migmatítico & Túmulo da Família Catalano \\
\hline Granito Branco Dallas & Gnaisse & $\begin{array}{l}\text { Túmulo da Família } \\
\text { Zandomeneghi }\end{array}$ \\
\hline
\end{tabular}

As rochas não são os únicos materiais geológicos presentes no Cemitério da Consolação, além dos seixos de sílex que foram utilizados como pedra de pavimentação (Figura 16), alguns túmulos possuem minerais que lhes confere características singulares, evidenciando o potencial geoturístico da necrópole.

O alabastro (gipsita) substitui o vidro na janela ornamental existente no túmulo de Ramos de Azevedo (Figura 17). A mica, presente em vários litotipos, foi adicionada a argamassa para proporcionar aspecto brilhoso ao jazigo da Família Americano (Figura 18). Esse tipo de revestimento possui vários nomes (Arquitetura da Mica, Cirocreto ou Cirex), tendo sido muito utilizado nas fachadas de estilo art déco nas décadas de 1930 e 1940 (Revista $A U, 2013$ ). Um exemplo único encontrado na necrópole é a presença de um geodo de quartzo (Figura19), que ornamenta o jazigo da família Dr. Rachid Milan, possuindo na sua parte posterior agregados de cristais de calcita idiomórficos (Figura 20). 


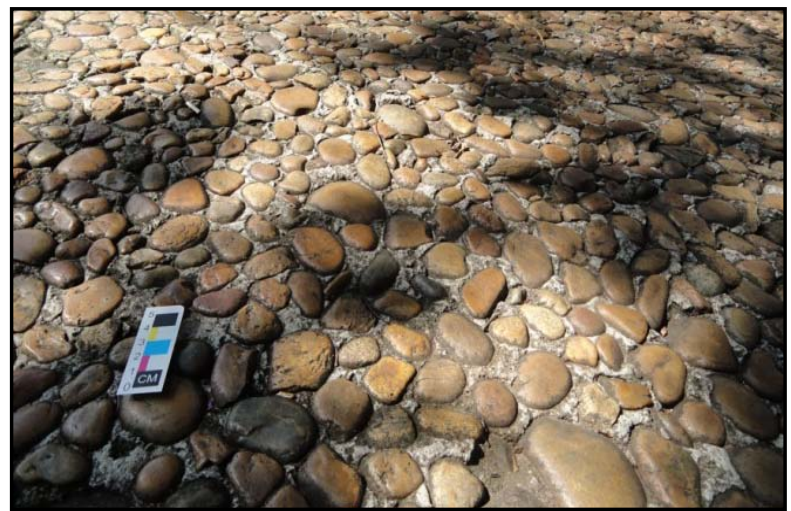

Figura 16. Pavimentação com seixos de sílex.

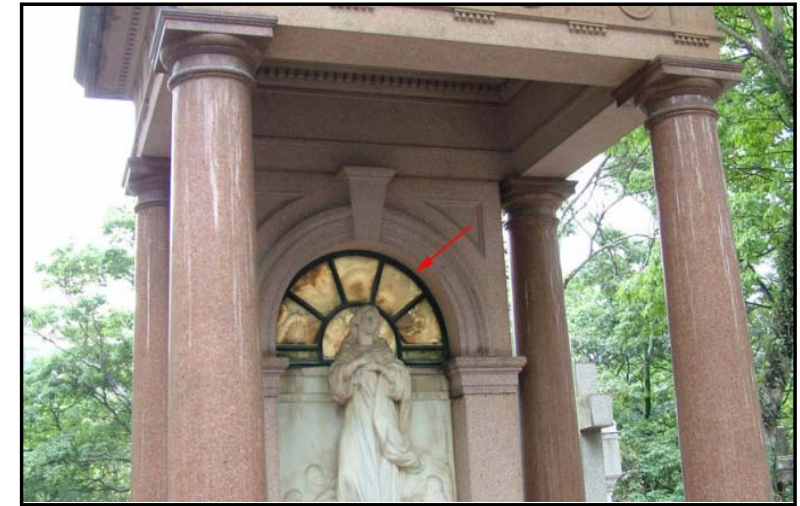

Figura 17. Revestimento da janela constituído por alabastro.

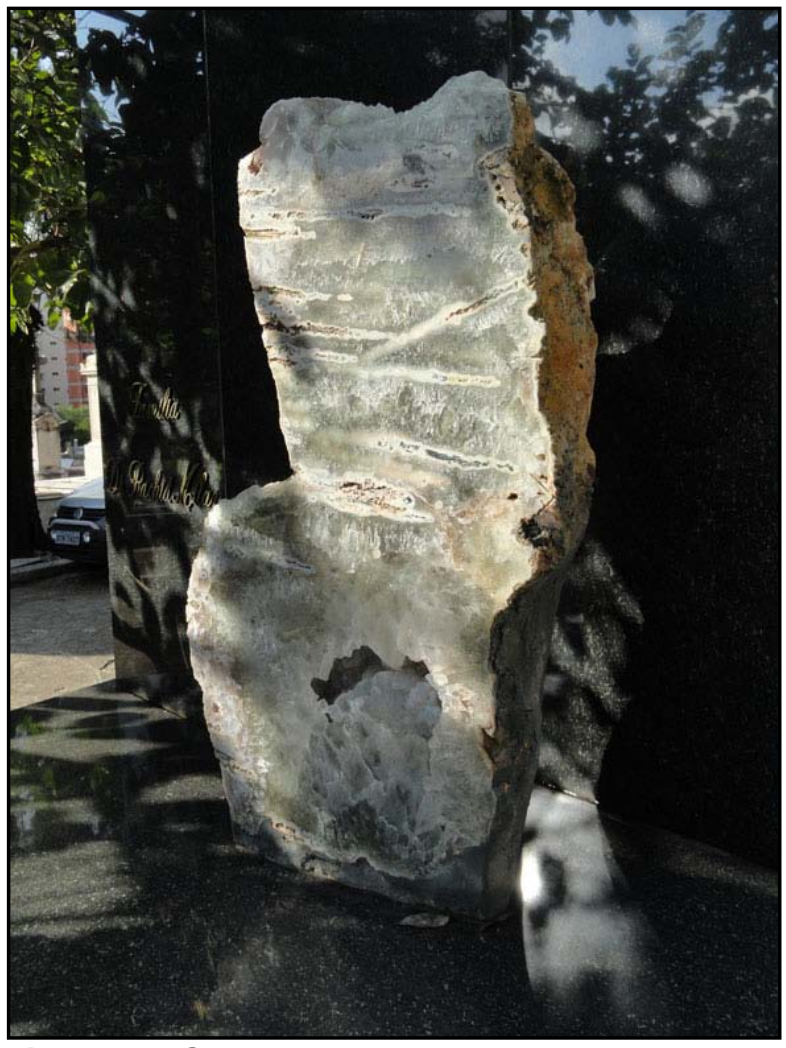

Figura 19. Geodo de quartzo.

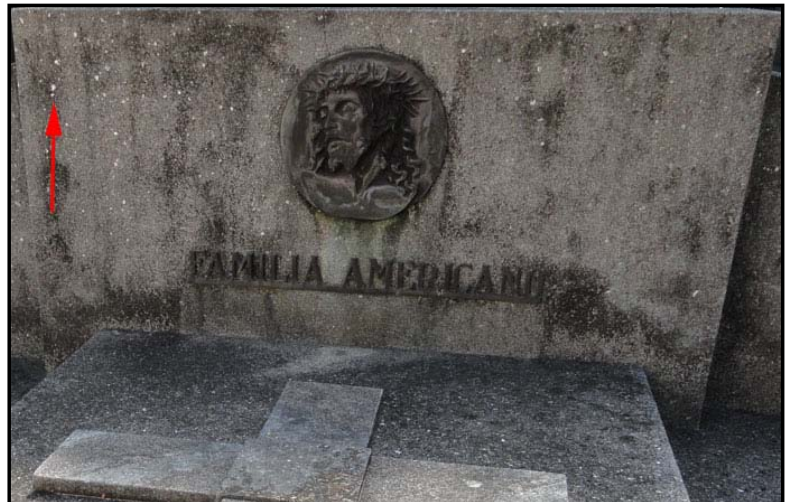

Figura 18. Mica sendo utilizada na constituição do concreto (seta vermelha).

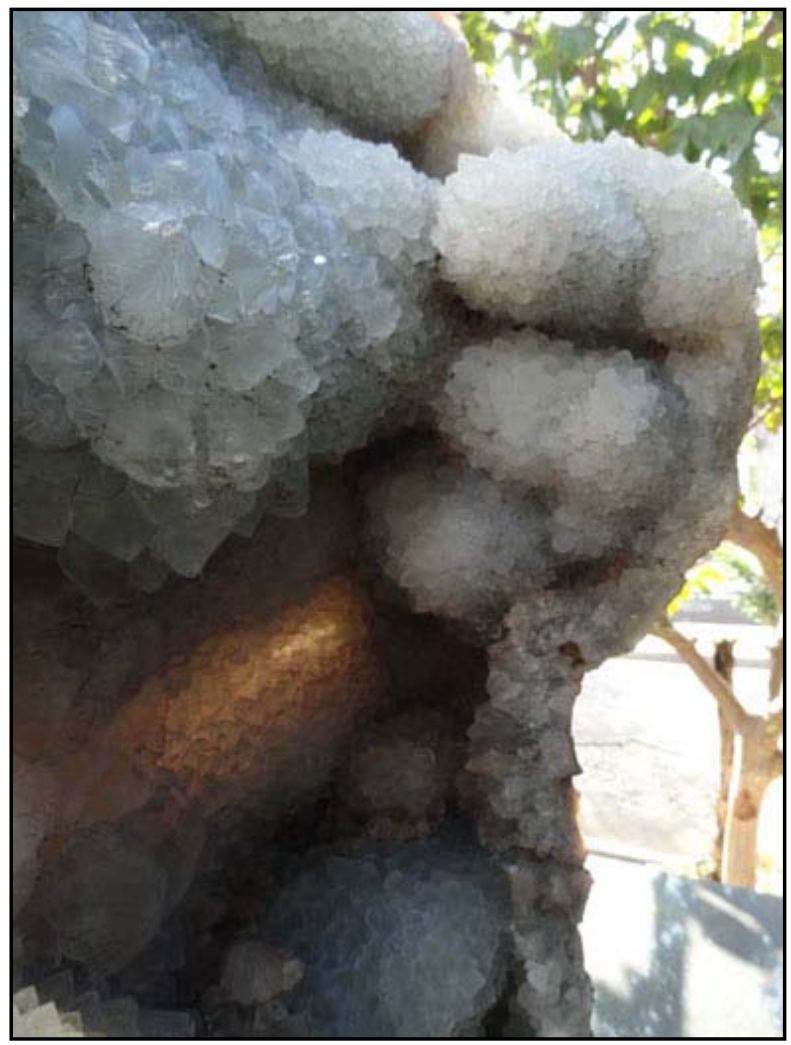

Figura 20. Parte posterior do geodo; presença de cristais idiomórficos de calcita. 


\subsection{MAPEAMENTO DOS PADRÕES DE DETERIORAÇÃO DA ROCHA}

Todos os geomateriais da superfície da Terra expostos nas paisagens naturais ou em construções são suscetíveis ao intemperismo, um problema identificado nos monumentos históricos desde a antiguidade (Siegesmund et al., 2002), que compreende três tipos: físico, químico e biológico.

O intemperismo físico é causado especificamente por processos que geram forças físicas na rocha ou em descontinuidades pré-existentes, como os ciclos de congelamentodescongelamento da água, solubilização-cristalização de sais ou expansão-retração termal, que ocasionam microfraturas intra e intercristalinas, fissuras, fragmentação ou escamação da rocha.

O intemperismo químico é o resultado de reações químicas que ocorrem entre a água, dióxido de carbono ou oxigênio do ar, com os minerais constituintes das rochas, preferencialmente em descontinuidades ou na sua superfície. As reações de alteração podem ser dos seguintes tipos: dissolução, redução, oxidação-hidratação, oxidação e hidrólise (Frascá, 2003).

O intemperismo biológico é caracterizado pela colonização do material rochoso por organismos vivos, como musgos, algas, liquens e plantas superiores, que geram ácidos que atacam os minerais constituintes das rochas. Podem causar também o seu fraturamento devido ao crescimento de raízes.

Os tipos de intemperismo apresentados podem ocorrer de forma integrada, desenvolvendo padrões de deterioração que ajudam a identificar os mecanismos envolvidos na alteração das rochas. Para a descrição dos padrões de alteração foram criados diversos glossários por organizações governamentais (Grimmer, 1984), grupos de pesquisa (Fitzner e Heinrichs, 2004; Henriques et al., 2005), entre outros.

Um dos catálogos mais famosos é o de Fitzner e Heinrichs (2004), que apresenta cento e dez formas de alteração, divididos em quatro grupos principais, tendo sido utilizado em vários estudos de caso (Fitzner et al., 2002; Fitzner et al., 2003; Heinrichs e Fitzner, 2007).

O catálogo proposto por Henriques et al. (2005) descreve de maneira objetiva vinte e oito formas de alteração, o que torna o mapeamento das formas de deterioração muito mais fácil se comparado com a utilização do proposto por Fitzner e Heinrichs (2004). No Brasil, esse catálogo foi utilizado em vários trabalhos (Reys et al., 2007; Del Lama et al., 2008; Del Lama et al., 2009).

Um dos grandes problemas relacionados a discussão das formas de alteração da rocha é encontrar uma linguagem comum (Doehne e Price, 2010), pois muitos dos termos apresentados nos catálogos podem parecer redundantes. Por esse motivo foi elaborado o 
Glossário Ilustrado de Padrões de Deterioração de Rocha pelo ICOMOS - ISCS (Conselho Internacional de Monumentos e Sítios - Comitê Científico Internacional para Pedra), que ajuda a definir e esclarecer o uso de vários termos anteriormente apresentados, produzido a partir da compilação de vários trabalhos importantes que abrangem essa temática. $\mathrm{O}$ glossário divide as formas de degradação em cinco grupos: fissura e deformação, destacamento, feições induzidas pela perda de material, alteração cromática e depósito, e colonização biológica. Esses grupos são divididos por sua vez em subgrupos, sendo que os apresentados nesse trabalho são descritos a seguir.

\section{A - Fissura e Deformação (Crack \& Deformation)}

- Fissura (Crack): fenda contínua, claramente visível a olho nu, resultante da separação de uma parte em relação à outra (Figuras 21 e 22).

- Deformação (Deformation): mudança na forma, sem perda da integridade, levando a flexão ou torção de um bloco de rocha (Figuras 23 e 24).

\section{B - Destacamento (Detachment)}

- Rompimento (Bursting): perda localizada da rocha devido à despressurização interna, geralmente manifestando-se de forma irregular (Figuras 25 e 26).

- Desintegração (Disintegration): desintegração de grãos simples ou agregados de grãos (Figuras 27 e 28).

- Descamação (Scaling): separação em forma de escamas das partes exteriores de uma rocha, sem seguir qualquer estrutura existente, geralmente possuindo uma escala milimétrica a centimétrica (Figuras 29 e 30).

\section{C - Feições Induzidas pela Perda de Material (Features Induced by Material Loss)}

- Alveolização (Alveolization): formação, na superfície da rocha, de cavidades que podem ser conectadas e ter diferentes formas e tamanhos (Figuras 31 e 32).

- Erosão Diferencial (Differential Erosion): erosão da superfície de uma rocha de maneira heterogênea (Figuras 33 e 34).

- Perda de Parte (Missing Part): perda de partes da rocha. Protuberâncias como narizes e dedos de esculturas são típicas porções faltantes (Figuras 35 e 36).

- Perfuração (Perforation): uma única ou série de perfurações superficiais, produzidas por um instrumento afiado ou por algum animal (Figuras 37 e 38). 


\section{D - Alteração Cromática e Depósito (Discoloration \& Deposit)}

- Crosta (Crust): acumulação de matérias na superfície da pedra, podendo incluir a combinação de depósitos exógenos com materiais derivados da rocha. Pode apresentar espessura homogênea e, portanto, replicar as características do monumento, ou ter uma espessura irregular e perturbar a leitura dos seus pormenores. A crosta pode apresentar-se em diversas cores, quando possui cor escura e ocorre em rochas carbonáticas é chamada de crosta negra. Esta se desenvolve em áreas protegidas da chuva direta ou do escoamento de água em ambiente urbano, sendo definida pelo conjunto de três camadas distintas: uma superficial e sem coesão, tratando-se do depósito exógeno; uma intermediária, endurecida, composta por gipsita; e a mais profunda, bastante pulverulenta, tratando-se da rocha desagregada (Figuras 39 e 40).

- Depósito (Deposit): acumulação de material exógeno de espessura variada. Alguns exemplos de depósitos são borrifados de tinta ou argamassa, aerossóis marinhos, partículas atmosféricas como poeira e fuligem e remanescentes de materiais utilizados em trabalhos de conservação, como emplasto de celulose (Figuras 41 e 42).

- Alteração Cromática (Discolouration): mudança na cor original da rocha em pelo menos um de seus três parâmetros, sendo eles matiz, tonalidade e saturação (Figuras 43 e 44).

- Eflorescência (Efflorescence): material esbranquiçado, pulverulento que pode ocorrer como cristais alongados, geralmente sem coesão e comumente composto por sais solúveis (Figuras 45 e 46).

- Incrustação (Encrustation): camada mineral compacta e rígida, que adere a parte exterior da rocha. Incrustação com formato específico, como por exemplo, formato nodular, botrioidal (formato de cachos de uvas), framboidal (formato de framboesa), ou apresentando-se na forma de estalactites ou estalagmites, recebe o nome de concreção (Figuras 47 e 48).

- Filme (Film): camada fina de revestimento, geralmente de natureza orgânica e homogênea, seguindo a superfície da rocha. Camadas pintadas, certos tipos de repelentes de água, antigrafites e consolidantes são considerados filmes (Figuras 49 e 50).

- Grafite (Graffiti): gravação ou aplicação de tintas e similares na superfície das rochas. Grafite é geralmente resultado de atos de vandalismo, entretanto alguns 
possuem valor histórico, estético e cultural e devem ser conservados (Figuras 51 e 52).

- Pátina (Patine): modificações cromáticas da rocha, devido a seu envelhecimento natural ou artificial, não possuindo, na maioria dos casos, uma superfície de deterioração. Pátinas com coloração preta amarronzada podem ser encontradas em arenitos contaminados com óxido de ferro e/ou argilominerais. Pátinas com coloração amarela amarronzada podem indicar a presença de oxalato de cálcio, sendo encontradas frequentemente no substrato de mármores e rochas carbonáticas (Figuras 53 e 54).

- Sujidade (Soiling): camada muito fina de partículas exógenas, proporcionando uma aparência suja a superfície da rocha (Figuras 55 e 56).

\section{E - Colonização Biológica (Biological Colonization)}

Colonização de uma rocha por micro-organismos, tais como bactérias, cianobactérias, algas, fungos e liquens (Figura 57), por musgos (Figura 58), por plantas (Figura 59), incluindo a influências de animais, como a construção de ninhos por passarinhos (Figura 60).

- Líquen (Lichen): organismo vegetal milimétrico a centimétrico, tratando-se de uma simbiose de um fungo com uma alga ou cianobactéria. Apresenta forma arredondada com cores que variam entre cinza, amarelo, laranja, verde e preto, muitas vezes apresentando aparência de couro e formando crostas espessas. Cresce geralmente na parte exterior de edifícios e monumentos.

- Musgo (Moss): organismo vegetal do grupo das briófitas, composto por microfolhas de tamanho submilimétrico e cor verde, firmamente fixas entre si, podendo atingir poucos centímetros de altura. Crescem em lugares úmidos (dependem da água para reprodução) e normalmente com sombra, como cavidades abertas na rocha.

- Planta (Plant): compreende as plantas vasculares que pertencem aos grupos das pteridófitas (samambaia), gimnospermas (pinheiros, sequoias e ciprestes) e angiospermas (feijão, milho, soja, ipê, roseira, etc). 


\section{A - FISSURA}

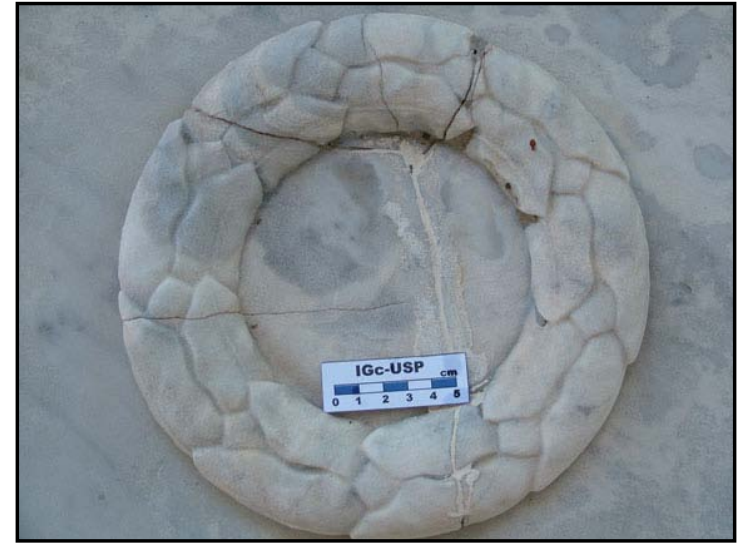

Figura 21. Fissuramento da ornamentação em mármore.

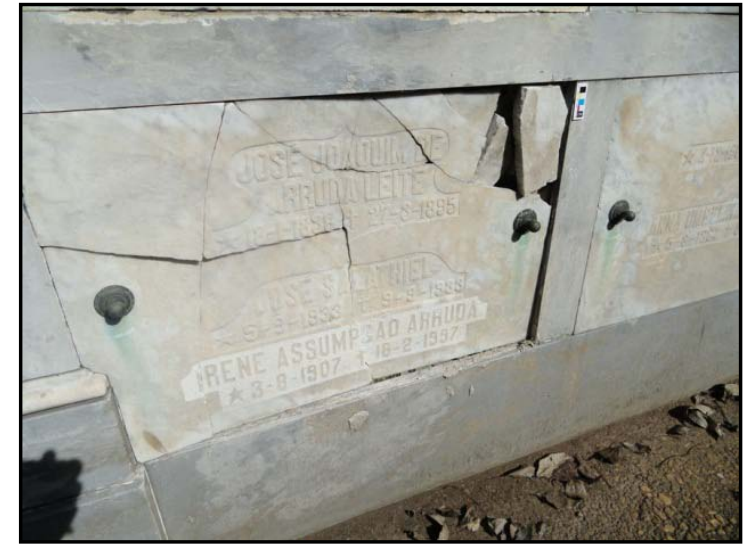

Figura 22. Fissuramento da tampa em mármore.

\section{A - DEFORMAÇÃO}

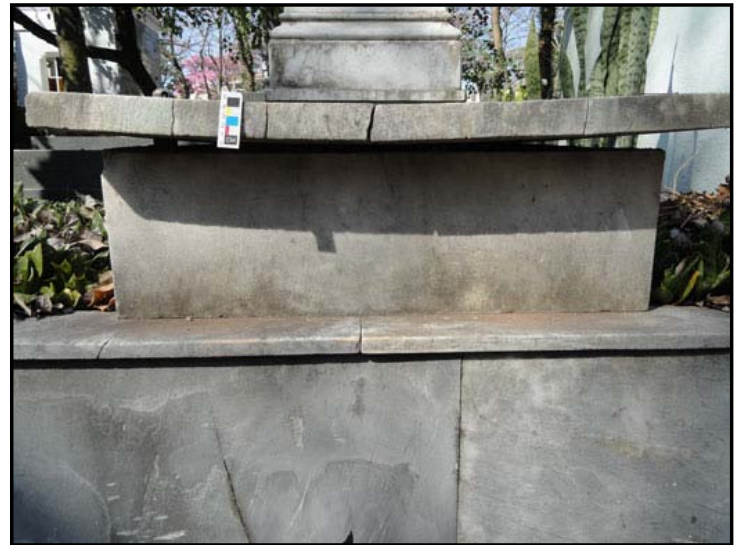

Figura 23. Deformação côncava da lápide em mármore.

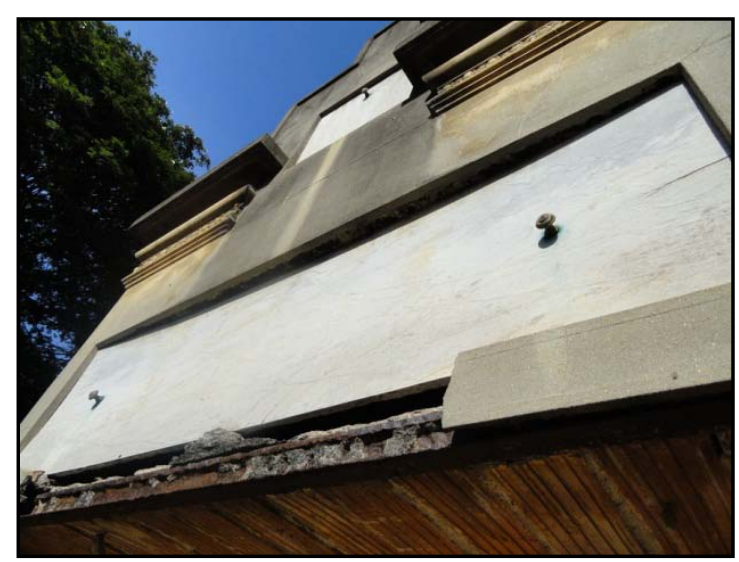

Figura 24. Deformação côncava da tampa em mármore.

\section{B - ROMPIMENTO}

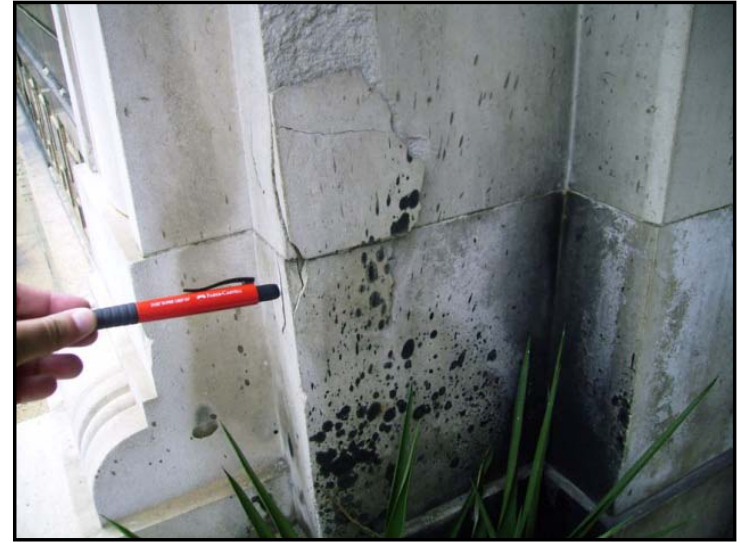

Figura 25. Início do rompimento da pilastra em calcário fossilífero (Fotografado no dia 22/01/2009).

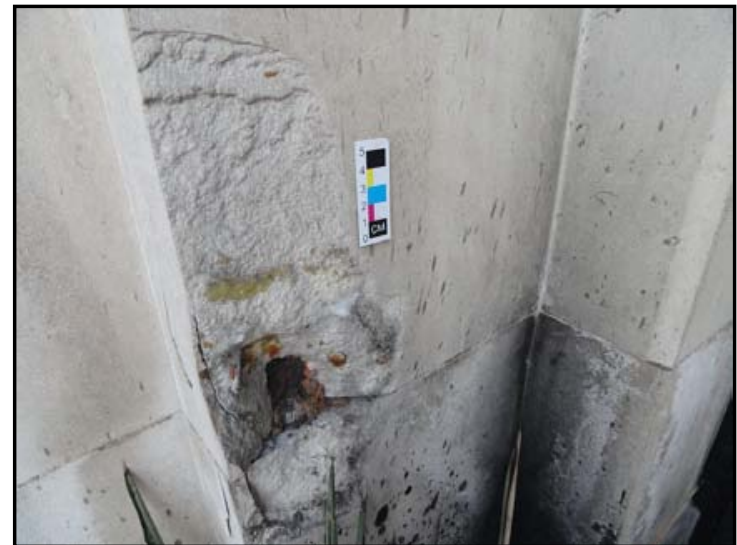

Figura 26. Após ocorrer o rompimento da pilastra em calcário fossilífero (Fotografado no dia 29/07/2011). 


\section{B - DESINTEGRAÇÃO}

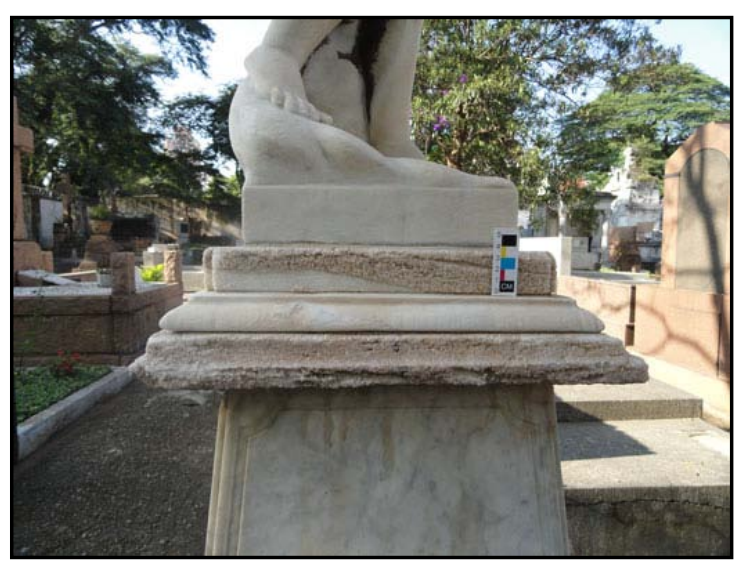

Figura 27. Desintegração do mármore tipo sugaring.

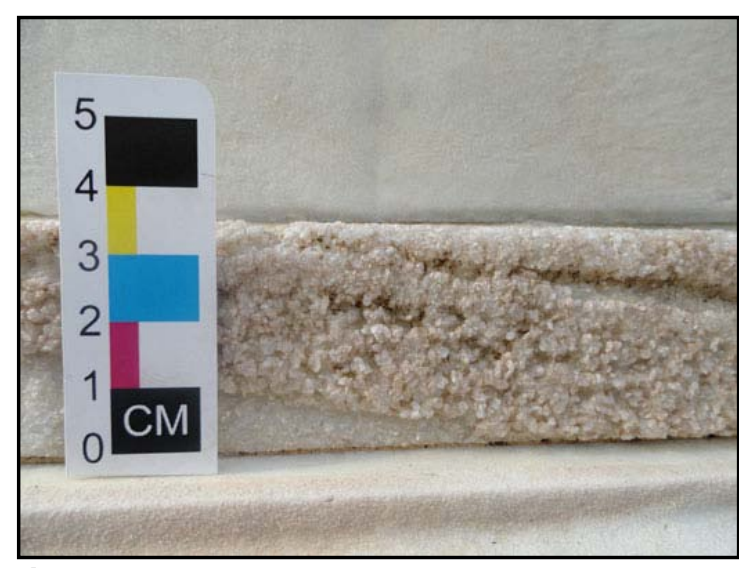

Figura 28. Detalhe da Figura 27 da desintegração do mármore.

\section{B - DESCAMAÇÃO}

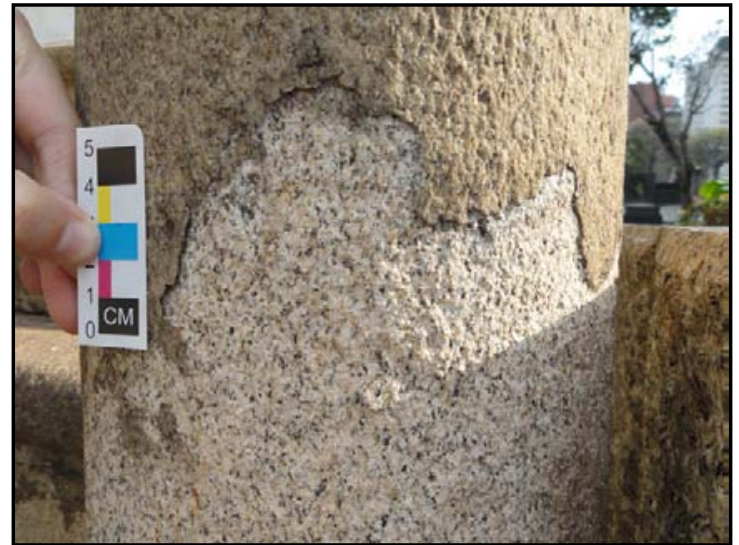

Figura 29. Descamação do Granito Itaquera.

\section{C - ALVEOLIZAÇÃO}

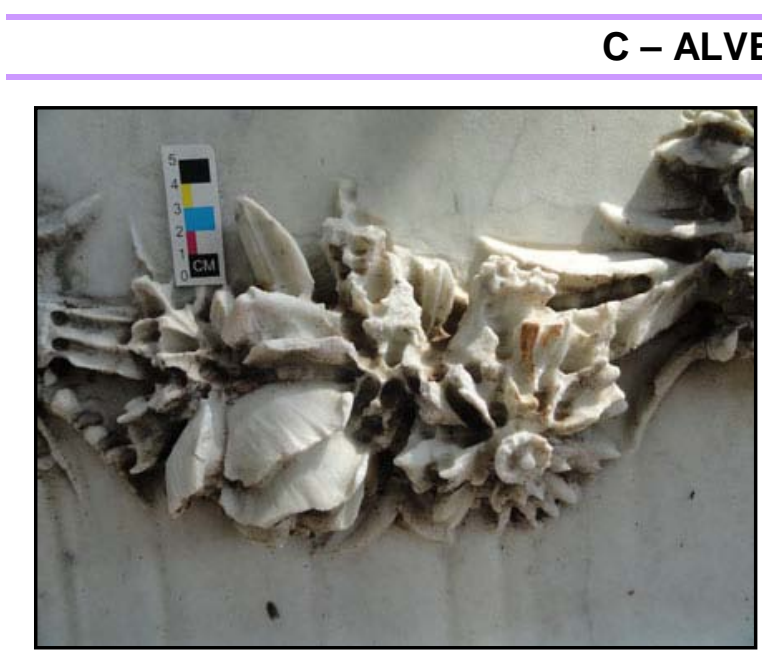

Figura 31. Alveolização do mármore.

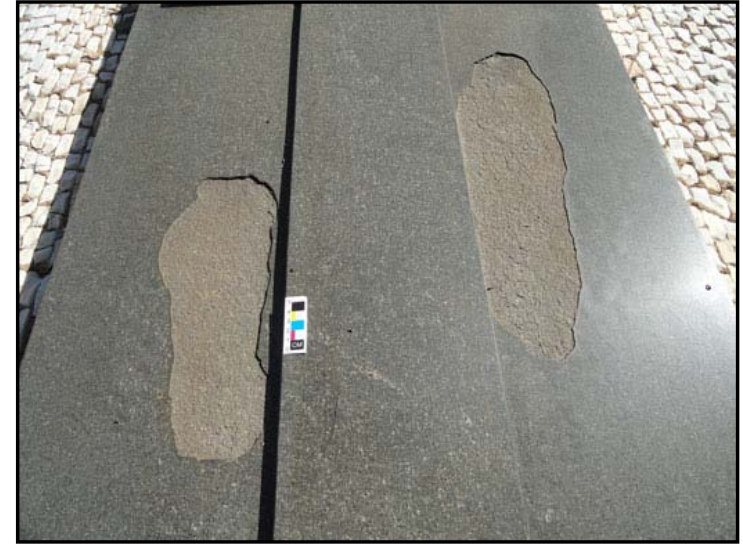

Figura 30. Descamação do Granito Preto Bragança.

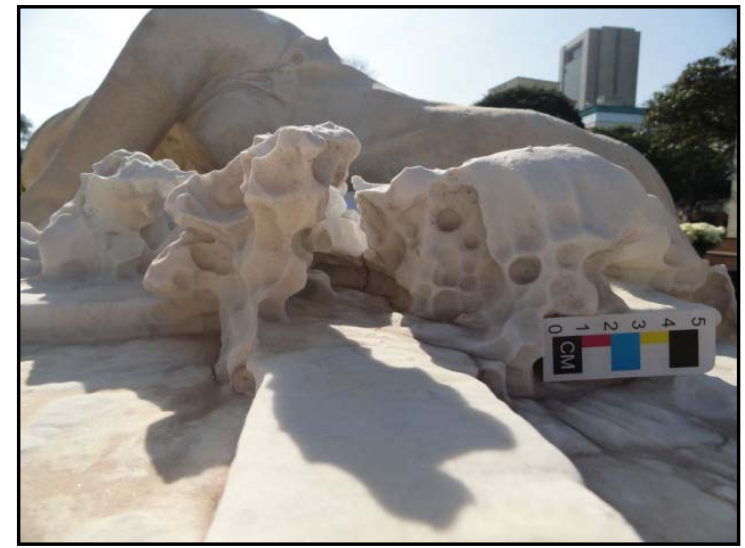

Figura 32. Alveolização do mármore. 


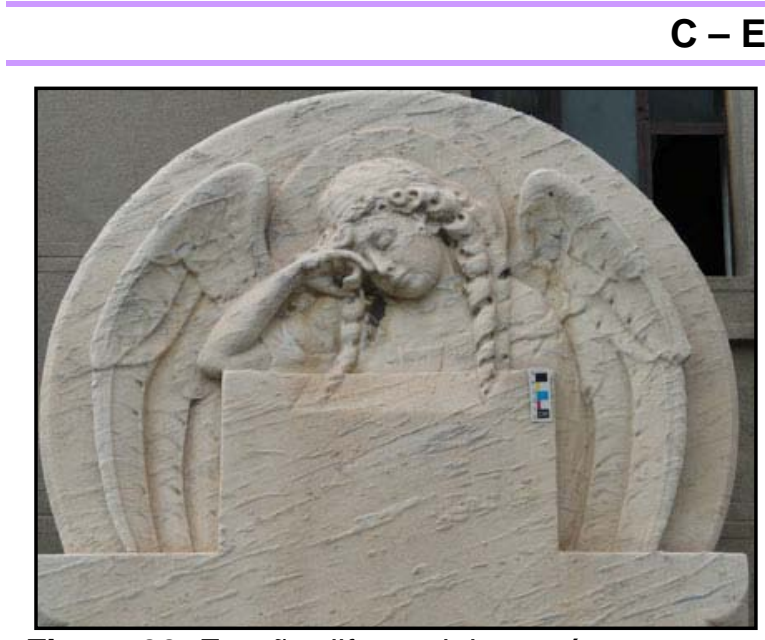

Figura 33. Erosão diferencial no mármore.

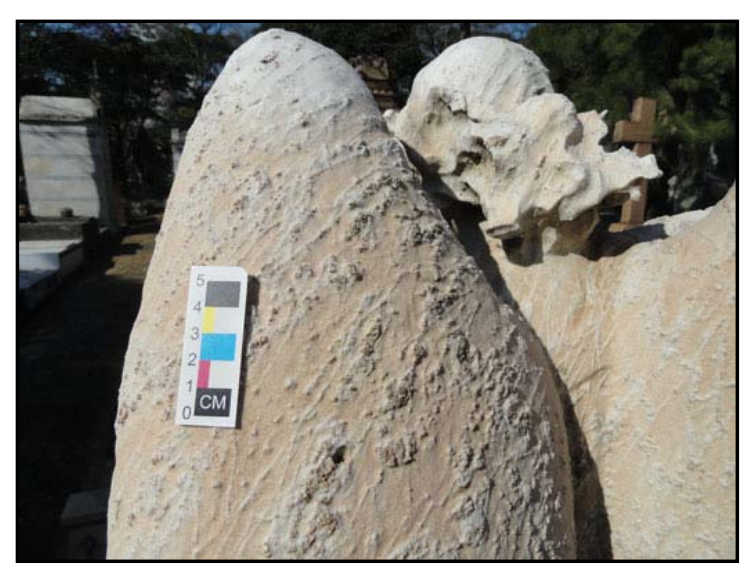

Figura 34. Erosão diferencial no mármore.

\section{C - PERDA DE PARTES}

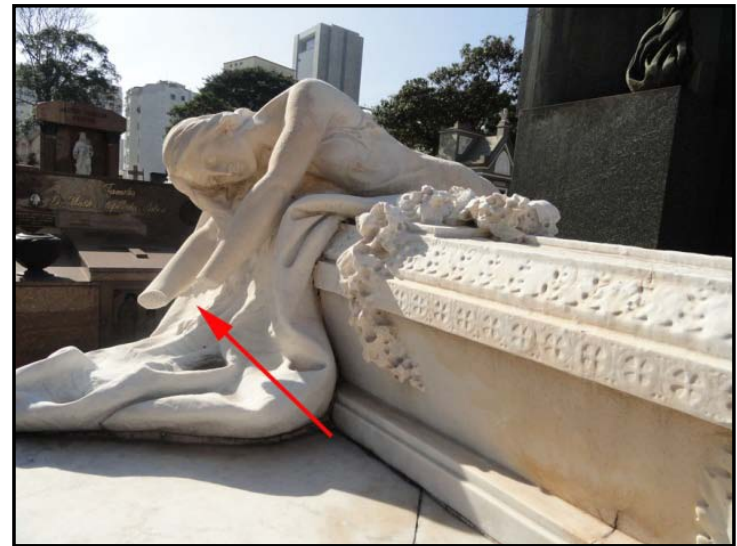

Figura 35. Perda das mãos da estátua.

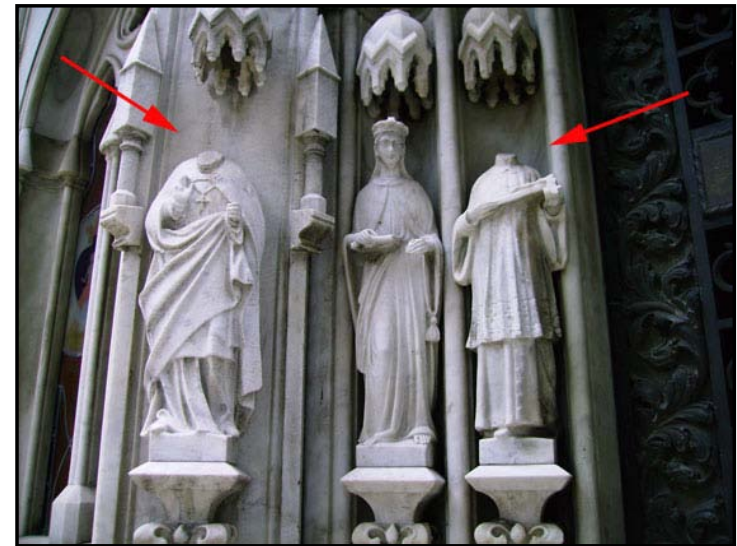

Figura 36. Perda das cabeças das estátuas.

\section{C - PERFURAÇÃO}

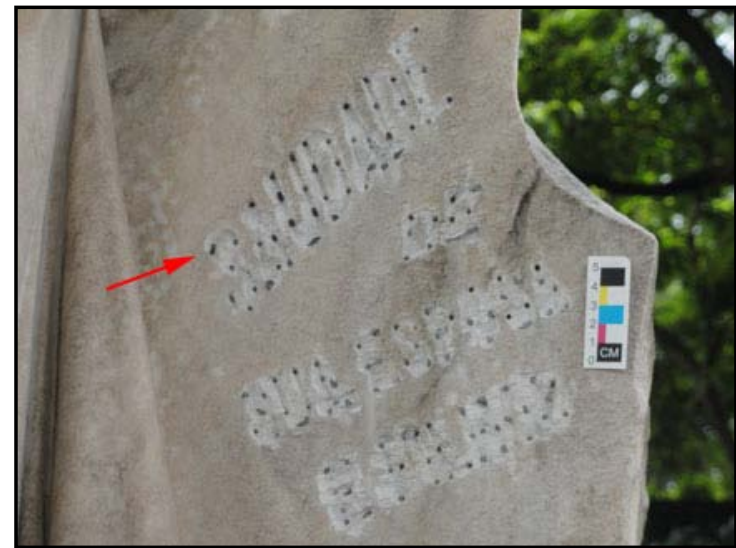

Figura 37. Perfuração da estátua em mármore.

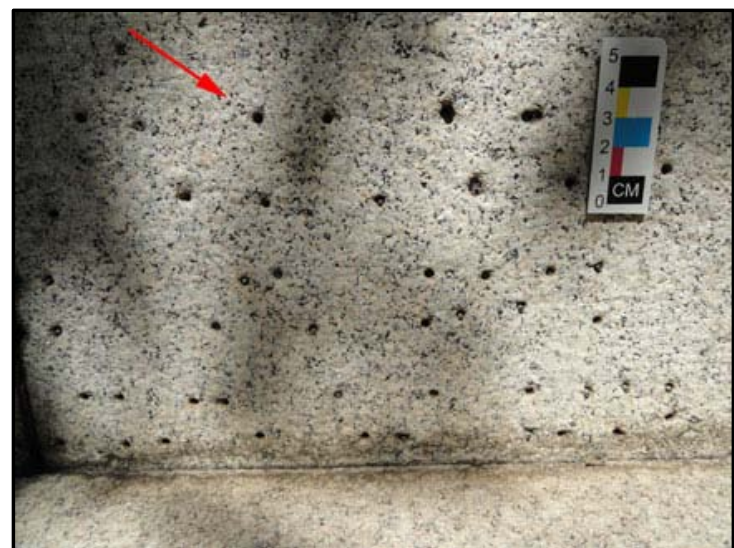

Figura 38. Perfuração do túmulo em Granito Itaquera. 


\section{D - CROSTA}

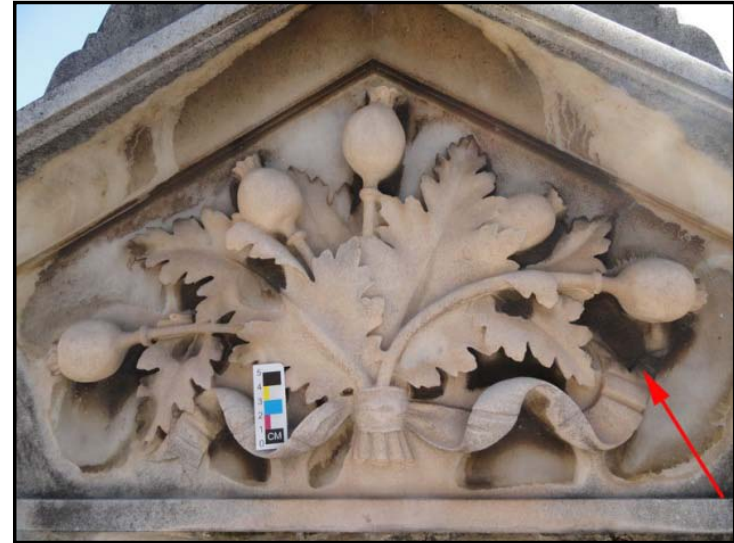

Figura 39. Crosta negra na ornamentação em mármore.

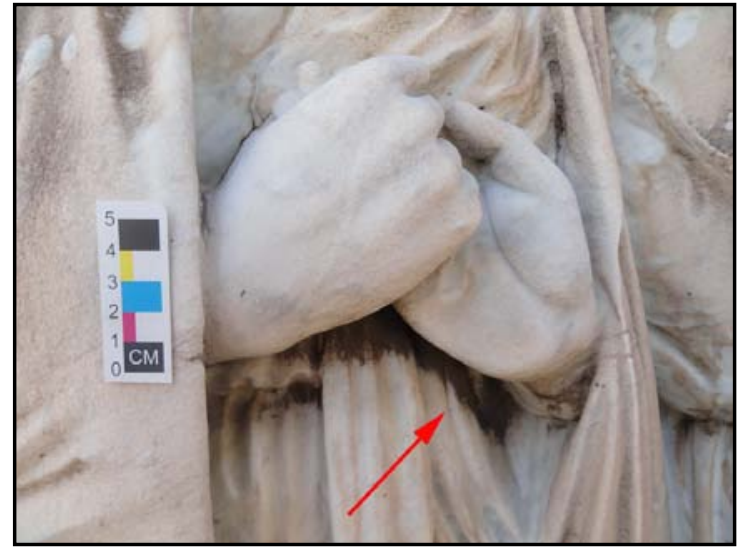

Figura 40. Crosta negra na estátua em mármore.

\section{D - DEPÓSITO}

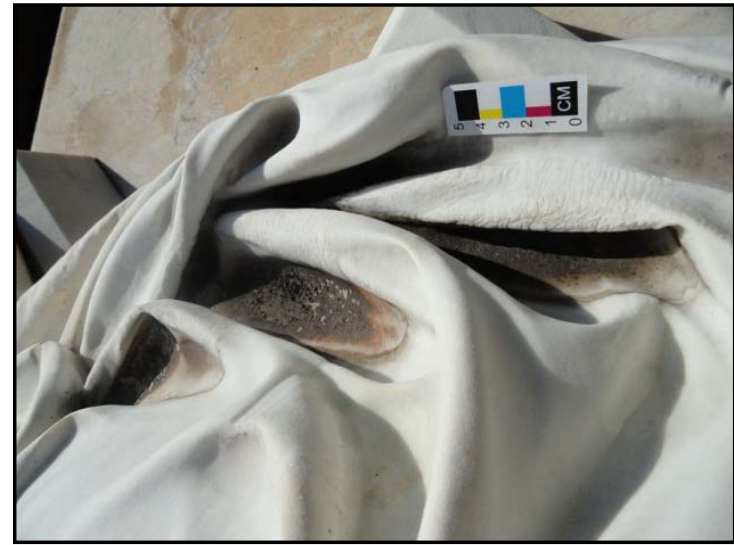

Figura 41. Depósito de fuligem no mármore.

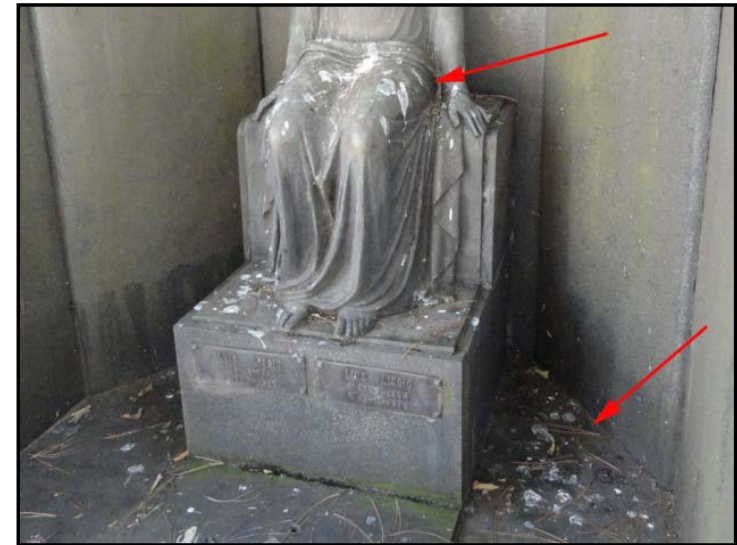

Figura 42. Depósito de fezes de pombos na estátua de bronze na tampa do túmulo em Preto Bragança.

\section{D - ALTERAÇÃO CROMÁTICA}

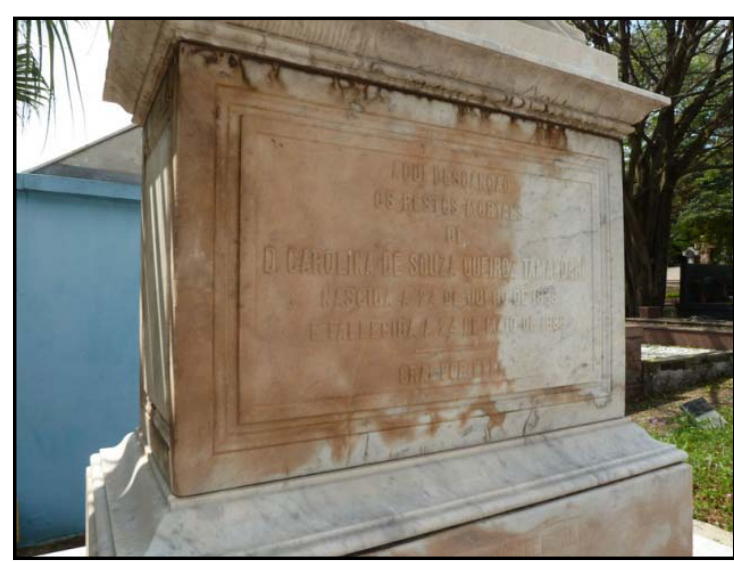

Figura 43. Alteração cromática do mármore.

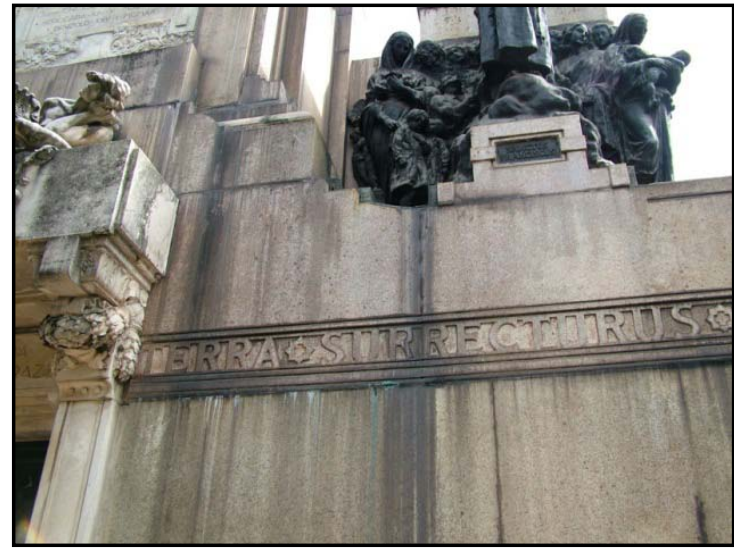

Figura 44. Alteração cromática do granito vermelho. 


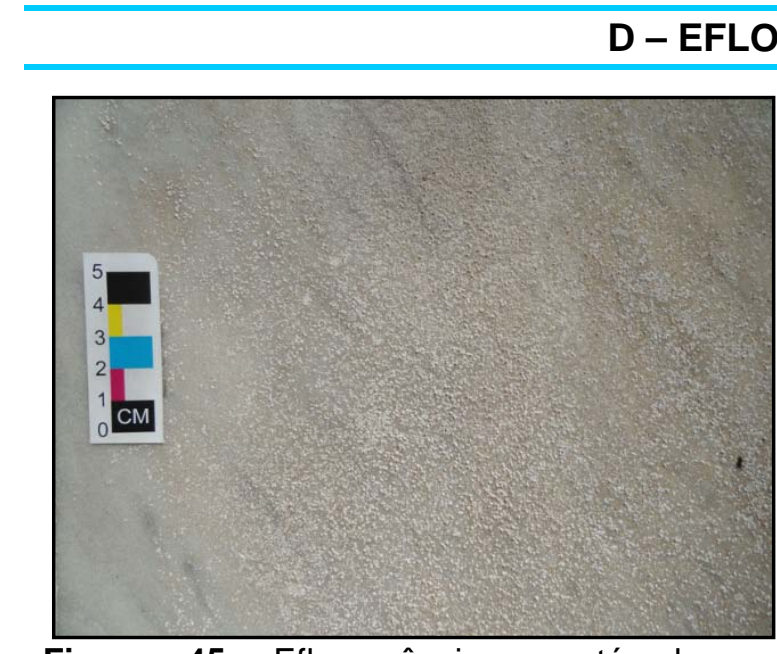

Figura 45. Eflorescência no túmulo em mármore.

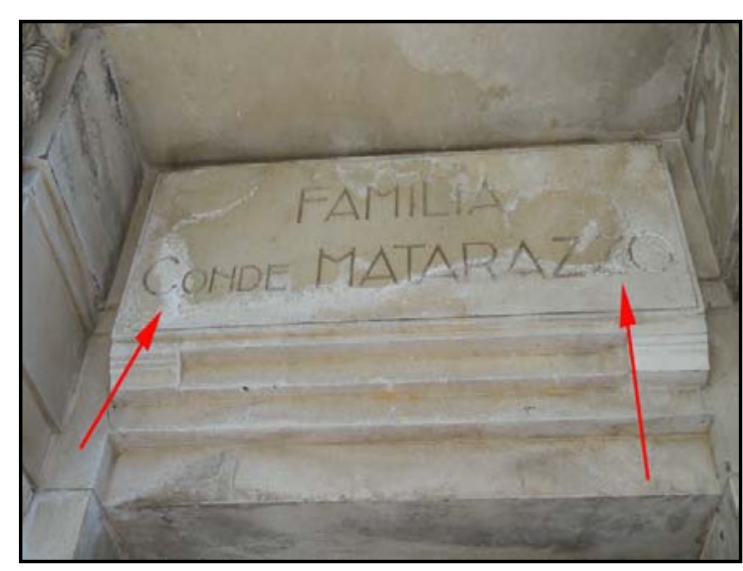

Figura 46. Eflorescência na placa de identificação em calcário fossilífero.

\section{D - INCRUSTAÇÃO}

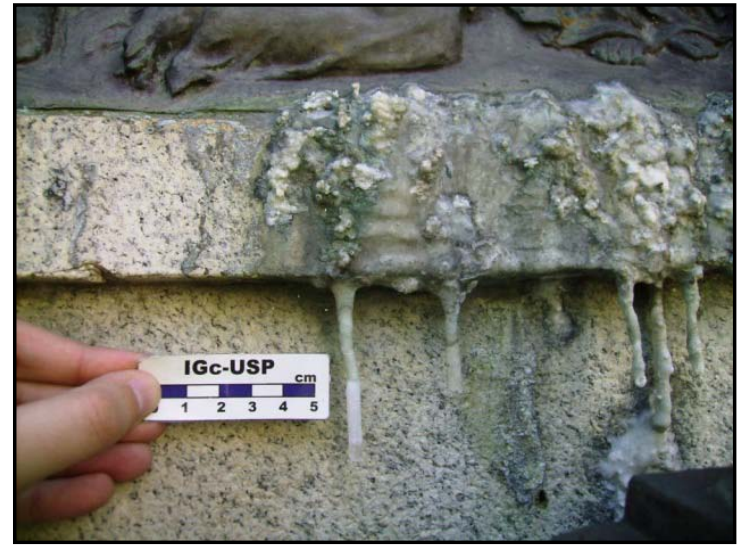

Figura 47. Concreção no túmulo em Granito Itaquera.

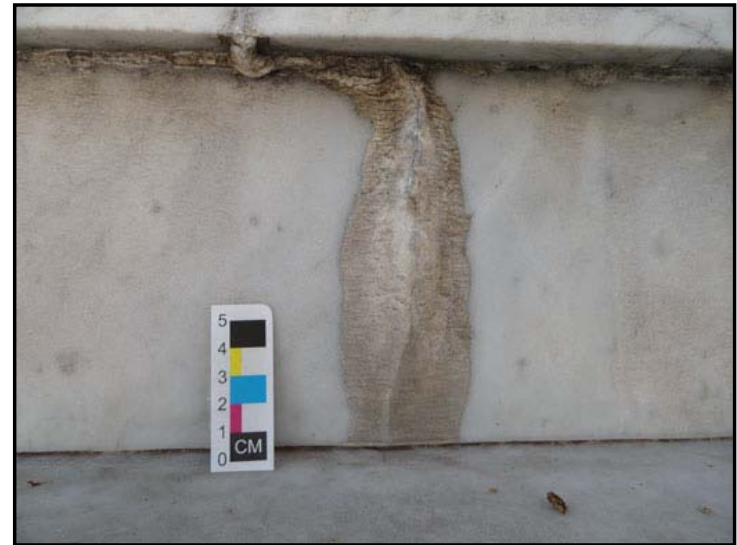

Figura 48. Concreção no túmulo em mármore.

\section{D - FILME}

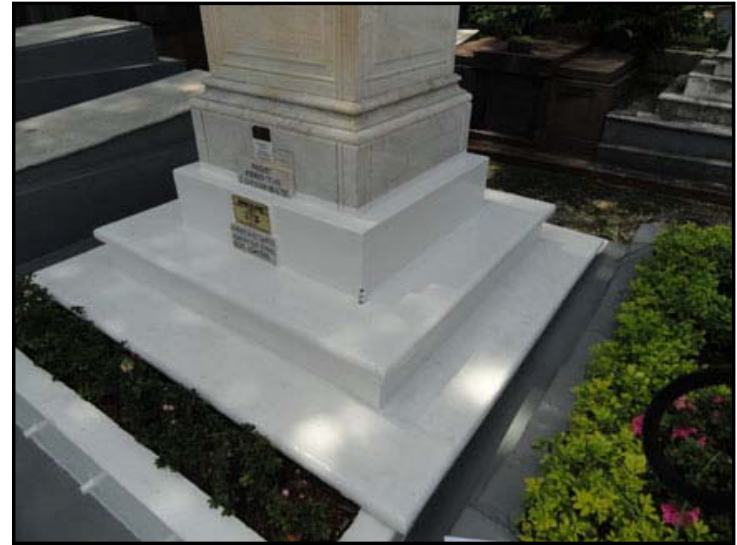

Figura 49. Aplicação de tinta no túmulo em mármore.

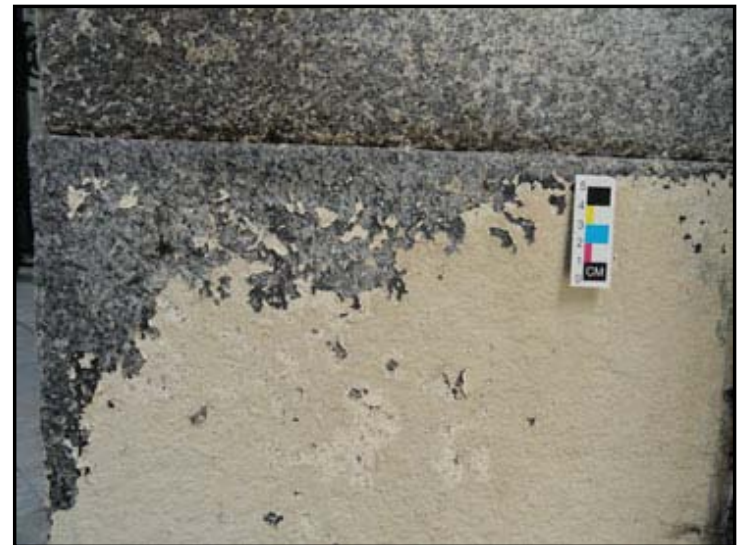

Figura 50. Aplicação de tinta no portal de entrada do cemitério em Granito Itaquera. 


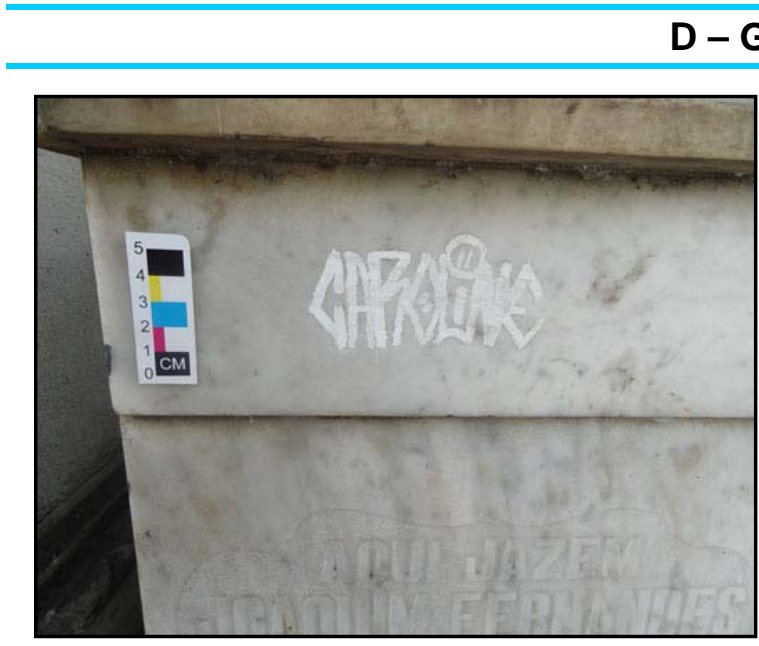

Figura 51. Grafite no túmulo em mármore.

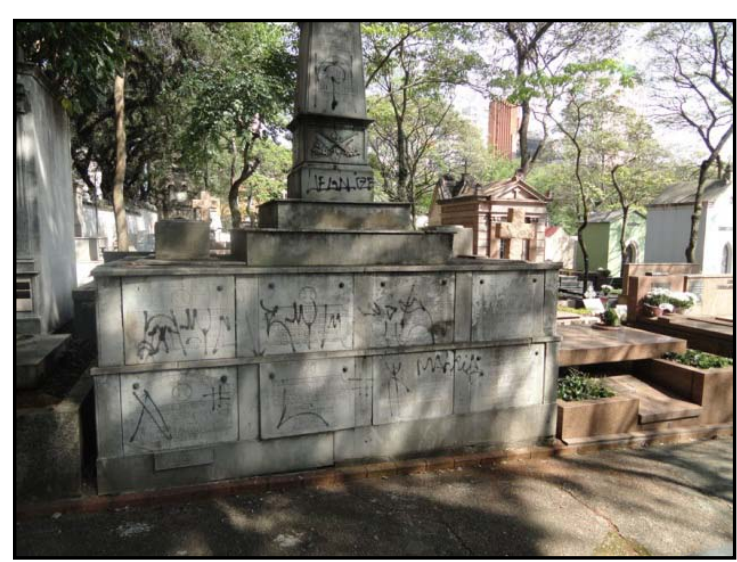

Figura 52. Grafite no túmulo em mármore.

\section{D - PATINA}

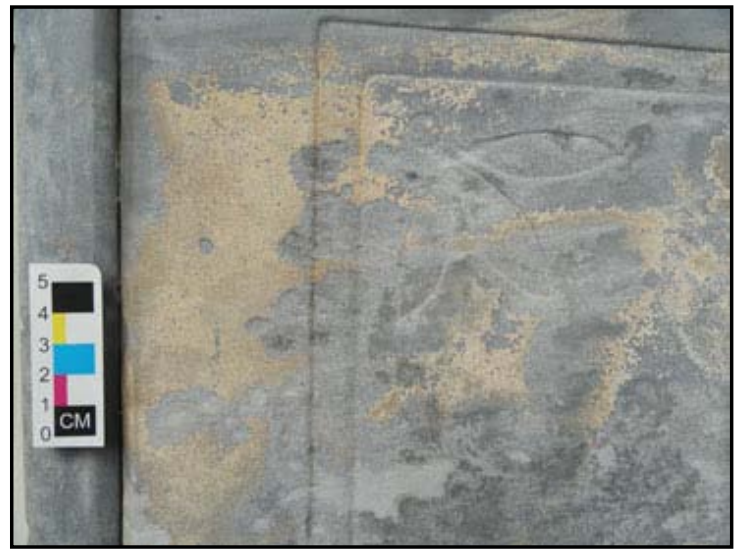

Figura 53. Patina amarelada no túmulo em mármore.

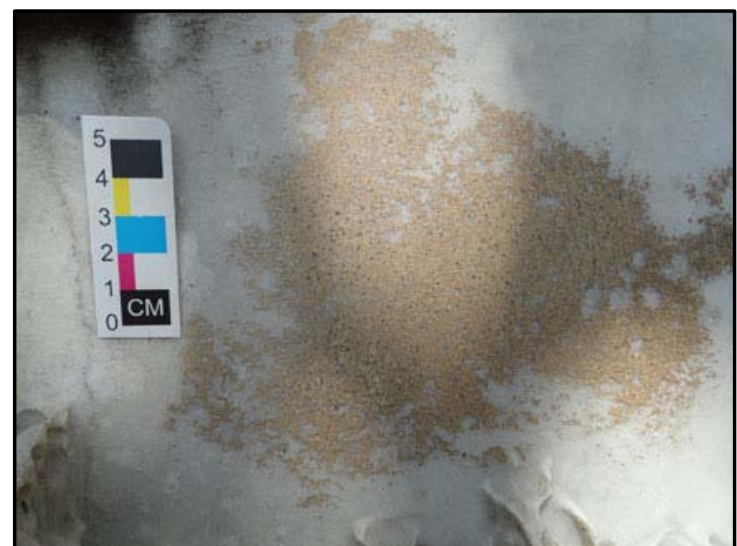

Figura 54. Patina amarelada no túmulo em mármore.

\section{D - SUJIDADE}

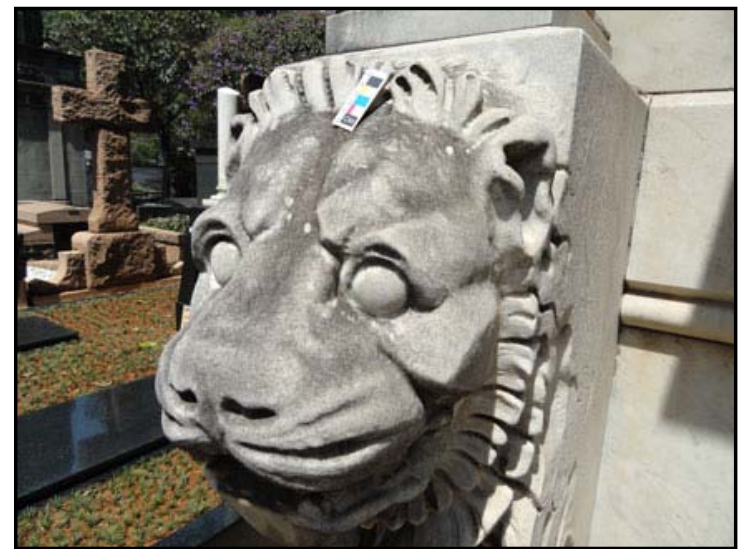

Figura 55. Sujidade na estátua em mármore.

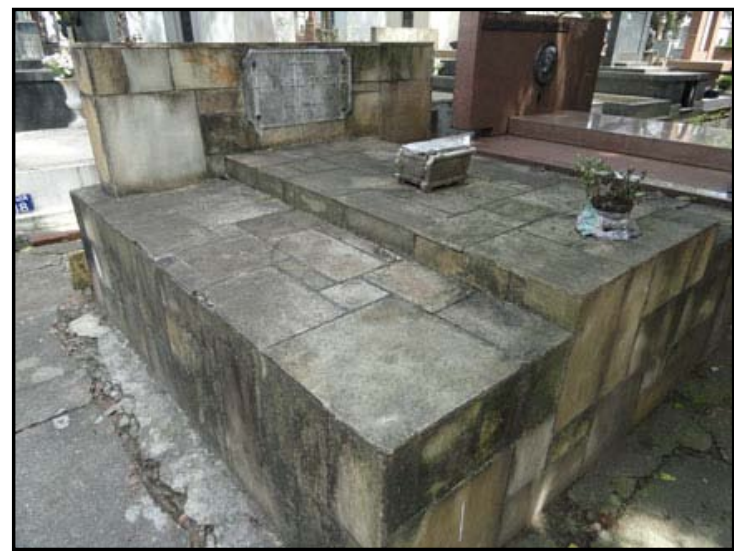

Figura 56. Sujidade no túmulo em quartzito. 


\section{E - COLONIZAÇÃO BIOLÓGICA}

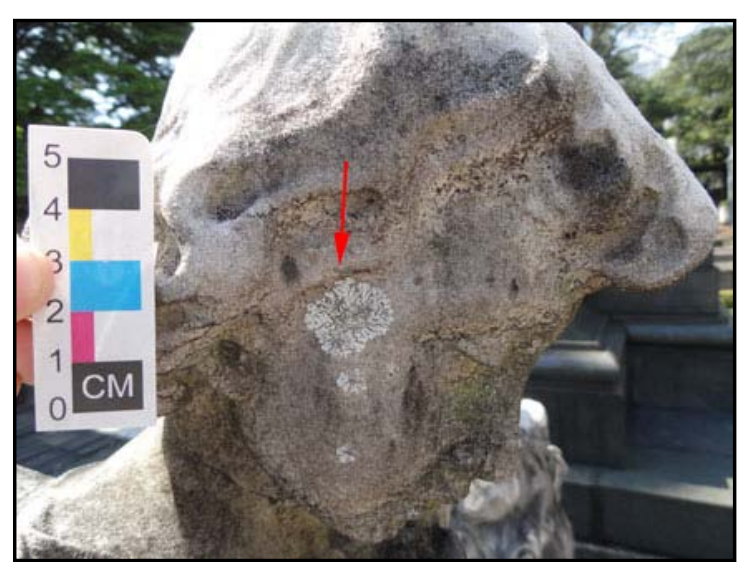

Figura 57. Colonização biológica por liquens na estátua em mármore.

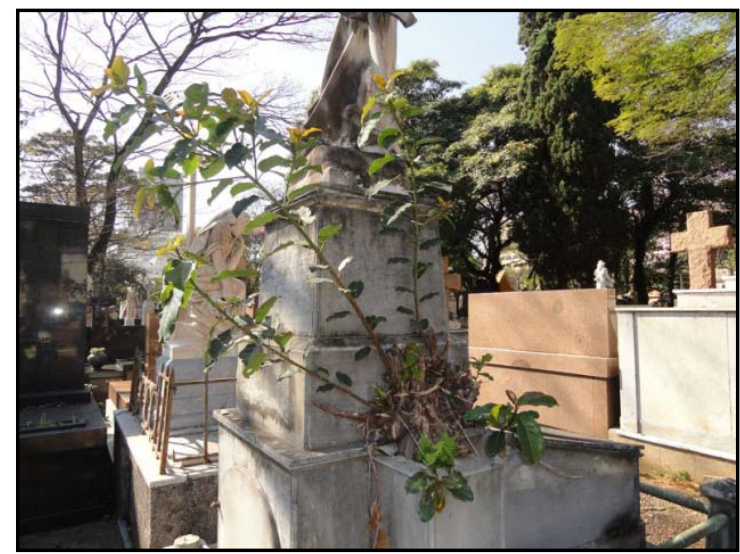

Figura 59. Colonização biológica por plantas no túmulo em mármore.

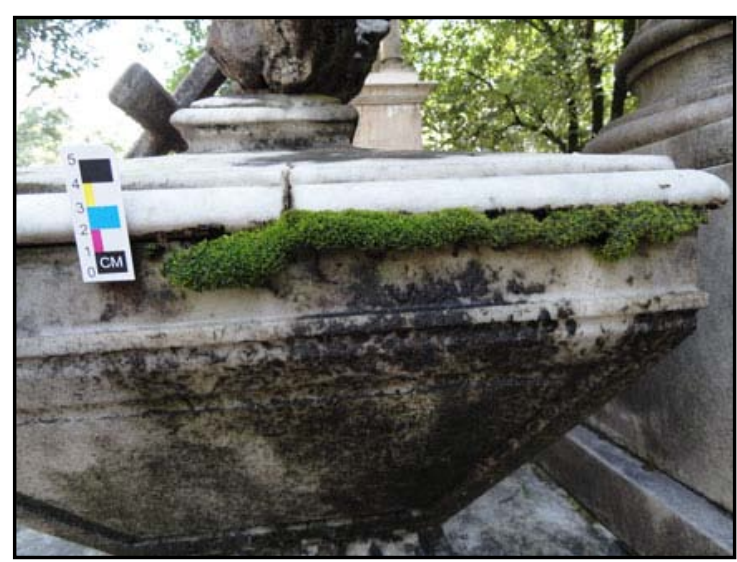

Figura 58. Colonização biológica por musgos no túmulo de mármore.

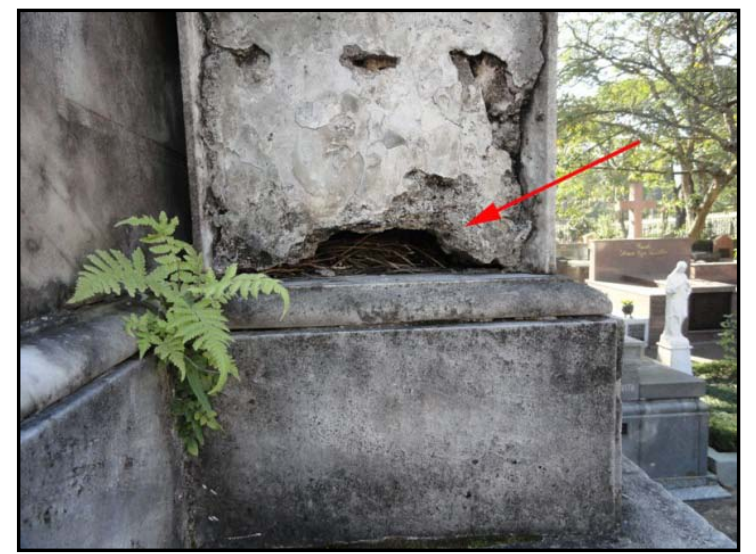

Figura 60. Ninho de pássaros no túmulo em mármore. 
A partir do mapeamento dos padrões de deterioração foi possível determinar quais litotipos estão mais degradados. De maneira geral, as rochas carbonáticas apresentam-se mais deterioradas que as rochas silicáticas e silicosas (Tabela 4).

Tabela 4. Distribuição dos padrões de deterioraçãoem função do tipo de rocha (carbonática ou silicática / silicosa).

\begin{tabular}{|c|c|c|}
\hline $\begin{array}{l}\text { Padrões de Deterioração da } \\
\text { Rocha }\end{array}$ & Rochas Carbonáticas & Rochas Silicáticas / Silicosas \\
\hline Fissura & $X$ & $X$ \\
\hline Deformação & $X$ & \\
\hline Rompimento & $X$ & \\
\hline Desintegração & $X$ & \\
\hline Descamação & $X$ & $\mathrm{X}$ \\
\hline Alveolização & $X$ & \\
\hline Erosão Diferencial & $X$ & \\
\hline Perda de Partes & $X$ & $X$ \\
\hline Perfuração & $X$ & $X$ \\
\hline Crosta & $X$ & \\
\hline Depósito & $X$ & $X$ \\
\hline Alteração Cromática & $X$ & $X$ \\
\hline Eflorescência & $X$ & \\
\hline Incrustação & $X$ & $X$ \\
\hline Filme & $\mathbf{X}$ & $\mathbf{X}$ \\
\hline Grafite & $X$ & 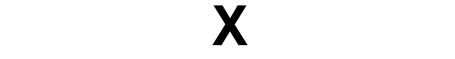 \\
\hline Pátina & $X$ & \\
\hline Sujidade & $X$ & $X$ \\
\hline $\begin{array}{l}\text { Colonização Biológica por } \\
\text { Liquens }\end{array}$ & $X$ & $\mathbf{X}$ \\
\hline $\begin{array}{l}\text { Colonização Biológica por } \\
\text { Musgos }\end{array}$ & $X$ & $X$ \\
\hline $\begin{array}{c}\text { Colonização Biológica por } \\
\text { Plantas }\end{array}$ & $X$ & $X$ \\
\hline
\end{tabular}




\subsection{COLORIMETRIA E VELOCIDADE DE PROPAGAÇÃO DAS ONDAS ULTRASSÔNICAS}

\subsubsection{FUNDAMENTOS DA COLORIMETRIA}

No dia a dia nos deparamos com infinitas cores que apresentam subjetividade na sua definição. Para identificarmos a cor de um objeto é necessária a luz, que é uma porção do espectro eletromagnético situada na região do visível, com comprimento de onda variando entre 380 a $780 \mathrm{~nm}$, distribuído da seguinte maneira: violeta, 380-440 nm; índigo, 440-460 $\mathrm{nm}$; azul, 460-490 nm; verde, 490-565 nm; amarelo, 565-590 nm; laranja, 590-630 nm; e vermelho, 630-780 nm. A luz refletida de um objeto, que reconhecemos como sendo uma cor, é (com exceção da luz monocromática criada pelo homem) a mistura e a variação da intensidade dos diversos comprimentos de onda dentro da região visível.

Basicamente, a cor é o resultado da mistura da tonalidade, luminosidade e saturação, sendo esses atributos influenciados por diferenças na fonte de luz, diferenças no observador, diferenças no tamanho dos objetos, diferenças no fundo a qual o objeto está diante e diferenças nas visadas do objeto.

A colorimetria foi criada justamente para acabar com a subjetividade, exprimindo valores as cores. Esse termo foi empregado pela primeira por volta da década de 1860 por químicos, quando se referiam a utilização da cor dos líquidos para determinar a concentração das substâncias químicas que eles continham (Johnston, 1996).

Foram criadas muitas escalas para quantificar numericamente as cores, a primeira delas foi desenvolvida em 1905, por A. H. Munsell, que classificou as cores de pastilhas de papel colorido de acordo com a sua tonalidade (Munsell Hue), Luminosidade (Munsell Value) e saturação (Munsell Chroma). Posteriormente, esse sistema foi atualizado, criandose o Sistema de Notação Munsell, utilizado até os dias de hoje.

A CIE, ou Commission Internationale de L'Eclairage (Comissão Internacional de Iluminação) é o órgão responsável pelas recomendações internacionais para colorimetria e fotometria. Em 1931 a CIE padronizou os sistemas de cores pela especificação dos iluminantes (representação gráfica do recurso de luz utilizado para visualizar a amostra, abrangendo vários tipos, entre eles: lluminante padrão A - Luz incandescente com temperatura de cor de 2856K; lluminante padrão D65 - Média da luz do dia, incluindo a região de comprimentos de onda ultravioleta, com temperatura de cor de 6504K; lluminante fluorescente F2 - Branco frio), do observador padrão (representa a resposta do olho humano aos diferentes comprimentos de ondas da luz visível, podendo ser o observador padrão de $2^{\circ}$, determinado em 1931 , ou o de $10^{\circ}$, determinado em 1964 ) e a metodologia 
utilizada para obter os valores para descrever a cor. A CIE utiliza três espaços de cores para identificar numericamente a cor, sendo eles: CIE XYZ, CIE L*a*b* e CIE $L^{*} C^{*} h^{\circ}$.

O espaço de cores CIE XYZ, criado em 1931, baseia-se nos valores tristímulos XYZ, que são obtidos pela multiplicação dos valores dos comprimentos de onda da luz visível refletidos por um objeto (curva espectral), pelos dados espectrais do iluminante padrão e do observador padrão utilizados. Infelizmente, os valores tristímulos possuem um uso limitado, pois as variações das cores no diagrama de cromaticidade não correspondem as modificações visuais das cores estudadas.

Devido às limitações do diagrama de cromaticidade, a CIE criou duas novas escalas, a CIE $1976\left(\mathrm{~L}^{*} \mathrm{a}^{*} \mathrm{~b}^{\star}\right)$ ou CIELAB e a CIELCh $\left(\mathrm{L}^{*} \mathrm{C}^{*} \mathrm{~h}^{\circ}\right)$. Tanto o CIELAB como o CIELCh são espaços de cor aproximadamente uniformes, ou seja, os pontos plotados no diagrama de cromaticidade correspondem às diferenças visuais entre as cores estudadas. A grande diferença entre esses espaços é que o CIELAB utiliza coordenadas retangulares, enquanto o CIELCh utiliza coordenadas cilíndricas. Os diagramas dos espaços de cores estudados são apresentados abaixo (Figuras 61 e 62).

\section{CIELAB}

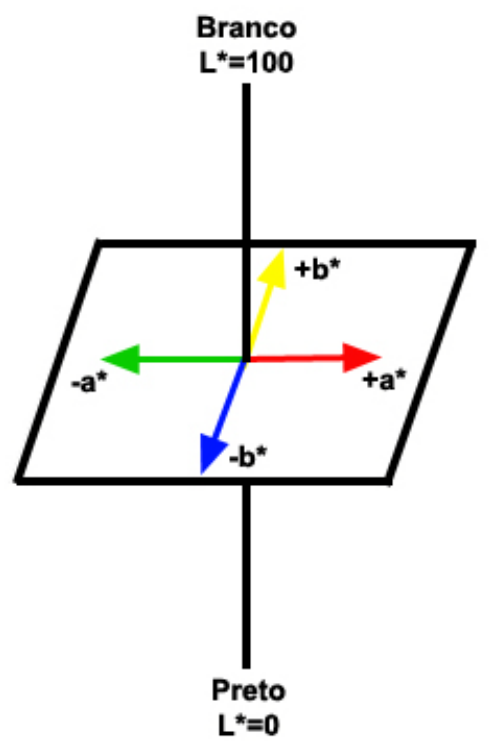

Figura 61. Espaço de cor CIELAB.

\section{CIELCh}

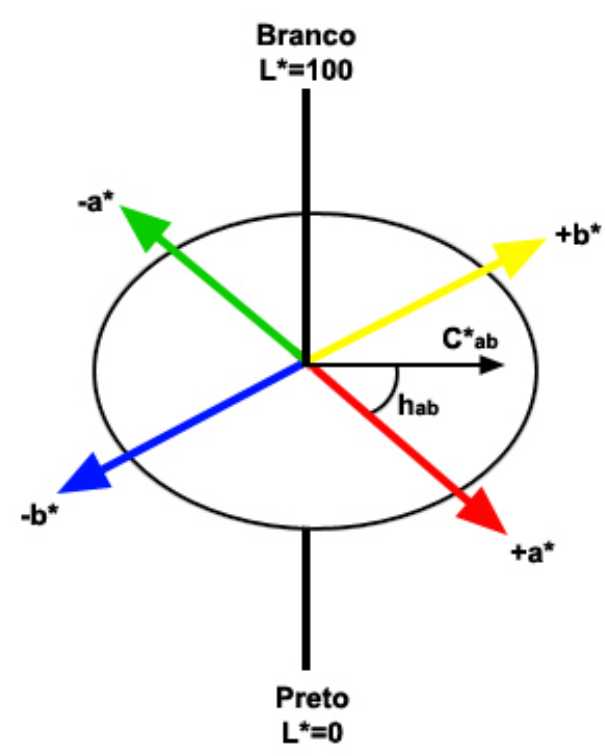

Figura 62. Espaço de cor CIELCh.

O eixo $L^{*}$, que representa a luminosidade, é o mesmo para os dois espaços de cor. $O$ valor máximo para o $L^{*}$ é 100 , que representa um difusor de reflexão perfeito, ou seja, corresponde ao branco, enquanto o valor mínimo é zero, que corresponde ao preto, o centro do eixo é acromático. 
No caso do CIELAB os eixos $\mathrm{a}^{*} \mathrm{e} \mathrm{b}^{*}$, cromacidade, apresentam limites numéricos específicos que variam de -60 a 60 . O limite positivo de $a^{\star}$ é vermelho enquanto o limite negativo é verde, e o limite positivo de $b^{\star}$ é amarelo e o negativo azul.

O CIELCh utiliza as coordenadas polares $\mathrm{C}^{\star}{ }_{\mathrm{ab}}$, croma, e $\mathrm{H}_{\mathrm{ab}}$, ângulo de tonalidade, calculadas a partir dos valores de $a^{*} e b^{*}$ do CIELAB. O valor de $C^{*}{ }_{a b}$ é zero no centro do diagrama de cromacidade e aumenta conforme aumenta a distância deste, podendo variar até 60. $\mathrm{O}$ valor do $\mathrm{H}_{\mathrm{ab}}$ é dado em graus, sendo que $+\mathrm{a}^{\star}$ (vermelho) é $0^{\circ},+\mathrm{b}^{\star}$ (amarelo) é $90^{\circ}$, -a* (verde) é $180^{\circ}$ e - $b^{\star}$ (azul) é $270^{\circ}$.

O cálculo da variável $L^{*}$, luminosidade, e das coordenadas de cromaticidade $a^{\star}$ e b*, é realizado por meio de equações matemáticas que utilizam os valores tristímulos $X Y Z$. Os valores dos parâmetros $L^{*}, a^{\star}$ e $b^{\star}$ são calculados automaticamente pelo espectrofotômetro.

Os valores do croma $\mathrm{C}^{*}$ e do ângulo de tonalidade $\mathrm{H}_{\mathrm{ab}}$ são calculados pelas seguintes equações (Equações 1 e 2):

$$
C * \sqrt{\left(a^{*}\right)^{2}+\left(b^{*}\right)^{2}}
$$

Equação 1. Croma.

$$
H^{\circ}=\tan ^{-1}\left\{\frac{a^{\star}}{b^{\star}}\right\}
$$

Equação 2. Ângulo de tonalidade.

Em relação ao CIELAB existem ainda os valores dos deltas, que indicam o quanto um padrão e uma amostra diferem entre si. Esses valores são dados pelas seguintes equações (Equações 3, 4 e 5):

$$
\Delta L^{*}=L_{\text {final }}{ }^{*}-L_{\text {inicial }}{ }^{*} \quad \Delta a^{*}=a_{\text {final }}{ }^{*}-a_{\text {inicial }}{ }^{*}
$$

Equação 3. Diferença entre o padrão e a Equação 4. Diferença entre o padrão e a amostra para a luminosidade. amostra para a cromacidade a.

$$
\Delta b^{\star}=b_{\text {final }}^{\star}-b_{\text {inicial }}{ }^{*}
$$

Equação 5. Diferença entre o padrão e a amostra para a cromacidade b. 
$\mathrm{O} \Delta \mathrm{E}$ indica a difereça total de uma cor, entretanto não sua direção, podendo ser calculado pela seguinte equação (Equações 6):

$$
\Delta E *=\sqrt{(\Delta L *)^{2}+\left(\Delta a^{*}\right)^{2}+\left(\Delta b^{*}\right)^{2}}
$$

Equação 6. Diferença total da cor.

Existem ainda outro valor de delta, relacionado ao CIELCh que pode ser calculado pela seguinte equação (Equação 7):

$$
\Delta C^{*}=C_{\text {final }}{ }^{*}-C_{\text {inicial }}{ }^{*}
$$

Equação 7. Diferença entre o padrão e a amostra para o croma.

A avaliação colorimétrica pode ser realizada pelo colorímetro ou pelo espectofotômetro. Os colorímetros geralmente utilizam o método tristímulos, que mede as características espectrais da luz, de maneira análoga ao sistema visual humano, consistindo de três sensores que simulam a resposta dos cones do olho humano, calculando os valores tristímulos com base em equações que utilizam as funções dos Observadores Padrão CIE e com a especificação da lluminação Padrão, com os resultados numéricos gerados em um dos modelos padronizados de cores CIE. O espectrofotômetro, entretanto, mede a reflectância do objeto estudado em cada comprimento de onda da região do visível, fornecendo além dos valores numéricos, o gráfico de reflectância espectral da cor.

Existem duas maneiras de medir a cor, a que mede a reflectância total (reflectância especular mais a reflectância difusa) e a que exclui a reflectância especular. Quando a luz incidente em um plano é refletida com o mesmo ângulo, entretanto com direção oposta é chamada de luz especular refletida, a luz refletida em qualquer outro ângulo é chamada luz difusa. Em superfícies brilhantes (por exemplo, rochas ornamentais polidas) a reflectância especular é mais forte que a difusa, em superfícies rugosas, com pouco brilho (rochas ornamentais não polidas), a componente difusa é mais forte que a especular (X-Rite, 2007).

A aplicação dos colorímetros é muito ampla, podendo ser utilizados, por exemplo, para o controle de qualidade da cor na linha de produção de materiais impressos, produtos têxteis e plásticos. Vários trabalhos exemplificam a aplicação de colorímetros, entre eles: 
- Gonçalez et al. (2001) mostraram que a colorimetria quantitativa pode ser utilizada para a determinação da cor da madeira, principalmente para espécies tropicais. Enfatiza a importância da utilização desta técnica na indústria madeireira, onde o emprego da madeira para a fabricação de móveis, assoalhos ou outras formas de utilização interiores são determinados principalmente pela cor.

- Autran e Gonçales (2006) determinaram as cores de madeiras de muirapiranga e de seringueira, concluindo que ambas podem ser utilizadas em interiores, além de confirmar a eficácia da colorimetria na determinação da cor de madeiras.

- Souza et al. (2010) estudaram a resistência natural e alteração da cor da madeira de jacarandá caviúna após exposição a determinados fungos, concluindo-se que a espécie apresenta elevada resistência natural ao ataque de fungos apodrecedores, mantendo-se o padrão de cor apesar da alteração dos parâmetros colorimétricos.

- Atayde et al. (2011) avaliou as características colorimétricas das três seções anatômicas (transversal, tangecial e radial) da madeira muitapiranga, concluindo diferenças significativas nos parâmetros colorimétricos para as três seções estudadas, permitindo a formação de lotes de madeira com a mesma tonalidade.

- Lopes e Frota (2009) estudaram as dificuldades na gestão da cor no processo de estamparia digital têxtil, em relação a sua reprodução a partir do desenho do programa do computador e sua uniformidade no produto. A partir do estudo dos parâmetros colorimétricos foi possível concluir que a impressora digital têxtil é valida para a aplicação a que se destina, apresentando boa uniformidade e repetitividade da cor, nas amostras analisadas.

- Rigueira (2005) analisou o efeito da radiação solar sobre a qualidade do café sob diferentes condições de secagem e armazenagem. Considerando que os grãos esbranquiçados apresentam menor qualidade, foram determinados os parâmetros colorimétricos do tipo de café estudado que indicou que os grãos secos sem exposição direta à radiação solar global, apresentam menor taxa de branqueamento durante a armazenagem e produzem cafés de melhor qualidade.

- Botelho et al. (2006) compararam a cor de diferentes solos do Rio Grande do Sul, determinadas pela carta de Munsell e por colorimetria, tentando correlacioná-las com os atributos do solo. Nas conclusões afirmam a eficiência do uso da colorimetria na obtenção de informações do solo, de maneira simples e de baixo custo.

- Machado et al. (1997) empregaram a colorimetria no controle de qualidade de superfícies vidradas de revestimentos cerâmicos, sendo usada como indicativo de variabilidade no processo produtivo.

- Santos et al. (2006) sintetizaram pigmentos amarelos de $\mathrm{TiO}_{2}-\mathrm{xCeO}_{2}(\mathrm{x}=2 ; 6 ; 10 ; 13$ e $17 \mathrm{~mol} \%$ ) para aplicação em cerâmicas dentais. A aquisição de coordenadas 
colorimétricas possibilitou a caracterização da cor amarela dos pigmentos, verificando o potencial de utilização destes pigmentos em cerâmicas dentais, pois foi possível imitar a cor de dentinas odontológicas comerciais, obtendo-se valores de $\Delta \mathrm{E}^{*}$ dentro daqueles clinicamente aceitáveis.

- Santos (2006) sintetizou óxidos de cério puro e dopado com praseodímio e óxidos mistos de titânio e cério para aplicação como pigmentos cerâmicos. Pela colorimetria foi comprovada a utilização dos pigmentos em restaurações dentais, sendo que revestimentos contendo os pigmentos de óxidos de titânio-cério apresentaram tonalidades similares àquelas de dentinas comerciais.

- Della et al. (2008) propuseram a síntese do pigmento cerâmico verde vitória, que apresenta um tom verde difícil de ser obtido e reproduzido, além de ser sensível aos componentes do esmalte (principalmente aqueles com óxido de zinco) e a oscilações de temperatura durante o processo de queima. Os parâmetros colorimétricos obtidos indicam acentuada diferença cromática entre o pigmento comercial e o sintetizado, entretanto as tonalidades desenvolvidas pelos pigmentos quando aplicados no esmalte foram similares.

- Schabbach (2004) estudou a eficiência do uso da espectrofotometria, juntamente com o modelo de Kubelka-Munk (permite relacionar a cor do esmalte obtido com a concentração dos pigmentos adicionados), na predição das cores de esmaltes cerâmicos opacos.

- Andrade et al. (2005) estudaram a cor de porcelanas odontológicas obtidas a partir de matérias-primas nacionais, utilizando pigmentos e composições de fritas compostas essencialmente por feldspato. Concluiram que o revestimento cerâmico estudado apresenta um padrão colorimétrico similar à amostra padrão, camada de dentina utilizada nas restaurações dentárias.

- Silva et al. (2007) estudaram a perda de cor de ágatas tingidas artificialmente, considerando diferentes ambientes de exposição e métodos de tingimento.

- Maccari Neto (2009) estudou a influência das variáveis do processo de fabricação de revestimentos cerâmicos na ocorrência do fenômeno de metamerismo (possibilidade de duas peças serem da mesma cor sob a luz do dia, mas de cores distintas sob outra iluminação).

Em relação à área de conservação de monumentos, a colorimetria pode ser empregada de várias maneiras, por exemplo: para avaliar a modificação da cor original de uma rocha pela aplicação de consolidantes, antigrafiti, hidrofungantes, biocidas, etc; avaliar a sintonia cromática (ou a falta dela) entre materiais originais e os que foram acrescentados; avaliar o quanto a cor de uma rocha se modificou devido a ação dos agentes intempéricos, como poluição, biocolonização, chuva ácida, etc. Nesse contexto muitos trabalhos foram publicados, entre eles: 
- Costa e Delgado Rodrigues (1996) apresentaram uma metodologia para avaliar as mudanças cromáticas, induzidas pela aplicação de determinados tratamentos, em rochas graníticas.

- Delgado Rodrigues e Costa (1996) avaliaram os aspectos negativos da aplicação de consolidantes em um determinado tipo de rocha granítica encontrada próxima a cidade de Évora, Portugal. Entre os parâmetros nocivos foram estudadas as coordenadas colorimétricas, indicando que determinados produtos promovem o escurecimento e amarelamento da cor da rocha.

- Ferreira Pinto et al. (1996a e b) avaliaram a eficácia e a nocividade de quatro tipos de repetentes de água quando aplicados a rochas graníticas submetidas a ensaios de intemperismo acelerado. Em relação aos aspectos nocivos foram estudados os parâmetros colorimétricos $a^{*}$ e $b^{\star}$, que ajudaram a concluir que não ocorreram modificações significativas na cor original da rocha, devido à aplicação dos produtos.

- Iñigo et al. (1997) estudaram a variação da cor de cinco tipos de granitos utilizados nas construções históricas da cidade de Ávila (Espanha), quando submetidos a tratamentos com consolidantes e/ou hidrofugantes.

- García-Talegon et al. (1998) estudaram as mudanças cromáticas que ocorreram em um tipo de arenito muito utilizado nas construções históricas da cidade de Salamanca, Espanha, devido ao tratamento com consolidantes e/ou hidrofugantes e por ciclos artificiais de aquecimento e resfriamento.

- Durán-Suárez et al. (2000) estudaram a maneira pela qual cimentos, como cal ou cimento Portland, alteram a qualidade dos pigmentos utilizados em argamassa coloridas para uso na restauração de construções de pedra. As medidas colorimétricas indicam que ambos os aglomerantes diminuem a capacidade cromática da maioria dos pigmentos estudados.

- Fort et al. (2000) estudaram a eficácia de uma determinada técnica de limpeza, pela comparação dos parâmetros cromáticos obtidos em um edifício, antes e após o tratamento.

- Feliu et al. (2005) estudaram a variação de coloração da fachada de um prédio histórico na Espanha, afim de conhecer a história da construção (intervenções pelas quais foi submetida) e escolher materiais e cores que devem ser utilizadas em futuras intervenções.

- Franceschi et al. (2006) utilizaram o espectrofotômetro na caracterização de pátinas em estátuas de bronze expostas ao ar livre e na avaliação do efeito e durabilidade de determinados revestimentos aplicados em estátuas.

- Grossi et al. (2007a) estudaram o efeito da radiação do laser na coloração de granitos ornamentais utilizados como revestimento externo. As medidas dos parâmetros colorimétricos possibilitaram determinar danos a rocha devido à radiação do laser e as 
diversas respostas dos diferentes minerais. A análise dos dados também possibilitou sugerir as causas potenciais da mudança da cor e os limites de aplicabilidade da técnica.

- Grossi et al. (2007b) estudaram o impacto do ataque do dióxido de enxofre, deposição de partículas negras em ambientes urbanos e limpeza a laser, na mudança da cor de calcários ornamentais.

- Souza et al. (2008) estudaram os parâmetros colorimétricos de seis rochas ornamentais brasileiras (Granito Ouro Mel, Granito Cinza Corumbá, Granito Marrom Imperial, Granito Café Bahia, Granito Branco São Paulo e Granito Arabesco), determinando a quantidade mínima de medidas, para um espectrofotômetro com abertura de medição de $11 \mathrm{~mm}$, e afirmando que a técnica pode ser aplicada no controle de qualidade na construção civil.

- Prieto et al. (2010) determinaram a área mínima e o número de medidas requeridas para caracterizar a cor de uma rocha granítica, baseando-se em três parâmetros variáveis: tipo de rocha, tipo de superfície (rugosa, polida, serrada) e abertura do espectrofotômetro (diâmetros de 5, 8, 10 e 50mm).

\subsubsection{FUNDAMENTOS DA PROPAGAÇÃO DAS ONDAS ULTRASSÔNICAS}

A utilização de métodos vibracionais iniciou-se na década de 1930, sendo empregados inicialmente na determinação das propriedades físicas do concreto. Durante a II Guerra Mundial, na Inglaterra e no Canadá, os estudos impulsionaram-se, desenvolvendo-se aparelhos de ultrassom mais sofisticados (Naik et al., 2004), culminando na década de 1960, com o desenvolvimento do equipamento portátil, com visor digital, que mostra o tempo de trânsito da onda (Evangelista, 2002).

O método objetiva a determinação da velocidade de propagação das ondas elásticas em um dado meio. Para tanto, colocam-se em contato com a superfície dois transdutores, oemissor, que transforma em onda mecânica o pulso elétrico emitido pelo aparelho de ultrassom, e o receptor, que receberá a onda mecânica e a transformará em pulso elétrico novamente, medindo-se o tempo de trânsito da onda no meio estudado. Entre a superfície e os transdutores geralmente se utiliza um material acoplante (gel para ultrassom, graxa, resina, etc), a fim de se evitar a presença de ar, que atenua os valores de tempo obtidos.

Determinando a distância entre os locais da acoplagem dos transdutores (S), e tendose o tempo de trânsito da onda (t), obtém-se a velocidade pela seguinte expressão: 


$$
\mathrm{V}_{\mathrm{p}}=\mathrm{S} / \mathrm{t}
$$

Equação 8. Expressão para o cálculo da velocidade de propagação das ondas ultrassônicas.

A partir da interpretação do valor da velocidade é possível verificar se ocorrem variações na homogeneidade do material, o que pode indicar presença de fissuras, zonas com deterioração mineral, defeitos estruturais do material, etc. Cabe ressaltar que variações no tempo de trânsito podem estar associadas às modificações no meio de propagação da onda, relacionadas a variações na constituição mineralógica da rocha (presença de veios de quartzo, enclaves máficos), existência de estruturas (foliação, bandamento), diferenças na porosidade e ainda na saturação d'água.

Para a determinação da velocidade de propagação das ondas ultrassônicas existem três normas, compreendendo:

Testing of concrete by the ultrasonic pulse method (RILEM NDT 1, 1972);

Concreto endurecido - Determinação davelocidade de propagação de onda ultrasônica (ABNT NRB 8802, 1994);

Standard test method for laboratory determination ofpulse velocities and ultrasonic elastic constants of rock (ASTM 2845/00, 2000).

Atualmente o ultrassom é utilizado em várias áreas de pesquisa e nos mais diversos materiais, como madeira, aço, concreto, argamassa e rocha. Vários trabalhos exemplificam a aplicação da velocidade de propagação das ondas ultrassônicas, entre eles:

Chung e Law (1983) determinaram a velocidade de propagação das ondas ultrassônicas para diversos litotipos, entre eles: arenito $(\mathrm{Vp}=2,55-4,23 \mathrm{~km} / \mathrm{s})$, basalto $(\mathrm{Vp}=$ $5,27-6,02 \mathrm{~km} / \mathrm{s})$, calcário $(\mathrm{Vp}=3,91-5,78 \mathrm{~km} / \mathrm{s})$, dolomito $(\mathrm{Vp}=4,37-6,09 \mathrm{~km} / \mathrm{s})$, granito ( $\mathrm{Vp}$ $=4,00-5,79 \mathrm{~km} / \mathrm{s})$ e quartzito $(\mathrm{Vp}=5,57-5,72 \mathrm{~km} / \mathrm{s})$.

Rossi-Manaresi e Tucci (1983) determinaram a eficiência da consolidação realizada nas colunas, em arenito, do Palazzo Gaudenzi, construção do século XVI, a partir da comparação entre os valores de velocidade obtidos in situ, com os determinados pelas análises laboratoriais realizadas em corpos-de-prova do mesmo litotipo empregado no monumento.

Köhler (1988) determinou os valores da velocidade ultrassônica para alguns estágios de deterioração do mármore, sendo que para rocha sã está em torno de 5,0 km/s e rocha muito alterada em torno de $1,0 \mathrm{~km} / \mathrm{s}$. 
Topal e Doyuran (1995) avaliaram as propriedades físicas do tufo da Capadócia, Turquia, submetido a ciclos de saturação em água e secagem, congelamento e degelo e cristalização salina, em câmara de simulação intempérica.

Almesberger et al. (2000) estudaram o calcário Pietra D'Istria, rocha muito utilizada nos monumentos e construções de Veneza, utilizando transdutores de $55 \mathrm{kHz}$ e $120 \mathrm{kHz}$. Concluíram que os transdutores com frequência maior são mais sensíveis às heterogeneidades existentes nas amostras.

Papida et al. (2000) empregaram a velocidade de propagação das ondas ultrassônicas para avaliar calcários e dolomitos, provenientes respectivamente da Grécia e Reino Unido, após serem submetidos às simulações em câmaras intempéricas e ao ataque microbiológico.

Ziegler e Carmo (2003) aplicaram os procedimentos da norma brasileira ABNT NBR 8802/94, para inspeção e manutenção de estruturas em concreto armado, concluindo que a velocidade de propagação da onda ultrassônica auxilia na detecção de fissuras e falhas de adensamento no concreto.

Fitzner (2004) executou o mapeamento pontual de uma escultura existente na região de Nemrut Dag na Turquia, determinando os locais fissurados e com tendência a perda de partes.

Maia (2004) aplicou os procedimentos prescritos na norma norte-americana ASTM 2845/95 para avaliar as propriedades físicas de rochas ornamentais graníticas.

Silva (2005) aplicou o método na avaliação do estado de conservação das rochas do Teatro Municipal da cidade do Rio de Janeiro. Entre as conclusões, expressa a dificuldade de obtenção dos dados em rochas com superfície irregular e em locais com alto tráfego de veículos.

Marques et al. (2010) estudaram rochas metamórficas, determinando a variação da velocidade ultrassônica em função da orientação da foliação da rocha.

Gimenez (2012) avaliou o estado de conservação do Monumento as Bandeiras, localizado nas proximidades do Parque do Ibirapuera, São Paulo, pela comparação entre as velocidades de propagação das ondas ultrassônicas obtidas no monumento com as determinadas em laboratório, em corpos-de-prova do mesmo litotipo da estátua (Granito Cinza Mauá). Concluiu que a rocha do Monumento as Bandeiras apresenta-se sã.

Grossi (2013) avaliou o estado de conservação do Monumento a Ramos de Azevedo, localizado nas imediações do Instituto de Pesquisas Tecnológicas do Estado de São Paulo, Brasil, por vários métodos de análise não destrutivos, entre eles o espectrofotômetro e o ultrassom. Pela comparação entre as velocidades obtidas in situ com as determinadas nos corpos-de-prova da rocha sã (Granito Itaquera), concluiu que a rocha do monumento apresenta perda da sua homogeneidade. 


\subsubsection{DETERMINAÇÃO DO ESTADO DE DETERIORAÇÃO UTILIZANDO COLORIMETRIA E PROPAGAÇÃO DAS ONDAS ULTRASSÔNICAS}

Alguns túmulos foram avaliados com o uso da velocidade das ondas ultrassônicas e do espectrofotômetro, determinando-se a integridade, homogeneidade e as mudanças na cor da rocha. O estudo foi realizado em sete jazigos e no portão deentrada do cemitério (Tabela 5), cinco constituídos pelo Granito Itaquera e três constituídos por mármore (que compõe a estrutura dos jazigos mais antigos do cemitério). Os valores utilizados para o cálculo da velocidade de propagação da onda ultrassônica estão apresentados no Anexo 1.

Tabela 5. Objetos de estudo avaliados pelo uso da velocidade das ondas ultrassônicas e pelo uso do espectrofotômetro.

\begin{tabular}{c} 
OBJETOS DE ESTUDO \\
Granito Itaquera \\
\hline Portão de entrada do cemitério - Escritório Técnico Ramos de Azevedo \\
\hline Estátua Cristo - Escultor Elio de Giusto \\
\hline Estátua Interrogação - Escultor Francisco Leopoldo e Silva \\
\hline Estátua O Sepultamento - Escultor Victor Brecheret \\
Túmulo da Família Pereira Pinto \\
\hline Mármore \\
\hline Estátua Prece - Escultor Bruno Giorgi \\
Túmulo da Marquesa de Santos \\
Túmulo de Luisa Crema Marzorati
\end{tabular}

Para a realização do estudo com as ondas ultrassônicas, foram escolhidos jazigos que visualmente apresentavam um estado de conservação homogêneo, permitindo que a média das velocidades obtidas represente o estado de conservação de toda a estrutura analisada. As medidas foram obtidas nos dias 03 de abril e 01 de agosto de 2012, sob condições semelhantes: dias ensolarados; ausência de chuva por mais de uma semana; horário de análise das $8 \mathrm{~h}$ às $16 \mathrm{~h}$.

As variações das cores das rochas foram determinadas pela colorimetria, avaliando as modificações dos parâmetros colorimétricos de um local em função da passagem do tempo, ou pela comparação de distintos locais numa mesma ou diferente estrutura. Para realização das análises foi empregado o método proposto por Prieto et al. (2010). O estudo foca a determinação da quantidade mínima de análises necessárias para a caracterização representativa da cor, em função do diâmetro da abertura do equipamento utilizado para as medições, tipo de polimento da superfície, e para diferentes tipos de rochas graníticas. Os 
parâmetros colorimétricos obtidos foram analisados inicialmente por gráficos de média acumulada e posteriormente pela análise de variância multivariada (MANOVA). Modificando as variáveis e aplicando as análises estatísticas, foram determinadasquantidades mínimas de analises que deveriam ser empregadas para a caracterização de uma área fixa de $36 \mathrm{~cm}^{2}$.

Por se tratar de um método laboratorial, algumas condições de análise precisaram ser modificadas para atender a realidade do estudo proposto, que é caracterizar modificações nas cores das rochas de maneira preliminar, avaliando a aplicabilidade do espectrofotômetro para essa finalidade. Optou-se então pelo abandono da área mínima, estudando o monumento como um todo, entretanto mantendo as 14 medidas indicadas para caracterizações com equipamentos que possuemdiâmetro de abertura de $8 \mathrm{~mm}$.

O abandono da área mínima foi proposto em função das características mineralógicas e texturais das rochas estudadas. O mármore é uma rocha com mineralogia e textura homogêneas, não apresentando variação significativa da sua cor.OGranito Itaquera, um biotita granito cinza, com estrutura maciça às vezes levemente orientada, possui textura fanerítica fina, eproporciona uma coloração bastante homogênea.

Para comprovar que as 14 medidas seriam suficientes para a caracterização colorimétrica representativa do Granito Itaquera, foi empregado o método da estabilização das médias acumulativas, proposto por Prieto et al. (2010). O estudo foi realizado no Portão de entrada do Cemitério da Consolação, construído pelo Escritório Técnico Ramos de Azevedo (Figuras 63 e 64), pois apresenta condições ideais de estudo, tais como: grande variação da cor da rocha e dimensões superior a dos outros objetos de estudo. As análises foram obtidas em quatro locais distintos da estrutura (Figuras 65 a 68), realizando 14 medidas em cada um dos locais. Não foi realizado tal estudo para o mármore, por se tratar de uma rocha com cor muito mais homogênea. 


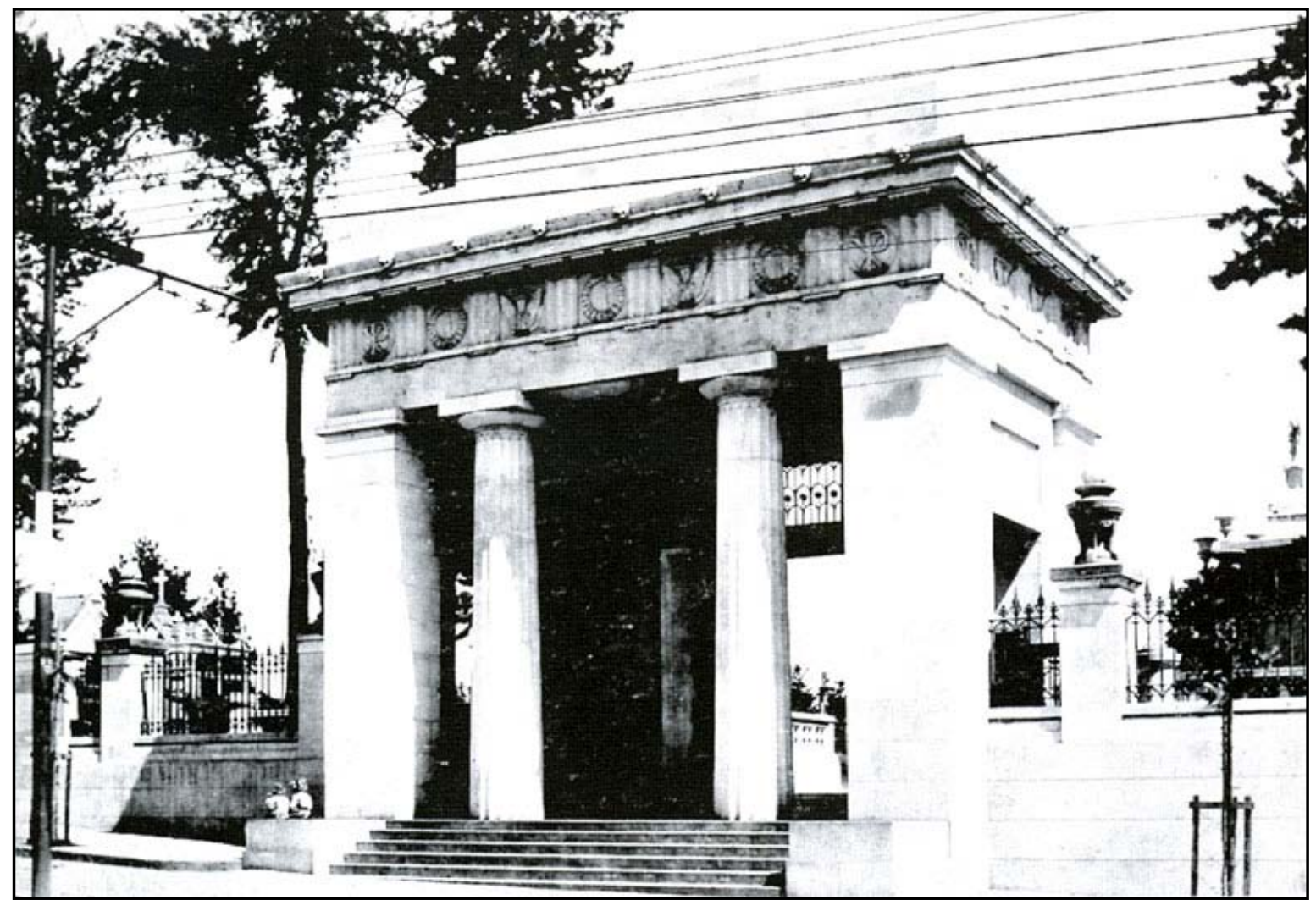

Figura 63. Portal de entrada do cemitério da Consolação no inicio do século XX.

Fonte: Carvalho (2000).

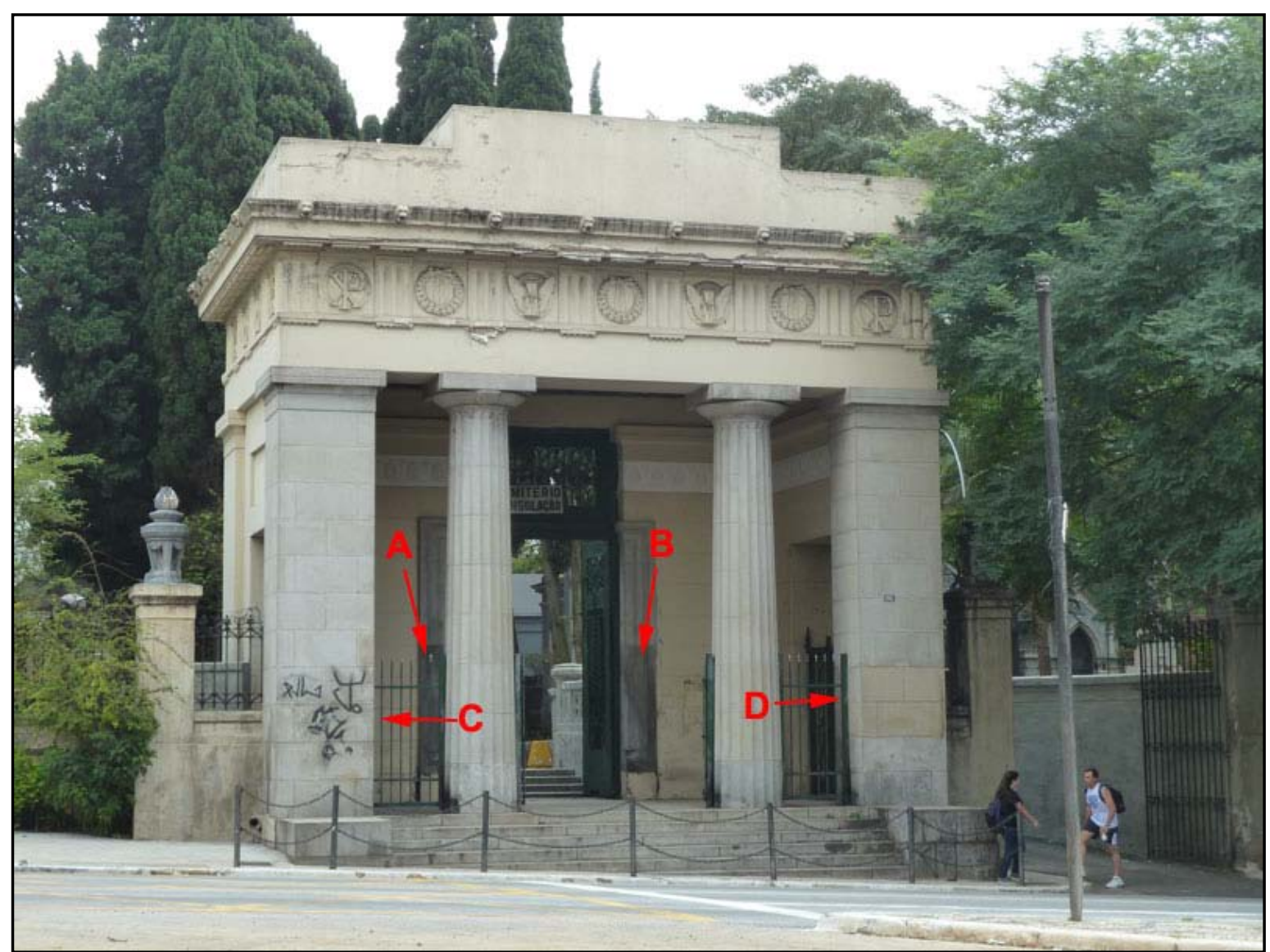

Figura 64. Portal de entrada do cemitério da Consolação em 2012. As letras A,B,C e D indicam os locais analisados. 


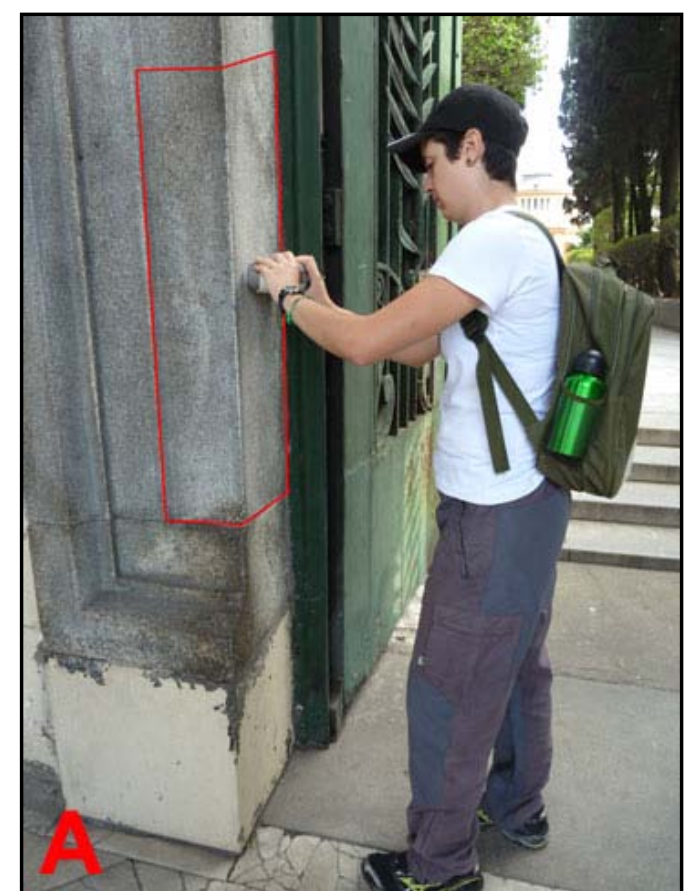

Figura 65. Detalhe do local analisado A.

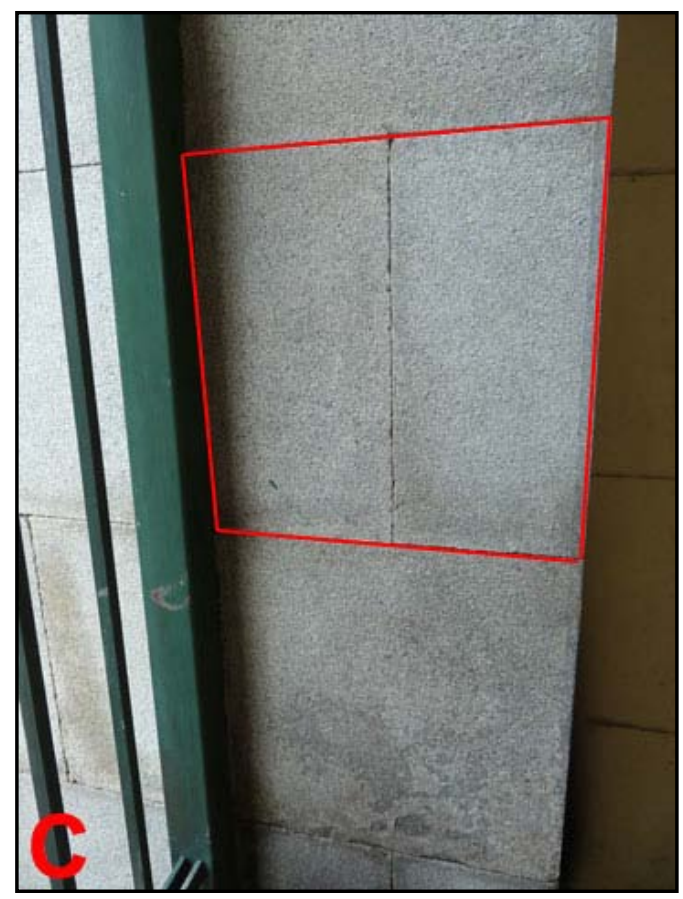

Figura 67. Detalhe do local analisado $\mathrm{C}$.

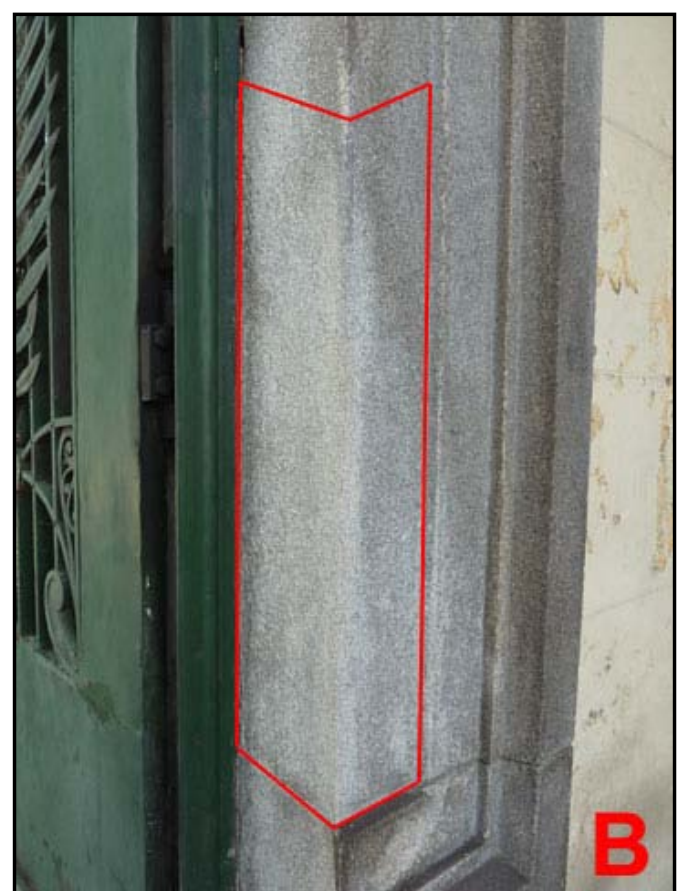

Figura 66. Detalhe do local analisado B.

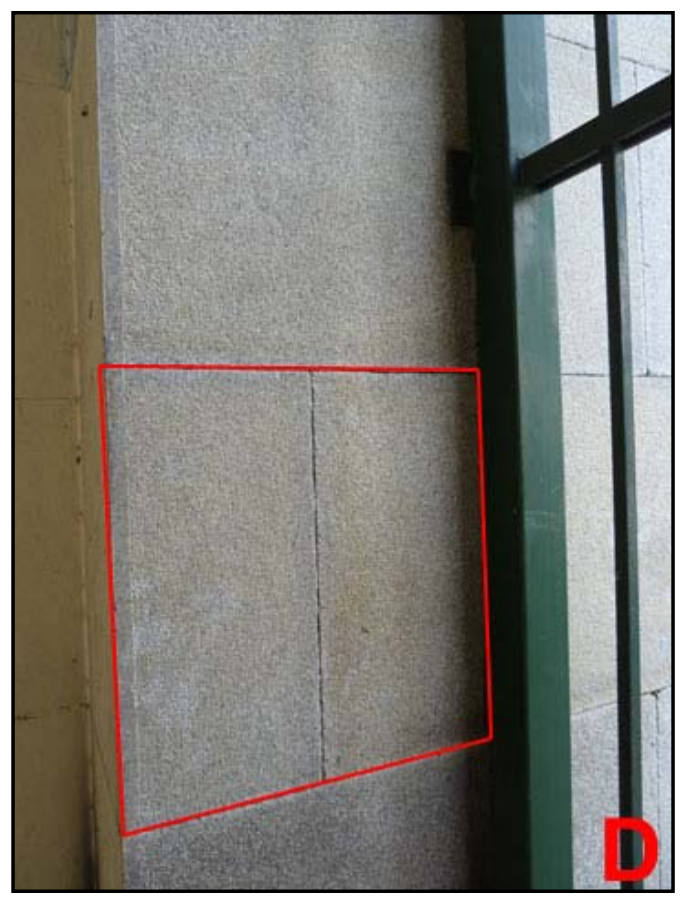

Figura 68. Detalhe do local analisado D. 
As médias cumuladas para os parâmetros $L^{*}$, $a^{*}$ e $b^{*}$, em função do número de medidas somadas, são apresentados nas Figuras 69 a 71 . Para o parâmetro $L^{*}$, a representatividade da sua média pode ser obtida com 13 medidas. Já para os parâmetros $a^{*}$ e b*, cerca de quatro medidas são suficientes para a estabilização do valor da média.

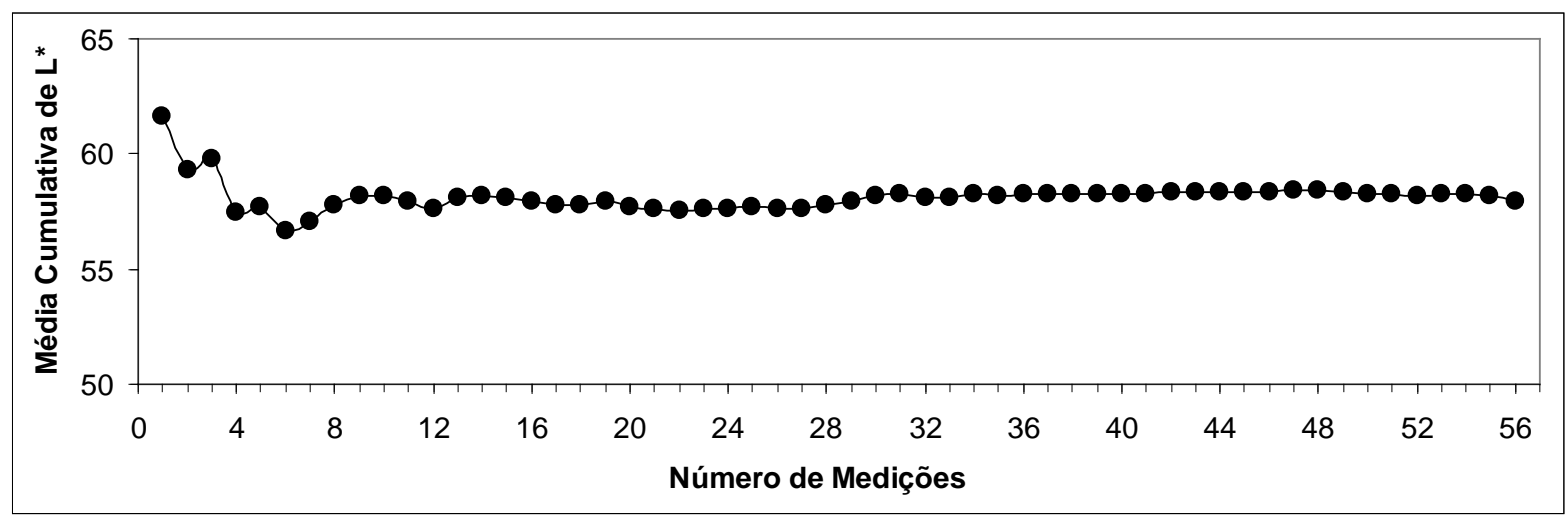

Figura 69. Gráfico utilizado na determinação do número mínimo de medidas necessárias para obter o valor representativo da média do parâmetro colorimétrico $L^{*}$.

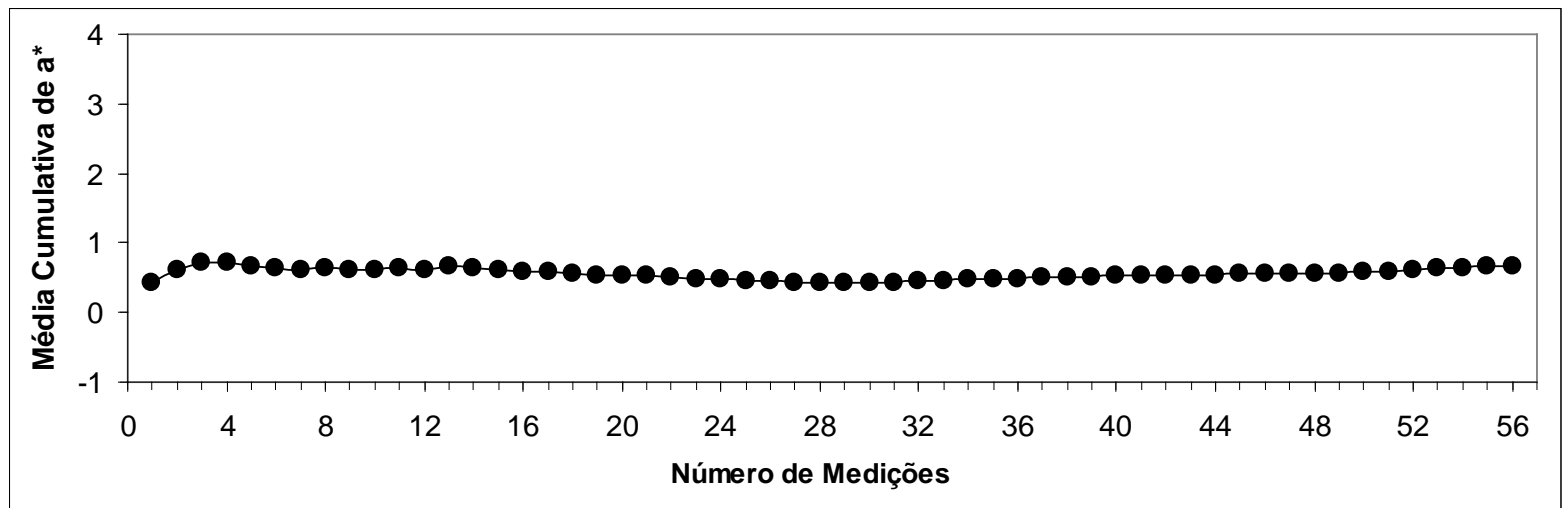

Figura 70. Gráfico utilizado na determinação do número mínimo de medidas necessárias para obter o valor representativo da média do parâmetro colorimétrico $\mathrm{a}^{*}$.

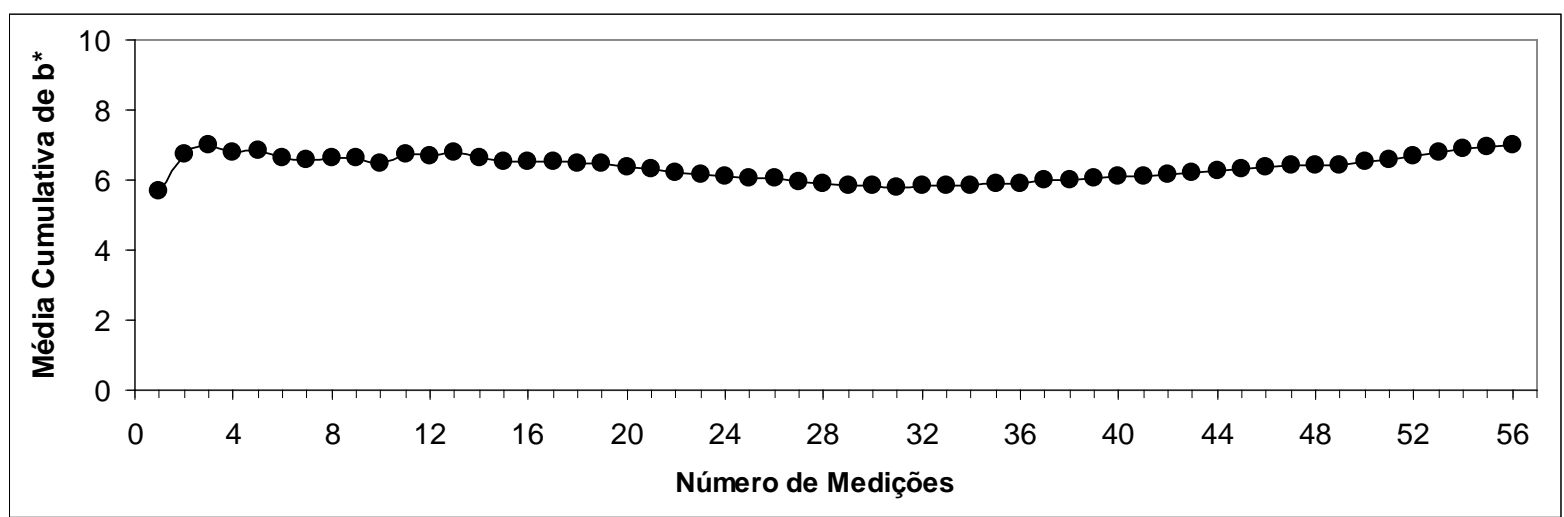

Figura 71. Gráfico utilizado na determinação do número mínimo de medidas necessárias para obter o valor representativo da média do parâmetro colorimétrico $b^{*}$. 
O Portão de entrada do Cemitério da Consolação foi estudado ao longo de três anos para se avaliar possíveis modificações na cor da rocha. Nesse período foram realizados quatro dias de medições, sempre obtendo dados nos quatro locais definidos anteriormente. Os valores da estatística descritiva aplicada aos parâmetros colorimétricos $L^{*}, a^{*}$ e $b^{\star}$, em função da data e local estudado, são apresentados na Tabela 6.

Tabela 6. Os valores da estatística descritiva aplicada aos parâmetros colorimétricos $L^{*}, a^{*}$ e $b^{\star}$, em função da data e local estudado.

\begin{tabular}{|c|c|c|c|c|c|c|}
\hline Local de Estudo / Data & Estatística & $L^{*}$ & $a^{*}$ & $\mathbf{b}^{*}$ & $C^{*}$ & $\mathbf{H}^{\circ}$ \\
\hline \multirow{2}{*}{ Local A - 30/07/2010(1A) } & Média & 54,91 & 0,54 & 5,22 & 5,25 & 84,59 \\
\hline & Desvio Padrão & 3,76 & 0,32 & 1,24 & 1,26 & 2,43 \\
\hline \multirow{2}{*}{ Local B - 30/07/2010(1B) } & Média & 56,62 & 0,29 & 4,88 & 4,89 & 86,79 \\
\hline & Desvio Padrão & 2,94 & 0,20 & 1,00 & 1,00 & 1,85 \\
\hline \multirow{2}{*}{ Local C - 30/07/2010(1C) } & Média & 60,94 & 0,74 & 5,23 & 5,29 & 82,15 \\
\hline & Desvio Padrão & 4,08 & 0,34 & 1,09 & 1,12 & 2,04 \\
\hline \multirow{2}{*}{ Local D - 30/07/2010(1D) } & Média & 61,02 & 1,13 & 9,80 & 9,87 & 83,46 \\
\hline & Desvio Padrão & 2,96 & 0,31 & 1,61 & 1,63 & 1,15 \\
\hline \multirow{2}{*}{ Local A - 05/04/2011(2A) } & Média & 59,79 & 0,76 & 6,58 & 6,62 & 83,41 \\
\hline & Desvio Padrão & 2,80 & 0,14 & 1,02 & 1,03 & 0,73 \\
\hline \multirow{2}{*}{ Local B - 05/04/2011(2B) } & Média & 58,57 & 0,26 & 4,97 & 4,98 & 87,28 \\
\hline & Desvio Padrão & 5,39 & 0,20 & 1,23 & 1,24 & 1,64 \\
\hline \multirow{2}{*}{ Local C - 05/04/2011(2C) } & Média & 62,41 & 0,76 & 5,81 & 5,87 & 82,63 \\
\hline & Desvio Padrão & 4,11 & 0,24 & 1,32 & 1,33 & 1,58 \\
\hline \multirow{2}{*}{ Local D - 05/04/2011(2D) } & Média & 62,07 & 1,37 & 11,37 & 11,45 & 83,23 \\
\hline & Desvio Padrão & 2,63 & 0,33 & 1,42 & 1,44 & 0,94 \\
\hline \multirow{2}{*}{ Local A - 02/04/2012(3A) } & Média & 58,15 & 0,65 & 6,64 & 6,67 & 84,53 \\
\hline & Desvio Padrão & 4,04 & 0,26 & 1,24 & 1,25 & 1,37 \\
\hline \multirow{2}{*}{ Local B - 02/04/2012(3B) } & Média & 57,45 & 0,21 & 5,15 & 5,15 & 87,87 \\
\hline & Desvio Padrão & 2,40 & 0,19 & 0,96 & 0,96 & 1,99 \\
\hline \multirow{2}{*}{ Local C - 02/04/2012(3C) } & Média & 59,33 & 0,75 & 6,61 & 6,65 & 83,61 \\
\hline & Desvio Padrão & 2,82 & 0,25 & 1,26 & 1,27 & 1,38 \\
\hline \multirow{2}{*}{ Local D - 02/04/2012(3D) } & Média & 56,97 & 1,03 & 9,50 & 9,56 & 83,98 \\
\hline & Desvio Padrão & 3,75 & 0,40 & 1,90 & 1,93 & 1,40 \\
\hline \multirow{2}{*}{ Local A - 14/08/2012(4A) } & Média & 60,34 & 0,64 & 5,50 & 5,54 & 84,25 \\
\hline & Desvio Padrão & 4,30 & 0,42 & 1,53 & 1,56 & 3,50 \\
\hline \multirow{2}{*}{ Local B - 14/08/2012(4B) } & Média & 60,47 & 0,32 & 4,76 & 4,78 & 86,42 \\
\hline & Desvio Padrão & 4,60 & 0,26 & 1,01 & 1,02 & 2,97 \\
\hline \multirow{2}{*}{ Local C - 14/08/2012(4C) } & Média & 58,22 & 0,88 & 6,05 & 6,12 & 81,91 \\
\hline & Desvio Padrão & 2,90 & 0,36 & 1,38 & 1,41 & 2,12 \\
\hline \multirow{2}{*}{ Local D - 14/08/2012(4D) } & Média & 61,54 & 1,04 & 9,39 & 9,45 & 83,81 \\
\hline & Desvio Padrão & 3,02 & 0,33 & 1,75 & 1,77 & 1,12 \\
\hline
\end{tabular}


Os valores das diferenças dos parâmetros colorimétricos $L^{*}, a^{*}, b^{*}$ e $C^{\star}$ e diferença total de cor $\Delta E$ ), para comparações entre os locais de estudo $A, B, C$ e $D$, para análises realizadas em uma mesma data, são apresentados na Tabela 7.

Tabela 7. Diferenças dos parâmetros colorimétricos $L^{*}, a^{*}, b^{*} e C^{*}$ e diferença total de cor $(\Delta E)$, para comparações entre os locais de estudo $A, B, C$ e $D$ para análises realizadas em uma mesma data.

\begin{tabular}{|c|c|c|c|c|c|}
\hline $\begin{array}{c}\text { Locais e Datas } \\
\text { Comparadas }\end{array}$ & $\boldsymbol{\Delta} \mathbf{L}^{*}$ & $\mathbf{\Delta} \mathbf{a}^{*}$ & $\boldsymbol{\Delta} \mathbf{b}^{*}$ & $\boldsymbol{\Delta} \mathbf{C}^{*}$ & $\boldsymbol{\Delta} \mathbf{E}$ \\
\hline 1B-1A & 1,71 & $-0,25$ & $-0,34$ & $-0,36$ & 1,76 \\
\hline 1C-1A & 6,03 & 0,20 & 0,01 & 0,04 & 6,03 \\
\hline 1D-1A & 6,11 & 0,59 & 4,58 & 4,62 & 7,66 \\
\hline 1C-1B & 4,32 & 0,45 & 0,35 & 0,40 & 4,36 \\
\hline 1D-1B & 4,40 & 0,84 & 4,92 & 4,98 & 6,65 \\
\hline 1D-1C & 0,08 & 0,39 & 4,57 & 4,58 & 4,59 \\
\hline 2B-2A & $-1,22$ & $-0,50$ & $-1,61$ & $-1,64$ & 2,08 \\
\hline 2C-2A & 2,62 & $-0,00$ & $-0,77$ & $-0,75$ & 2,73 \\
\hline 2D-2A & 2,28 & 0,61 & 4,79 & 4,83 & 5,34 \\
\hline 2C-2B & 3,84 & 0,50 & 0,84 & 0,89 & 3,96 \\
\hline 2D-2B & 3,50 & 1,11 & 6,40 & 6,47 & 7,38 \\
\hline 2D-2C & $-0,34$ & 0,61 & 5,56 & 5,58 & 5,60 \\
\hline 3B-3A & $-0,70$ & $-0,44$ & $-1,49$ & $-1,52$ & 1,70 \\
\hline 3C-3A & 1,18 & 0,10 & $-0,03$ & $-0,02$ & 1,18 \\
\hline 3D-3A & $-1,18$ & 0,38 & 2,86 & 2,89 & 3,12 \\
\hline 3C-3B & 1,88 & 0,54 & 1,46 & 1,50 & 2,44 \\
\hline 3D-3B & $-0,48$ & 0,82 & 4,35 & 4,41 & 4,45 \\
\hline 3D-3C & $-2,36$ & 0,28 & 2,89 & 2,91 & 3,74 \\
\hline 4B-4A & 0,13 & $-0,32$ & $-0,74$ & $-0,76$ & 0,82 \\
\hline 4C-4A & $-2,12$ & 0,24 & 0,55 & 0,58 & 2,20 \\
\hline 4D-4A & 1,20 & 0,40 & 3,89 & 3,91 & 4,09 \\
\hline 4C-4B & $-2,25$ & 0,56 & 1,29 & 1,34 & 2,65 \\
\hline 4D-4B & 1,07 & 0,72 & 4,63 & 4,67 & 4,81 \\
\hline 4D-4C & 3,32 & 0,16 & 3,34 & 3,33 & 4,71 \\
\hline
\end{tabular}


Os valores das diferenças dos parâmetros colorimétricos $L^{*}, a^{*}, b^{*}$ e $C^{*}$ e diferença total de $\operatorname{co\Delta } \mathrm{E}$ ), para comparẹões das análises realizadas em datas diferentes, para uma mesmo local de estudo ( $, B, C$ ou D), são apresentados na Tabela 8.

Tabela 8. Diferenças dos parâmetros colorimétricos $L^{*}, a^{\star}, b^{*}$ e $C^{*}$ e diferença total de cor $(\Delta \mathrm{E})$, para comparações das análises realizadas em datas diferentes, para uma mesmo local de estudo (A, B, C ou D).

\begin{tabular}{|c|c|c|c|c|c|}
\hline $\begin{array}{c}\text { Locais de } \\
\text { Comparação }\end{array}$ & $\boldsymbol{\Delta} \mathbf{L}^{*}$ & $\boldsymbol{\Delta} \mathbf{a}^{*}$ & $\boldsymbol{\Delta} \mathbf{b}^{*}$ & $\boldsymbol{\Delta} \mathbf{C}^{*}$ & $\boldsymbol{\Delta} \mathbf{E}$ \\
\hline 2A-1A & 4,88 & 0,22 & 1,36 & 1,37 & 5,07 \\
\hline 3A-1A & 3,24 & 0,11 & 1,42 & 1,42 & 3,54 \\
\hline 4A-1A & 5,43 & 0,10 & 0,28 & 0,29 & 5,44 \\
\hline 3A-2A & $-1,64$ & $-0,11$ & 0,06 & 0,05 & 1,64 \\
\hline 4A-2A & 0,55 & $-0,12$ & $-1,08$ & $-1,08$ & 1,22 \\
\hline 4A-3A & 2,19 & $-0,01$ & $-1,14$ & $-1,13$ & 2,47 \\
\hline 2B-1B & 1,95 & $-0,03$ & 0,09 & 0,09 & 1,95 \\
\hline 3B-1B & 0,83 & $-0,08$ & 0,27 & 0,26 & 0,88 \\
\hline 4B-1B & 3,85 & 0,03 & $-0,12$ & $-0,11$ & 3,85 \\
\hline 3B-2B & $-1,12$ & $-0,05$ & 0,18 & 0,17 & 1,14 \\
\hline 4B-2B & 1,90 & 0,06 & $-0,21$ & $-0,20$ & 1,91 \\
\hline 4B-3B & 3,02 & 0,11 & $-0,39$ & $-0,37$ & 3,05 \\
\hline 2C-1C & 1,47 & 0,02 & 0,58 & 0,58 & 1,58 \\
\hline 3C-1C & $-1,61$ & 0,01 & 1,38 & 1,36 & 2,12 \\
\hline 4C-1C & $-2,72$ & 0,14 & 0,82 & 0,83 & 2,84 \\
\hline 3C-2C & $-3,08$ & $-0,01$ & 0,80 & 0,78 & 3,18 \\
\hline 4C-2C & $-4,19$ & 0,12 & 0,24 & 0,25 & 4,20 \\
\hline 4C-3C & $-1,11$ & 0,13 & $-0,56$ & $-0,53$ & 1,25 \\
\hline 2D-1D & 1,05 & 0,24 & 1,57 & 1,58 & 1,90 \\
\hline 3D-1D & $-4,05$ & $-0,10$ & $-0,30$ & $-0,31$ & 4,06 \\
\hline 4D-1D & 0,52 & $-0,09$ & $-0,41$ & $-0,42$ & 0,67 \\
\hline 3D-2D & $-5,10$ & $-0,34$ & $-1,87$ & $-1,89$ & 5,44 \\
\hline 4D-2D & $-0,53$ & $-0,33$ & $-1,98$ & $-2,00$ & 2,08 \\
\hline 4D-3D & 4,57 & 0,01 & $-0,11$ & $-0,11$ & 4,57 \\
\hline
\end{tabular}


Os valores dos parâmetros colorimétricos $L^{*}, a^{*}, b^{*}$ e $C^{*}$ foram interpolados em diagramas de dispersão cartesianos $\left(C^{*} x L^{*}\right)$ e polares $\left(a^{*} x b^{*}\right)$ para visualização das variações desses índices em função dos diferentes locais e datas estudados. As Figuras 72 a 74 mostram as análises realizadas no dia 30 de julho de 2010.

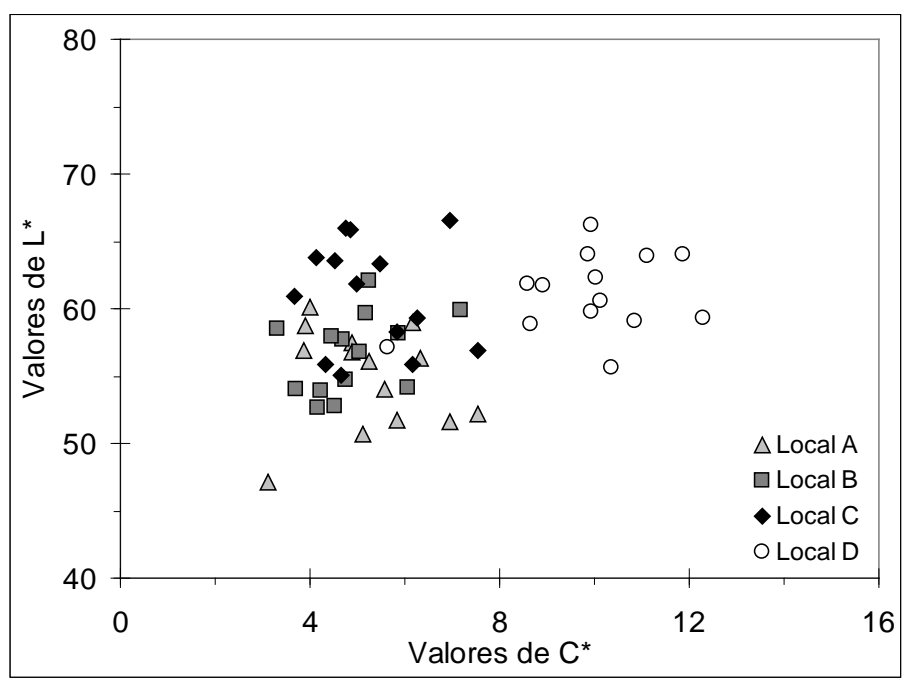

Figura 72. Diagrama de dispersão cartesiano para as variáveis $C^{*}$ e L* obtidas no dia 30/07/2010.

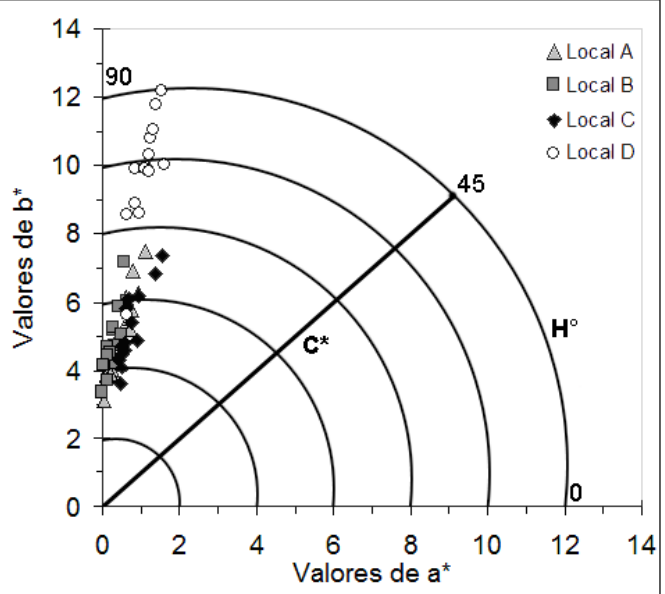

Figura 73. Diagrama de dispersão polar para as variáveis $a^{*}$ e $b^{\star}$ obtidas no dia 30/07/2010.

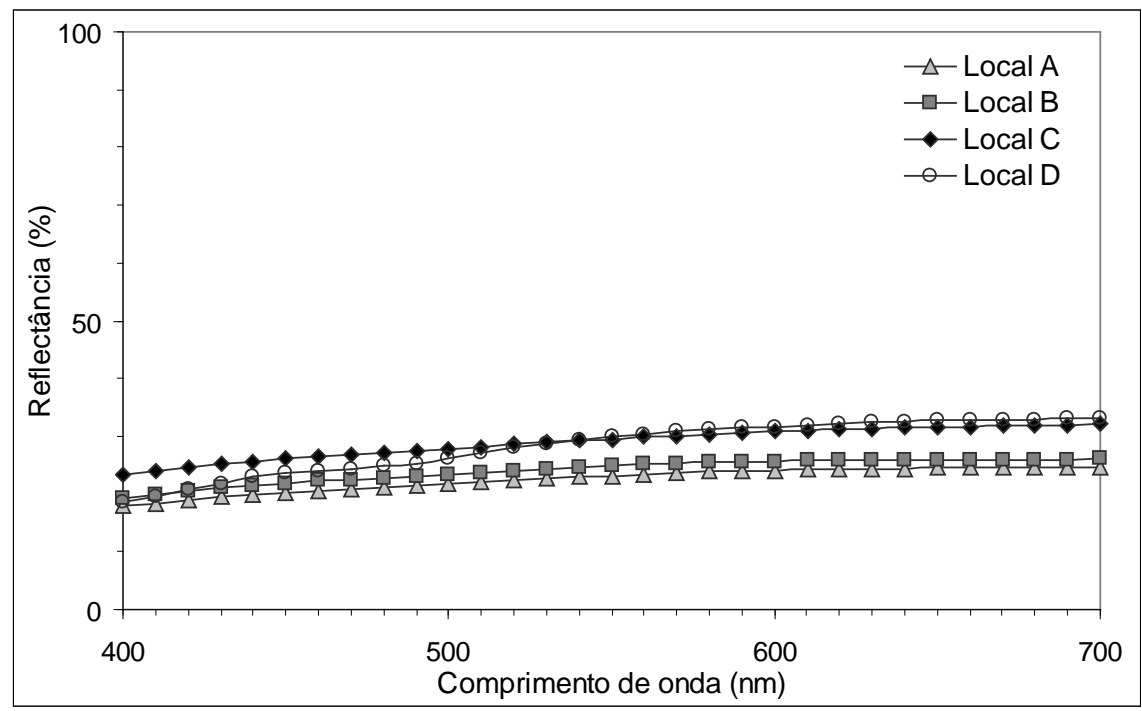

Figura 74. Gráfico de reflectância espectral para os dados obtidos no dia 30/07/2010.

Na Figura 72, o Local A apresenta os menores valores de L* (média de 54,91), sendo o mais escuro, enquanto o Local D apresenta os valores de $L^{*}$ mais elevados (média de 61,02), constituindo o mais claro. Os valores do Local B (média de 56,62) apresentam correlação com os valores do Local A, enquanto os valores do Local C (média de 60,94) apresentam correlação com os valores do Local D. Os valores de $C$ * para os locais $A$ (média de 5,25), B (média de 4,89) e C (média de 5,29) apresentam grande correlação, enquanto o 
Local D apresenta valores superiores (média de 9,87). Esses valores altos de C* para o Local D é explicado pela Figura 73, que mostra que esse local é o que apresenta maiores valores de $b^{*}$ (Neste caso, os valores de $b^{*}$ apresentam uma representatividade maior que os valores de $a^{\star}$ para o cálculo da saturação), constituindo o local mais amarelado, como já determinado visualmente. Ainda segundo a Figura 73, todos os locais apresentam baixos valores de $a^{\star}$, o que indica que a cor da rocha possui baixa saturação, tendendo aos tons de cinza, e altos valores de $\mathrm{H}^{\circ}$ (superiores a $80^{\circ}$ ), parâmetro que evidencia que todos os locais tendem ao amarelamento. No gráfico de reflectância espectral (Figura 74), nota-se que os locais A, B e C apresentam uma reflectância homogênea em todos os comprimentos de onda, enquanto o Local D apresenta um aumento da quantidade de luz refletida a partir dos $500 \mathrm{~nm}$ (comprimento de onda que corresponde ao verde), atingindo o valor máximoao redor dos 650nm (comprimento de onda que corresponde ao laranja), indicando também o amarelamento desse local se comparado aos outros.

As Figuras 75 a 77 mostram as análises realizadas no dia 05 de abril de 2011.

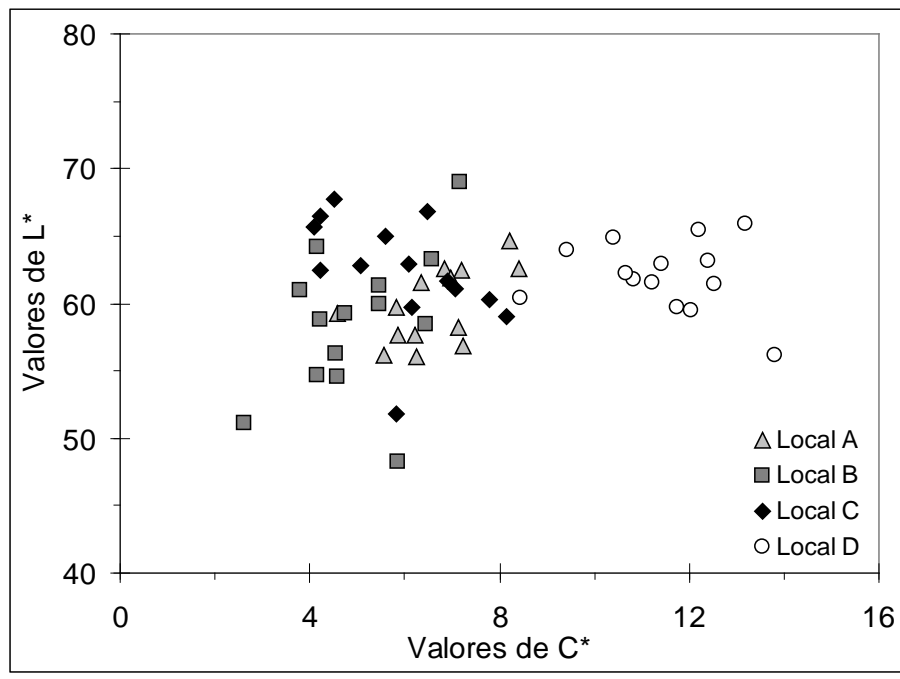

Figura 75. Diagrama de dispersão cartesiano para as variáveis $C^{*}$ e L* obtidas no dia 05/04/2011.

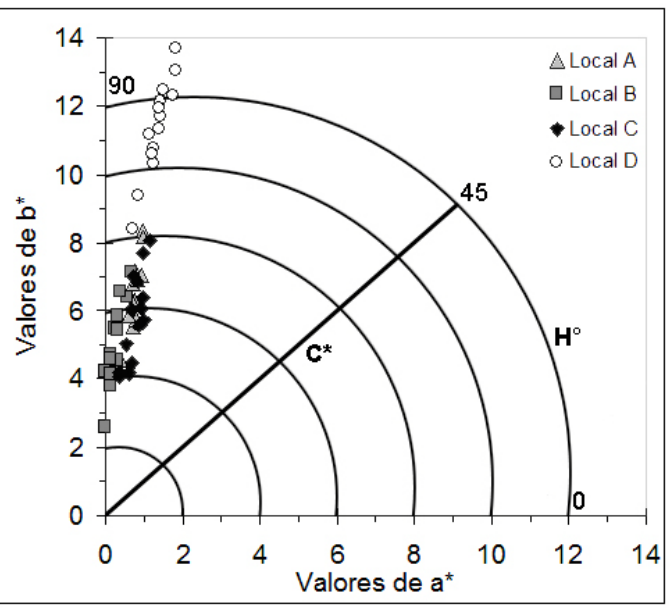

Figura 76. Diagrama de dispersão polar para as variáveis $a^{*}$ e $b^{*}$ obtidas no dia 05/04/2011. 


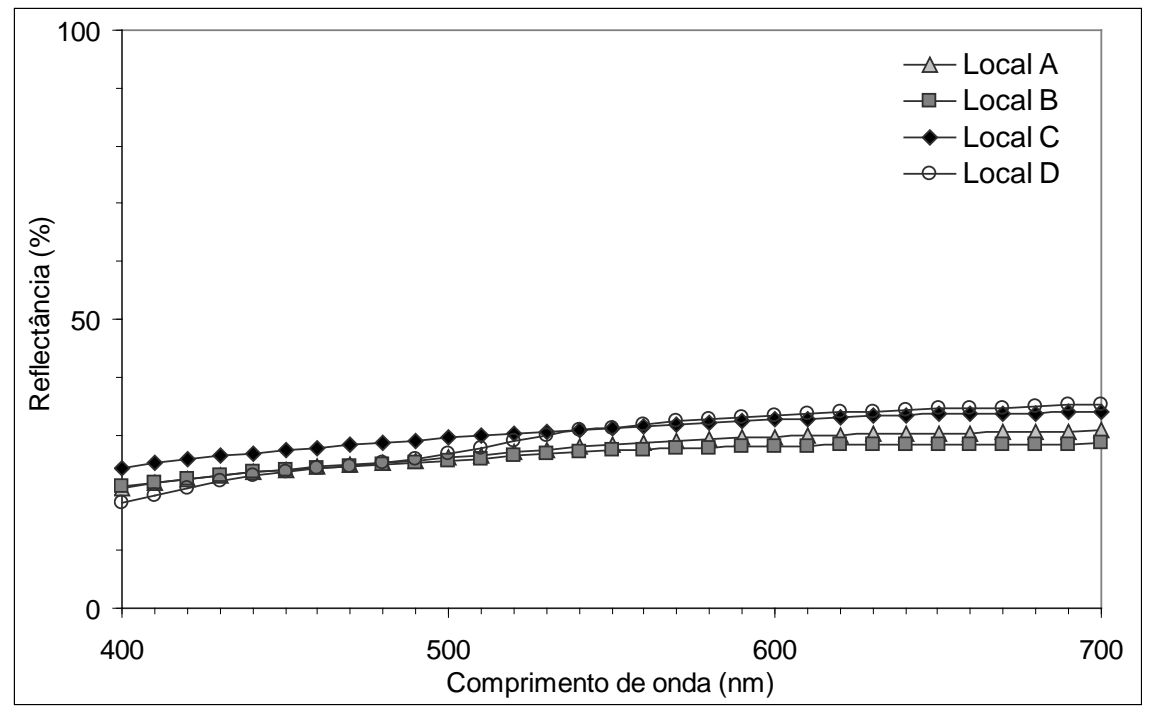

Figura 77. Gráfico de reflectância espectral para os dados obtidos no dia 05/04/2011.

Na Figura 75, o Local B apresenta os menores valores de L* (média de 58,57), sendo o mais escuro, enquanto o Local $C$ apresenta os valores de $L^{*}$ mais elevados (média de 62,41 ), constituindo o mais claro. Os valores de $L^{*}$ para os locais $A$ (média de 59,79 ) e $B$, e para D (média de 62,07) e C, continuam a apresentar correlação. Comparando-se esses valores de $L^{*}$ com os obtidos em 30/07/2010, nota-se o aumento da luminosidade em todos os locais. Os valores de C* não se apresentam mais tão correlacionados (Local A, média de 6,62; Local B, média de 4,98; Local C, média de 5,87; Local D, média de 11,45), com o Local D continuando a apresentar os maiores valores. A Figura 76 mostra um pequeno aumentodos parâmetros $a^{*}, b^{*}$ e consequentemente $C^{*}$, evidenciando o amarelamento de todos os locais, com o Local D permanecendo o mais amarelado (Média de b* igual a 11,37 ). Os valores de $H^{\circ}$ permanecem altos (superiores a $80^{\circ}$ ), com pouca variação aos obtidos na análise realizada anteriormente. No gráfico de reflectância espectral (Figura 77) nota-se que os locais A, B e C continuam a apresentar uma reflectância homogênea em todos os comprimentos de onda, enquanto o Local D apresenta um aumento da quantidade de luz refletida mais significativo do que anteriormente, agora a partir dos 480nm (comprimento de onda que corresponde ao azul), atingindo o valor máximo ao redor dos 690nm (comprimento de onda que corresponde ao vermelho), indicando também certoavermelhamentodesse local se comparado aos outros. 
As Figuras 78 a 80 mostram as análises realizadas no dia 02 de abril de 2012.
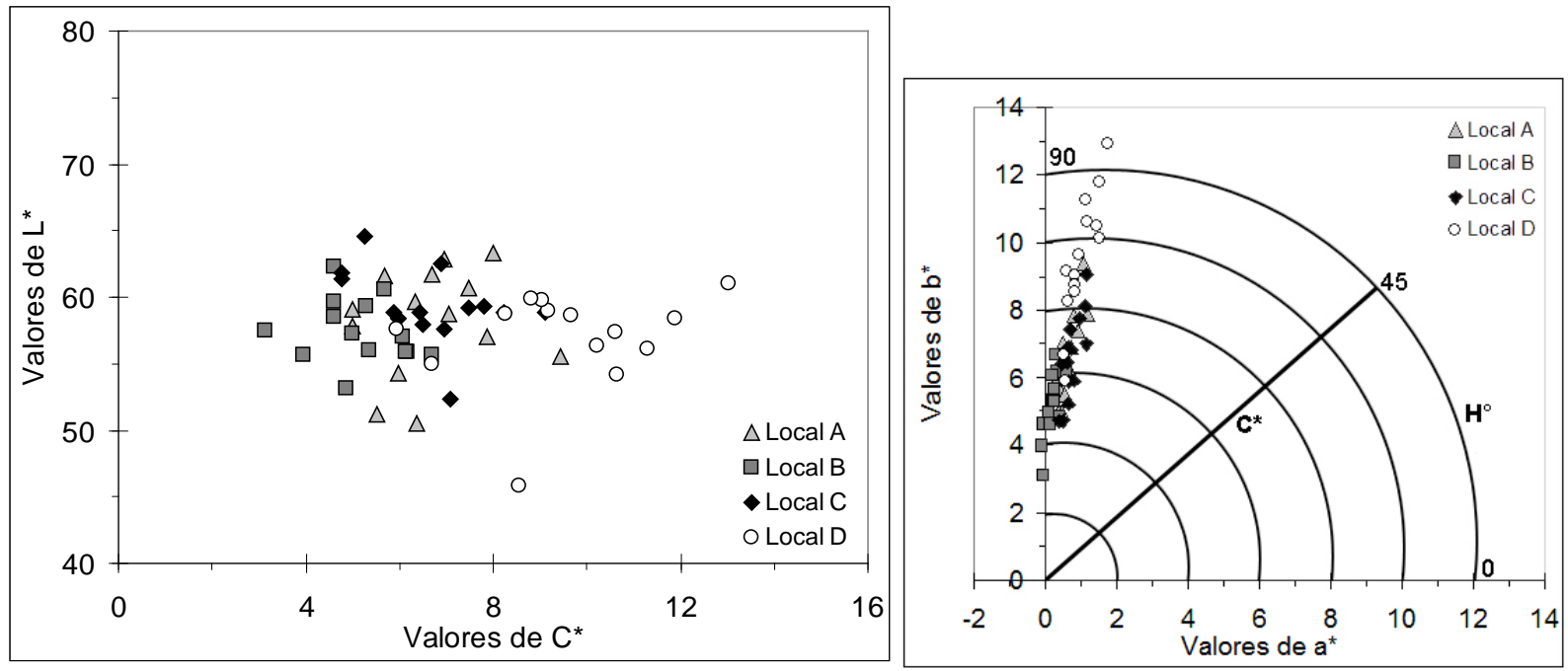

Figura 78. Diagrama de dispersão cartesiano para as

Figura 79. Diagrama de dispersão polar variáveis $C^{*}$ e $L^{*}$ obtidas no dia 02/04/2012. para as variáveis $a^{\star}$ e $b^{\star}$ obtidas no dia 02/04/2012.

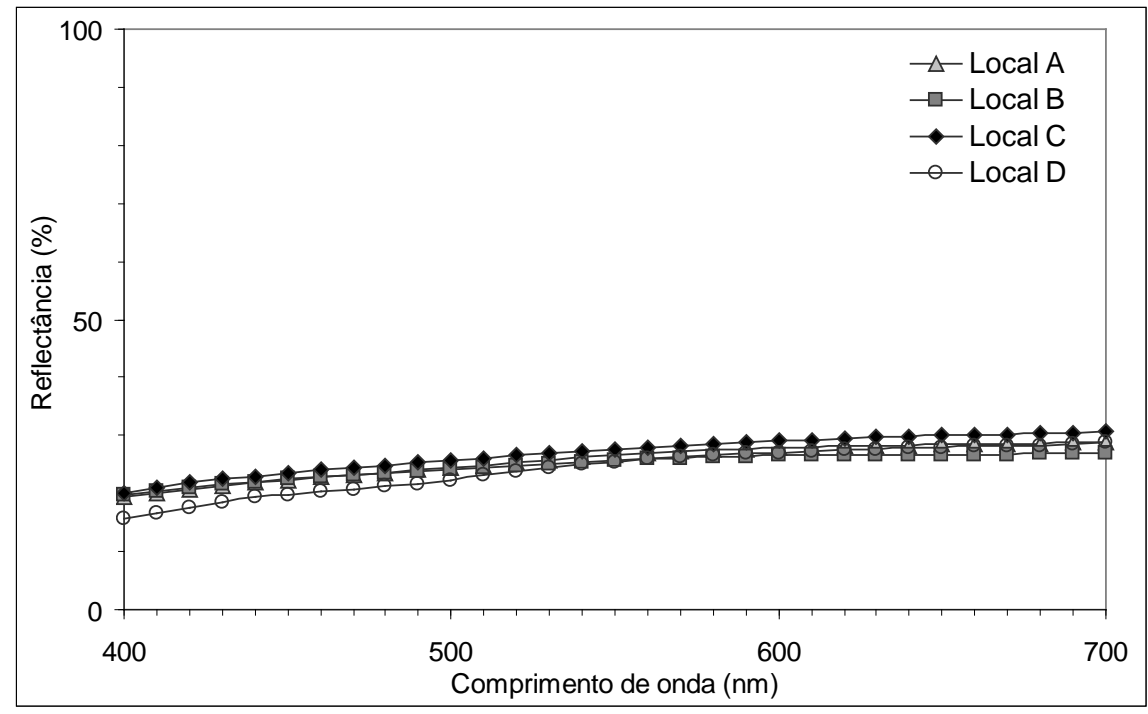

Figura 80. Gráfico de reflectância espectral para os dados obtidos no dia 02/04/2012.

Na Figura 78, nota-se a diminuição da luminosidade em todos os locais analisados, se comparados esses dados com os obtidos em 05/04/2011, com o Local D apresentando os menores valores de $L^{*}$ (média de 56,97) e o Local C os mais elevados (média de 59,33). A correlação dos valores de $L^{*}$ para os Locais $A$ - B e C - D não é mais notada, entretanto pode-se associar esse escurecimento ao aumento da quantidade fuligem na superfície da rocha. Os valores de $C *$ se correlacionam novamente (Local A, média de 6,67; Local $B$, média de 5,15; Local C, média de 6,65; Local D, média de 9,56), notando-se o aumento da saturação da cor para todos os locais, salvo o Local D que apesar de continuar a possuir os maiores valores, apresentou diminuição na sua saturação se comparada 
aobtidaanteriormente $\left(\Delta \mathrm{C}^{*}{ }_{3 \mathrm{D}-2 \mathrm{D}}=-1,89\right)$, em função da diminuição das cromacidades $\mathrm{a}^{\star}$ e $\mathrm{b}^{*}$ $\left(\Delta \mathrm{a}^{*}{ }_{3 \mathrm{D}-2 \mathrm{D}}=-0,34 ; \Delta \mathrm{b}^{*}{ }_{3 \mathrm{D}-2 \mathrm{D}}=-1,87\right)$.

A Figura 79 mostra uma pequenadiminuição nos valores do parâmetro $a^{\star}$, o que é evidenciado pelos valores dos deltas $\left(\Delta \mathrm{a}^{*}{ }_{3 \mathrm{~A}-2 \mathrm{~A}}=-0,11 ; \Delta \mathrm{a}^{*}{ }_{3 \mathrm{~B}-2 \mathrm{~B}}=-0,05 ; \Delta \mathrm{a}^{*}{ }_{3 \mathrm{C}-2 \mathrm{C}}=-0,01 ; \Delta \mathrm{a}^{*}{ }_{3 \mathrm{D}-}\right.$ $\left.{ }_{2 D}=-0,34\right)$, indicando a tendência de esverdeamento da cor da rocha, o que talvez esteja associada a proliferação de colonização biológica em função do aumento da matéria orgânica na superfície da rocha ( $O$ aumento dos valores de $L^{*}$ coincidem com o aumento dos valores de $a^{\star}$ ). Todos os locais, com exceção do $D$, apresentaram aumento na cromacidade $\mathrm{b}^{\star}$, como mostra a Figura 79 e os valores dos deltas $\left(\Delta \mathrm{b}^{*}{ }_{3 \mathrm{~A}-2 \mathrm{~A}}=0,06 ; \Delta \mathrm{b}^{*}{ }_{3 \mathrm{~B}-2 \mathrm{~B}}=\right.$ 0,$\left.18 ; \Delta b^{*}{ }_{3 c-2 c}=0,80\right)$, evidenciando o amarelamento da rocha. Os valores de $H^{\circ}$ permanecem altos (superiores a $80^{\circ}$ ), apresentando um pequeno aumento em relação aos dados obtidos anteriormente, indicando também o amarelamento de todos os locais.

$\mathrm{Na}$ Figura 80 nota-se que todos os locais apresentam um pequeno aumento da reflectância espectral a partir dos $490 \mathrm{~nm}$ (comprimento de onda que corresponde ao azul), sendo o Local D o que mais evidencia isto.

As Figuras 81 a 83 mostram as análises realizadas no dia 14 de agosto de 2012.

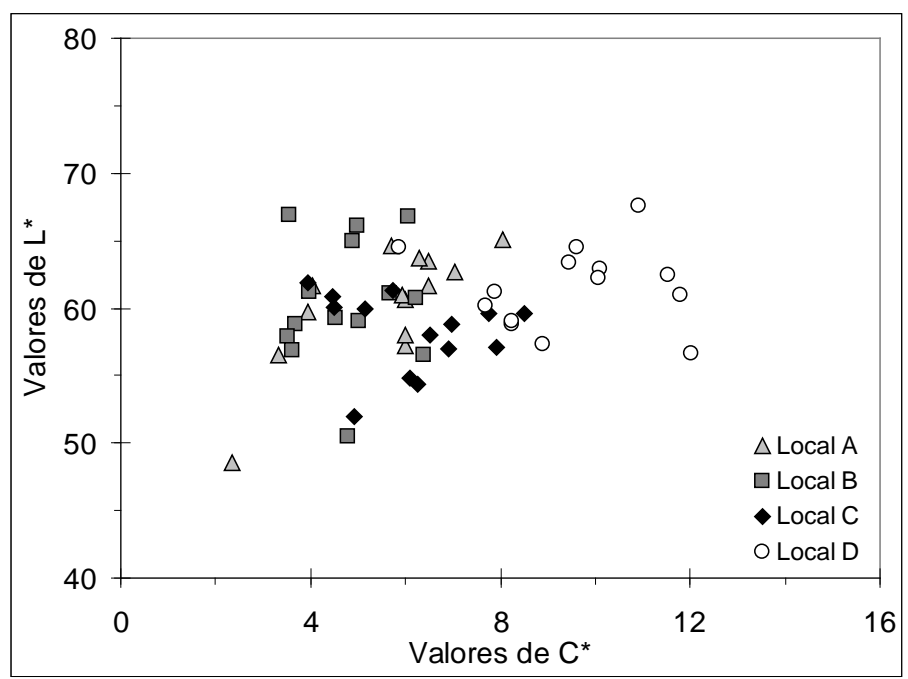

Figura 81. Diagrama de dispersão cartesiano para as variáveis C* e L* obtidas no dia 14/08/2012.

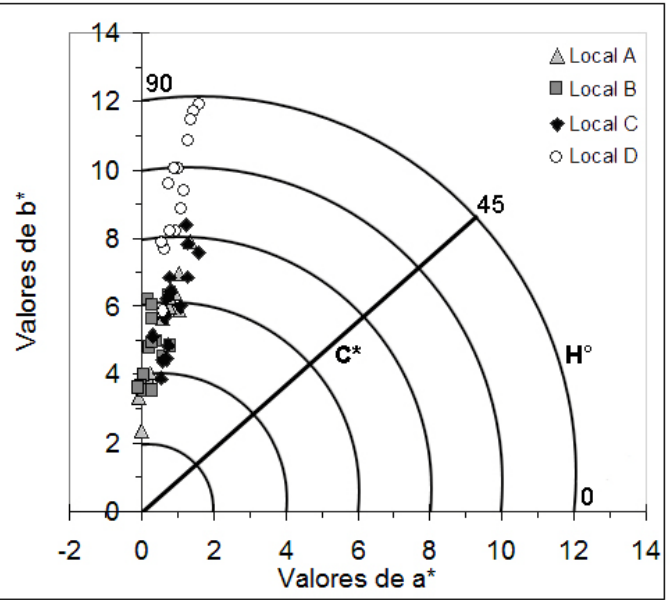

Figura 82. Diagrama de dispersão polar para as variáveis $a^{*}$ e $b^{*}$ obtidas no dia 14/08/2012. 


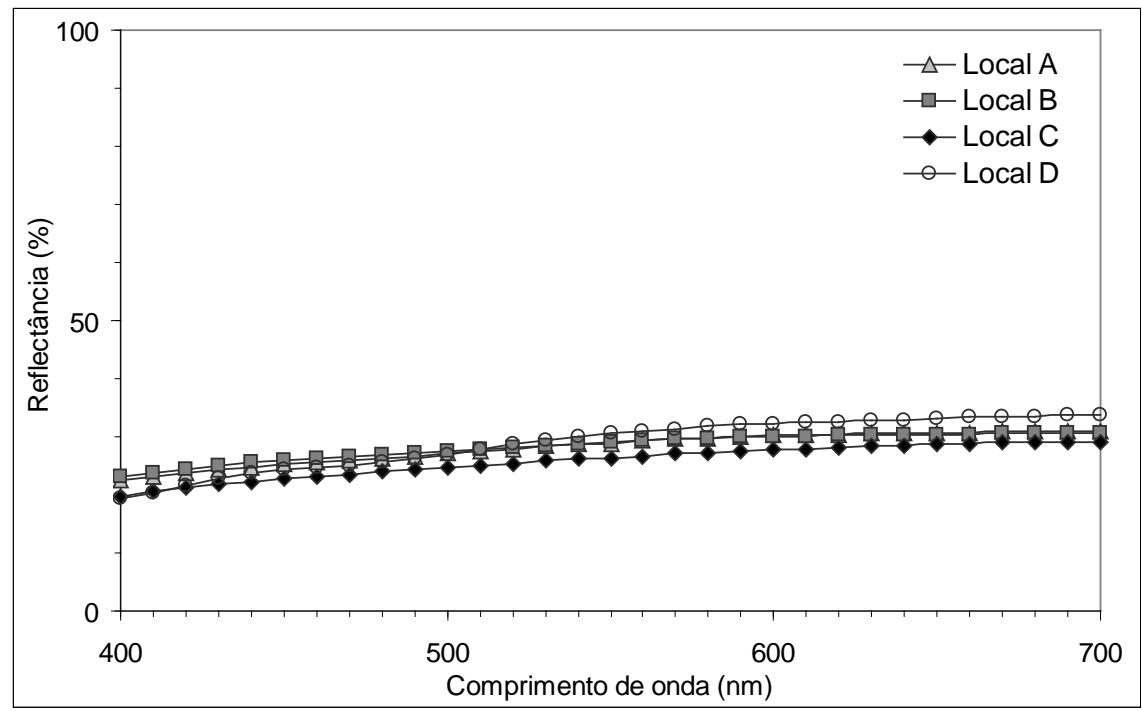

Figura 83. Gráfico de reflectância espectral para os dados obtidos nodia $14 / 08 / 2012$.

A Figura 81 e as diferenças de luminosidade indicam o clareamento da rocha nos locais A, B e D, sendo o Local B o mais claro (média de 60,47) e o local C o mais escuro (média de 58,22), em comparação com os dados obtidos anteriormente. Em todos os locais a saturação diminuiu em relação aos valores obtidos anteriormente $\left(\Delta \mathrm{C}^{*}{ }_{4 \mathrm{~A}-3 \mathrm{~A}}=-1,13 ; \Delta \mathrm{C}^{*}{ }_{4 \mathrm{~B} \text { - }}\right.$ $\left.{ }_{4 \mathrm{~B}}=-0,37 ; \Delta \mathrm{C}_{4 \mathrm{C}-3 \mathrm{C}}^{*}=-0,53 ; \Delta \mathrm{C}^{*}{ }_{4 \mathrm{D}-3 \mathrm{D}}=-0,11\right)$. Essa diminuição da saturação está ligada diretamente a diminuição da cromacidade $b^{*}$ como indicado pela Figura 82 e pelos valores das diferenças $\left(\Delta \mathrm{b}^{*}{ }_{4 \mathrm{~A}-3 \mathrm{~A}}=-1,14 ; \Delta \mathrm{b}^{*}{ }_{4 \mathrm{~B}-3 \mathrm{~B}}=-0,39 ; \Delta \mathrm{b}^{\star}{ }_{4 \mathrm{C}-3 \mathrm{C}}=-0,56 ; \Delta \mathrm{b}^{*}{ }_{4 \mathrm{D}-3 \mathrm{D}}=-0,11\right)$.

A Figura 82 mostra um pequenoaumento dos valores da cromaticidade $a^{*}$, o que é evidenciado pelos valores dos deltas $\left(\Delta \mathrm{a}^{*}{ }_{4 \mathrm{~A}-3 \mathrm{~A}}=-0,01 ; \Delta \mathrm{a}^{*}{ }_{4 \mathrm{~B}-3 \mathrm{~B}}=0,11 ; \Delta \mathrm{a}^{*}{ }_{4 \mathrm{C}-3 \mathrm{C}}=0,13 ; \Delta \mathrm{a}^{*}{ }_{4 \mathrm{D}-3 \mathrm{D}}\right.$ $=0,01)$, com os valores de $\mathrm{H}^{\circ}$ permanecendo altos.

Na Figura 83 nota-se que os locais A, B e C apresentam uma reflectância espectral homogênea em todos os comprimentos de onda, enquanto o local $D$ apresenta um aumento da quantidade de luz refletida a partir dos $490 \mathrm{~nm}$ (comprimento de onda que corresponde ao azul).

\subsubsection{Túmulo da Família Pereira Pinto (1868-1886)}

O túmulo da família Pereira Pinto foi construído entre as décadas de 1868 e 1886, tratando-se de blocos retangulares de Granito Itaquera, empilhados em quatro níveis. $\mathrm{O}$ centro mais elevado suporta três blocos de mármores, que por sua vez suportam uma cruz constituída pelo mesmo tipo de rocha (Figura 84). Pelas datas dos sepultamentos e considerando que o granito seja o mesmo da confecção do jazigo, esse túmulo pode ser considerado como uma das referências mais antigas da utilização do Granito Itaquera no 
Cemitério da Consolação. Pela iconografia interpreta-se que esse túmulo apresenta as mesmas condições ambientes desde a sua confecção, ou seja, ausência de vegetação ao redor e de estruturas que possam dificultar a iluminação de alguma das faces do túmulo grande parte do dia. Desta maneira infere-se que o intemperismo físico seja o principal agente de degradação do túmulo (Figuras 85 e 86).

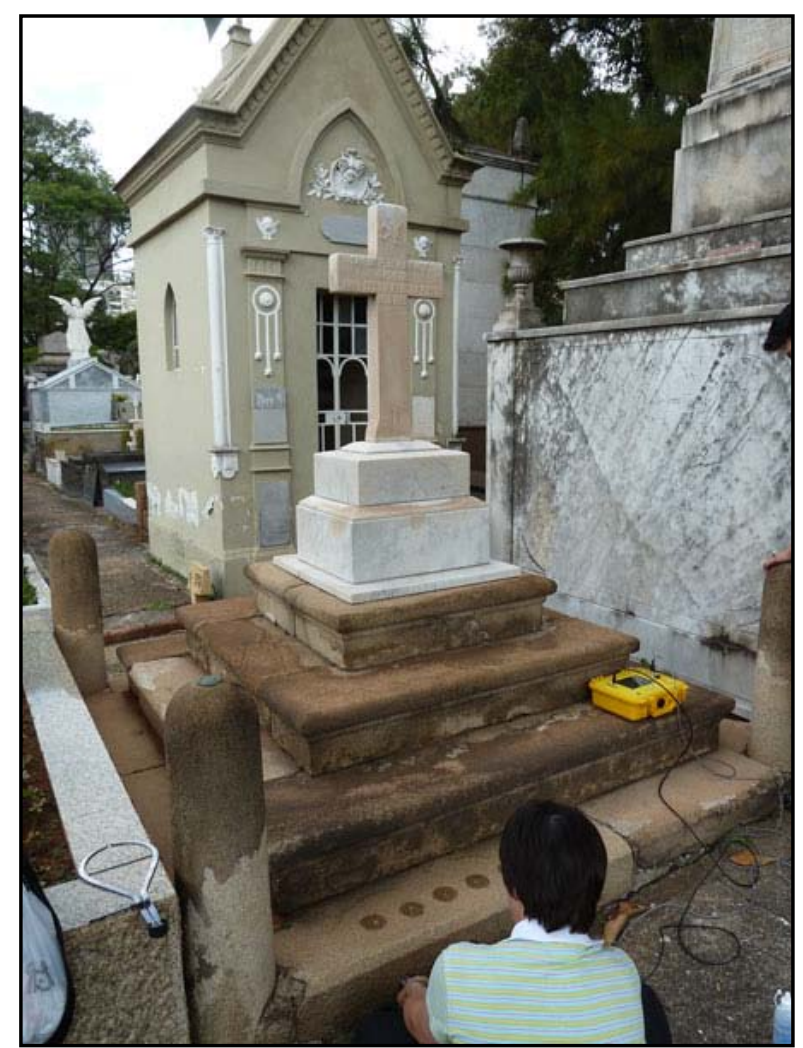

Figura 84. Túmulo da Família Pereira Pinto, notando-se intensa alteração cromática do jazigo.

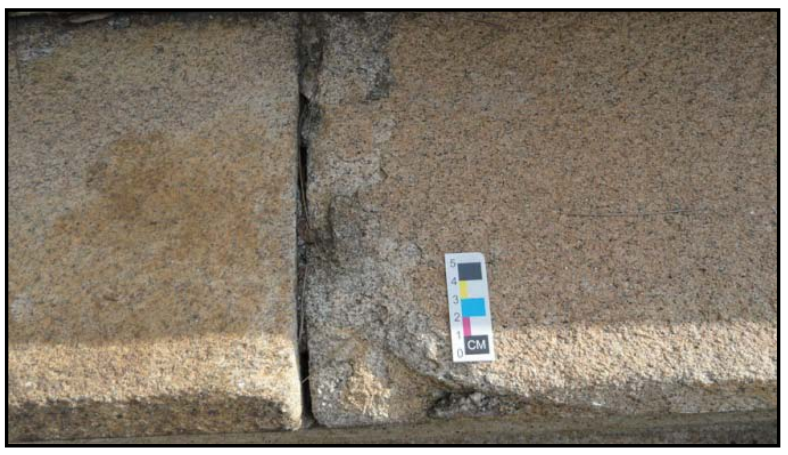

Figura 85. Perda de partes da rocha.

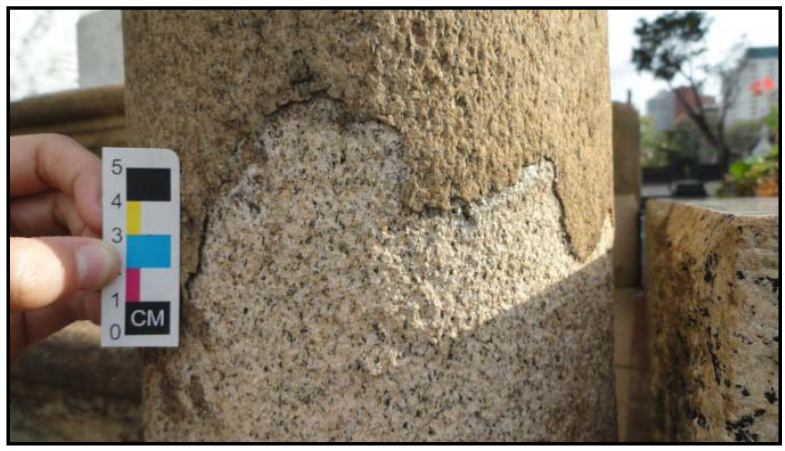

Figura 86. Descamação do granito Itaquera. 
A avaliação da homogeneidade do Granito Itaquera foi realizada com base nas velocidades das ondas ultrassônicas obtidas para ensaios realizados nos blocos do Granito Itaquera do primeiro nível e do quarto nível, conforme as Figuras 87 a 90. Esse túmulo foi estudado pelos métodos direto, semidireto e indireto.

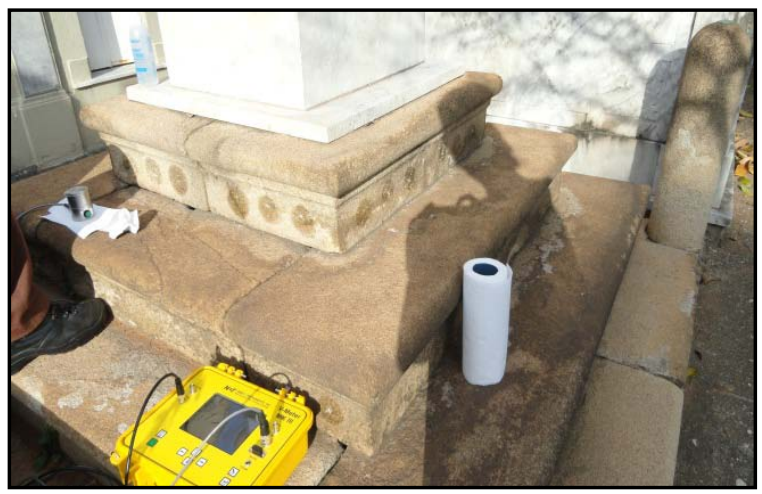

Figura 87. Primeiro nível do túmulo analisado pela velocidade das ondas ultrassônicas.

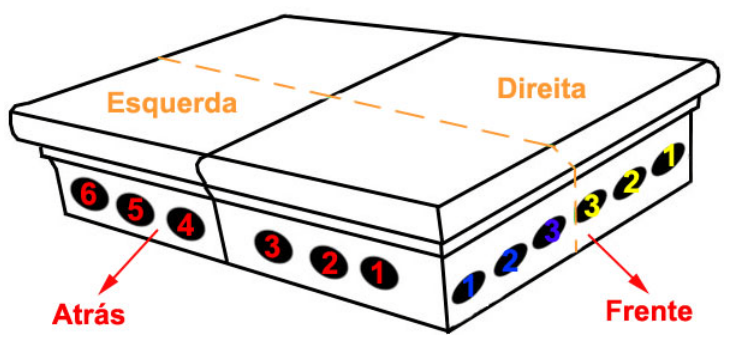

Figura 89. Esquema das análises realizadas no primeiro nível do túmulo.

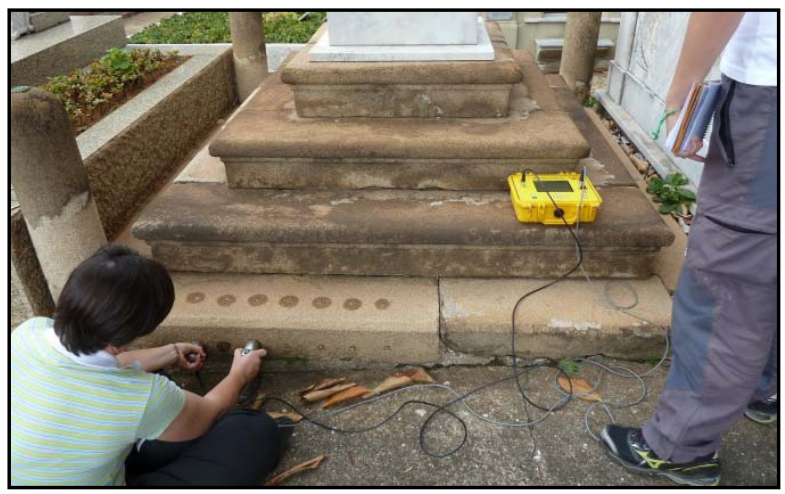

Figura 88. Quarto nível do túmulo analisado pela velocidade das ondas ultrassônicas.

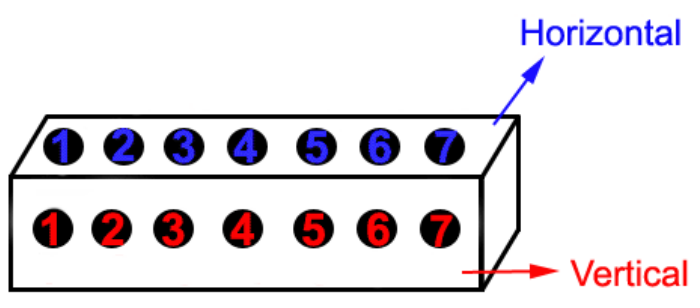

Figura 90. Esquema das análises realizadas no quarto nível do túmulo.

Os valores das velocidades médias das ondas ultrassônicas, obtidos com o transdutor de $54 \mathrm{kHz}$ pelo método de transmissão direta, semidireta e indireta são apresentados na Tabela 9. 
Tabela 9. Valores obtidos para a avaliação realizada pela velocidade das ondas ultrassônicas.

\begin{tabular}{c|c|c|c|c|}
\hline $\begin{array}{c}\text { Objeto I Método de } \\
\text { Transmissão }\end{array}$ & Transdutores & $\begin{array}{c}\text { Velocidade } \\
\text { Média (m/s) }\end{array}$ & $\begin{array}{c}\text { Desvio Padrão } \\
\text { (m/s) }\end{array}$ & $\begin{array}{c}\text { Coeficiente de } \\
\text { Variação (\%) }\end{array}$ \\
$\begin{array}{c}\text { Primeiro Nível } \\
\text { Bloco da Frente } \\
\text { Direto }\end{array}$ & $54 \mathrm{kHz}$ & 2487,4 & 32,6 & 1,3 \\
\hline $\begin{array}{c}\text { Primeiro Nível } \\
\text { Bloco de Trás } \\
\text { Direto }\end{array}$ & $54 \mathrm{kHz}$ & 3964,7 & 277,6 & 7,0 \\
\hline $\begin{array}{c}\text { Primeiro Nível } \\
\text { Bloco da Frente } \\
\text { Semidireto }\end{array}$ & $54 \mathrm{kHz}$ & 2164,9 & 644,8 & 29,4 \\
\hline $\begin{array}{c}\text { Primeiro Nível } \\
\text { Bloco de Trás } \\
\text { Semidireto }\end{array}$ & $54 \mathrm{kHz}$ & 3146,8 & 550,4 & 17,5 \\
\hline $\begin{array}{c}\text { Quarto Nível } \\
\text { Horizontal com vertical } \\
\text { Semidireto }\end{array}$ & $54 \mathrm{kHz}$ & 2322,2 & 499,8 & 21,5 \\
\hline $\begin{array}{c}\text { Quarto Nível } \\
\text { Horizontal } \\
\text { Indireto }\end{array}$ & $54 \mathrm{kHz}$ & 1273,1 & 124,3 & 9,8 \\
\hline $\begin{array}{c}\text { Quarto Nível } \\
\text { Vertical } \\
\text { Indireto }\end{array}$ & $54 \mathrm{kHz}$ & 1233,2 & 168,6 & 13,7 \\
\hline
\end{tabular}

A análise visual já indicava que os blocos apresentam-se intensamente intemperizados, o que foi confirmado pelas baixas velocidades obtidas para o primeiro e quarto nível da estrutura. Para o primeiro nível, as análises realizadas pelos métodos direto e semidireto indicaram que o bloco da frente apresenta menores velocidades que o bloco de trás, o que pode indicar maior seu grau de intemperismo. O baixo coeficiente de variação para a velocidade média obtida pelo método direto para o bloco da frente indica que o intemperismo se distribui de forma homogênea para esse bloco, enquanto o bloco de trás apresenta-se levemente mais heterogêneo que o bloco da frente. As velocidades obtidas pelo método semidireto apresentam alto coeficiente de variação, o que devido aos valores obtidos pelo método direto, devem se relacionar a limitação do método de análise.

A velocidade obtida pelo método semidireto para o quarto nível apresenta valor próximo ao obtido para o bloco da frente do primeiro nível, indicando graus de intemperismo semelhantes. Os baixos valores de velocidade obtidos pelo método indireto para análises realizadas na horizontal e vertical provavelmente estão mais relacionados a limitações do método, visto que a análise semidireta foi realizada englobando as duas regiões.

Foram avaliadas as características colorimétricas do Granito Itaquera (locais com tonalidade alaranjada clara). Os valores da estatística descritiva aplicada aos parâmetros colorimétricos $L^{*}, a^{*}, b^{*}, C^{*}$ e $H^{\circ}$ estão apresentados na Tabela 10. 
Tabela 10. Os valores da estatística descritiva aplicada aos parâmetros colorimétricos $L^{*}, a^{*}, b^{*}, C^{*} e$ $\mathrm{H}^{\circ}$ do Granito Itaquera para o túmulo da Família Pereira Pinto.

\begin{tabular}{|c|c|c|c|c|c|c|}
\hline Local de Estudo & Estatística & $\mathbf{L}^{*}$ & $\mathbf{a}^{*}$ & $\mathbf{b}^{*}$ & $\mathbf{C}^{*}$ & $\mathbf{H}^{\circ}$ \\
\hline $\begin{array}{c}\text { Todo o túmulo } \\
(14 / 08 / 2012)\end{array}$ & Média & 52,61 & 6,99 & 19,47 & 20,69 & 70,28 \\
\hline & Desvio Padrão & 1,54 & 0,82 & 1,71 & 1,87 & 1,05 \\
\hline
\end{tabular}

Os valores dos parâmetros colorimétricos $L^{*}, a^{*}, b^{*}, C^{*}$ e $H^{\circ}$ foram interpolados em diagramas de dispersão cartesianos $\left(C^{*}, L^{*}\right)$ e polares $\left(C^{*}, H^{\circ}\right)$, conforme as Figuras 91 e 92. O diagrama de dispersão dos valores do comprimento de onda na região da luz visível em função da quantidade de luz refletida está representado na Figura 93.

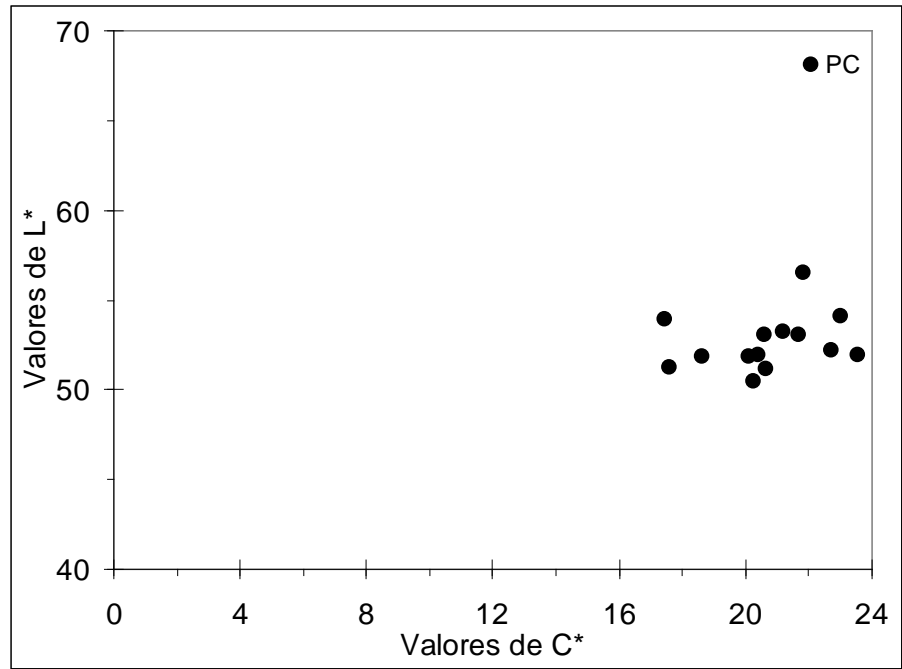

Figura 91. Diagrama de dispersão cartesiano para as variáveis $C^{*}$ e $L^{*}$.

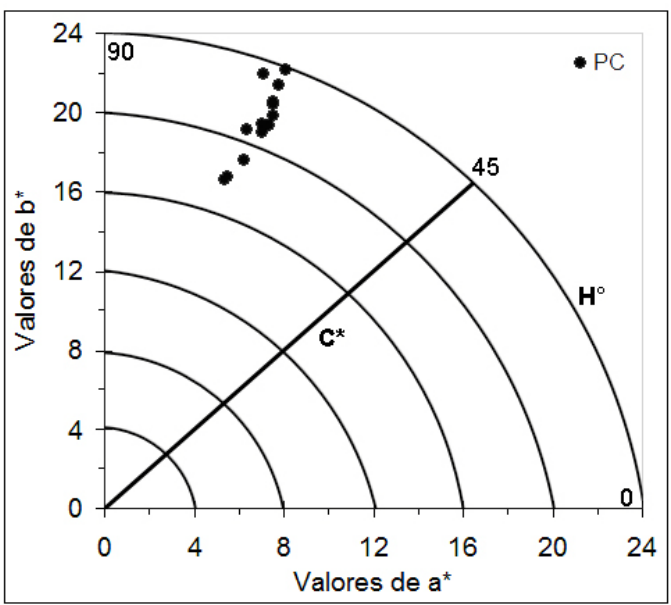

Figura 92. Diagrama de dispersão polar para as variáveis $\mathrm{C}^{\star}$ e $\mathrm{H}^{\circ}$.

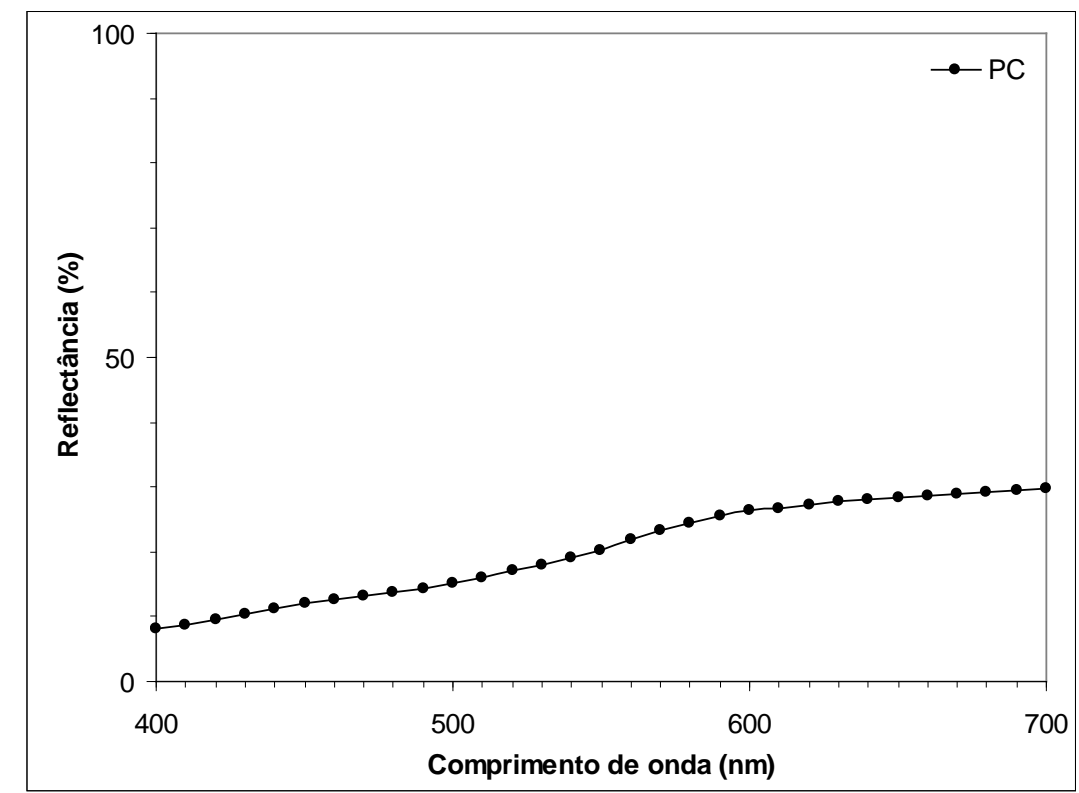

Figura 93. Gráfico de reflectância espectral. 
Os valores médios dos parâmetros $\mathrm{a}^{\star}$ e $\mathrm{b}^{\star}$, e a distribuição dos valores de $\mathrm{C}^{\star}$ e $\mathrm{H}^{\circ}$ no diagrama de dispersão polar indica tendência a uma tonalidade alaranjada, condizendo com o observado visualmente. A Figura 93 mostra uma tendência ao aumento da quantidade de luz refletida com o aumento do comprimento de onda, notando-se uma tendência ao aumento da reflectância a partir dos 600 nm (comprimento de onda da região do laranja).

A partir da interpretação de todos os dados para o Túmulo da Família Pereira Pinto pode-se concluir que:

- A análise dos padrões de degradação da rocha no Granito Itaquera indicou alta intensidade da alteração cromática para tons de amarelo e laranja, perdas de partes e escamação.

- As velocidades das ondas ultrassônicas obtidas são condizentes com o estado de conservação da rocha, apresentando baixos valores de velocidade e para o primeiro nível do túmulo, foi identificado que o bloco da frente se apresenta mais alterado que o da parte posterior.

- Os parâmetros colorimétricos obtidos são condizentes com as cores identificadas visualmente. Esses dados servirão de padrão de comparação para identificação desse padrão de alteração, ou seja, alteração cromática para tons de amarelo e laranja, em outros monumentos constituídos pelo Granito Itaquera.

\subsubsection{Estátua Cristo (1962) - Escultor Elio de Giusto}

A estátua Cristo de Elio de Giusto ornamenta o túmulo de Manoel Dias de Abreu, médico que criou a teoria da radiometria, posteriormente chamada de abreugrafia em sua homenagem (Bedrikow, 2001). Faleceu de câncer de pulmão em 30 de abril de 1962.

A estátua consiste de um Cristo com formas arredondadas, segurando na altura do queixo um objeto em forma de coração. Não há referencia em relação à data de confecção da estátua, entretanto admite-se que ela esteja relacionada ao sepultamento do falecido, o que ocorreu na década de 1960.

A estátua está em bom estado de conservação, apresentando problemas relacionados a colonização biológica por liquens (Figura 94) e alteração cromática, provavelmente também relacionada a micro-organismos, visto que na lápide do túmulo, próximo as inscrições em bronze, não há mudança significativa na cor da rocha (Figura 95). A alteração cromática e os micro-organismos concentram-se na parte superior e posterior da estátua. 


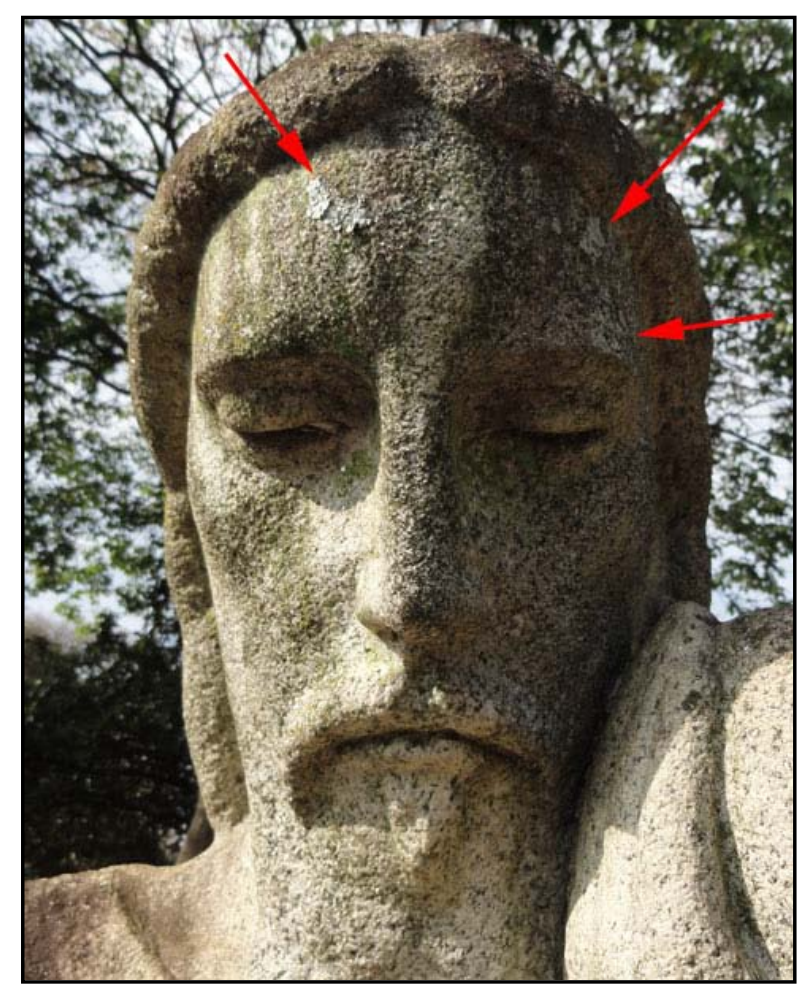

Figura 94. Notar partes esverdeadas e presença de liquens (setas vermelhas) na região da testa da estátua.

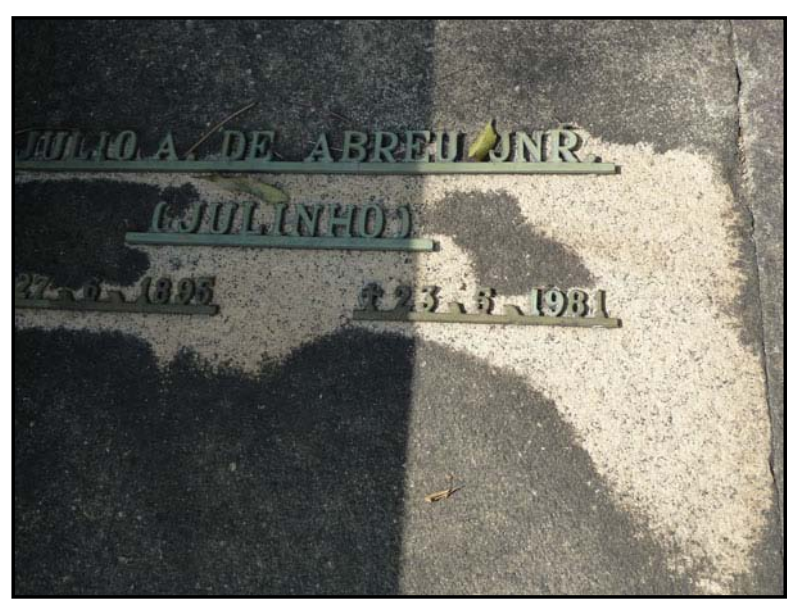

Figura 95. Partes próximas as inscrições em bronze com ausência de alteração cromática, evidenciando que a mudança na cor da rocha é devido à colonização biológica. Nesse caso o bronze funcionou como biocida natural.

A avaliação da homogeneidade do Granito Itaquera foi realizada com base nas velocidades das ondas ultrassônicas obtidas para ensaios realizados na parte central da estátua, conforme as Figuras 96 e 97 . O método de transmissão utilizado foi o direto. 


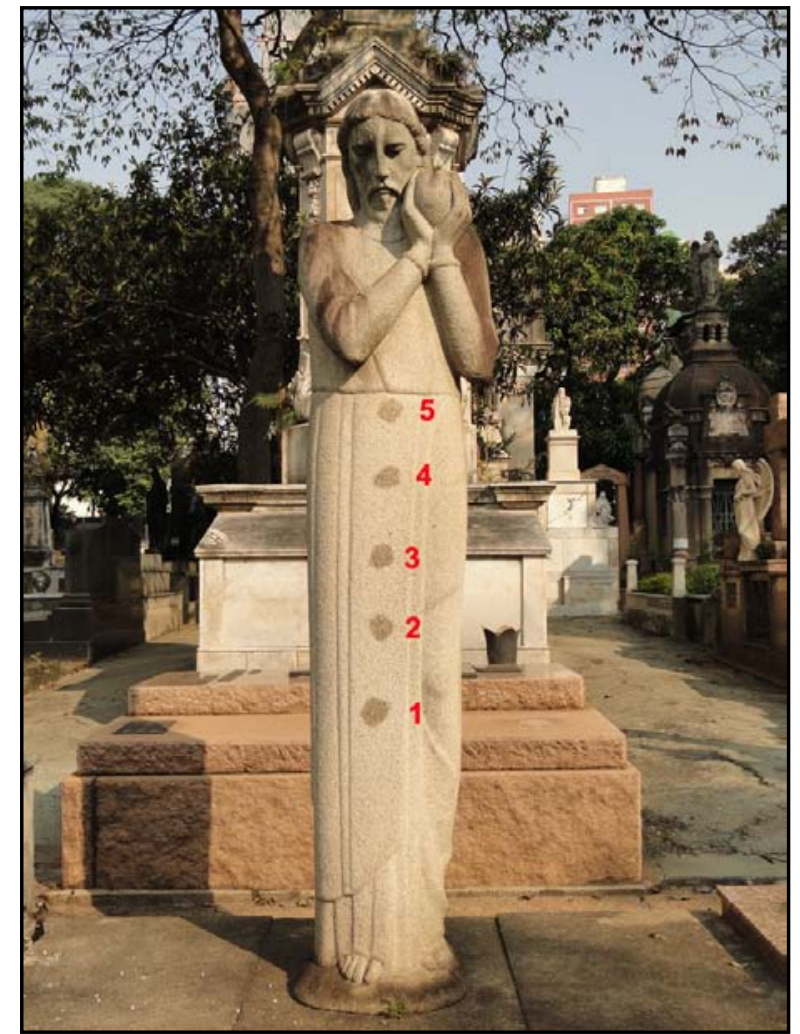

Figura 96. Localização dos pontos estudados, na parte anterior da estátua, pela velocidade das ondas ultrassônicas.

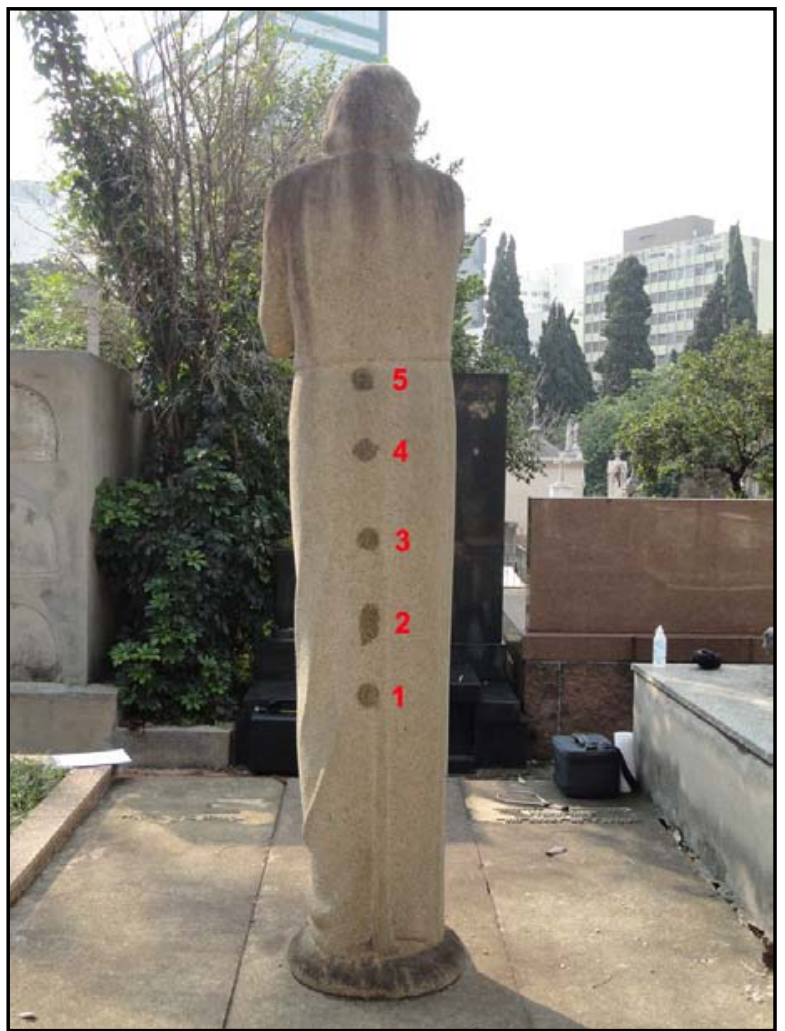

Figura 97. Localização dos pontos estudados, na parte posterior da estátua, pela velocidade das ondas ultrassônicas.

Os valores das velocidades médias das ondas ultrassônicas, obtidos com os transdutores de $54 \mathrm{kHz}$ e $150 \mathrm{kHz}$ pelo método de transmissão direta, são apresentados na Tabela 11.

Tabela 11. Valores obtidos pelo método de transmissão direta.

\begin{tabular}{c|c|c|c}
\hline Transdutores & $\begin{array}{c}\text { Velocidade Média } \\
(\mathbf{m} / \mathbf{s})\end{array}$ & Desvio Padrão (m/s) & $\begin{array}{c}\text { Coeficiente de } \\
\text { Variação (\%) }\end{array}$ \\
\hline $54 \mathrm{kHz}$ & 4679,9 & 575,0 & 12,3 \\
\hline $150 \mathrm{kHz}$ & 3207,1 & 889,1 & 27,7 \\
\hline
\end{tabular}

Nota-se que o valor obtido com o transdutor de $54 \mathrm{kHz}$ apresentou valores menorespara o desvio padrão e consequentemente para o coeficiente de variação se comparados aos obtidos com o transdutor de $150 \mathrm{kHz}$. De fato, a utilização do transdutor de $150 \mathrm{kHz}$ em campo não se mostrou muito prática para a situação de estudo, pois os tempos de percurso da onda pela rocha apresentavam grande variação para cada pulso emitido pelo aparelho em um mesmo ponto estudado. Essa dificuldade está evidente nos valores do desvio padrão e coeficiente de variação obtidos, pois os locais estudados não apresentam qualquer indício de alteração que justifique uma velocidade tão baixa. Desta forma, admite- 
se apenas a representatividade da velocidade obtida com o transdutor de $54 \mathrm{kHz}$, que é de $4680 \mathrm{~m} / \mathrm{s}$, condizente com o valor esperado para um granito são.

Foi avaliada a mudança da cor da rocha da estátua Cristo, comparando uma região aparentemente integrada com outros locais que apresentavam nítido escurecimento da superfície. Os valores da estatística descritiva aplicada aos parâmetros colorimétricos $L^{*}, a^{*}$, $b^{\star}, C^{*}$ e Hºm função dos três locais analisados estão apresentados na Tabela 12.

Tabela 12. Os valores da estatística descritiva aplicada aos parâmetros colorimétricos $L^{*}, a^{*}, b^{*}, C^{*} e$ $\mathrm{H}^{\circ}$, em função do local estudado, para a estátua Cristo do escultor Elio de Giusto.

\begin{tabular}{|c|c|c|c|c|c|c|}
\hline $\begin{array}{c}\text { Locais de Estudo I } \\
\text { Data }\end{array}$ & Estatística & $L^{*}$ & $a^{*}$ & $\mathbf{b}^{*}$ & $C^{*}$ & $\mathbf{H}^{\circ}$ \\
\hline \multirow{2}{*}{$\begin{array}{l}\text { Frente da Estátua - } \\
\text { Locaisclaros } \\
\text { (LC) / (14/08/2012) }\end{array}$} & Média & 70,06 & 2,72 & 13,09 & 13,37 & 78,27 \\
\hline & Desvio Padrão & 1,73 & 0,33 & 1,33 & 1,36 & 0,63 \\
\hline \multirow{2}{*}{$\begin{array}{l}\text { Costas da estátua - } \\
\text { Locais escuros } \\
\text { (LE) / (14/08/2012) }\end{array}$} & Média & 54,17 & 1,33 & 13,25 & 13,32 & 84,23 \\
\hline & Desvio Padrão & 3,33 & 0,31 & 0,96 & 0,95 & 1,56 \\
\hline \multirow{2}{*}{$\begin{array}{l}\text { Costas da estátua - } \\
\text { Locais bem escuros } \\
\text { (LBE) / (14/08/2012) }\end{array}$} & Média & 31,48 & 3,80 & 8,12 & 9,01 & 64,53 \\
\hline & Desvio Padrão & 3,46 & 0,66 & 1,21 & 1,02 & 5,84 \\
\hline
\end{tabular}

Os valores das diferenças dos parâmetros colorimétricos $L^{*}, a^{*}, b^{*}$ e $C^{*}$ e diferença total de cor $4 \mathrm{E}$ ), para comparações entre os locais de estudo claros (LC), escuros (LE) e bem escuros (LBE), para análises realizadas em uma mesma data são apresentados na Tabela 13.

Tabela 13. Diferenças dos parâmetros colorimétricos $L^{*}, a^{*}, b^{*}$ e $C^{*}$ e diferença total de cor $(\Delta E)$, para comparações entre os locais de estudo claros (LC), escuros (LE) e bem escuros (LBE), para análises realizadas em uma mesma data.

\begin{tabular}{c|c|c|c|c|c|}
\hline $\begin{array}{c}\text { Locais de } \\
\text { Comparação }\end{array}$ & $\boldsymbol{\Delta \mathbf { L } ^ { * }}$ & $\boldsymbol{\Delta} \mathbf{a}^{*}$ & $\boldsymbol{\Delta b}^{*}$ & $\boldsymbol{\Delta} \mathbf{C}^{*}$ & $\boldsymbol{\Delta} \mathbf{E}$ \\
\hline LE-LC & $-15,89$ & $-1,39$ & 0,16 & $-0,05$ & $-15,95$ \\
\hline LBE-LC & $-38,58$ & 1,08 & $-4,97$ & $-4,36$ & $-38,91$ \\
\hline LBE-LE & $-22,69$ & 2,47 & $-5,13$ & $-4,31$ & $-23,39$ \\
\hline
\end{tabular}

Os valores dos parâmetros colorimétricos $L^{*}, a^{*}, b^{*}, C^{*} e H^{\circ}$ foram interpolados em diagramas de dispersão cartesianos $\left(C^{*}, L^{*}\right)$ e polares $\left(C^{*}, H^{\circ}\right)$ para visualização das variações desses índices em função dos diferentes locais estudadas (Figuras 98 e 99). diagrama de dispersão dos valores do comprimento de onda na região da luz visível em função da quantidade de luz refletida está representado na Figura 100. 


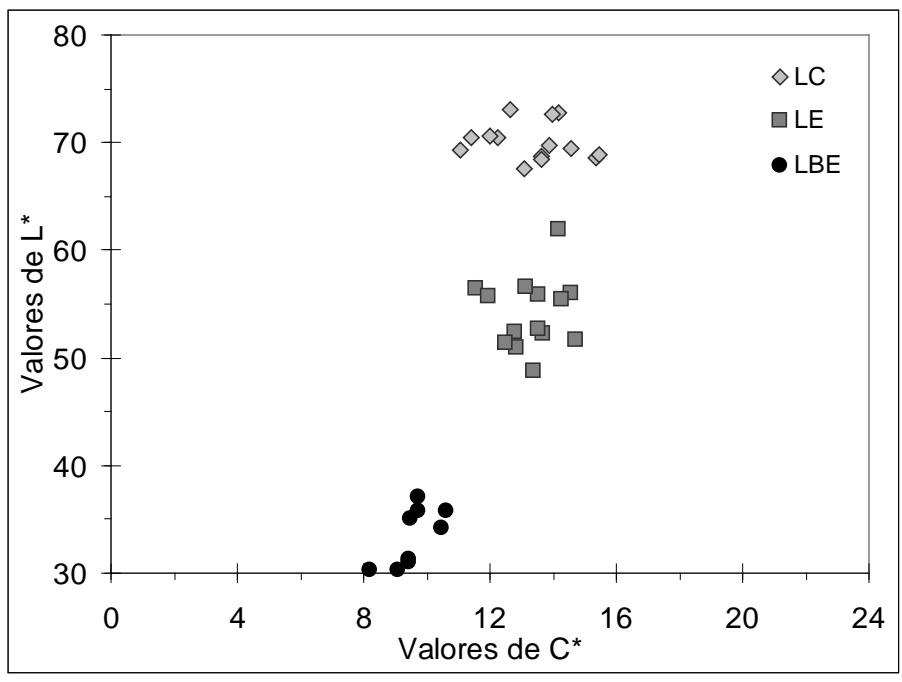

Figura 98. Diagrama de dispersão cartesiano para as variáveis $C^{*} e L^{*}$.

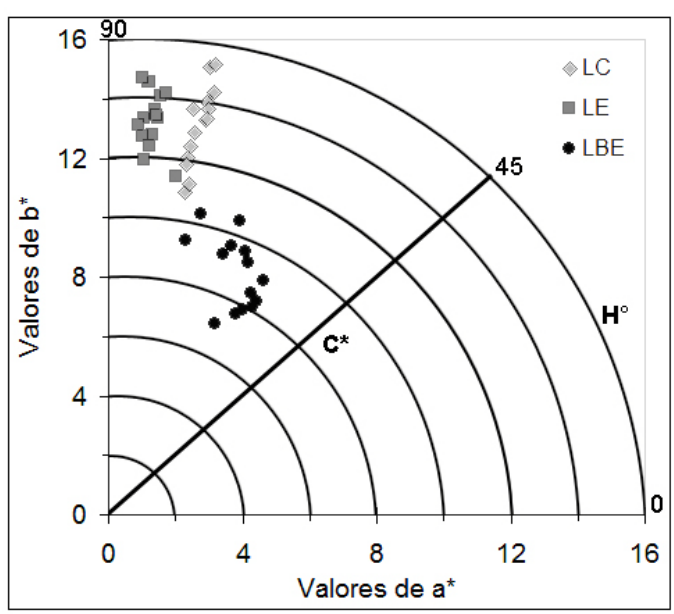

Figura 99. Diagrama de dispersão polar para as variáveis $\mathrm{C}^{\star}$ e $\mathrm{H}^{\circ}$.

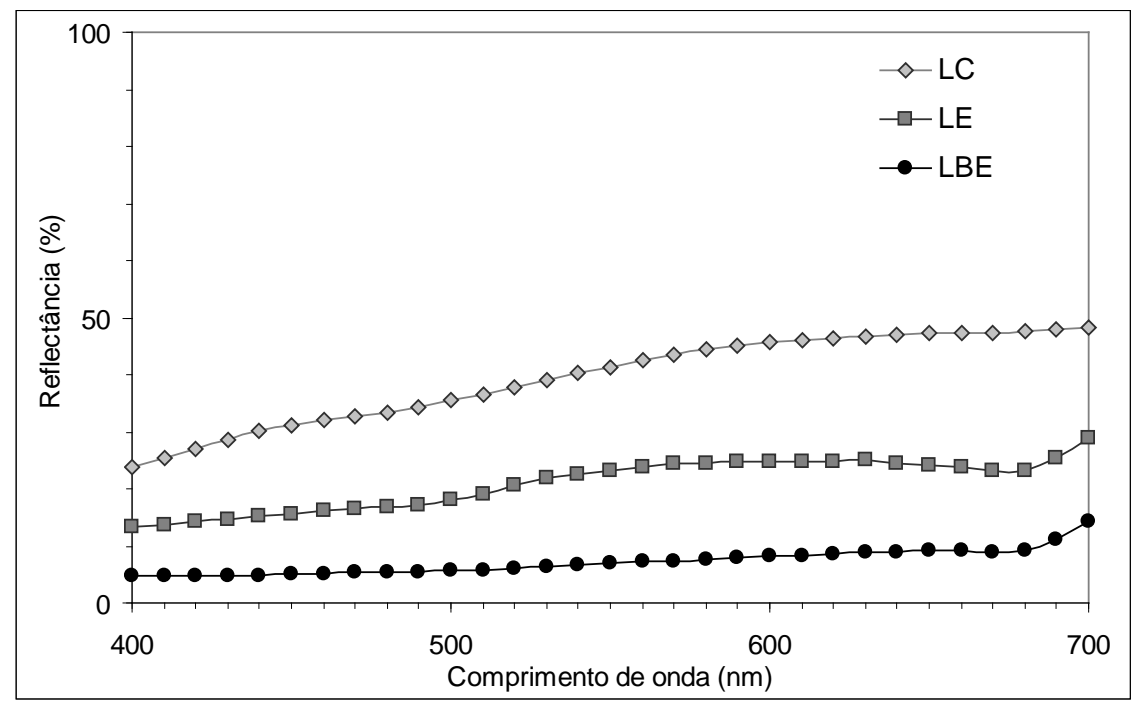

Figura 100. Gráfico de reflectância espectral.

Na Figura 98, nota-se clara diferença de luminosidade para os três locais analisados, o que já era evidente visualmente na hora da realização das análises e é comprovado pelos valores médios de $L^{*}$ presentes na Tabela 13. A saturação da cor não apresenta diferenças significativas entre os locais claros e escuros analisados $\left(\Delta C^{*}{ }_{\text {LE-LC }}=-0,05\right)$, entretanto apresenta uma sensível diminuição para os locais bem escuros $\left(\Delta C^{*}{ }_{\text {LBE-LC }}=-4,36 ; \Delta C^{*}{ }_{\text {LBE-LE }}\right.$ $=-4,31)$. A Figura 99 mostra as diferenças dos parâmetros cromacidade $a^{*}$ e $b^{\star}$ para os três locais, evidenciando que o local bem escuro apresenta uma tonalidade mais próxima ao vermelho $\left(\mathrm{H}_{\text {média }}^{\circ}=64,53\right.$ e $\left.\mathrm{a}^{*}{ }_{\text {média }}=3,80\right)$, enquanto o local escuro apresenta uma tonalidade mais próxima ao amarelo $\left(\mathrm{H}_{\text {média }}^{\circ}=84,23\right.$ e b* média $\left.=13,15\right)$.

A Figura 100mostra que o local claro é o que apresenta maior reflectância espectral em todos os comprimentos de onda se comparado aos dois outros locais, atingindo seu valor máximo em $660 \mathrm{~nm}$ (comprimento de onda da região do vermelho). O local escuro 
apresenta um sensível aumento da sua reflectância a partir dos $500 \mathrm{~nm}$ (comprimento de onda do verde), estabilizando sua reflectância nos $590 \mathrm{~nm}$ (comprimento de onda do laranja) até aos $680 \mathrm{~nm}$ (comprimento de onda do vermelho), onde ocorre novamente o aumento da reflectância. O local bem escuro apresenta uma reflectância praticamente homogênea até os $680 \mathrm{~nm}$ (comprimento de onda do vermelho) quando também apresenta um aumento da sua reflectância.

A partir da interpretação de todos os dados para a estátua Cristo pode-se concluir que:

- A análise dos padrões de degradação da rocha mostra que a parte anterior da estátua é menos afetada pela alteração cromática que a posterior, sendo que tal tipo de degradação concentra-se na sua parte superior. A colonização biológica é evidenciada na face da estátua devido a presença de liquens e em função da ausência de alteração cromática nos locais próximos às inscrições em bronze, nesse caso essa liga metálica funciona como biocida natural.

- A estátua não apresenta problemas com a sua integridade física nos locais analisados pela velocidade das ondas ultrassônicas, apresentando velocidades médias de uma rocha granítica sã.

- Os dados colorimétricos evidenciaram três locais com padrões cromáticos diferentes. A cor do local claro apresenta semelhança visual à cor esperada para uma rocha com pouca alteração cromática, podendo ser considerada a cor padrão para a estátua. Os locais escuros e bem escuros, estão localizados na parte posterior da estátua, e apesar de visualmente apresentarem distinção da sua cor apenas por diferença de luminosidade, os parâmetros colorimétricos evidenciam tendências antagônicas na variação da cor, o que leva a concluir que os mecanismos de alteração que levaram a modificação dos parâmetros colorimétricos não são iguais. Levando-se em consideração que o túmulo é afetado principalmente por colonização biológica, essas diferenças poderiam ser evidências de dois micro-organismos diferentes, entretanto para confirmar tal afirmaçãoseriam necessárias análises da composição dos dois locais, além de estudos mais aprofundados para comprovar a capacidade do espectrofotômetro de realizar tal distinção. 


\subsubsection{Estátua O Sepultamento (1923) - Escultor Victor Brecheret}

A estátua $O$ Sepultamento, também chamada de Mise Au Tombeau, de Victor Brecheret, ornamenta o túmulo de Olívia Guedes Penteado, incentivadora do modernismo no Brasil e amiga de artistas do movimento, destacando-se como: a primeira pessoa a trazer para o Brasil exemplares da obra de Pablo Picasso, Marie Laurencin, entre outros; criadora do Salão de Arte Moderna a partir de 1923; participou ativamente da revolução de 1932; e lutou tenazmente pelo voto feminino, conseguindo eleger a primeira mulher para uma constituinte.

A obra O Sepultamento é considerada uma das mais importantes de Victor Brecheret, tendo sido premiada no Salão de Outono de Paris em 1923 (Pellegrini, 2004), além de ser a obra de arte mais significativa do Cemitério da Consolação. Essa estátua representa a Pietà e as santas mulheres (Maria Madalena, Maria de Cleofás e Isabel, prima da mãe de Jesus) e uma quarta mulher, que não consta na Bíblia, que talvez seja uma alusão à D. Olívia, sua protetora nas artes. Esta é a primeira estátua do artista que apresenta sequencialidade de figuras, mais tarde adotada no Monumento às Bandeiras, tratando-se da obra que tirou Brecheret do anonimato.

O estado de conservação dessa estátua foi inicialmente estudado por Santos (2005) e posteriormente por Kuzmickas e Del Lama (2009), mostrando uma deterioração progressiva ao longo do tempo, principalmente no quesito do aumento da alteração cromática e da colonização biológica. A estátua possui ao seu redor túmulos com mais de $3 \mathrm{~m}$ de altura, o que impossibilita a sua iluminação grande parte do dia, colaborando com a presença de umidade constante. A Figura 101 retrata a parte posterior da estátua em 2008, sendo possível notar locais com amarelamento e no canto inferior direito o escurecimento da superfície devido principalmente à colonização biológica e a depósitos de fuligem (Figura 102). A Figura 103 retrata a parte posterior da estátua em 2013, notando-se o aumento da alteração cromática em quatro anos e ainda a presença de uma escada apoiada no jazigo. A Figura 104 é um detalhe da mesma região da Figura 102, notando-se aumento da degradação da área. 


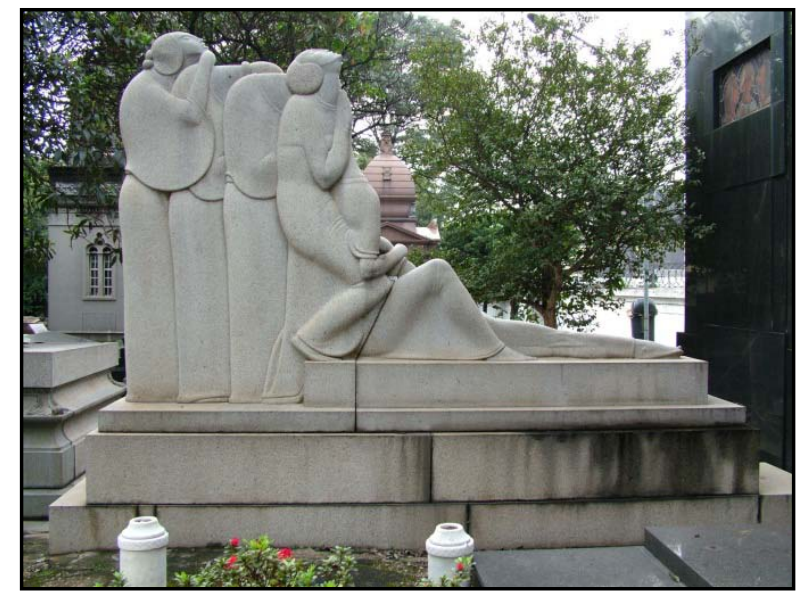

Figura 101. Parte posterior da estátua fotografadano dia 21/08/2008.

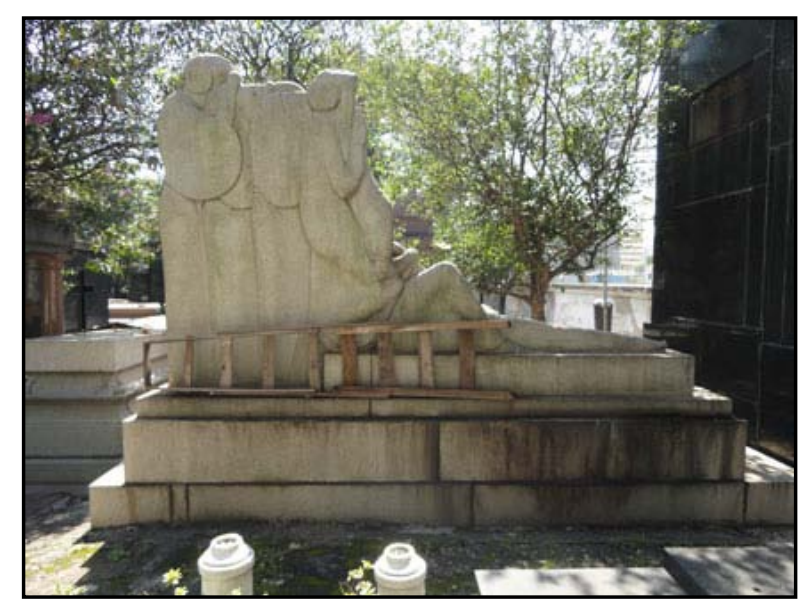

Figura 103. Parte posterior da estátua fotografada no dia 08/03/2013.

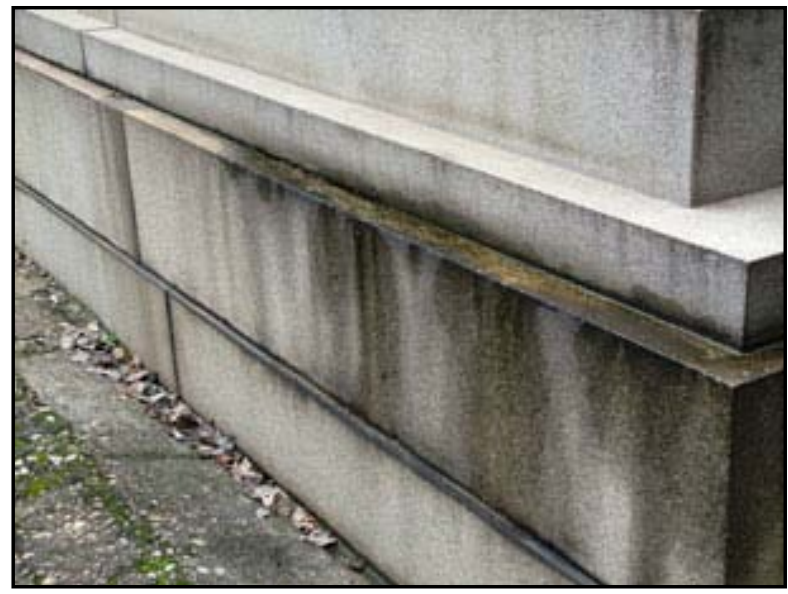

Figura 102. Detalhe da região do túmulo com maior degradação, apresentando uma alteração cromática bastante evidente.

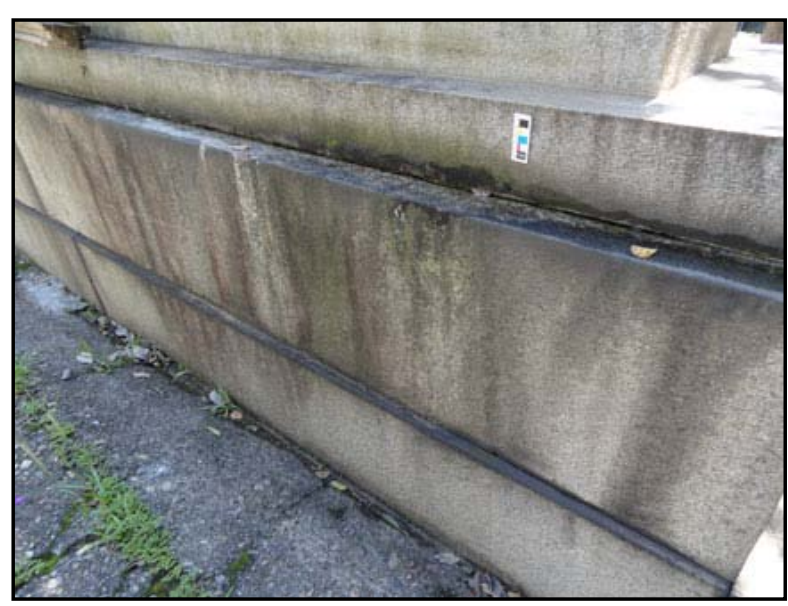

Figura 104. Detalhe da mesma região já bastante degrada em 2008, notando-se o aumento das dimensões da alteração cromática.

A avaliação da homogeneidade do Granito Itaquera foi realizada com base nas velocidades das ondas ultrassônicas obtidas para os ensaios realizados por toda a estátua em duas datas diferentes conforme as Figuras 105 (análise realizado no dia 03/04/2012) e 106 (análise realizada no dia 01/08/2012). O método de transmissão utilizado foi o direto. 


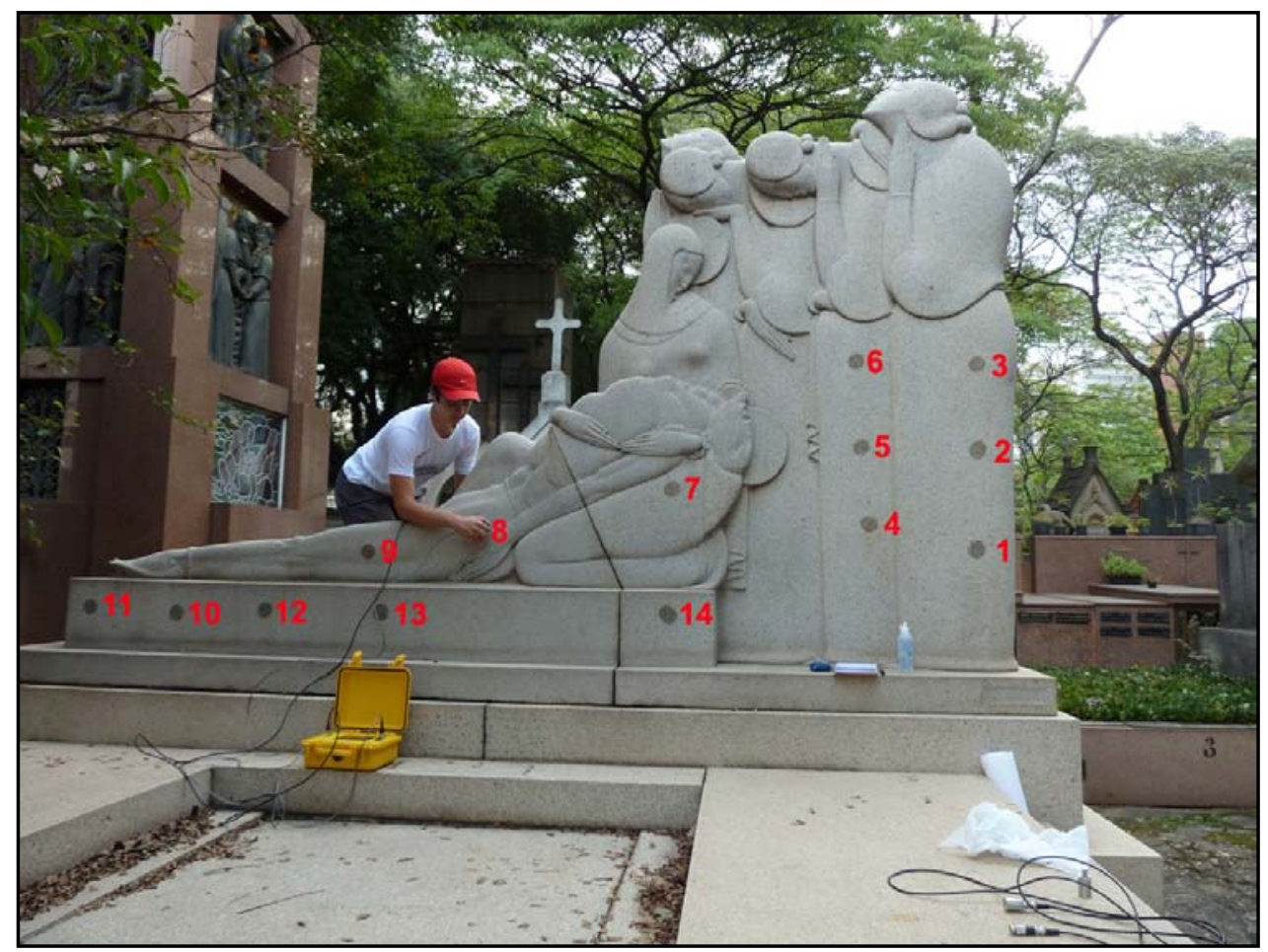

Figura 105. Localização dos pontos estudados no dia 03/04/2012, pela velocidade das ondas ultrassônicas.

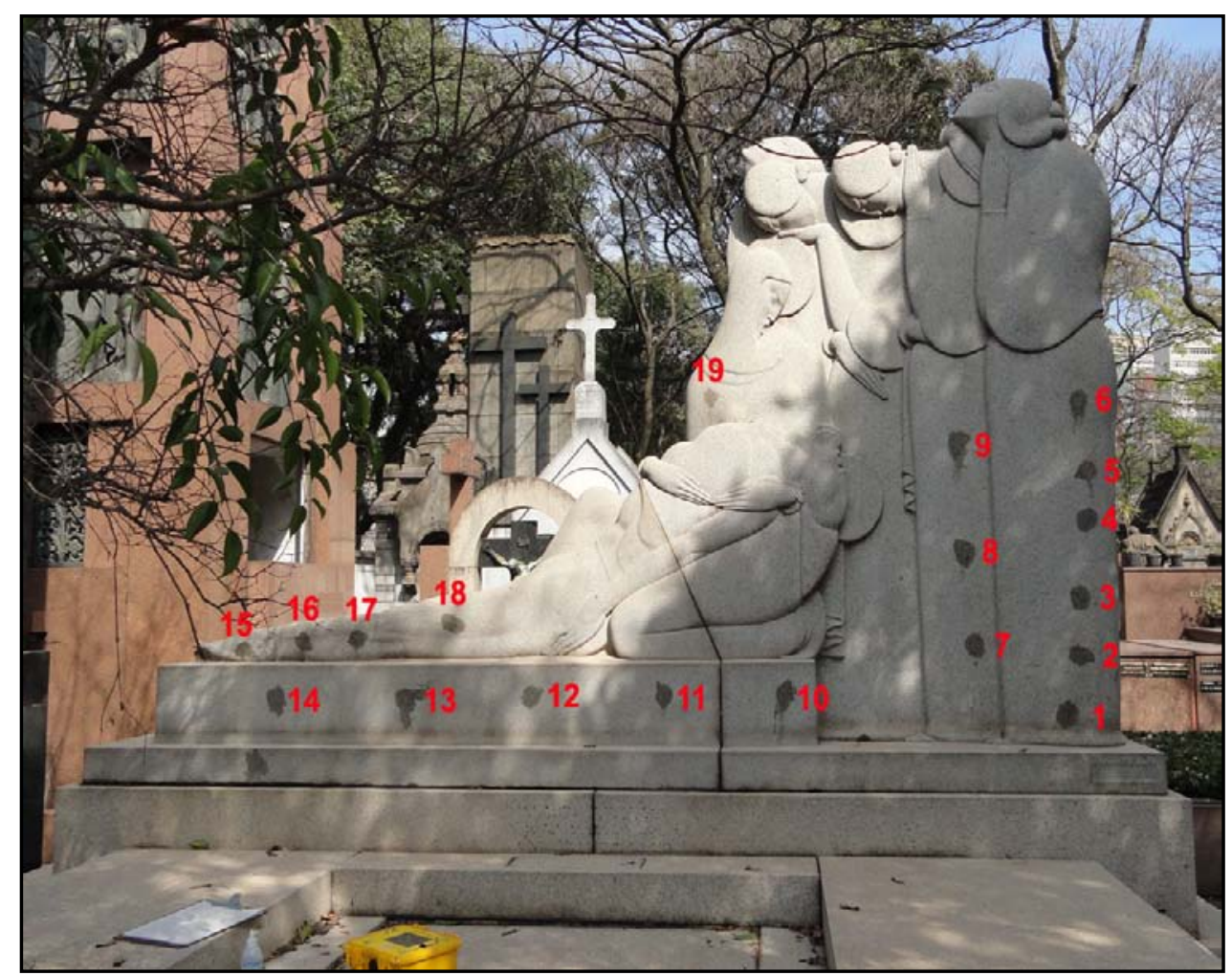

Figura 106. Localização dos pontos estudados no dia 01/08/2012, pela velocidade das ondas ultrassônicas. 
A localização dos pontos estudados com o transdutor de $54 \mathrm{kHz}$ e os valores das velocidades das ondas ultrassônicas, obtidas em cada ponto, estão representadas nas Figuras 107 e 108.

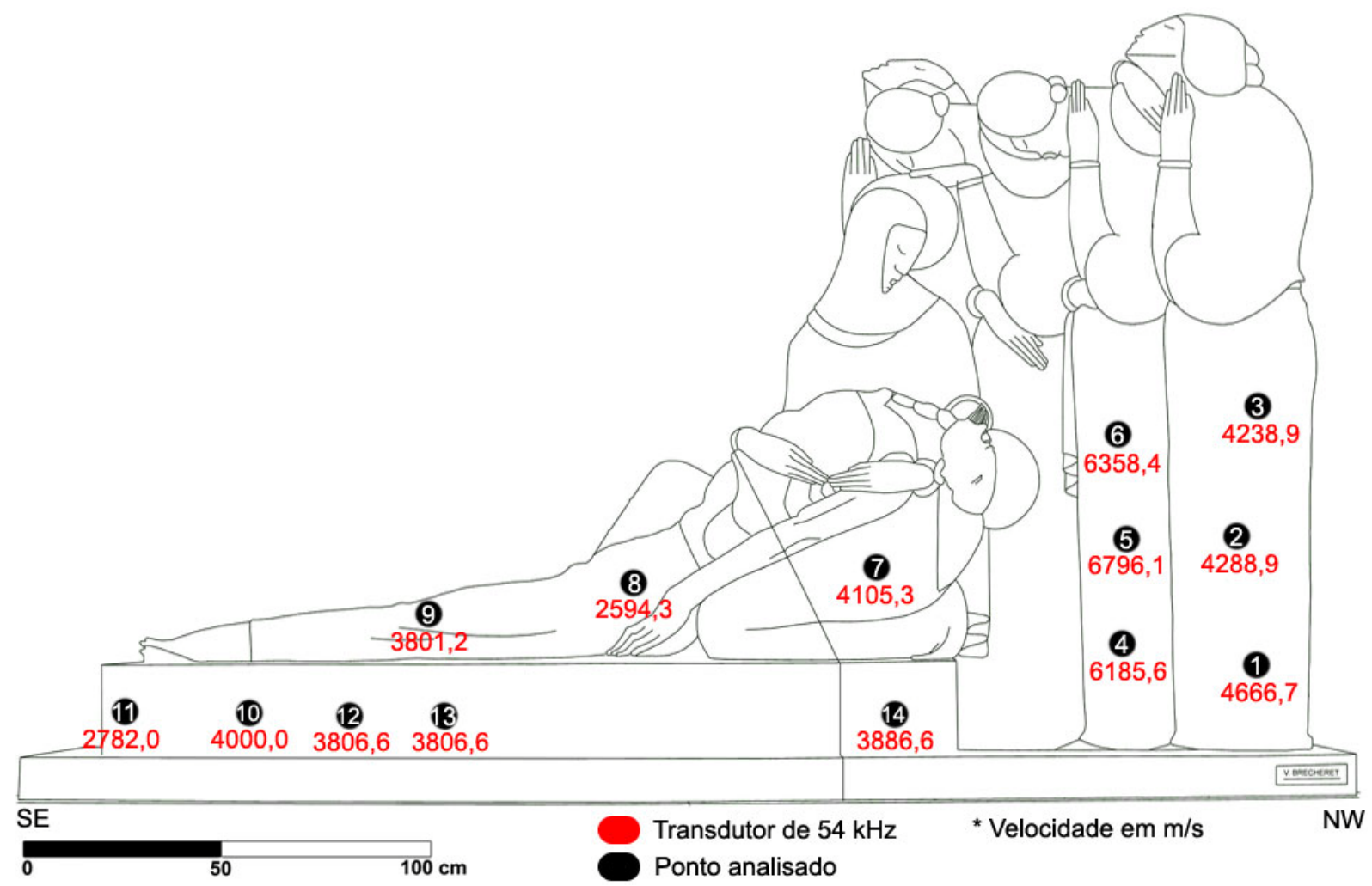

Figura 107. Localização dos pontos estudados no dia 03/04/2012 e valores das velocidades das ondas ultrassônicas calculadas.

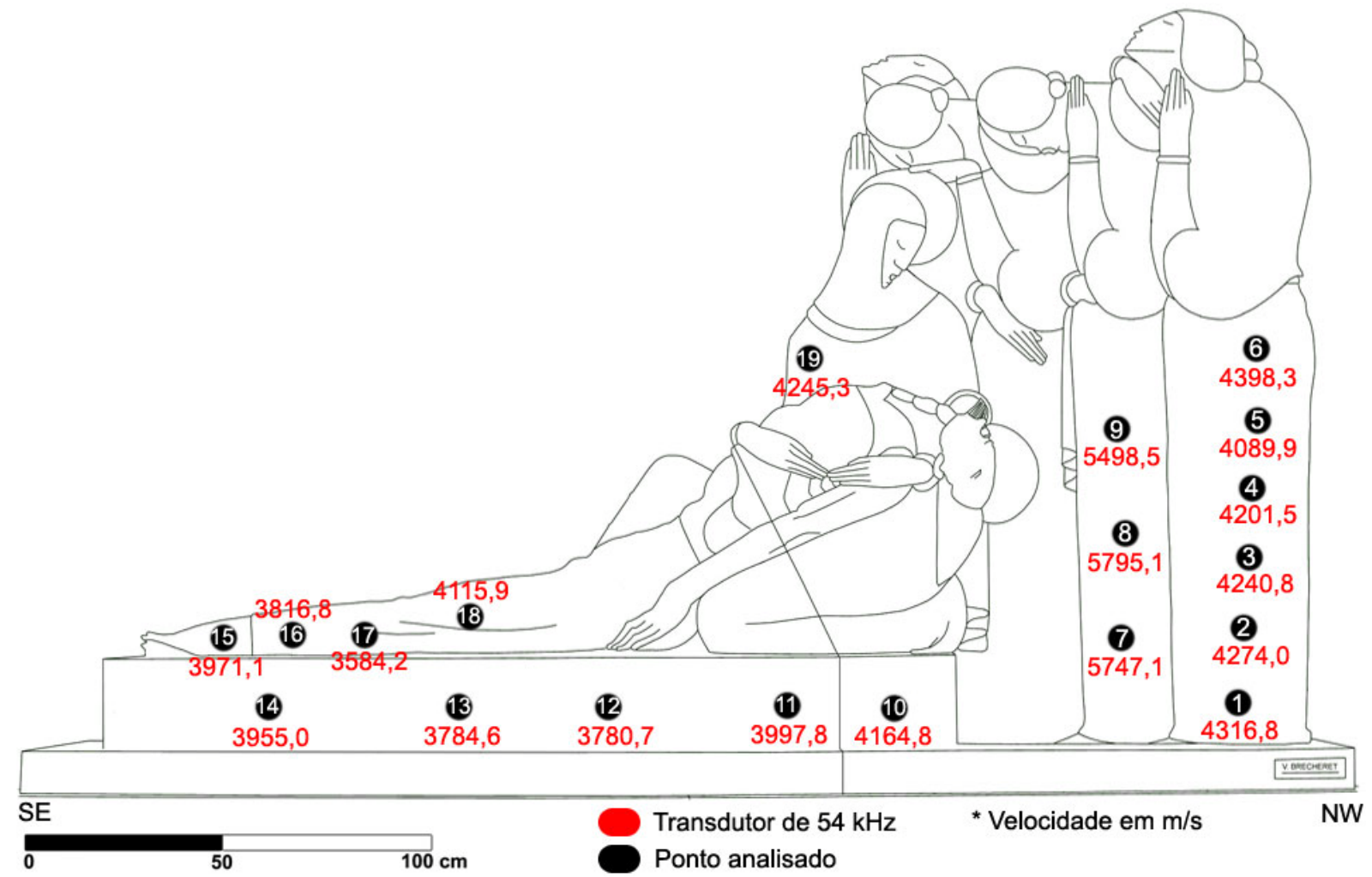

Figura 108. Localização dos pontos estudados no dia 01/08/2012 e valores das velocidades das ondas ultrassônicas calculadas. 
A localização dos pontos estudados com o transdutor de $150 \mathrm{kHz}$ e os valores das velocidades das ondas ultrassônicas, obtidas em cada ponto, estão representadas nas Figuras 109 e 110.

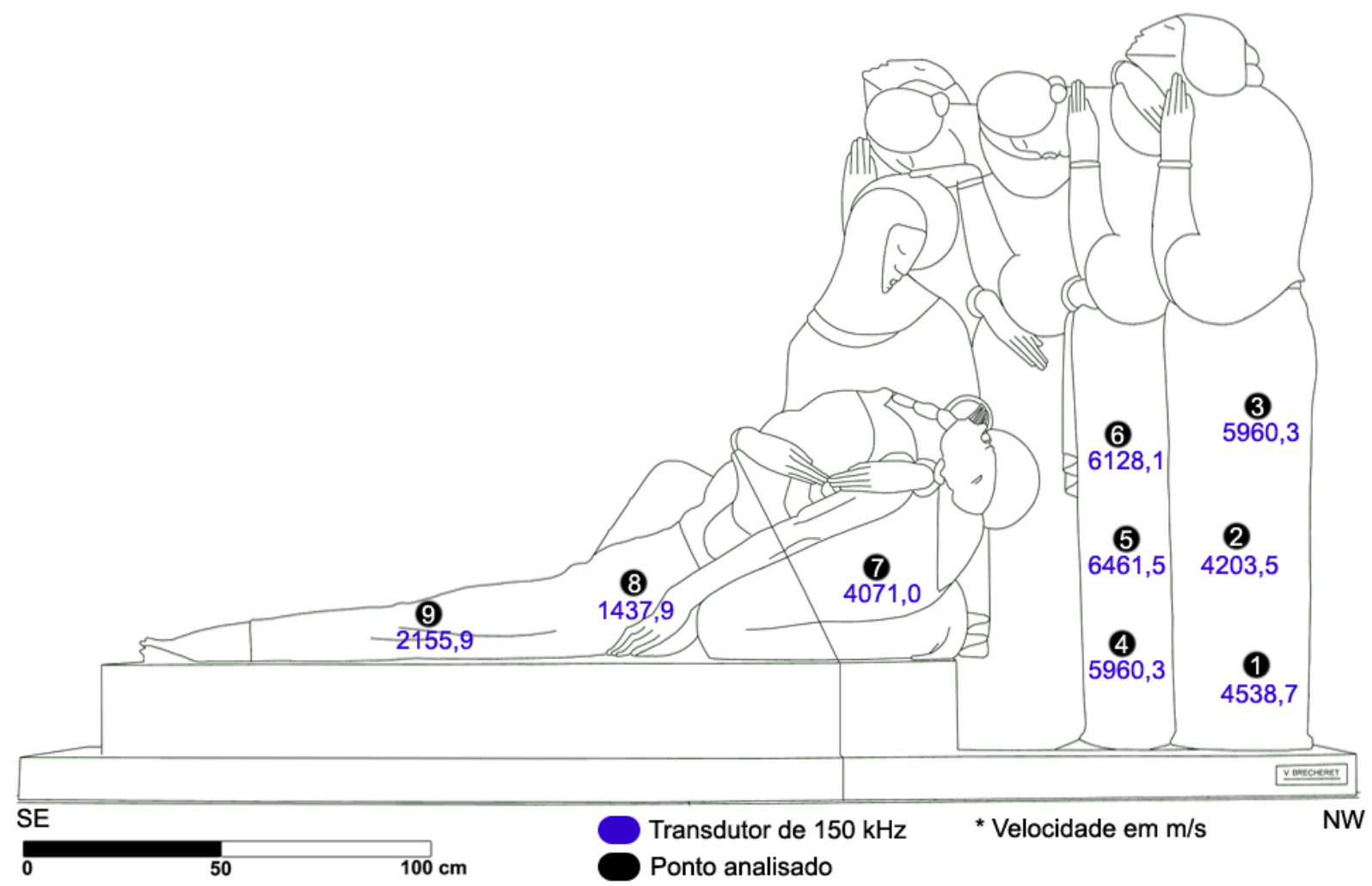

Figura 109. Localização dos pontos estudados no dia 03/04/2012 e valores das velocidades das ondas ultrassônicas calculadas.

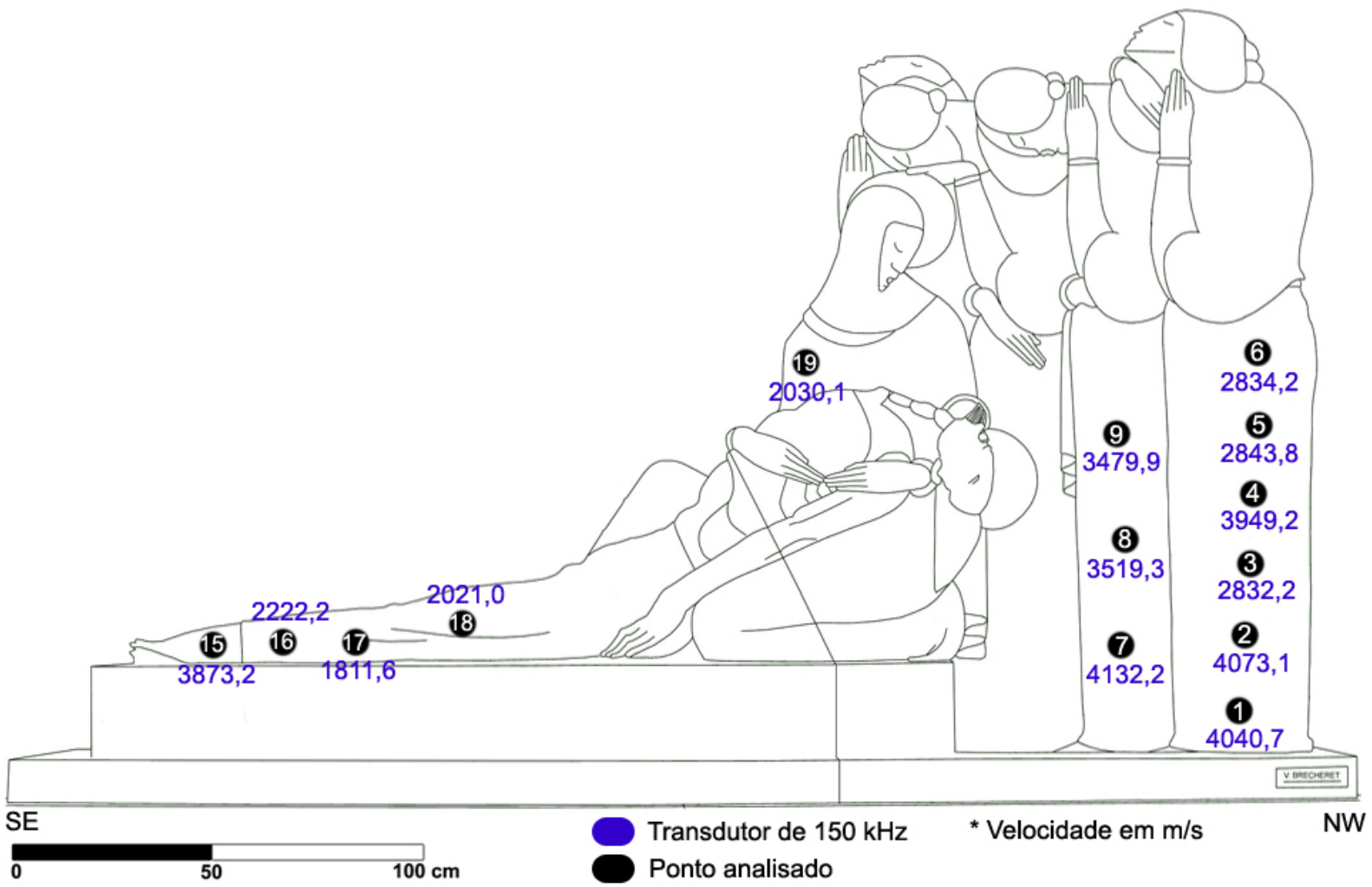

Figura 110. Localização dos pontos estudados no dia 01/08/2012 e valores das velocidades das ondas ultrassônicas calculadas. 
Os valores das velocidades médias das ondas ultrassônicas, obtidos com os transdutores de $54 \mathrm{kHz}$ e $150 \mathrm{kHz}$ pelo método de transmissão direta, são apresentados na Tabela 14.

Tabela 14. Valores obtidos para a avaliação realizada pela velocidade das ondas ultrassônicas.

\begin{tabular}{|c|c|c|c|c|}
\hline $\begin{array}{c}\text { Método de } \\
\text { Transmissão / Data }\end{array}$ & Transdutores & $\begin{array}{c}\text { Velocidade } \\
\text { Média (m/s) }\end{array}$ & $\begin{array}{c}\text { Desvio Padrão } \\
\text { (m/s) }\end{array}$ & $\begin{array}{c}\text { Coeficiente de } \\
\text { Variação (\%) }\end{array}$ \\
\hline Direta - 03/04/2012 & $54 \mathrm{kHz}$ & 4379,8 & 1250,2 & 28,5 \\
\hline Direta - 01/08/2012 & $54 \mathrm{kHz}$ & 4314,6 & 644,8 & 14,9 \\
\hline Direta - 03/04/2012 & $150 \mathrm{kHz}$ & 4344,4 & 1720,7 & 39,6 \\
\hline Direta - 01/08/2012 & $150 \mathrm{kHz}$ & 3118,8 & 853,9 & 27,4 \\
\hline
\end{tabular}

Nota-se que as velocidades médias obtidas com o transdutor de $54 \mathrm{kHz}$ apresentam menores valores do desvio padrão e consequentemente do coeficiente de variação, do que as obtidas com o transdutor de $150 \mathrm{kHz}$. Da mesma maneira como ocorreu na estátua Cristo, o transdutor de $150 \mathrm{kHz}$ apresentou grande variação do tempo de percurso da onda pela rocha, para cada pulso emitido pelo aparelho, em um mesmo ponto estudado, mesmo para os locais que não apresentavam indícios de alteração. Desta maneira admiti-se maior representatividade dos valores obtidos com o transdutor de $54 \mathrm{kHz}$, notando que as médias das velocidades obtidas nos dias 03/04/2012 e 01/08/2012, portanto com quatro meses de diferença, apresentam valores próximos (4379,8m/s e 4314,6m/s respectivamente), mesmo com a diferença de aproximadamente $15 \%$ no coeficiente de variação da primeira análise para a segunda.

As Figuras 107 a110 mostram que comparativamente as velocidades obtidas com o transdutor de $54 \mathrm{kHz}$ são superiores às obtidas com o transdutor de $150 \mathrm{kHz}$ para o mesmo ponto estudado, entretanto a variação da velocidade de um ponto para outro (aumento ou diminuição sem levar em consideração o valor), desde que o mesmo esteja próximo, apresenta certa correspondência. Isso mostra que análises realizadas com dois transdutores diferentes podem ajudar a evidenciar a perda da homogeneidade da rocha em determinados locais, o que não seria possível com a utilização de apenas um transdutor, pois tais variações poderiam ser associadas com limitações do método utilizado.

Em relação à variação pontual da velocidade, os locais correspondentes a orientação NW da estátua (Pontos 1 ao 6 para a análise realizada no dia 03/04/2012 e pontos 1 ao 9 para as análises realizadas no dia 01/08/2012) apresentam as maiores velocidades, correspondendo ao estado de conservação da rocha nos locais analisados, em contrapartida, locais próximos a orientação SE da estátua (Pontos 9 ao 11 para a análise 
realizada no dia 03/04/2012 e pontos 14 ao 17 para as análises realizadas no dia 01/08/2012) apresentam as menores velocidades, o que pode corresponder a perda de resistência da rocha, visto que tal região apresenta colonização biológica, depósitos de fuligem e alteração cromática intensa. Os locais analisados nas partes interiores da estátua (Pontos 4 ao 6 para a análise realizada no dia 03/04/2012 e pontos 7 ao 9 para as análises realizadas no dia 01/08/2012) apresentam velocidades maiores que as demais, podendo indicar maior consistência da rocha nas partes interiores do que nas bordas da estátua.

Foi avaliada a mudança da cor da rocha da estátua, comparando locais com nítida variação de cor, compreendendo: a frente da estátua (apresenta um leve amarelamento), costas da estátua (locais que apresentam apenas um leve escurecimento, apresentando tonalidade próxima a da frente da estátua), locais com colonização biológica nas costas da estátua (apresenta uma tonalidade esverdeada) e locais nas costas da estátua limpos (após a utilização do ultrasom, os pontos analisados foram limpos com água e escova de cerdas macias para a remoção do gel utilizado nas análises, esses locais ficavam bastante claros, apresentando tonalidade próxima a da parte da frente da estátua). Os valores da estatística descritiva aplicada aos parâmetros colorimétricos $L^{*}, a^{*}, b^{*}, C^{*}$ e $H^{\circ}$ em função dos locais analisados estão apresentados na Tabela 15.

Tabela 15. Os valores da estatística descritiva aplicada aos parâmetros colorimétricos $L^{*}, a^{*}, b^{\star}, C^{*} e$ $\mathrm{H}^{\circ}$, em função do local estudado, para a estátua O Sepultamento de Victor Brecheret.

\begin{tabular}{c|c|c|c|c|c|c}
\hline Local de Estudo & Estatística & $\mathbf{L}^{*}$ & $\mathbf{a}^{*}$ & $\mathbf{b}^{*}$ & $\mathbf{C}^{*}$ & $\mathbf{H}^{\circ}$ \\
\hline \multirow{2}{*}{ Frente da Estátua (F) } & Média & 64,17 & 1,78 & 9,20 & 9,40 & 80,38 \\
\cline { 2 - 7 } & Desvio Padrão & 4,77 & 1,40 & 3,08 & 3,30 & 4,46 \\
\hline \multirow{2}{*}{ Costas da Estátua (C) } & Média & 52,11 & $-0,20$ & 14,77 & 14,78 & 90,61 \\
\cline { 2 - 7 } & Desvio Padrão & 4,29 & 0,50 & 2,13 & 2,13 & 1,96 \\
\hline $\begin{array}{c}\text { Costas da Estátua - } \\
\text { Locais com Colonização } \\
\text { Biológica (CCB) }\end{array}$ & Média & 29,04 & $-1,15$ & 18,40 & 18,44 & 93,47 \\
\hline $\begin{array}{c}\text { Costas da Estátua - } \\
\text { Locais limpos (CL) }\end{array}$ & Desvio Padrão & 4,01 & 0,77 & 2,52 & 2,54 & 2,19 \\
\hline & Mesvio Padrão & 3,69 & 0,49 & 0,80 & 0,80 & 2,75 \\
\hline
\end{tabular}


Os valores das diferenças dos parâmetros colorimétricos $L^{*}, a^{*}, b^{*}$ e $C^{*}$ e diferença total de cor $4 \mathrm{E}$ ), para compara̧ões entre todos os locais de estudo, para análises realizadas na mesma data (14/08/2012), são apresentados na Tabela 16.

Tabela 16. Diferenças dos parâmetros colorimétricos $L^{*}, a^{\star}, b^{\star}$ e $C^{*}$ e diferença total de cor $(\Delta \mathrm{E})$, para comparações entre a frente da estátua $(F)$, costas da estátua $(C)$, costas da estátua com colonização biológica (CCB) e costas da estátua limpa (CL), para análises realizadas em uma mesma data.

\begin{tabular}{c|c|c|c|c|c|}
\hline $\begin{array}{c}\text { Locais de } \\
\text { Comparação }\end{array}$ & $\mathbf{\Delta \mathbf { L } ^ { * }}$ & $\mathbf{\Delta} \mathbf{a}^{*}$ & $\boldsymbol{\Delta} \mathbf{b}^{*}$ & $\mathbf{\Delta \mathbf { C } ^ { * }}$ & $\boldsymbol{\Delta} \mathbf{E}$ \\
\hline C-F & $-12,06$ & $-1,98$ & 5,57 & 5,38 & 13,43 \\
\hline CCB-F & $-35,13$ & $-2,93$ & 9,20 & 9,04 & 36,43 \\
\hline CL-F & 0,15 & $-0,98$ & 1,04 & 0,88 & 1,44 \\
\hline CCB-C & $-23,07$ & $-0,95$ & 3,63 & 3,66 & 23,37 \\
\hline CL-C & 12,21 & 1,00 & $-4,53$ & $-4,50$ & 13,06 \\
\hline CL-CCB & 35,28 & 1,95 & $-8,16$ & $-8,16$ & 36,26 \\
\hline
\end{tabular}

Os valores dos parâmetros colorimétricos $L^{*}, a^{*}, b^{*}, C^{*}$ e $H^{\circ}$ foram interpolados em diagramas de dispersão cartesianos $\left(C^{*}, L^{*}\right)$ e polares $\left(C^{*}, H^{\circ}\right)$ para visualização das variações desses índices em função dos diferentes locais estudadas (Figuras 111e 112). O diagrama de dispersão dos valores do comprimento de onda na região da luz visível em função da quantidade de luz refletida está representado na Figura 113.

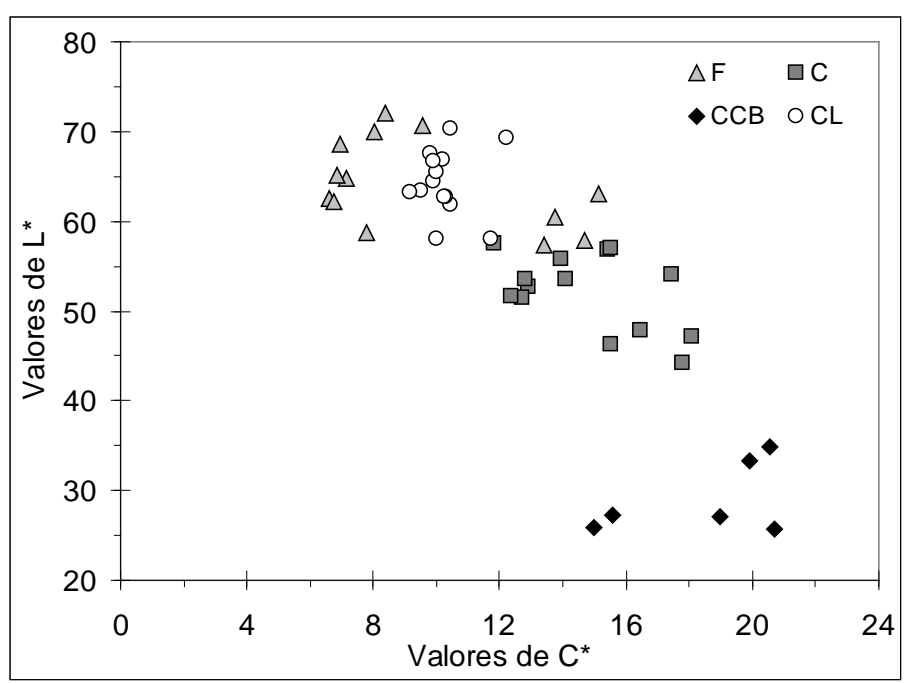

Figura 111. Diagrama de dispersão cartesiano para as variáveis $C^{*} e L^{*}$.

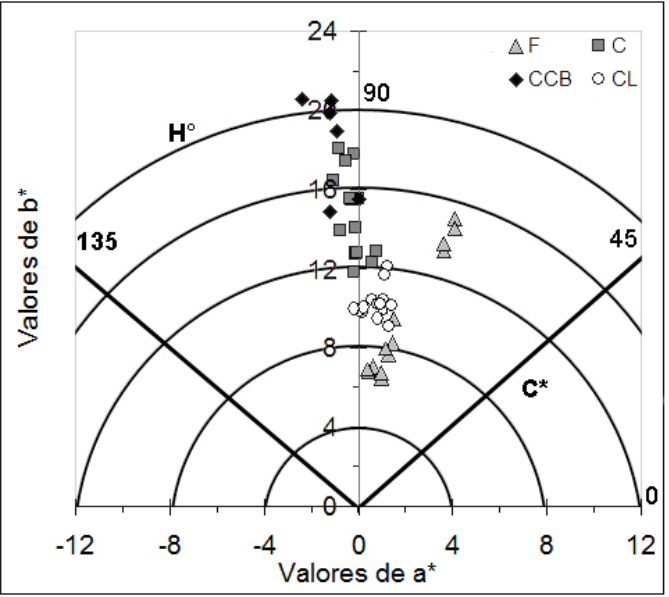

Figura 112. Diagrama de dispersão polar para as variáveis $\mathrm{C}^{*}$ e $\mathrm{H}^{\circ}$. 


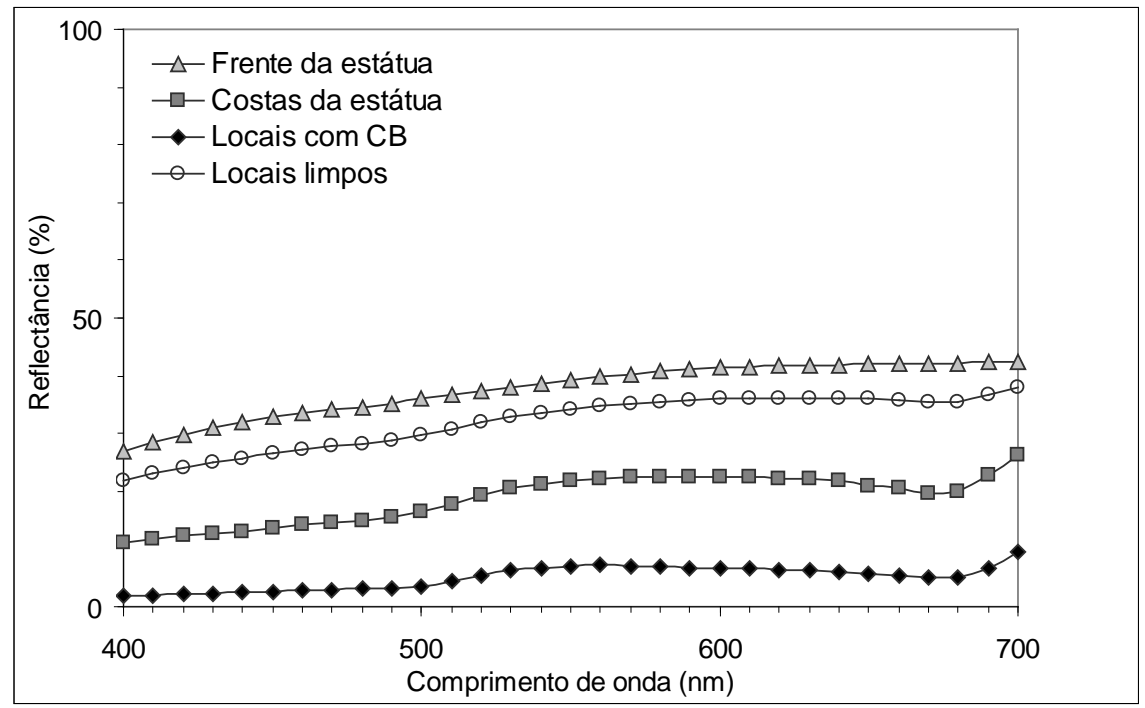

Figura 113. Gráfico de reflectância espectral.

$\mathrm{Na}$ Figura 111, nota-se clara diferença de luminosidade para os quatro locais analisados, o que já era evidente visualmente na hora da realização das análises (salvo local limpo que apresentava luminosidade muito parecida com a parte anterior da estátua) e é comprovado pelos valores médios de $L^{*}$ (presentes na Tabela 15) e pelas suas diferenças para cada local estudado (dados na Tabela 16, notando que a diferença de luminosidade da frente da estátua para os locais limpos é muito pequena, $\left.\Delta L^{*}{ }_{\mathrm{CL}-\mathrm{F}}=0,15\right)$. Os locais com colonização biológica apresentam menores valores de luminosidade e maiores valores de saturação que os locais sem colonização na parte posterior da estátua, conforme Figura 111. A saturação da cor não apresenta diferenças significativas entre a frente da estátua e os locais limpos $\left(\Delta C^{*}{ }_{C L-F}=0,88\right)$, estes apresentando uma saturação da cor levemente maior. A Figura 112 evidencia que a frente da estátua e os locais limpos apresentam valores próximos para os parâmetros $a^{*}$ e $b^{\star}\left(\Delta a^{*}{ }_{C L-F}=-0,15 ; \Delta b^{*}{ }_{C L-F}=1,04\right)$, e a parte posterior da estátua sem e com colonização biológica apresentam valores de $\mathrm{a}^{*}$ semelhantes $\left(\Delta \mathrm{a}^{*}{ }_{\mathrm{CCB}-\mathrm{C}}=\right.$ $-0,95)$ e valores de $b^{*}$ levemente superiores para locais com colonização ( $\left.\Delta b^{*}{ }_{\text {сcв-c }}=3,63\right)$. Os valores obtidos mostram que a proliferação dos micro-organismos proporcionou o amarelamento e esverdeamento da rocha, sendo que o ângulo de tonalidade superior a $90^{\circ}$, para a parte posterior com e sem colonização, evidencia esse aumento (Tabela 15).

A Figura 113 mostra que os locais limpos e a frente da estátua apresentam os maiores valores de reflectância espectral, com tendência de aumento do comprimento de onda violeta para o vermelho. As costas da estátua sem e com colonização biológica apresentam correspondência em relação ao padrão das curvas, com as costas sem colonização apresentando valores superiores de reflectância. Ambas as curvas apresentam baixa reflectância até $500 \mathrm{~nm}$ (verde), apresentando aumento até $530 \mathrm{~nm}$ (verde), estabilizando e 
sofrendo pequena diminuição até $680 \mathrm{~nm}$ (vermelho), quando apresenta um aumento mais acentuado.

A partir da interpretação de todos os dados para a estátua O Sepultamento pode-se concluir que:

- A análise dos padrões de degradação da rocha mostra que a parte anterior da estátua é menos afetada pela alteração cromática que a posterior, apresentando apenas tendência ao amarelamento. A parte posterior apresenta evidente alteração cromática em função da colonização biológica e depósitos de fuligem. Esses dois agentes de degradação, adicionando-se a presença constante de umidade na parte posterior do túmulo, principalmente no canto SE orientado da estátua, colaboram com a grande descaracterização da cor da rocha, além de promover, possivelmente, maior intemperismo.

- A análise pontual da velocidade das ondas ultrassônicas, evidencia maior perda da homogeneidade da rocha nos locais mais afetados pela alteração cromática na parte posterior do túmulo. Análises pontuais em locais interiores da estátua apresentam maiores velocidades comparativamente aos pontos realizados nas bordas, mostrando uma tendência a perda da consistência do centro para as bordas da estátua.

- Os dados colorimétricos evidenciaram não apenas modificações nas cores das rochas, mas também os mecanismos envolvidos. A parte da frente da estátua não apresenta uma descaracterização da cor significativa, entretanto em alguns locais nota-se grande tendência ao amarelamento, conforme padrão visto no túmulo da família Pereira Pinto. Essa tendência merece especial atenção, justamente para evitar que a estátua venha aapresentar no futuro, padrões de deterioração agressivos que acabem por descaracterizá-la. A parte posterior apresenta significava alteração cromática em função das colonizações biológicas e depósitos de fuligem, o que proporciona diminuição da luminosidade da rocha, assim como seu esverdeamento e amarelamento. 


\subsubsection{Estátua Interrogação (1923) - Escultor Francisco Leopoldo e Silva}

A estátua Interrogação, do escultor Francisco Leopoldo e Silva, ornamenta o túmulo de Moacyr Toledo e Piza (1891-1923), advogado conceituado, que chocou a sociedade paulista após assassinar a cortesã de luxo Romilda Machiaverni, mais conhecida como Nenê Romano, e cometer suicídio em seguida.

A obra Interrogação reflete sobre quais circustâncias levam uma pessoa a cometer um crime hediondo, representando uma mulher com as pernas estiradas e a cabeça apoiada em um dos braços, posuindo aos pés uma esfera. A figuração retrata um verdadeiro ponto de interrogação.

O estado de conservação desta obra foi avaliado inicialmente por Kuzmickas e Del Lama (2009) e não apresentou variações significativas para as condições atuais. Os principais problemas existentes compreendem: alteração cromática, como alaranjamento e amarelamento da rocha (Figuras 114 e 115), devido alteração de minerais sulfetados; perda de partes, relacionada à alteração das zonas micáceas (Figura 116); e colonização biológica nos locais propícios ao acumulo de água ${ }^{1}$.

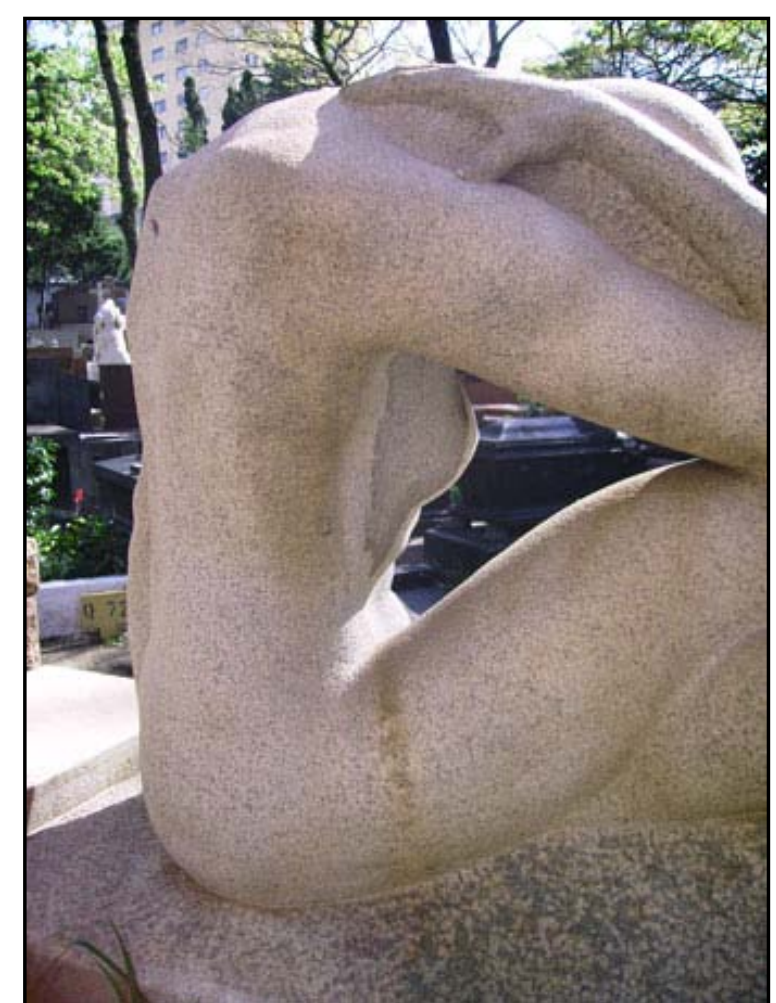

Figura 114. Alteração cromática para tons de amarelo e laranja.

\footnotetext{
${ }^{1}$ No capítulo 8.6. Características Arquitetônicas é apresentado a influência dos aspectos estéticos, da estátua Interrogação, na proliferação da colonização biológica.
} 


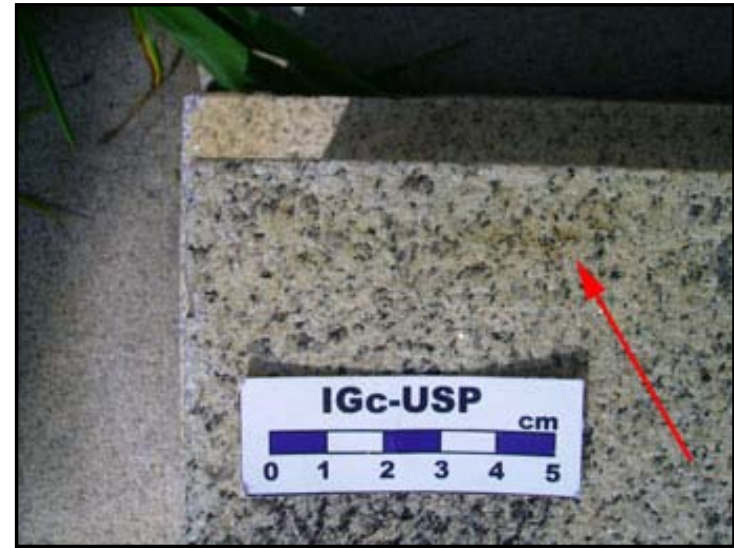

Figura 115. Alteração cromática para tons de amarelo devido à alteração de alguns minerais.

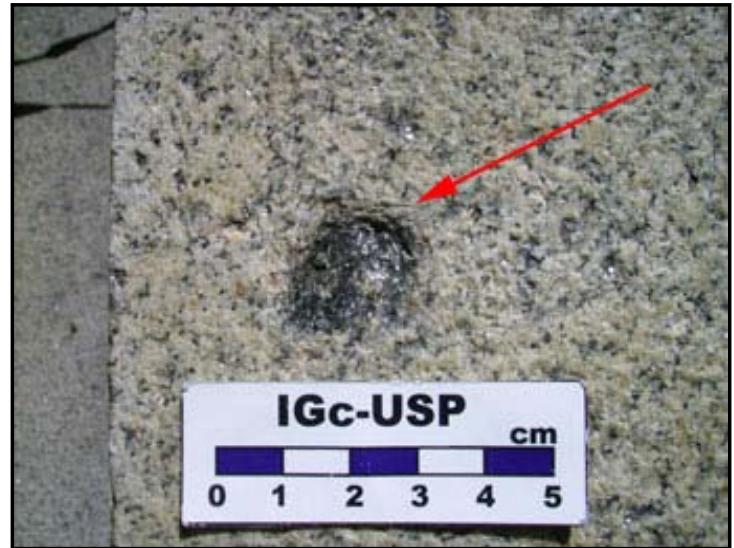

Figura 116. Perda de partes relacionada à alteração das zonas micáceas.

A avaliação da homogeneidade do Granito Itaquera foi realizada com base nas velocidades de propagação das ondas ultrassônicas, obtidas pelos métodos de transmissão direta, semidireta e indireta, que abrangeram a estátua e a estrutura que a comporta. Os pontos analisados estão referenciados na Figura 117.

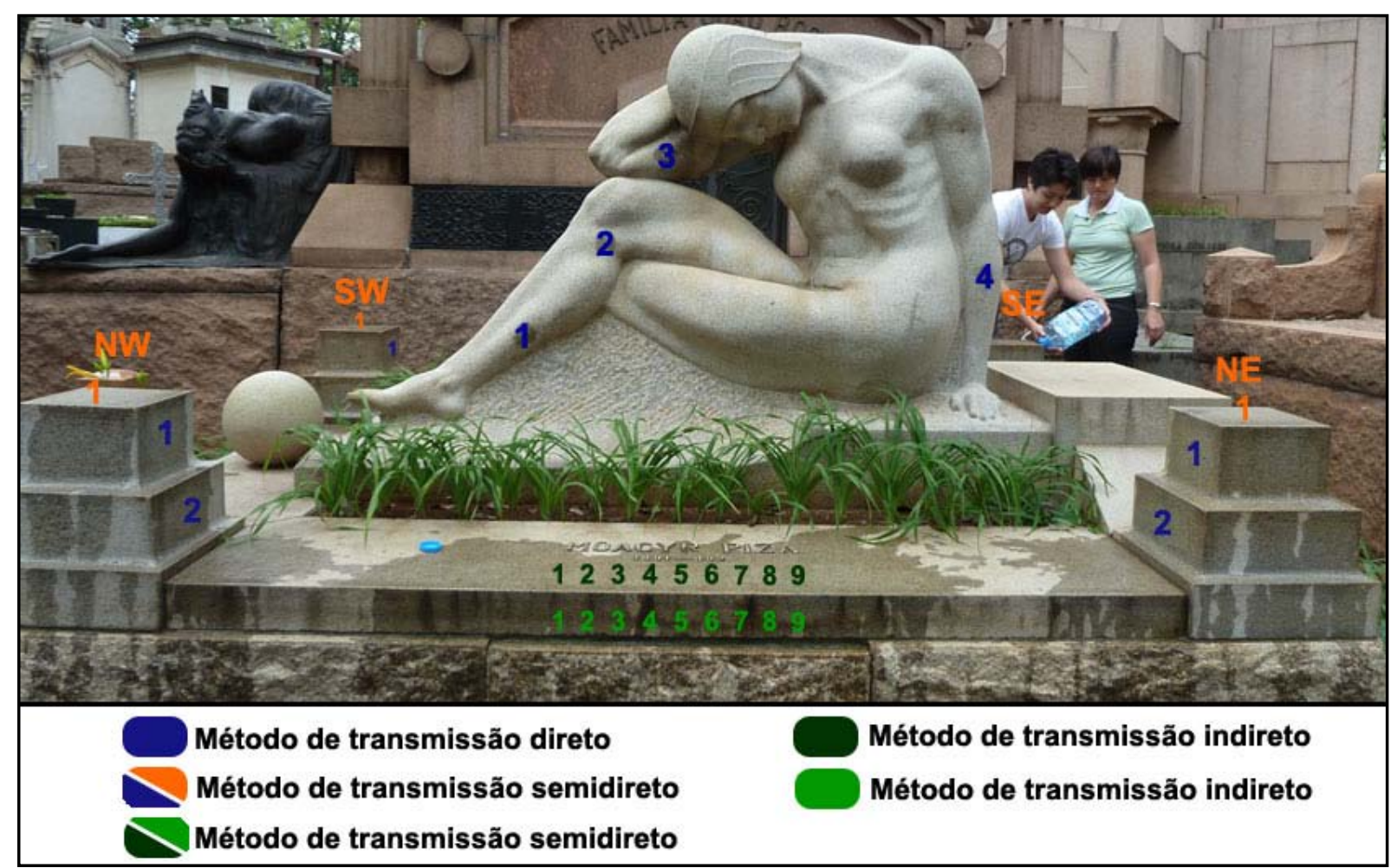

Figura 117. Locais analisados e métodos de transmissão utilizados.

Os valores da estatística descritiva aplicada às velocidades de propagação das ondas ultrassônicas obtidas nos locais analisados são apresentados na Tabela 17. 
Tabela 17. Valores obtidos para a avaliação realizada pela velocidade de propagação das ondas ultrassônicas. Estudo realizado no dia 03/04/2012.

\begin{tabular}{|c|c|c|c|c|}
\hline $\begin{array}{l}\text { Objeto I Método } \\
\text { de Transmissão }\end{array}$ & Transdutores & $\begin{array}{l}\text { Velocidade } \\
\text { Média }(\mathrm{m} / \mathrm{s})\end{array}$ & $\begin{array}{l}\text { Desvio Padrão } \\
\text { (m/s) }\end{array}$ & $\begin{array}{c}\text { Coeficiente de } \\
\text { Variação (\%) }\end{array}$ \\
\hline $\begin{array}{l}\text { Estátua } \\
\text { (Direto) }\end{array}$ & $54 \mathrm{kHz}$ & 4031,7 & 123,7 & 3,1 \\
\hline $\begin{array}{l}\text { Estátua } \\
\text { (Direto) }\end{array}$ & $150 \mathrm{kHz}$ & 4045,6 & 520,9 & 12,9 \\
\hline $\begin{array}{l}\text { Pilar NW } \\
\text { (Direto) }\end{array}$ & $54 \mathrm{kHz}$ & 3725,4 & 8,4 & 0,2 \\
\hline $\begin{array}{l}\text { Pilar NW } \\
\text { (Direto) }\end{array}$ & $150 \mathrm{kHz}$ & 4098,4 & 126,2 & 3,1 \\
\hline $\begin{array}{l}\text { Pilar NW } \\
\text { (Semidireto) }\end{array}$ & $54 \mathrm{kHz}$ & 4545,2 & 486,0 & 10,7 \\
\hline $\begin{array}{l}\text { Pilar NE } \\
\text { (Direto) }\end{array}$ & $54 \mathrm{kHz}$ & 4568,6 & 147,5 & 3,2 \\
\hline $\begin{array}{l}\text { Pilar NE } \\
\text { (Direto) }\end{array}$ & $150 \mathrm{kHz}$ & 2800,5 & 409,8 & 14,6 \\
\hline $\begin{array}{l}\text { Pilar NE } \\
\text { (Semidireto) }\end{array}$ & $54 \mathrm{kHz}$ & 4606,3 & 214,2 & 4,7 \\
\hline $\begin{array}{l}\text { Pilar SW } \\
\text { (Direto) }\end{array}$ & $54 \mathrm{kHz}$ & 4678,7 & 45,1 & 1,0 \\
\hline $\begin{array}{c}\text { Pilar SW } \\
\text { (Direto) }\end{array}$ & $150 \mathrm{kHz}$ & 3639,2 & 152,9 & 4,2 \\
\hline $\begin{array}{l}\text { Pilar SW } \\
\text { (Semidireto) }\end{array}$ & $54 \mathrm{kHz}$ & 4720,2 & 206,6 & 4,4 \\
\hline $\begin{array}{c}\text { Pilar SE } \\
\text { (Direto) }\end{array}$ & $54 \mathrm{kHz}$ & 4031,7 & 53,9 & 1,3 \\
\hline $\begin{array}{l}\text { Pilar SE } \\
\text { (Direto) }\end{array}$ & $150 \mathrm{kHz}$ & 4321,0 & 15,1 & 0,3 \\
\hline $\begin{array}{c}\text { Pilar SE } \\
\text { (Semidireto) }\end{array}$ & $54 \mathrm{kHz}$ & 4259,4 & 211,6 & 5,0 \\
\hline $\begin{array}{l}\text { Lápide } \\
\text { (Semidireto) }\end{array}$ & $54 \mathrm{kHz}$ & 5018,9 & 314,0 & 6,3 \\
\hline $\begin{array}{l}\text { Lápide Horizontal } \\
\text { (Indireto) }\end{array}$ & $54 \mathrm{kHz}$ & 3198,4 & 1178,2 & 36,8 \\
\hline $\begin{array}{l}\text { Lápide Vertical } \\
\text { (Indireto) }\end{array}$ & $54 \mathrm{kHz}$ & 2901,6 & 1093,2 & 37,7 \\
\hline
\end{tabular}

Nota-se que as velocidades médias obtidas com o transdutor de $54 \mathrm{kHz}$ apresentam menores valores do desvio padrão e consequentemente do coeficiente de variação, do que as obtidas com o transdutor de $150 \mathrm{kHz}$. Em relação aos tipos de transmissão, análises realizadas pelo método direto apresentam menores valores do coeficiente de variação do que as realizadas pelo método semidireto, que por usa vez apresenta menores valores do coeficiente de variação que as análises realizadas pelo método indireto. 
As velocidades obtidas nos pilares apresentaram-se levemente superiores às obtidas na estátua. Em relação aos pilares, as velocidades obtidas pelos métodos de transmissão direta, com os transdutores de $54 \mathrm{kHz}$ e $150 \mathrm{kHz}$, e semidireta, com o transdutor de $54 \mathrm{kHz}$, não apresentaram correlação que possibilitasse determinar qual pilar se apresenta menos ou mais homogêneo. A lápide, analisada pelo método de transmissão semidireta, possui velocidade média de $5019 \mathrm{~m} / \mathrm{s}$ e baixo coeficiente de variação, apresentando maior homogeneidade do que os pilares.

Foi avaliada a variação da cor da estátua Interrogação pela realização de medidas aleatórias por toda a escultura, compreendendo locais que visualmente não apresentavam processo de amarelamento, a partir da análise dos dados obtidos em três datas distintas (30/07/2012, 02/04/2012, 14/08/2012). Os valores da estatística descritiva aplicada aos parâmetros colorimétricos $L^{*}, a^{\star}, b^{\star}, C^{*}$ e $H^{\circ}$ estão apresentados na Tabela 18.

Tabela 18. Valores da estatística descritiva aplicada aos parâmetros colorimétricos $L^{\star}, a^{\star}, b^{\star}, C^{*} e H^{\circ}$, para a estátua Interrogação de Francisco Leopoldo e Silva.

\begin{tabular}{c|c|c|c|c|c|c}
\hline Local de Estudo & Estatística & $\mathbf{L}^{*}$ & $\mathbf{a}^{*}$ & $\mathbf{b}^{*}$ & $\mathbf{C}^{*}$ & $\mathbf{H}^{\circ}$ \\
\hline $\begin{array}{c}\text { Estátua (E1) } \\
(30 / 07 / 2010)\end{array}$ & Média & 65,81 & 1,39 & 9,42 & 9,53 & 82,15 \\
\hline & Desvio Padrão & 3,57 & 0,76 & 2,56 & 2,64 & 2,55 \\
\hline $\begin{array}{l}\text { Estátua (E2) } \\
(02 / 04 / 2012)\end{array}$ & Média & 63,69 & 2,42 & 13,10 & 13,33 & 79,61 \\
\hline & Desvio Padrão & 2,67 & 0,44 & 1,34 & 1,39 & 1,02 \\
\hline $\begin{array}{l}\text { Estátua (E3) } \\
(14 / 08 / 2012)\end{array}$ & Média & 67,90 & 2,01 & 12,44 & 12,61 & 81,07 \\
\hline & Desvio Padrão & 3,33 & 0,82 & 3,58 & 3,66 & 1,95 \\
\hline
\end{tabular}

Os valores das diferenças dos parâmetros colorimétricos $L^{*}, a^{*}, b^{*}$ e $C^{*}$ e diferença total de cor $(\Delta \mathrm{E})$, para comparações entre as diferentes datas de análise são apresentados na Tabela 19.

Tabela 19. Diferenças dos parâmetros colorimétricos $L^{*}, a^{*}, b^{*}$ e $C^{*}$ e diferença total de cor $(\Delta \mathrm{E})$, para comparæões entre as medidas realizadas em 30/07/2010 (TT1), 02/04/2012 (TT2) e 14/08/2012 (TT3), em todo o túmulo.

\begin{tabular}{c|c|c|c|c|c|}
$\begin{array}{c}\text { Locais de } \\
\text { Comparação }\end{array}$ & $\boldsymbol{\Delta} \mathbf{L}^{*}$ & $\boldsymbol{\Delta} \mathbf{a}^{*}$ & $\boldsymbol{\Delta} \mathbf{b}^{*}$ & $\boldsymbol{\Delta} \mathbf{C}^{*}$ & $\boldsymbol{\Delta E}$ \\
\hline E2-E1 & $-2,12$ & 1,03 & 3,68 & 3,80 & 4,37 \\
\hline E3-E1 & 2,09 & 0,62 & 3,02 & 3,08 & 3,72 \\
\hline E3-E2 & 4,21 & $-0,41$ & $-0,66$ & $-0,72$ & 4,28 \\
\hline
\end{tabular}


Os valores dos parâmetros colorimétricos $L^{*}, a^{*}, b^{*}, C^{*}$ e $H^{\circ}$ foram interpolados em diagramas de dispersão cartesianos $\left(C^{*}, L^{*}\right)$ e polares $\left(C^{*}, H^{\circ}\right)$ para visualização das variações desses índices em função das diferentes datas de análise (Figuras 118 e 119). O diagrama de dispersão dos valores do comprimento de onda na região da luz visível em função da quantidade de luz refletida está representado na Figura 120.

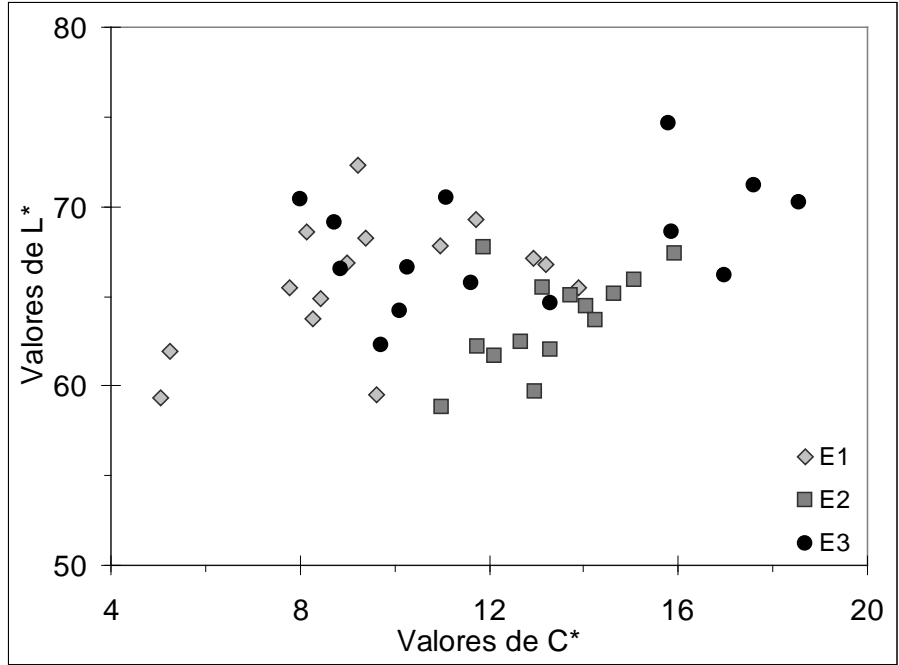

Figura 118. Diagrama de dispersão cartesiano para as variáveis $C^{*} e L^{*}$.

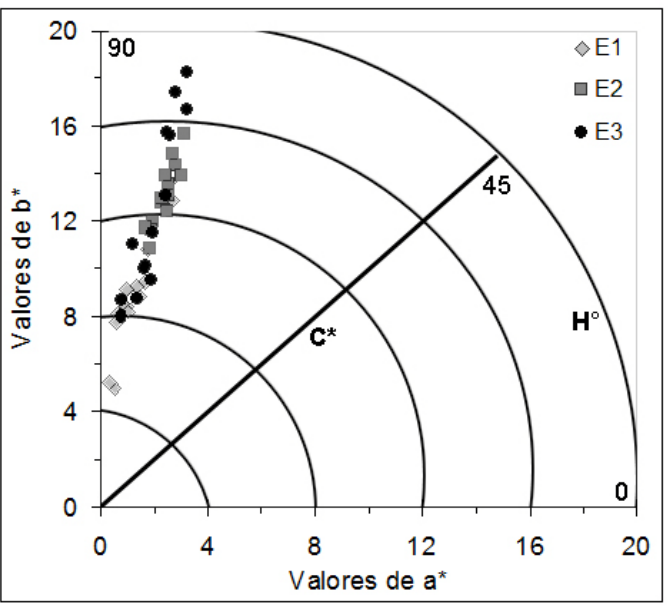

Figura 119. Diagrama de dispersão polar para as variáveis $\mathrm{C}^{*}$ e $\mathrm{H}^{\circ}$.

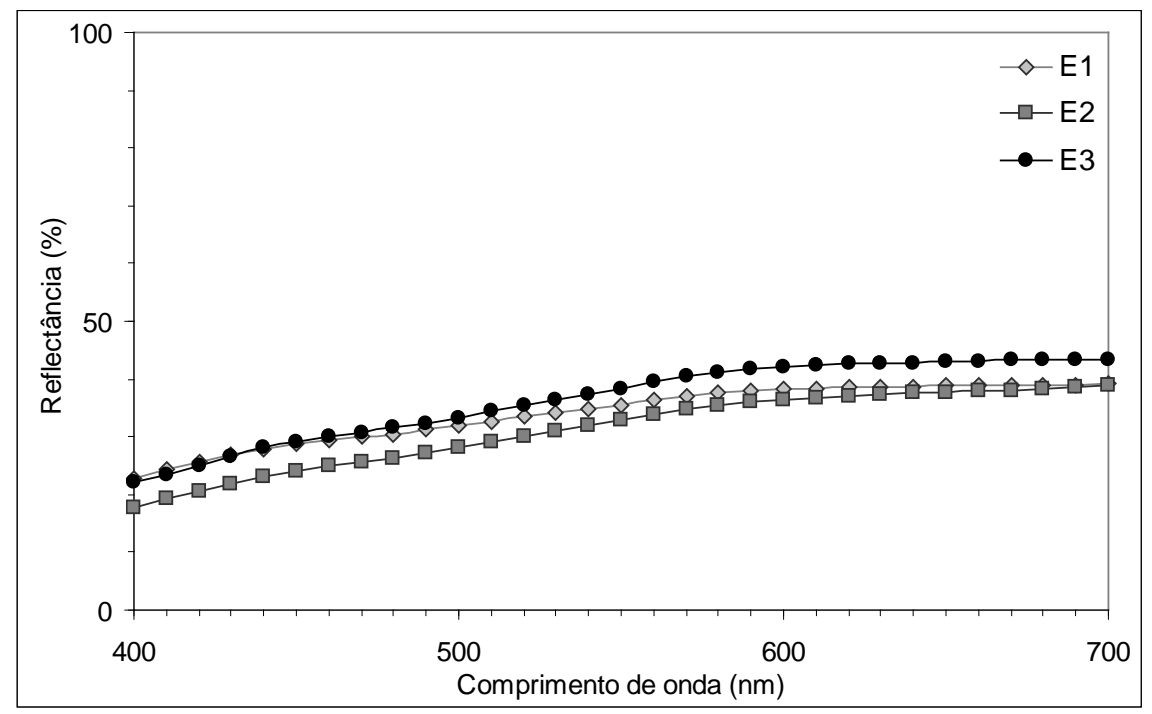

Figura 120. Gráfico de reflectância espectral.

Pela Tabela 18 e pela Figura 118 é possível afirmar que a luminosidade não apresentou modificação significativa nas distintas datas analisadas, notando-se apenas sutil escurecimento da primeira para a segunda análise e posteriormente leve clareamento. Da primeira para a segunda análise notou-se o leve avermelhamento e amarelamento da rocha, e posteriormente a diminuição da intensidade destas tonalidades. Apesar dos valores médios dos parâmetros $a^{*}$ e $b^{*}$ diminuírem da segunda para a terceira análise, pelas Figuras 118 e 119 nota-se o aumento do parâmetro $C^{*}$, indicando que apesar da média inferior, a 
análise da terceira data apresenta alguns valores máximos superiores aos obtidos anteriormente, indicando a tendência ao amarelamento da rocha. Os valores da diferença total de cor $\left(\Delta \mathrm{E}_{\mathrm{E} 2-\mathrm{E} 1}=4,37 ; \Delta \mathrm{E}_{\mathrm{E} 3-\mathrm{E} 1}=3,72 ; \Delta \mathrm{E}_{\mathrm{E} 3-\mathrm{E} 2}=4,28\right)$ mostram que a primeira e terceira análise apresentam menores diferenças entre os parâmetros colorimétricos do que a segunda e terceira análise. A Figura 120 mostra que as três análises apresentam semelhantes curvas de reflectância, variando apenas a intensidade da luz refletida. Nesse caso, a terceira análise apresenta os maiores valores de reflectância, enquanto a análise dois apresenta os menores valores.

A partir da interpretação de todos os dados para a estátua Interrogação pode-se concluir que:

- Os principais padrões de degradação existentes compreendem: alteração cromática, perda de partes e colonização biológica.

- A estátua e a estrutura que a comporta não possuem problemas evidentes relacionados a perda da homogeneidade da rocha, apresentando velocidades médias de propagação das ondas ultrassônicas correspondentes a uma rocha granítica sã.

- Os dados colorimétricos evidenciam o amarelamento da rocha com o tempo, e a provável limpeza realizada entre a segunda e terceira data de análise. Esta interpretação se deve ao aumento da luminosidade e sutil diminuição dos parâmetros $a^{*}$ e $b^{*}$, de E2 para E3, que pode indicar a retirada dos depósitos de fuligem, que proporcionam o escurecimento, assim como das concentrações de limonita, formada a partir da alteração dos sulfetos, que causa amarelamento e avermelhamento da rocha.

\subsubsection{Estátua Prece (1945) - Escultor Bruno Giorgi}

A estátua Prece do escultor Bruno Giorgi ornamenta o túmulo de Armando de Salles Oliveira. Nascido em São Paulo em 1887, formou-se em engenharia pela Escola Politécnica de São Paulo, atuando como governador da referida cidade na década de 1930. PertenceIhe o mérito de implantar dois marcos históricos da área educacional: a Universidade de São Paulo (USP) e o Instituto de Pesquisas Tecnológicas de São Paulo (IPT).

Em 1937, Salles Oliveira deixa o governo para se candidatar ao cargo de Presidente da República, na eleição marcada para janeiro de 1938. Devido à implantação do Estado 
Novo por Getúlio Vargas, a eleição não ocorre. Salles Oliveira fica exilado até 1945, quando retorna ao Brasil e falece em seguida.

A estátua Prece que ornamenta o seu túmulo foi encomendada pelo Governo do Estado de São Paulo para homenageá-lo, tratando-se de uma escultura abstrata que representa mãos emposição de prece. Comprometida com uma linguagem mais contemporânea, representa a simplificação dos elementos descritivos em proveito de volumes fortes, tratando-se do único exemplar de arte abstrata encontrado nos cemitérios de São Paulo (TFB, 2010).

Considerando a evolução do estado de conservação do túmulo (Figura 121 e 122), notou-se aumento da intensidade do amarelamento e escurecimento, principalmente da base. Observa-se em alguns locais o desenvolvimento de erosão diferencial.

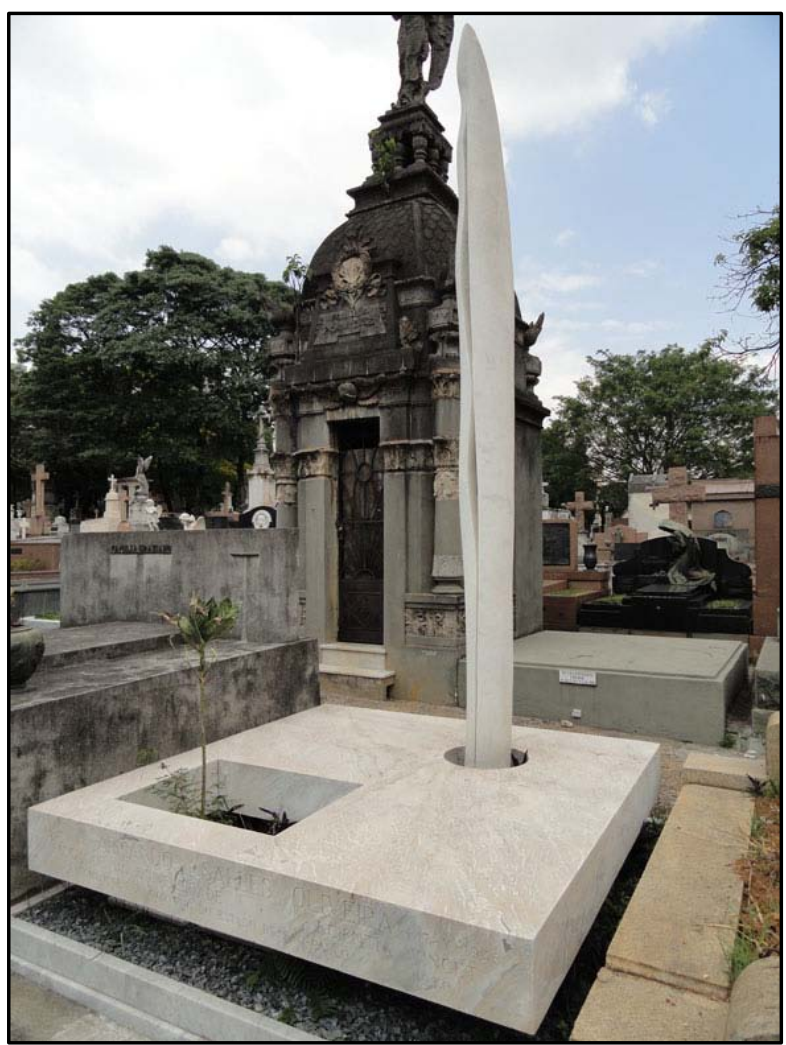

Figura 121. Estátua Prece fotografada no dia 28/10/2011, notando-se amarelamento da base de sustentação da escultura.

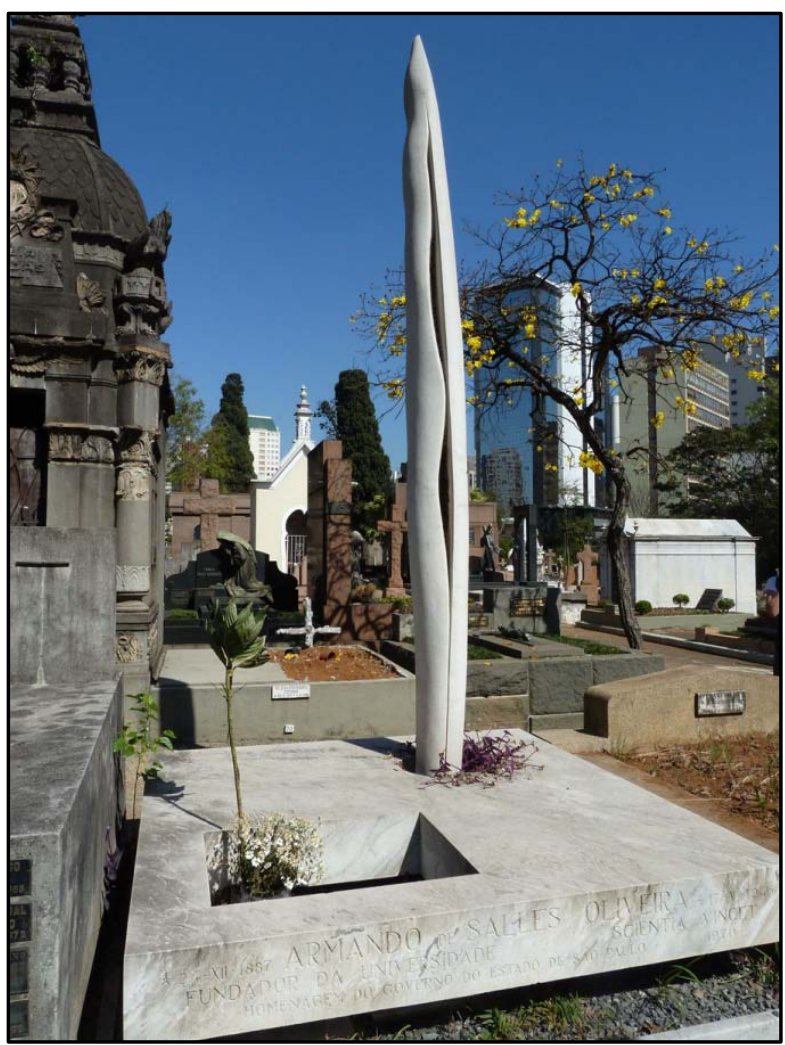

Figura 122. Estátua Prece fotografada no dia 14/08/2012, notando-se além do amarelamento, o escurecimento de alguns locais.

A avaliação da homogeneidade do mármore foi realizada com base nas velocidades das ondas ultrassônicas obtidas para ensaios realizados na parte central da estátua, com os pontos escolhidos aleatoriamente, conforme Figura 123. 


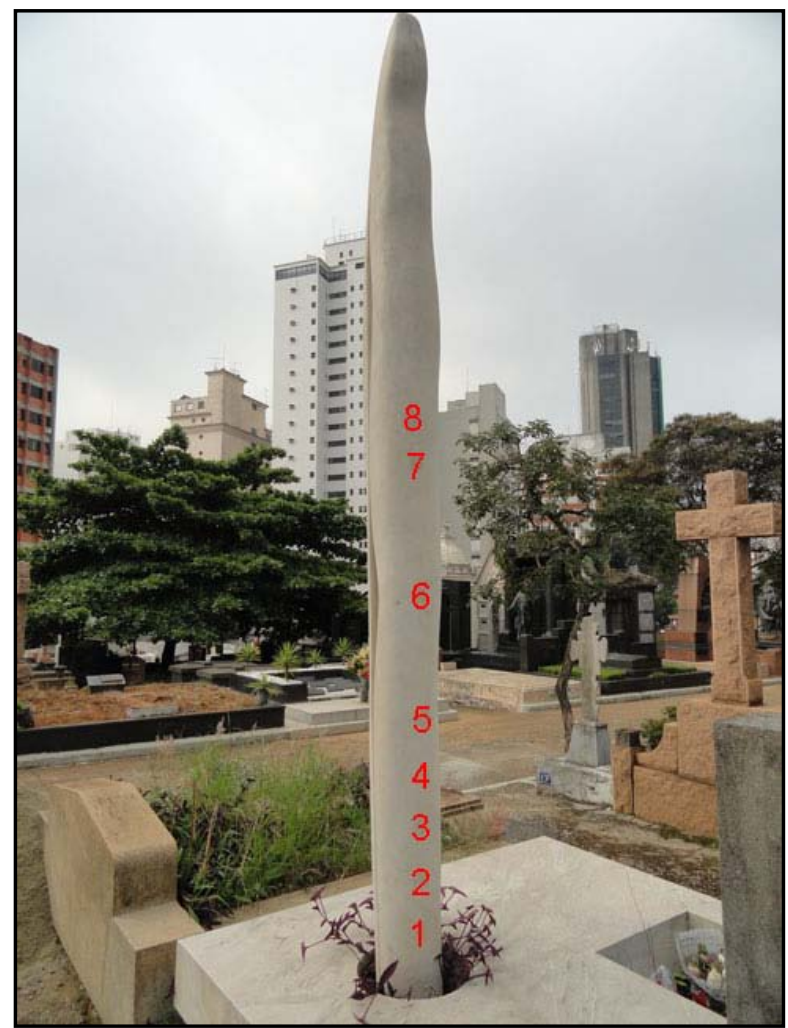

Figura 123. Localização dos locais de análise pela velocidade de propagação das ondas ultrassônicas.

Os valores das velocidades médias das ondas ultrassônicas, obtidos com os transdutores de $54 \mathrm{kHz}$ e $150 \mathrm{kHz}$ pelo método de transmissão direta, são apresentados na Tabela 20.

Tabela 20. Valores obtidos pelo método de transmissão direta.

\begin{tabular}{c|c|c|c}
\hline Transdutores & $\begin{array}{c}\text { Velocidade Média } \\
(\mathbf{m} / \mathbf{s})\end{array}$ & Desvio Padrão (m/s) & $\begin{array}{c}\text { Coeficiente de } \\
\text { Variação (\%) }\end{array}$ \\
\hline \hline $\mathbf{5 4} \mathbf{~ k H z}$ & 5217,5 & 214,6 & 4,1 \\
\hline $\mathbf{1 5 0} \mathbf{~ k H z}$ & 2774,1 & 1879,1 & 67,7 \\
\hline
\end{tabular}

Nota-se que os valores obtidos com o transdutor de $54 \mathrm{kHz}$ apresentaram menores valores para o desvio padrão e consequentemente para o coeficiente de variação se comparados aos obtidos com o transdutor de $150 \mathrm{kHz}$. Novamente a utilização do transdutor de $150 \mathrm{kHz}$ em campo não se mostrou prática para situação de estudo, pois os tempos de percurso da onda pela rocha apresentavam grande variação para cada pulso emitido pelo aparelho em um mesmo ponto estudado. Essa dificuldade está evidente nos valores do desvio padrão e coeficiente de variação obtidos, pois os locais estudados não apresentam qualquer indiciode alteração que justifique uma velocidade tão baixa. Desta forma, admite- 
se apenas a representatividade da velocidade obtida com o transdutor de $54 \mathrm{kHz}$, que é de $5217,5 \mathrm{~m} / \mathrm{s}$, condizente com o valor esperado para uma rocha sã.

O ponto 6, retratado na Figura 123, compreende uma cavidade com cerca de $10 \mathrm{~cm}$, que faz parte da estrutura da escultura. O local foi analisado e possui velocidade de propagação das ondas ultrassônicas de $831,8 \mathrm{~m} / \mathrm{s}$, com este valor descartado para o cálculo da média das velocidades para a estátua.

Foi avaliada a mudança da cor do túmulo, pela modificação dos parâmetros colorimétricos $L^{*}, a^{*}, b^{\star}, C^{*}$ e $H^{\circ}$, obtidos na estátua e na base de sustentação quadrada, em três datas distintas. Os valores da estatística descritiva aplicada aos locais analisados estão apresentados na Tabela 21.

Tabela 21. Os valores da estatística descritiva aplicada aos parâmetros colorimétricos $L^{\star}, a^{\star}, b^{\star}, C^{\star} e$ $\mathrm{H}^{\circ}$, em função do local estudado, para a Estátua Prece de Bruno Giorgi.

\begin{tabular}{|c|c|c|c|c|c|c}
\hline Local de Estudo & Estatística & $\mathbf{L}^{*}$ & $\mathbf{a}^{*}$ & $\mathbf{b}^{*}$ & $\mathbf{C}^{*}$ & $\mathbf{H}^{\circ}$ \\
\hline $\begin{array}{c}\text { Estátua (30/07/2010) } \\
\text { E1 }\end{array}$ & Média & 82,82 & 0,36 & 5,84 & 5,85 & 86,60 \\
\cline { 2 - 6 } & Desvio Padrão & 1,94 & 0,22 & 0,57 & 0,57 & 1,95 \\
\hline Base (30/07/2010) & Média & 78,21 & 2,26 & 11,30 & 11,53 & 78,80 \\
\hline B1 & Desvio Padrão & 2,50 & 0,47 & 1,49 & 1,54 & 1,43 \\
\hline $\begin{array}{c}\text { Estátua (02/04/2012) } \\
\text { E2 }\end{array}$ & Média & 79,98 & 0,78 & 7,00 & 7,04 & 83,81 \\
\hline Base (02/04/2012) & Desvio Padrão & 1,82 & 0,34 & 0,91 & 0,94 & 2,00 \\
\hline B2 & Média & 73,06 & 2,31 & 10,38 & 10,64 & 77,48 \\
\hline Estátua (14/08/2012) & Mesvio Padrão & 1,47 & 0,34 & 0,79 & 0,83 & 1,27 \\
\hline E3 & Desvio Padrão & 1,98 & 0,30 & 1,03 & 1,06 & 1,63 \\
\hline Base (14/08/2012) & Média & 66,42 & 2,30 & 9,71 & 9,98 & 76,69 \\
\hline B3 & Desvio Padrão & 2,52 & 0,25 & 0,54 & 0,57 & 0,98 \\
\hline
\end{tabular}

Os valores das diferenças dos parâmetros colorimétricos $L^{\star}, a^{*}, b^{\star}$ e $C^{\star}$ e diferença total de cor $(\Delta E)$, estão apresentados na Tabela 22. 
Tabela 22.Diferenças dos parâmetros colorimétricos $L^{\star}, a^{\star}, b^{\star}$ e $C^{\star}$ e diferença total de cor $(\Delta \mathrm{E})$, para comparções entre a estátua e sua base de sustentação, para medidas realizadas em datas similares ou distintas.

\begin{tabular}{c|c|c|c|c|c|}
\hline $\begin{array}{c}\text { Locais de } \\
\text { Comparação }\end{array}$ & $\mathbf{\Delta \mathbf { L } ^ { * }}$ & $\mathbf{\Delta} \mathbf{a}^{*}$ & $\mathbf{\Delta} \mathbf{b}^{*}$ & $\boldsymbol{\Delta} \mathbf{E}$ & $\boldsymbol{\Delta} \mathbf{C}^{*}$ \\
\hline E1-E2 & 2,84 & $-0,42$ & $-1,16$ & 3,10 & $-1,19$ \\
\hline E1-E3 & 3,19 & $-0,31$ & 0,06 & 3,21 & 0,03 \\
\hline E2-E3 & 0,35 & 0,11 & 1,22 & 1,27 & 1,22 \\
\hline B1-B2 & 5,15 & $-0,05$ & 0,92 & 5,23 & 0,89 \\
\hline B1-B3 & 11,79 & $-0,04$ & 1,59 & 11,90 & 1,55 \\
\hline B2-B3 & 6,64 & 0,01 & 0,67 & 6,67 & 0,66 \\
\hline E1-B1 & 4,61 & $-1,90$ & $-5,46$ & 7,39 & $-5,68$ \\
\hline E2-B2 & 6,92 & $-1,53$ & $-3,38$ & 7,85 & $-3,60$ \\
\hline E3-B3 & 13,21 & $-1,63$ & $-3,93$ & 13,88 & $-4,16$ \\
\hline
\end{tabular}

Os valores dos parâmetros colorimétricos $L^{*}, a^{*}, b^{*}, C^{*}$ e $H^{\circ}$ foram interpolados em diagramas de dispersão cartesianos $\left(C^{*}, L^{*}\right)$ e polares $\left(C^{*}, H^{\circ}\right)$ para visualização das variações desses índices em função dos diferentes locais e datas estudadas (Figuras 124 e 125). O diagrama de dispersão dos valores do comprimento de onda na região da luz visível em função da quantidade de luz refletida está representado na Figura 126.

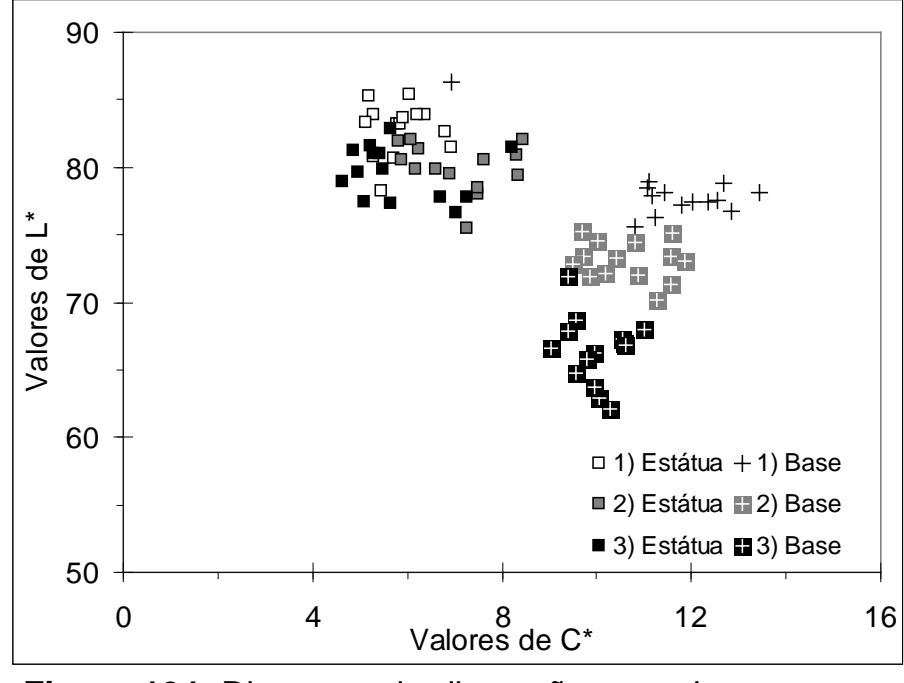

Figura 124. Diagrama de dispersão cartesiano para as variáveis $C^{*}$ e $L^{*}$.

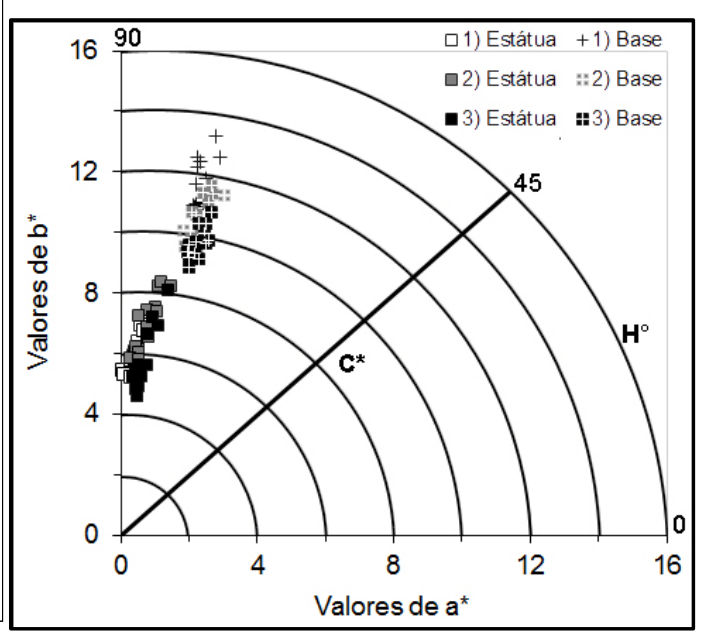

Figura 125. Diagrama de dispersão polar para as variáveis $\mathrm{C}^{*}$ e $\mathrm{H}^{\circ}$. 


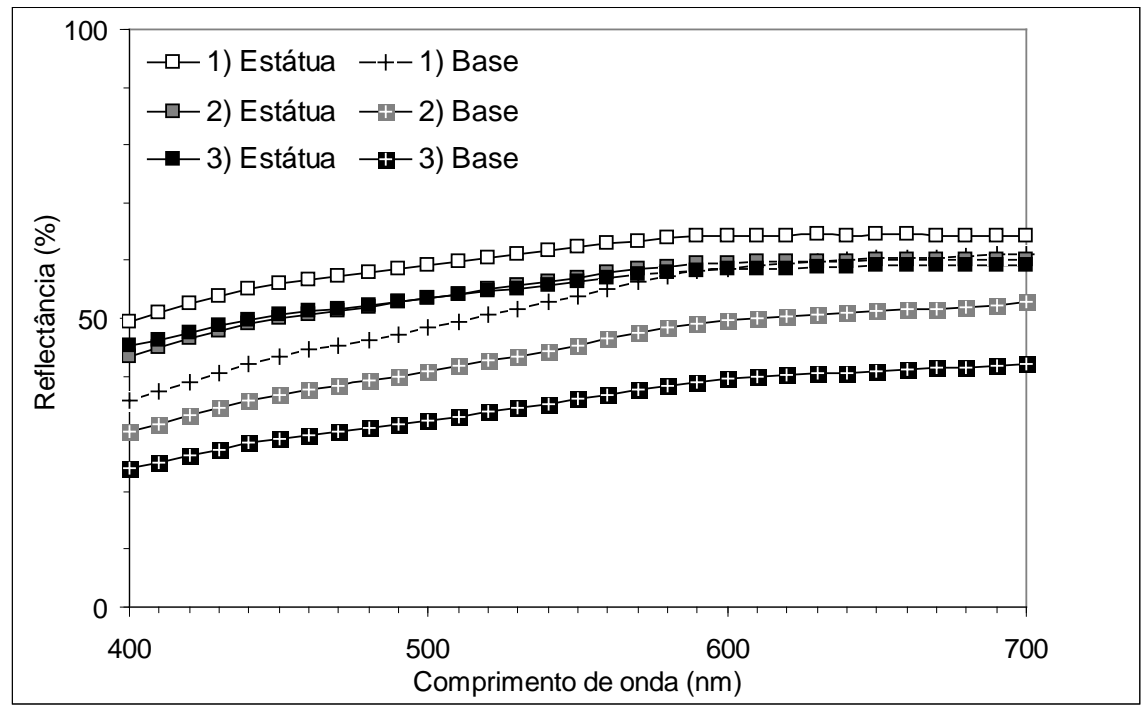

Figura 126. Gráfico de reflectância espectral.

Os valores de luminosidade obtidos para a estátua são superiores aos determinados para a base (Tabela 21 e Figura 124), o que indica que a estátua possui aspecto mais claro. Provavelmente isto se deve a maior facilidade de escoamento da água da chuva na estátua do que na base, que lixivia os depósitos de fuligem, que escurecem a superfície. Ambas as estruturas apresentam escurecimento com o tempo, o que pode retratar a ausência de limpeza do jazigo, e no caso da base, indicar a interação com a terra, existente na parte inferior do jazigo.

Considerando o parâmetro $C^{*}$, a estátua possui cor mais saturada do que a da base. Em relação à base de sustentação, nota-se sutil diminuição da saturação da cor com o tempo, relacionada à diminuição do índice $b^{*}$, o que indica perda da intensidade do amarelamento da rocha com o tempo. Em relação à cromaticidade $a^{\star}$, a estátua apresenta menor avermelhamento do que a base.

$\mathrm{O}$ estudo do ângulo de tinta $\mathrm{H}^{\circ}$, indica que a base de sustentação apresenta tonalidade com maior tendência ao amarelo, do que a estátua. Analisando os parâmetros em função da data de obtenção do dado, nota-se que com o tempo, ambas as estruturas adquirirem tonalidades mais avermelhadas, sendo que esta tendência foi identificada também, para a comparação estátua-base (E1-B1, E2-B2, E3-B3) em função da passagem do tempo.

Em relação à diferença total da cor $(\Delta \mathrm{E})$, em função do aumento do intervalo de tempo entre as análises, tanto a estátua como a base, apresentam aumento da diferença da cor, com a estátua apresentando menor taxa de variação do que a base de sustentação. Relacionando a diferença da cor entre a estátua e a base para uma mesma data de análise, nota-se o aumento da diferença da cor das estruturas com o tempo, com E3-B3 apresentando a máxima variação $(13,88)$. 
O gráfico de reflectância espectral (Figura 126) indica que a estátua apresenta maiores valores de refletância do que a base. Os maiores valores de reflectância, em ambas as estruturas, tendem a estabilização entre os comprimentos de onda de 600-700nm, correspondentes ao intervalo entre as cores laranja e vermelho.

A partir da interpretação de todos os dados para a estátua Prece, pode-se concluir que:

- A análise dos padrões de degradação da rocha indica que a estátua é menos afetada pelo amarelamento do que sua base de sustentação, que por sua vez, apresenta facilidade para o acúmulo de depósitos de fuligem e terra, que escurecem a superfície da estrutura.

- Em relação às velocidades médias de propagação das ondas ultrassônicas obtidas, a determinada com o uso do transdutor de $54 \mathrm{kHz}$ é mais representativa do que a obtida com o transdutor de $150 \mathrm{kHz}$, pois alude a uma rocha sã, como a caracterizada no jazigo.

- Os dados colorimétricos evidenciaram que a base de sustentação apresenta menor luminosidade, maior amarelamento e tendência ao avermelhamento do que a escultura. Em relação à diferença total da cor $(\Delta \mathrm{E})$, em função do aumento do intervalo de tempo entre as análises, tanto a estátua como a base, apresentam o aumento do valor do parâmetro, com a estátua apresentando menor taxa de variação do que a base de sustentação.

- O estado de conservação do jazigo é satisfatório. A rocha apresenta-se sã, ocorrendo apenas alteração cromática, principalmente escurecimento e amarelamento da superfície rochosa.

\subsubsection{Túmulo de Luisa Crema Marzorati (1922)}

Musicista chopiniana, Luisa Crema Marzorati nasceu na Itália e imigrou recém casada para o Brasil. Falecendo logo após a sua chegada, aos 26 anos, seu corpo foi embalsamado para que retornasse para a Itália com o marido, entretanto optou-se pelo seu sepultamento no Cemitério da Consolação.

A estrutura do túmulo, constituída por granito vermelho, sustenta uma estátua em mármore e ornamentação em bronze. A escultura (de autoria desconhecida) alude a uma lenda da mitologia grega, representando Eurídice sendo picada por uma serpente, no momento em que foge de Aristeu (Timpanaro, 2006). Consiste em uma jovem figura feminina com vestes muito finas e translúcidas, curvada para trás com as mãos sobre o 
peito, tentando libertar-se da morte, representada pela serpente envolta em sua perna. Próximo à base da escultura, antigamente existia uma placa de bronze com gravação de um poema em italiano em homenagem a falecida.

Considerando o estado de conservação do jazigo, o mesmo apresenta-se limpo e bem cuidado, notando-se sutil amarelamento do mármore e ainda, ausência da cabeça da cobra, que é representada na estátua. O grave problema de conservação encontrado é o relacionado aos furtos da ornamentação em bronze ${ }^{2}$, que causam a perda definitiva de elementos da história do jazigo.

A avaliação da homogeneidade do mármore foi realizada com base nas velocidades das ondas ultrassônicas obtidas para ensaios realizados na base de sustentação da estátua, conforme as Figuras 127 e 128.

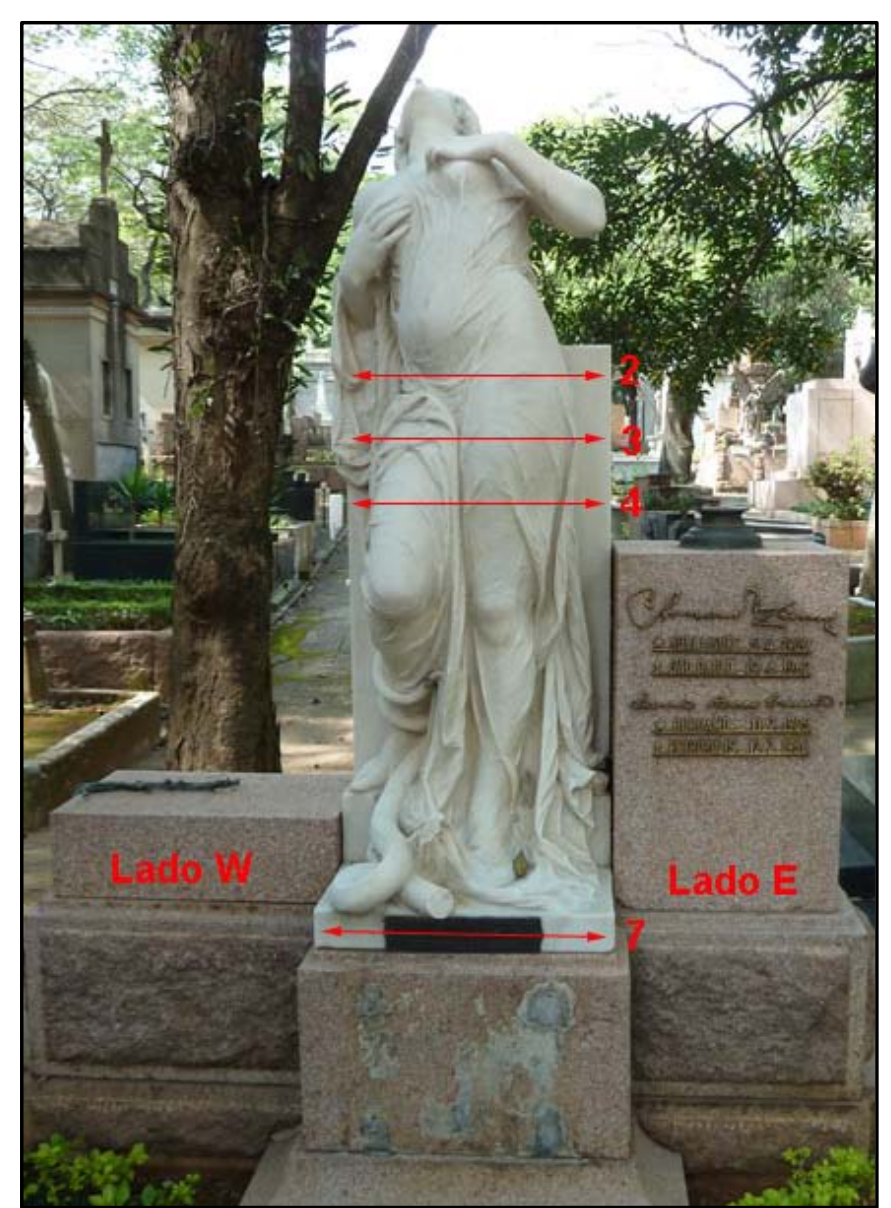

Figura 127. Locais onde foram realizadas as medidas pelo método de transmissão direta.

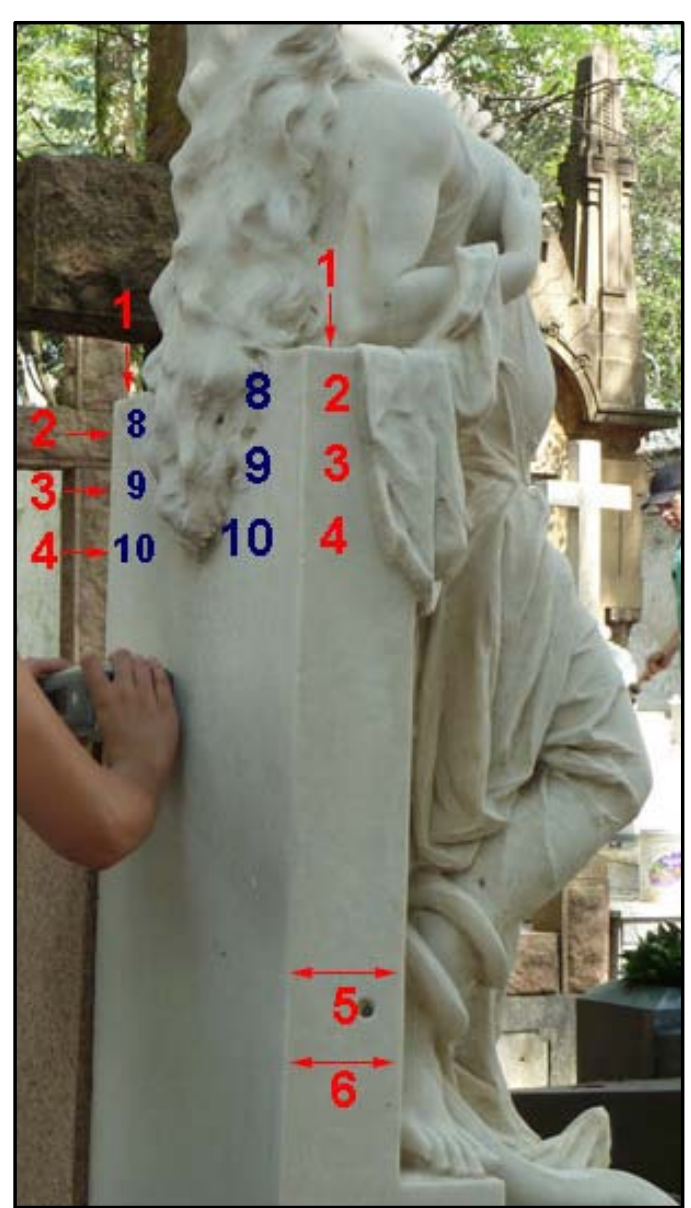

Figura 128. Locais onde foram realizadas as medidas pelo método de transmissão direta e semidireta.

\footnotetext{
${ }^{2}$ No capítulo 8.7. Vandalismo são mostradas fotografias que retratam a evolução dos furtos da ornamentação em bronze com o passar do tempo.
} 
Os valores das velocidades médias das ondas ultrassônicas, obtidos com os transdutores de $54 \mathrm{kHz}$ e $150 \mathrm{kHz}$, pelos métodos de transmissão direta e semidireta, são apresentados na Tabela 23.

Tabela 23.Valores obtidos para a avaliação realizada pela velocidade das ondas ultrassônicas.

\begin{tabular}{|c|c|c|c|c|}
\hline $\begin{array}{c}\text { Objeto I Método } \\
\text { de Transmissão }\end{array}$ & Transdutores & $\begin{array}{c}\text { Velocidade } \\
\text { Média (m/s) }\end{array}$ & $\begin{array}{c}\text { Desvio Padrão } \\
\text { (m/s) }\end{array}$ & $\begin{array}{c}\text { Coeficiente de } \\
\text { Variação (\%) }\end{array}$ \\
\hline $\begin{array}{c}\text { Estátua } \\
\text { (Direto) }\end{array}$ & $54 \mathrm{kHz}$ & 5164,1 & 181,1 & 3,5 \\
\hline $\begin{array}{c}\text { Estátua - Lado W } \\
\text { (Semidireto) }\end{array}$ & $54 \mathrm{kHz}$ & 5316,2 & 300,2 & 5,6 \\
\hline $\begin{array}{c}\text { Estátua - Lado W } \\
\text { (Semidireto) }\end{array}$ & $150 \mathrm{kHz}$ & 5595,0 & 152,2 & 2,7 \\
\hline $\begin{array}{c}\text { Estátua - Lado E } \\
\text { (Semidireto) }\end{array}$ & $54 \mathrm{kHz}$ & 4407,3 & 551,8 & 12,5 \\
\hline $\begin{array}{c}\text { Estátua - Lado E } \\
\text { (Semidireto) }\end{array}$ & $150 \mathrm{kHz}$ & 4226,9 & 718,1 & 17,0 \\
\hline
\end{tabular}

Os valores obtidos tanto com o transdutor de $54 \mathrm{kHz}$ como com o de $150 \mathrm{kHz}$ apresentam correspondência. As velocidades médiasobtidas pelo método de transmissão semidireta, utilizando ambos os transdutores, para o lado $E$ da base de apoio, são menores do que as calculadas para o lado $\mathrm{W}$, evidenciando a perda da homogeneidade da rocha nesta região. O valor da velocidade média obtida pelo método de transmissão direta é condizente com o esperado para uma rocha sã $(5164,1 \mathrm{~m} / \mathrm{s})$.

Foi avaliada a mudança da cor do túmulo, pela modificação dos parâmetros colorimétricos $L^{*}, a^{*}, b^{*}, C^{*} e H^{\circ}$, obtidos na estátua e na base de sustentação retangular, em duas datas distintas. Os valores da estatística descritiva aplicada aos locais analisados estão apresentados na Tabela 24. 
Tabela 24.Os valores da estatística descritiva aplicada aos parâmetros colorimétricos $L^{*}, a^{*}, b^{*}$, $\mathrm{C}^{\star}$ e $\mathrm{H}^{\circ}$, em função do local estudado.

\begin{tabular}{c|c|c|c|c|c|c}
\hline Local de Estudo & Estatística & $\mathbf{L}^{*}$ & $\mathbf{a}^{*}$ & $\mathbf{b}^{*}$ & $\mathbf{C}^{*}$ & $\mathbf{H}^{\circ}$ \\
\hline $\begin{array}{c}\text { Estátua - 30/07/2010 } \\
(\text { E1) }\end{array}$ & Média & 78,06 & 1,89 & 11,05 & 11,22 & 81,15 \\
\cline { 2 - 8 } & Desvio Padrão & 1,96 & 1,05 & 3,40 & 3,51 & 3,19 \\
\hline $\begin{array}{c}\text { Base - 30/07/2010 } \\
\text { (B1) }\end{array}$ & Média & 77,67 & 0,81 & 8,37 & 8,41 & 84,54 \\
\hline & Desvio Padrão & 1,02 & 0,25 & 1,02 & 1,03 & 1,27 \\
\hline $\begin{array}{c}\text { Estátua - 02/04/2012 } \\
\text { (E2) }\end{array}$ & Média & 79,08 & 1,87 & 10,92 & 11,09 & 80,97 \\
\hline \multirow{2}{*}{$\begin{array}{c}\text { Base - 02/04/2012 } \\
\text { (B2) }\end{array}$} & Desvio Padrão & 2,18 & 0,97 & 3,08 & 3,19 & 2,66 \\
\hline & Desvio Padrão & 1,09 & 0,32 & 1,16 & 1,18 & 1,84 \\
\hline
\end{tabular}

Os valores das diferenças dos parâmetros colorimétricos $L^{*}, a^{*}, b^{*}$ e $C^{*}$ e diferença total de cor $(\Delta \mathrm{E})$, estão apresentados na Tabela 25.

Tabela 25. Diferenças dos parâmetros colorimétricos $L^{*}, a^{*}, b^{\star}$ e $C^{\star}$ e diferença total de cor $(\Delta \mathrm{E})$, para compaçæ̃es entre a estátua e sua base retangular, para medidas realizadas em datas distintas.

\begin{tabular}{c|c|c|c|c|c}
\hline $\begin{array}{c}\text { Locais de } \\
\text { Comparação }\end{array}$ & $\boldsymbol{\Delta} \mathbf{L}^{*}$ & $\boldsymbol{\Delta} \mathbf{a}^{*}$ & $\boldsymbol{\Delta} \mathbf{b}^{*}$ & $\boldsymbol{\Delta E}$ & $\boldsymbol{\Delta} \mathbf{C}^{*}$ \\
\hline E1-B1 & 0,39 & 1,08 & 2,68 & 2,92 & 2,81 \\
\hline E2-B2 & 1,20 & 1,13 & 3,36 & 3,74 & 3,49 \\
\hline E1-E2 & $-1,02$ & 0,02 & 0,13 & 1,03 & 0,13 \\
\hline B1-B2 & $-0,21$ & 0,07 & 0,81 & 0,84 & 0,81 \\
\hline
\end{tabular}

Os valores dos parâmetros colorimétricos $L^{*}, a^{*}, b^{*}, C^{*}$ e $H^{\circ}$ foram interpolados em diagramas de dispersão cartesianos $\left(C^{*}, L^{*}\right)$ e polares $\left(C^{*}, H^{\circ}\right)$ para visualização das variações desses índices em função dos diferentes locais e datas estudadas (Figuras 129 e 130). O diagrama de dispersão dos valores do comprimento de onda na região da luz visível em função da quantidade de luz refletida está representado na Figura 131. 


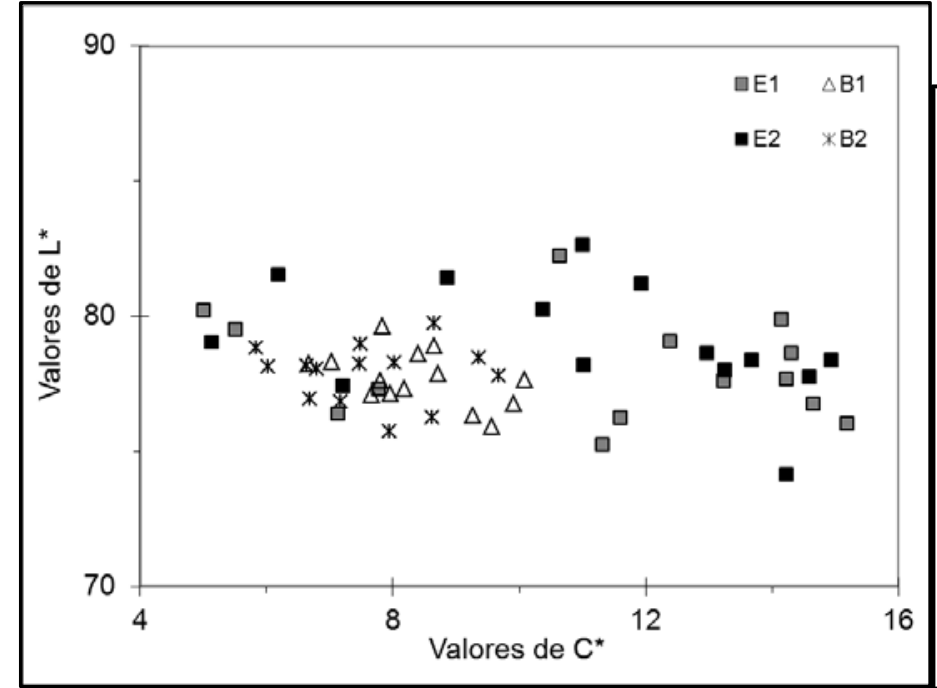

Figura 129. Diagrama de dispersão cartesiano para as variáveis $C^{*}$ e $L^{*}$.

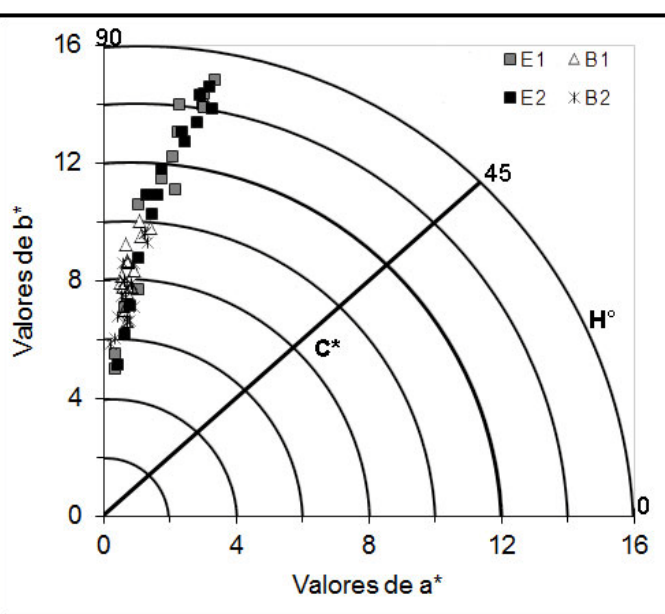

Figura 130. Diagrama de dispersão polar para as variáveis $\mathrm{C}^{\star}$ e $\mathrm{H}^{\circ}$.

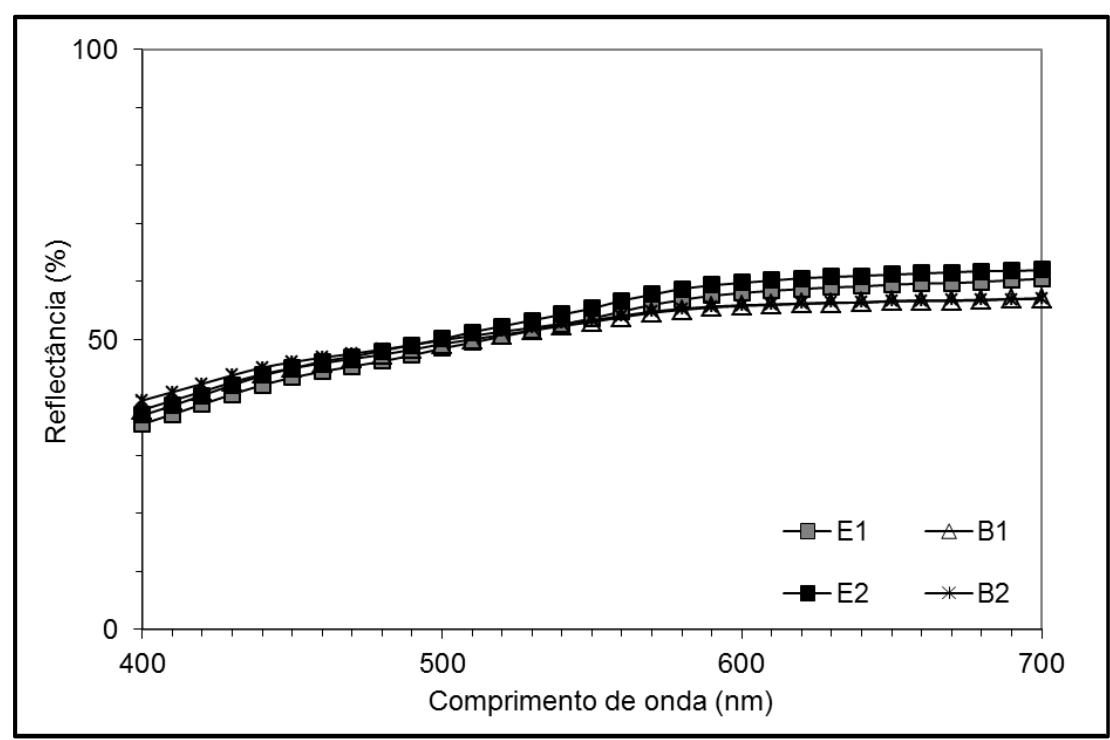

Figura 131. Gráfico de reflectância espectral.

Considerando a luminosidade L* (Tabelas 23 e 24 e Figura 129), tanto a estátua como a sua base de apoio possuem valores próximos, comsutil clareamento com o tempo. Em relação aos parâmetros $a^{*}, b^{*}$ e $C^{*}$, a estátua apresenta valores levemente superiores $\left(\Delta \mathrm{a}^{*}{ }_{\mathrm{E} 1-\mathrm{B} 1}=1,08 ; \Delta \mathrm{b}^{*}{ }_{\mathrm{E} 1-\mathrm{B} 1}=2,68 ; \Delta \mathrm{C}^{*}{ }_{\mathrm{E} 1-\mathrm{B} 1}=2,81 ; \Delta \mathrm{a}^{*}{ }_{\mathrm{E} 2-\mathrm{B} 2}=1,13 ; \Delta \mathrm{b}^{*}{ }_{\mathrm{E} 2-\mathrm{B} 2}=3,36 ; \Delta \mathrm{C}^{*}{ }_{\mathrm{E} 2-\mathrm{B} 2}=3,49\right)$, com sutil tendência de ambas as estruturas adquirirem cores menos saturadas e com diminuição do amarelamento e avermelhamento com o passar do tempo ( $\Delta \mathrm{a}^{*}{ }_{\mathrm{E} 1 \mathrm{E} \text {-E2 }}=0,02$; $\left.\Delta \mathrm{b}^{*}{ }_{\mathrm{E} 1-\mathrm{E} 2}=0,13 ; \Delta \mathrm{C}^{*}{ }_{\mathrm{E} 1-\mathrm{E} 2}=0,13 ; \Delta \mathrm{a}^{*}{ }_{\mathrm{B} 1-\mathrm{B} 2}=0,07 ; \Delta \mathrm{b}^{*}{ }_{\mathrm{B} 1-\mathrm{B} 2}=0,81 ; \Delta \mathrm{C}^{*}{ }_{\mathrm{B} 1-\mathrm{B} 2}=0,81\right)$.

Em relação àvariação total da cor, nota-se o aumento da diferença entre as cores da estátua e da base de apoio com o tempo $\left(\Delta \mathrm{E}_{\mathrm{E} 1-\mathrm{B} 1}=2,92\right.$ passa para $\left.\Delta \mathrm{E}_{\mathrm{E} 2-\mathrm{B} 2}=3,74\right)$. $\mathrm{A}$ variação do tempo promove modificação da cor com maior intensidade na estátua do que na base de apoio $\left(\Delta \mathrm{E}_{\mathrm{E} 1-\mathrm{E} 2}=1,03 ; \Delta \mathrm{E}_{\mathrm{B} 1-\mathrm{B} 2}=0,84\right)$. 
O gráfico de reflectância espectral (Figura 131) não indica variações significativas para a quantidade de luz refletida em função das estruturas e datas analisadas. Nota-se tendência a estabilização da curva de reflectância a partir de aproximadamente $600 \mathrm{~nm}$.

A partir da interpretação dos dados para o Túmulo de Luisa Crema Marzorati pode-se concluir que:

- O túmulo apresenta-se limpo e bem cuidado, aparentemente sem problemas relacionados à interação entre os materiais utilizados no jazigo (mármore, granito e bronze), ou ainda problemas intempéricos. No caso, o vandalismo constitui o dano mais representativo, seja pelo roubo da ornamentação em bronze ou pela provável quebra de parte da escultura de mármore.

- A velocidade de propagação das ondas ultrassônicas no mármore é aproximadamente $5164 \mathrm{~m} / \mathrm{s}$, o que alude a uma rocha sã. Aparentemente, a região $\mathrm{W}$ da base de apoio da escultura apresenta maior homogeneidade do que a região $\mathrm{E}$.

- Os parâmetros colorimétricos não apresentam variações significativas para avaliações realizadas entre a base de apoio e a estátua, para datas de análise semelhantes ou distintas. Apesar disto, a estátua apresenta valores levemente superiores à base para os parâmetros $a^{\star}, b^{\star}$ e $C^{*}$, indicando sutil tendência de ambas as estruturas adquirirem cores menos saturadas e com diminuição do amarelamento e avermelhamento com o passar do tempo.

\subsubsection{Túmulo da Marquesa de Santos (1867)}

Domitila de Castro Canto e Mello, a famosa Marquesa de Santos, é uma das figuras mais importantes da história do Brasil sepultadas no Cemitério da Consolação. Foi casada duas vezes, inicialmente com o alferes Felício Pinto Coelho de Mendonça, e após a morte do marido, com o brigadeiro Rafael Tobias de Aguiar, entretanto, ela é mais conhecida por ser a mais famosa das amantes de D. Pedro I.

Proveniente de família humilde, o seu envolvimento com o Imperador concede-Ihe dinheiro e títulos de nobreza, e também participação ativa na Corte Portuguesa. Após a rejeição do Imperador, voltou a morar em São Paulo, onde desenvolveu diversas obras sociais e culturais. 
Em relação ao Cemitério da Consolação, doou a quantia de dois contos de Réis para a construção da primeira capela do cemitério, demolida posteriormente. Faleceu em 3 de novembro de 1867, deixando em testamento a quantia de quatro contos de Réis, dinheiro utilizado para a compra de duas imagens religiosas importadas da Europa, uma de Nossa Senhora das Dores e outra de São João Evangelista, e também para a manutenção da capela do cemitério.

O seu jazigoé constituído por mármore, apresentando na sua parte anterior estilólitos, estruturas de pressão-dissolução comum em carbonatos. Segundo Valladares (1972), o marmorista J. M. P., residente na Rua D' Ajuda, 37 (Inscrição do endereço consta no jazigo) foi o construtor, artesão das lajes e da inscrição, porém não do anjo que tem características de peça importada.

Considerando o estado de conservação do jazigo, apesar de limpo e bem cuidado, conceitos da teoria da conservação nos mostra que o túmulo apresenta-se descaracterizado (Figura 132). Neste caso o principal mecanismo de degradação existente é a utilização de métodos inadequados de manutenção e conservação ${ }^{3}$, que promovem inicialmente a descaracterização da cor da rocha e subsequentemente outras formas de alteração que poderão causar a decomposição da rocha.

A avaliação da homogeneidade do mármore foi realizada com base nas velocidades das ondas ultrassônicas obtidas para ensaios realizados nos pilares de sustentação da cobertura que protege a escultura de um anjo. A indicação dos locais estudados está representada na Figura 133.

\footnotetext{
${ }^{3}$ Os métodos inadequados de manutenção e restauração utilizados no jazigo da Marquesa de Santos serão discutidos em detalhe no item 8.9. Métodos Inadequados de Conservação e Restauro.
} 


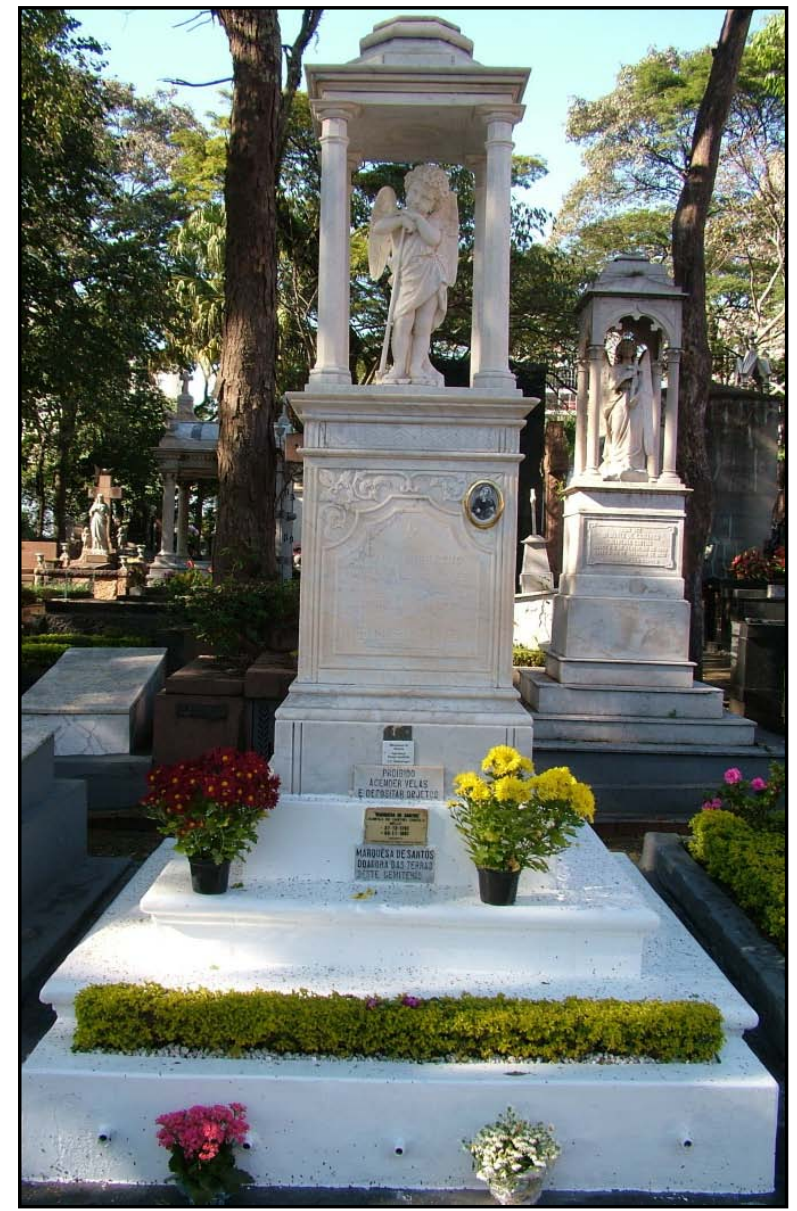

Figura 132. Jazigo da Marquesa de Santos, notar sua descaracterização pela pintura da base, com tinta látex, e pelo amarelamento do pedestal.

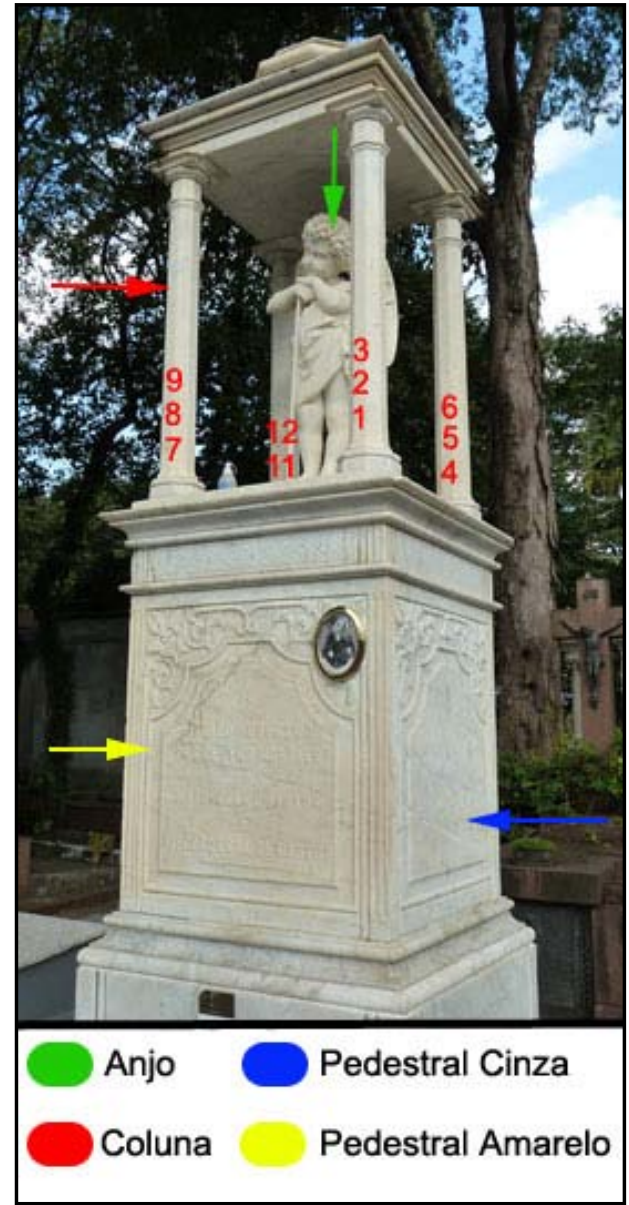

Figura 133. Localização dos locais estudados pela velocidade de propagação das ondas ultrassônicas (Pilares) e pela utilização do espectrofotômetro (Locais indicados pelas setas).

Os valores das velocidades médias de propagação das ondas ultrassônicas, obtidos com o transdutor de $150 \mathrm{kHz}$ pelo método de transmissão direta, são apresentados na Tabela 26. Neste caso não foi utilizado o transdutor de $54 \mathrm{kHz}$, pois seu diâmetro é superior à dimensão do local analisado.

Tabela 26. Valores obtidos pelo método de transmissão direta.

\begin{tabular}{|c|c|c|c|c|}
\hline $\begin{array}{c}\text { Objeto I Método de } \\
\text { Transmissão }\end{array}$ & Transdutores & $\begin{array}{c}\text { Velocidade } \\
\text { Média (m/s) }\end{array}$ & $\begin{array}{c}\text { Desvio Padrão } \\
\text { (m/s) }\end{array}$ & $\begin{array}{c}\text { Coeficiente de } \\
\text { Variação (\%) }\end{array}$ \\
\hline $\begin{array}{c}\text { Pilar P1 / } \\
\text { Direto }\end{array}$ & $150 \mathrm{kHz}$ & 3051,8 & 160,5 & 5,3 \\
\hline $\begin{array}{c}\text { Pilar P2 / } \\
\text { Direto }\end{array}$ & $150 \mathrm{kHz}$ & 3185,4 & 35,4 & 1,1 \\
\hline $\begin{array}{c}\text { Pilar P3 / } \\
\text { Direto }\end{array}$ & $150 \mathrm{kHz}$ & 2843,9 & 101,5 & 3,6 \\
\hline $\begin{array}{c}\text { Pilar P4 / } \\
\text { Direto }\end{array}$ & $150 \mathrm{kHz}$ & 2890,6 & 221,8 & 7,7 \\
\hline
\end{tabular}


As velocidades médias de propagação das ondas ultrassônicas mostram que a rocha que constitui os pilares P1 e P2 apresenta-se mais homogênea do que a rocha que constitui os pilares P3 e P4. Considerando os baixos valores do coeficiente de variação obtidos, pode-se afirmar que as velocidades calculadas são representativas e indicam a existência de um intemperismo incipiente das rochas que constituem os pilares.

Foi avaliada a mudança da cor do túmulo, pela modificação dos parâmetros colorimétricos $L^{*}, a^{*}, b^{*}, C^{*}$ e $\mathrm{H}^{\circ}$, obtidos em quatro locais distintos, conforme Figura 133. Os valores da estatística descritiva aplicada aos locais analisados estão apresentados na Tabela 27.

Tabela 27. Os valores da estatística descritiva aplicada aos parâmetros colorimétricos $L^{*}, a^{\star}, b^{*}, C^{*} e$ $\mathrm{H}^{\circ}$, em função do local estudado, para o Túmulo da Marquesa de Santos.

\begin{tabular}{c|c|c|c|c|c|c}
\hline Local de Estudo & Estatística & $\mathbf{L}^{*}$ & $\mathbf{a}^{*}$ & $\mathbf{b}^{*}$ & $\mathbf{C}^{*}$ & $\mathbf{H}^{\circ}$ \\
\hline $\begin{array}{c}\text { Estátua de Anjo } \\
(\mathrm{E})\end{array}$ & Média & 77,17 & 0,84 & 8,28 & 8,34 & 84,80 \\
\hline & Desvio Padrão & 4,63 & 0,64 & 2,15 & 2,21 & 2,48 \\
\hline $\begin{array}{c}\text { Colunas } \\
(\mathrm{C})\end{array}$ & Média & 78,00 & 1,92 & 11,97 & 12,14 & 81,51 \\
\hline & Desvio Padrão & 1,97 & 1,04 & 2,56 & 2,69 & 3,18 \\
\hline $\begin{array}{c}\text { Pedestal - Parte Cinza } \\
(\text { PC) }\end{array}$ & Média & 74,81 & $-0,14$ & 3,55 & 3,56 & 93,66 \\
\hline & Desvio Padrão & 2,65 & 0,18 & 1,25 & 1,24 & 4,59 \\
\hline $\begin{array}{c}\text { Pedestal - Parte Amarela } \\
\text { (PA) }\end{array}$ & Média & 78,97 & 3,85 & 16,16 & 16,63 & 76,71 \\
\cline { 2 - 7 } & Desvio Padrão & 1,54 & 0,78 & 1,21 & 1,33 & 1,97 \\
\hline
\end{tabular}

Os valores das diferenças dos parâmetros colorimétricos $L^{*}, a^{*}, b^{*}$ e $C^{*}$ e diferença total de cor $(\Delta E)$, estão apresentados na Tabela 28.

Tabela 28. Diferenças dos parâmetros colorimétricos $L^{*}, a^{\star}, b^{*}$ e $C^{\star}$ e diferença total de cor $(\Delta \mathrm{E})$, para comparễoes entre a estátua e sua base retangular, para medidas realizadas em datas distintas.

\begin{tabular}{|c|c|c|c|c|c|}
\hline $\begin{array}{c}\text { Locais de } \\
\text { Comparação }\end{array}$ & $\boldsymbol{\Delta L}^{*}$ & $\boldsymbol{\Delta} \mathbf{a}^{*}$ & $\boldsymbol{\Delta b}^{*}$ & $\boldsymbol{\Delta E}$ & $\boldsymbol{\Delta} \mathbf{C}^{*}$ \\
\hline E-C & $-0,83$ & $-1,08$ & $-3,69$ & 3,93 & $-3,8$ \\
\hline E-PC & 2,36 & 0,98 & 4,73 & 5,38 & 4,78 \\
\hline E-PA & $-1,80$ & $-3,01$ & $-7,88$ & 8,63 & $-8,29$ \\
\hline C-PC & 3,19 & 2,06 & 8,42 & 9,24 & 8,58 \\
\hline C-PA & $-0,97$ & $-1,93$ & $-4,19$ & 4,71 & $-4,49$ \\
\hline PC-PA & $-4,16$ & $-3,99$ & $-12,61$ & 13,86 & $-13,07$ \\
\hline
\end{tabular}


Os valores dos parâmetros colorimétricos $L^{*}, a^{*}, b^{*}, C^{*}$ e $H^{\circ}$ foram interpolados em diagramas de dispersão cartesianos $\left(C^{*}, L^{*}\right)$ e polares $\left(C^{*}, H^{\circ}\right)$ para visualização das variações desses índices em função dos diferentes locais estudados (Figuras 134 e 135). O diagrama de dispersão dos valores do comprimento de onda na região da luz visível em função da quantidade de luz refletida está representado na Figura 136.

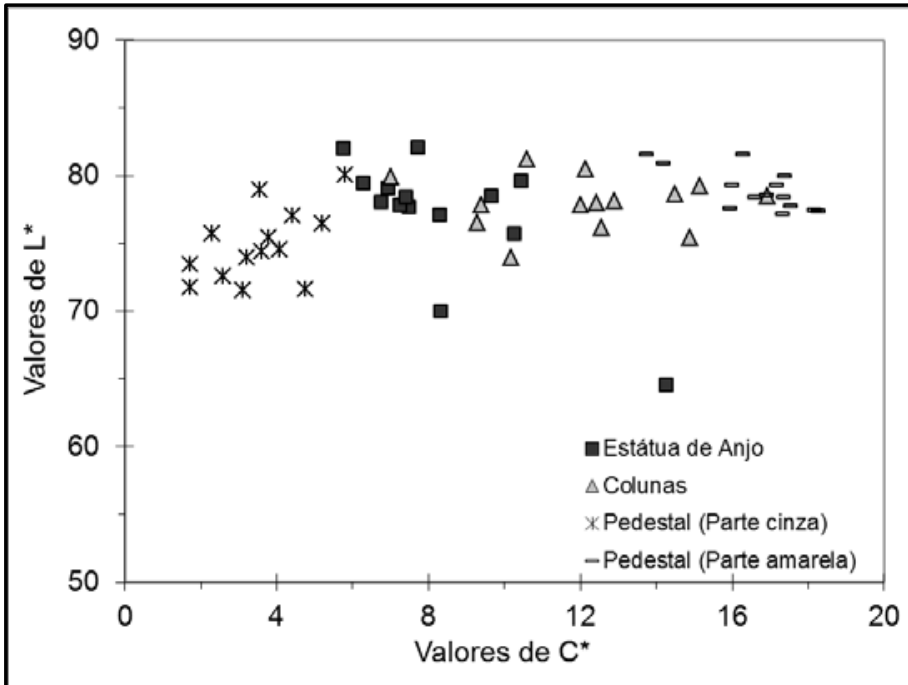

Figura 134. Diagrama de dispersão cartesiano para as variáveis $C^{*}$ e $L^{*}$.

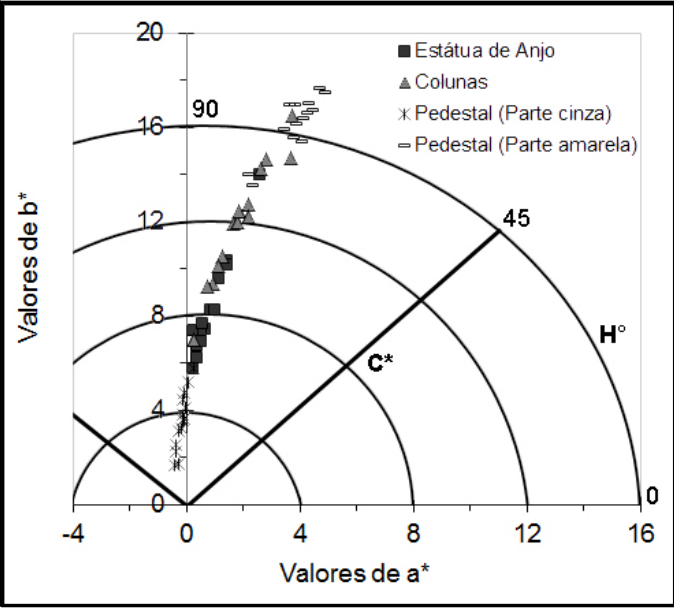

Figura 135. Diagrama de dispersão polar para as variáveis $\mathrm{C}^{*} \mathrm{e} \mathrm{H}^{\circ}$.

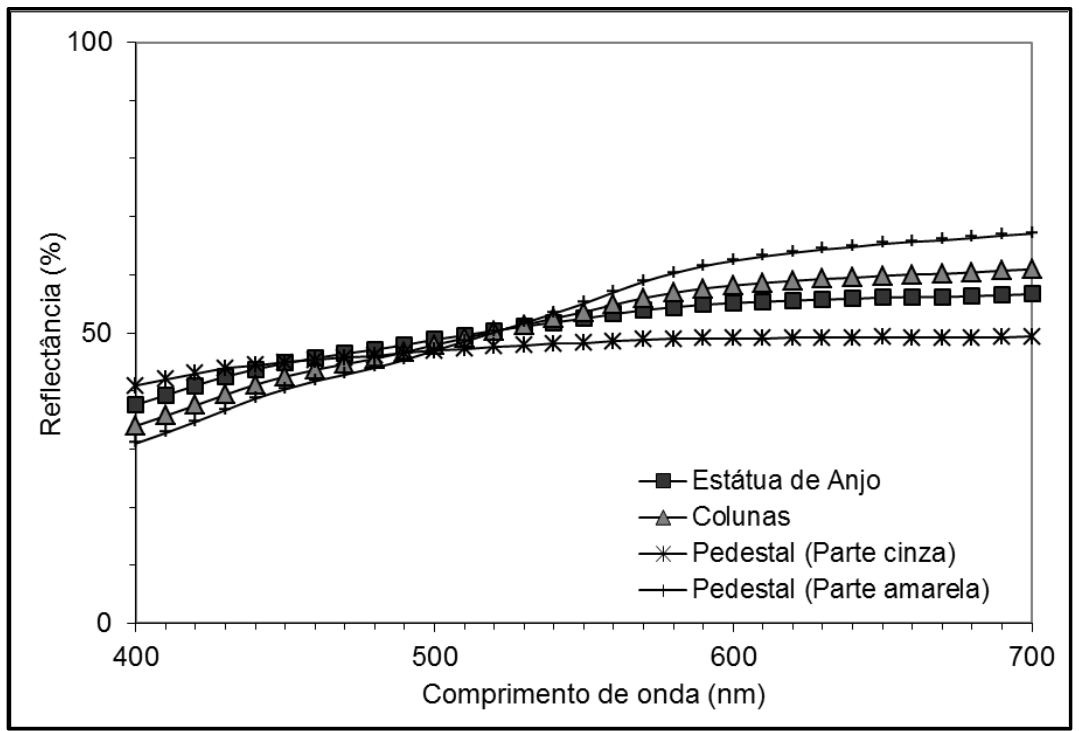

Figura 136. Gráfico de reflectância espectral.

Considerando a luminosidade L* (Tabelas 27 e 28e Figura 134), a estátua de anjo, as colunas e o pedestal amarelo, apresentam valores próximos, indicando clareamento maior do que o pedestal cinza, que se apresenta mais escurecido. Em relação aos parâmetros $a^{*}$, $b^{*}, C^{*}$ e $H^{\circ}$, nota-se através da Figura 135, tendência ao amarelamento e 
avermelhamentoda rocha, além do aumento da saturação da sua cor, em função dos diferentes locais analisados.

Comparando-se o pedestal cinza com o pedestal amarelo no quesito luminosidade, nota-se variação máxima para este parâmetro $\left(\Delta L^{*}{ }_{\mathrm{PC}-\mathrm{PA}}=-4,16\right)$ no túmulo em análise. Considerando que ambos os locais também possuem a variação máxima de cor $\left(\Delta \mathrm{E}_{\mathrm{PC}-\mathrm{PA}}=\right.$ 13,86), pode-se concluir que as constantes limpezas pelas quais o túmulo é submetido, em várias ocasiões utilizando-se produtos químicos (nota-se que o pedestal cinza apresenta-se mais escuro e menos amarelo e vermelho do que o pedestal amarelo), é o mecanismo de degradação envolvido no amarelamento e avermelhamento progressivo da rocha.

O gráfico de reflectância espectral (Figura 136) também indica o amarelamento e avermelhamento progressivo da rocha, com a estabilização da curva e aumento dos valores de reflectância, coincidindo com o aumento dos comprimentos de onda (tendendo a região do amarelo, laranja e vermelho), conforme aumenta os valores dos parâmetros colorimétricos $\mathrm{a}^{\star}, \mathrm{b}^{*}, \mathrm{C}^{*}$ e diminuição do parâmetro $\mathrm{H}^{\circ}$.

A partir da interpretação dos dados para o Túmulo da Marquesa de Santos pode-se concluir que:

- O túmulo apesar de apresenta-se limpo e aparentemente bem cuidado, sofreu descaracterização pela modificação da cor da rocha e por mudanças estéticas realizadas no jazigo.

- A velocidade de propagação das ondas ultrassônicas nos pilares em mármore é variável entre $2843,9-3185,4 \mathrm{~m} / \mathrm{s}$, mostrando a perda de homogeneidade da rocha.

- Os parâmetros colorimétricos retratam a tendência da rocha ao amarelamento e avermelhamento em função dos diferentes locais analisados. Esta tendência é associada às constantes limpezas, em várias ocasiões utilizando-se produtos químicos, as quais o túmulo é submetido, constituindo o mecanismo de degradação mais atuante no jazigo. 


\section{MECANISMOS DE DEGRADAÇÃO}

A identificação dos mecanismos de degradação é uma etapa importante para determinarmedidas de conservaçãoadequadas. A partir do mapeamento dos padrões de deterioração da rocha, informação integrada com os valores da velocidade de propagação das ondas ultrassônicas, dos parâmetros colorimétricos e das curvas de reflectância, foi possível identificar os principais mecanismos de degradação existentes no Cemitério da Consolação, que compreendem: natureza litológica, interação de materiais, poluição atmosférica, colonização biológica, condições climáticas, características arquitetônicas, vandalismo, falta de gerenciamento e métodos inadequados de conservação e restauro.

\subsection{NATUREZA LITOLÓGICA}

Alguns tipos de rocha são mais susceptíveis ao intemperismo do que outros, o que pode estar associado as suas características petrográficas, a alguma condição adquirida na pedreira ou no processo de beneficiamento pelo qual a rocha passou. Nesse caso, a natureza litológica é o principal condicionante para a degradação da rocha, com outros agentes agindo de maneira secundária. No Cemitério da Consolação foram identificadas duas condições importantes que facilitam a degradação da rocha, o condicionante mineralógico e a alteração herdada, englobando os seguintes casos:

- Alguns tipos de granito vermelho apresentam quantidades significativas de minerais opacos, estes apresentamsusceptibilidade à alteração, o que promove a geração de inúmeras cavidades na rocha (Figura 137). A princípio, o orifício gerado não oferece risco ao monumento, entretanto dependendo da disposição da estrutura que comporta a cavidade, estapode vir a acumular água ematéria orgânica, propiciando a proliferação de colonização biológica. Algumas cavidades foram preenchidas por argamassa, provavelmente com a finalidade de diminuir a descaracterização da rocha, entretanto notando-se a coloração avermelhada do material e sabendo que o mineral alterado possuía tonalidade próxima ao preto, pode-se afirma que não foi realizado qualquer estudo para determinar o que estava causando os orifícios e muito menos como será a interação do material aplicado com a rocha e sua deterioração com o tempo.

- A calcita, principal mineral constituinte dos mármores, apresenta coeficientes de expansão termal bastante distintos nas diferentes direções cristalográficas. Essa 
anisotropia dos cristais de calcita é a grande responsável pelo aumento da porosidade nos mármores (Luque et al., 2011). O fissuramento gerado facilita posteriormente o ataque químico da rocha.

- Os minerais apresentam diferentes suscetibilidades ao intemperismo químico, o que promove o aparecimento da erosão diferencial. No caso da Figura 138, trata-se de um calcário fossilífero, que diferentemente do Lioz, que é composto predominantemente por gastrópodes e possui erosão diferencial onde o fóssil fica preservado e a matriz é dissolvida, essa rocha apresenta dissolução dos fósseis e preservação da matriz. Foi identificado que os fósseis predominantes nesse litotipo são corais, apresentando-se quebrados e dispostos em várias direções em relação aos seus eixos de simetria. Corais vivem em ambiente de água quente e rasa, sua disposição irregular e seu aspecto quebrado indicam um ambiente com alta energia e retrabalhamento. Nesse caso a rocha pode ser classificada como tempestito, sendo que a matriz provavelmente não é composta predominantemente por carbonato, possuindo quantidades significativas de quartzo. Por esse motivo a matriz apresenta-se melhor preservada que os fósseis, que são compostos por carbonato.

- Túmulos construídos com o monzonito chamado comercialmente de Preto Bragança apresentam descamação da sua superfície (Figura 139). Certamente esse padrão de deterioração estárelacionadoa geração de pressão interna, devido à percolação de água, e sua posterior evaporação (influenciada pela insolação), nos microfissuramentos identificados, relacionados ao corte e polimento dessa rocha ornamental.

- Dois túmulos constituídos pelo Granito Itaquera apresentam processos de deterioração muito intensos. Apesar de serem considerados um dos mais antigos, ou seja, com maior tempo de exposição no cemitério, cerca de vinte anos a mais que a estátua Solitudo de Francisco Leopoldo e Silva, por exemplo, isso nãojustificaas formas de degradação encontradas (Figura 140). Desta maneira admite-se que as rochas utilizadas na confecção dos túmulos já deveriam apresentar processos de deterioração no local da sua extração, ou seja, as formas de deterioração que vemos hoje constituem alterações herdadas. 


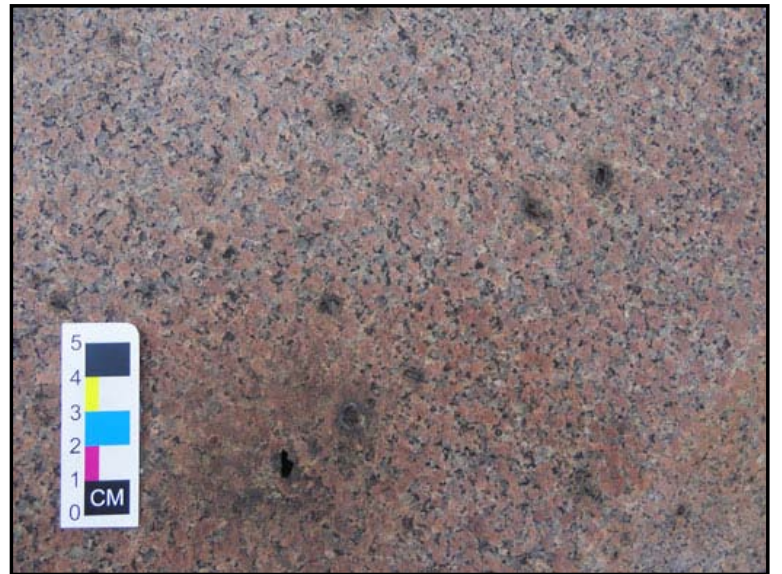

Figura 137. Cavidades geradas pela alteração de minerais opacos.

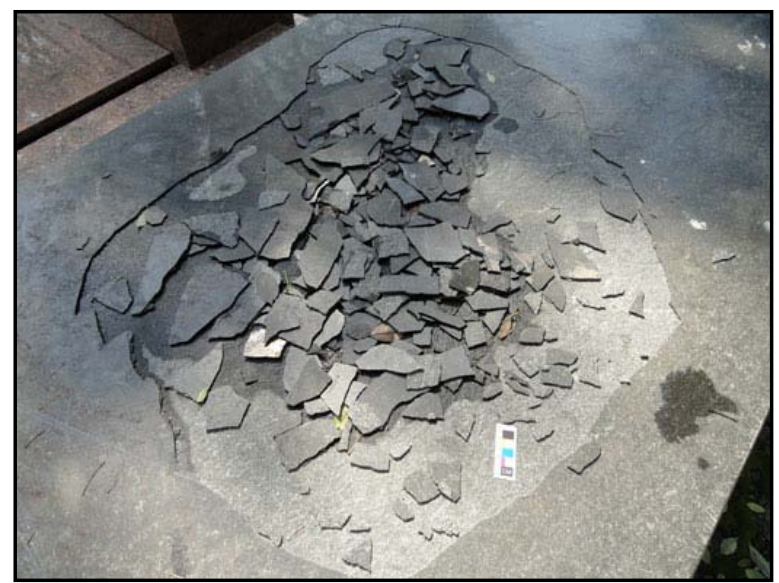

Figura 139. Escamação do Granito Preto Bragança.

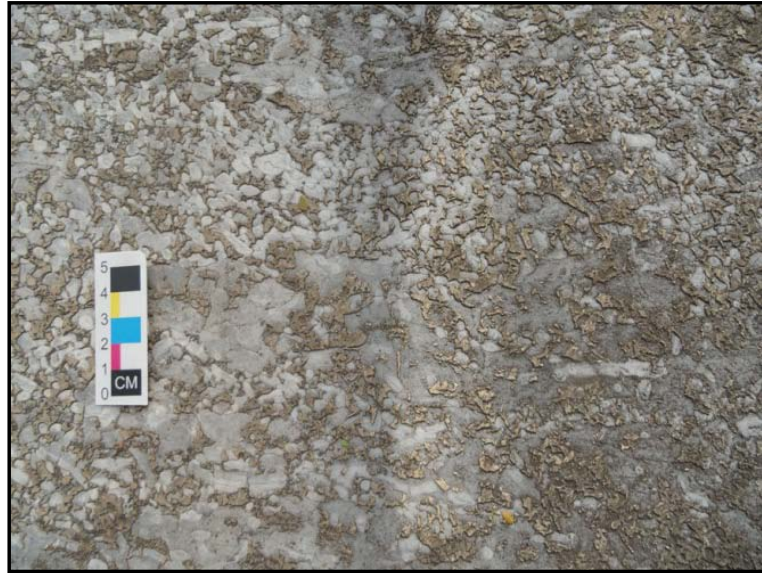

Figura 138. Erosão diferencial, com preservação da matriz e dissolução do conteúdo fossilífero.

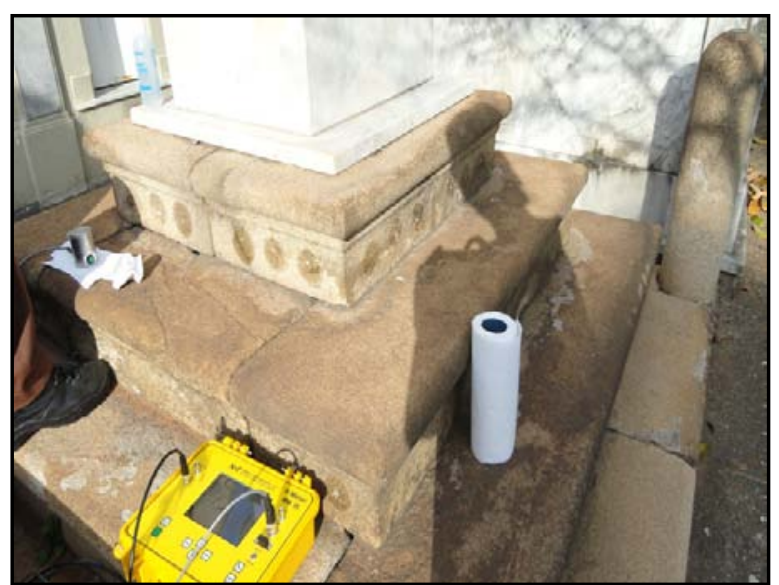

Figura 140. Forma de alteração intensa no Granito Itaquera.

\subsection{INTERAÇÃO DE MATERIAIS}

A interação entre os diferentes materiais existentes na estrutura do jazigo pode promover o aparecimento de determinadas formas de deterioração. Como visto nas Figuras 25 e 26, a oxidação de componentes metálicos internos, provoca o colapso de parte da estrutura do jazigo.

No caso daornamentação em bronze, cobre ou em outro tipo de metal, a sua alteração gera pátinas, que quando lixiviadas e precipitadas, promovema alteração cromática da rocha que compõe o túmulo. Coloração avermelhada indica a oxidação de componentes em ferro (Figura 141), enquanto a coloração esverdeada indica a de componentes em cobre ou bronze (Figuras 142 e 143). 


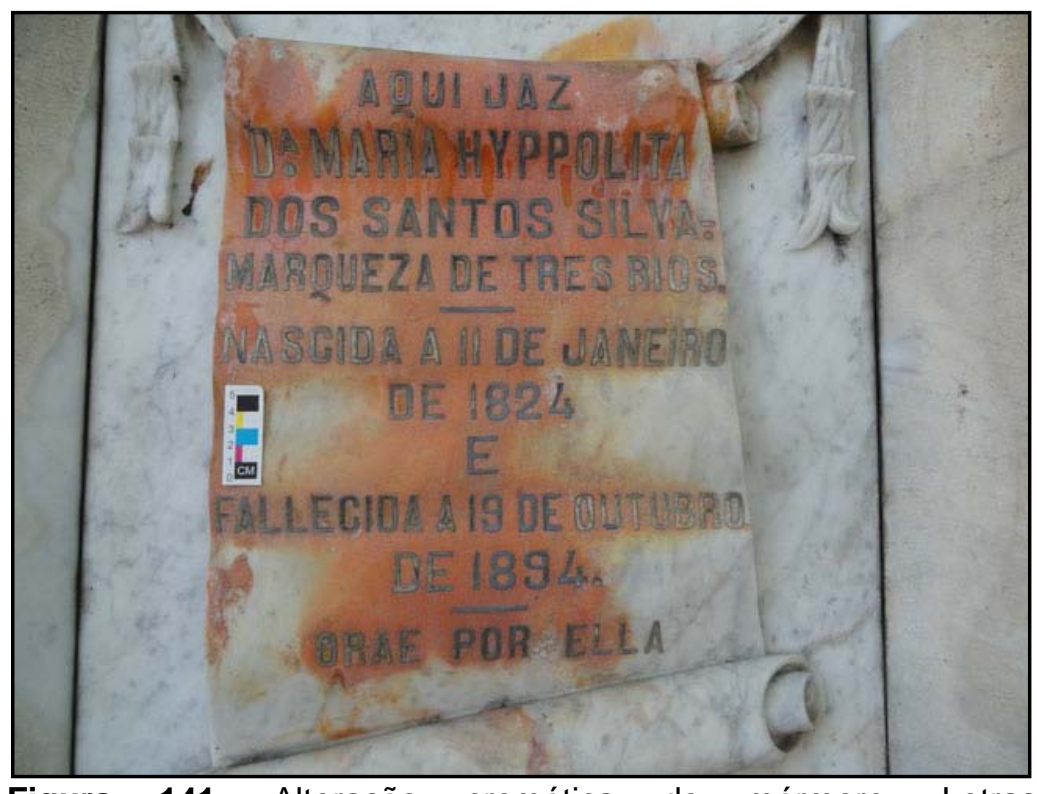

Figura 141. Alteração cromática do mármore. Letras provavelmente confeccionadas em ferro.

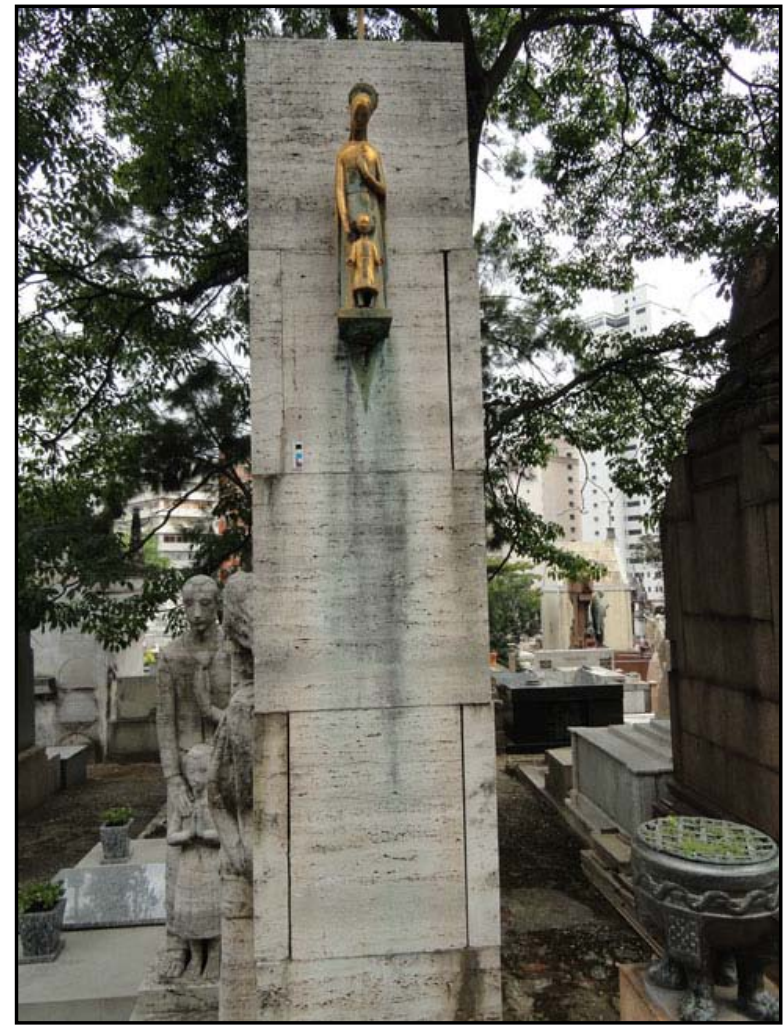

Figura 142. Alteração cromática do travertino. Estátua provavelmente confeccionada em cobre ou bronze.

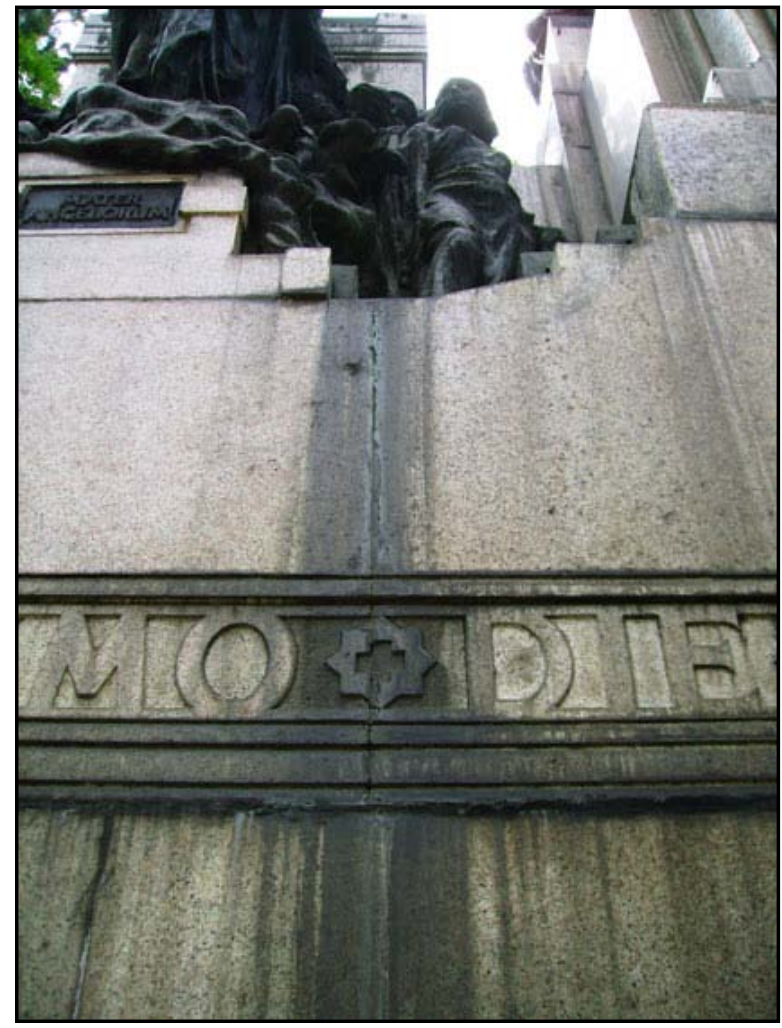

Figura 143. Alteração cromática do granito. Estátuas provavelmente confeccionadas em cobre ou bronze. 


\subsection{POLUIÇÃO ATMOSFÉRICA}

Análises da qualidade do ar da região metropolitana de São Paulo mostram que os níveis de poluição ultrapassam, várias vezes ao ano, as concentrações aceitáveis para determinados grupos de poluentes (material particulado, fumaça, ozônio, dióxido de nitrogênio, monóxido de carbono, dióxido de enxofre, etc). A concentração dos poluentes na atmosfera é influenciada pela distribuição e intensidade da sua emissão, pela topografia e pelas condições meteorológicas reinantes. O Estado de São Paulo possui variações sazonais significativas das condições atmosféricas, distinguindo-se nitidamente as condições climáticas de inverno e verão. As concentrações mais altas dos poluentes, à exceção do ozônio, ocorrem, via de regra, no período compreendido entre os meses de maio a setembro, devido à maior ocorrência de inversões térmicas em baixos níveis, alta porcentagem de calmaria, ventos fracos e baixos índices pluviométricos (CETESB, 2012).

O Cemitério da Consolação está localizado em uma rua com intenso fluxo de automóveis. Segundo Nord e Holenyi (1999), há correlação positiva entre tráfego de automóveis e danos a monumentos constituídos por rocha carbonática; sujidade nas construções e conteúdo de enxofre na superfície das rochas. Estes autorespontuam também que o conteúdo de $\mathrm{SO}_{2}$ e $\mathrm{SO}_{3}$ no ar são recursos importantes na aceleraçãoda sulfatação da calcita e portantona deterioração dos mármores. Begonha (1997) afirma que a presença do ferro ou de outros metais de transição funciona como catalizadores da reação de oxidação do dióxido de enxofre.

No Cemitério da Consolação, a poluição atmosférica é inferida como principal mecanismo de deterioração nos seguintes casos:

- Enegrecimento dos túmulos pela deposição, via seco, de material particulado proveniente da queima dos combustíveis fósseis (Figura 144);

- Suavização de estátuas e lápides devido à dissolução do mármore pela chuva ácida (Figura 145 e 146). As reações químicas que exemplificam esse processo são a acidificação da água da chuva (Reação 1) e a dissolução da calcita pelo ácido carbônico (Reação 2).

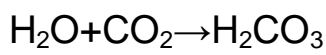

(Reação 1)

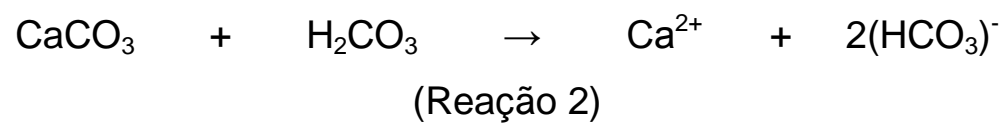


- $\quad$ Fissuramento e posteriormente desagregação granular dos mármores (Figura 147), devido à geração da gipsita, formada pela reação entre componentes que possuem enxofre $\left(\mathrm{SO}_{2}, \mathrm{SO}_{3}, \mathrm{H}_{2} \mathrm{SO}_{4}\right)$, água (líquida ou vapor) ea calcita. Como a gipsita possui um volume maior que a matriz carbonática, acaba por fraturar a rocha. Há duas hipóteses para a formação da gipsita (Dionísio et al., 2004), a primeira é a formação via deposição a seco, em condições de baixos valores de umidade relativa do ar, pela sulfatação da calcita (Reação 3), e posterior oxidação do sulfito de cálcio gerado inicialmente (Reação 4).

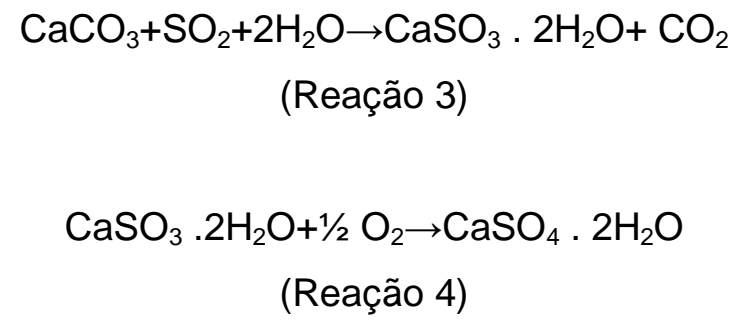

A segunda maneira é a formação da gipsita peloprocesso de oxidação heterogênea do $\mathrm{SO}_{2}$ em fase aquosa, podendo o acido sulfúrico ser formado tanto na atmosfera e precipitar na forma de chuva, como sobre a própria superfície pétrea na presença de um filme líquido. Em ambos os casos o ácido sulfúrico gerado dissolve a calcita para formar a gipsita, segundo as reações (Reações 5 e 6):

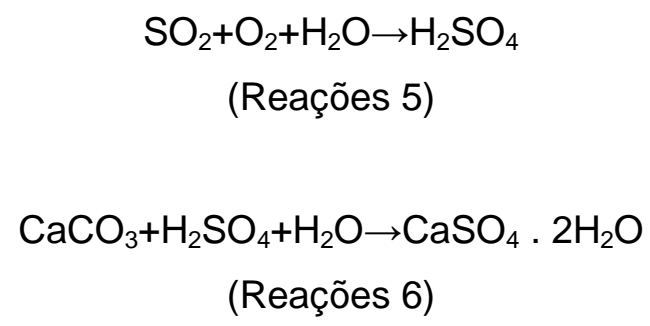

Furlan e Girardet (1983) afirmam que a deposição a seco é mais importante que a deposição via úmida em áreas muito poluídas.

- Desenvolvimento de crostas negras em áreas isoladas, que permaneçam úmidas por um longo período de tempo, entretanto protegidas da ação direta da chuva, impossibilitando a lixiviação dos depósitos (Figura 146). 


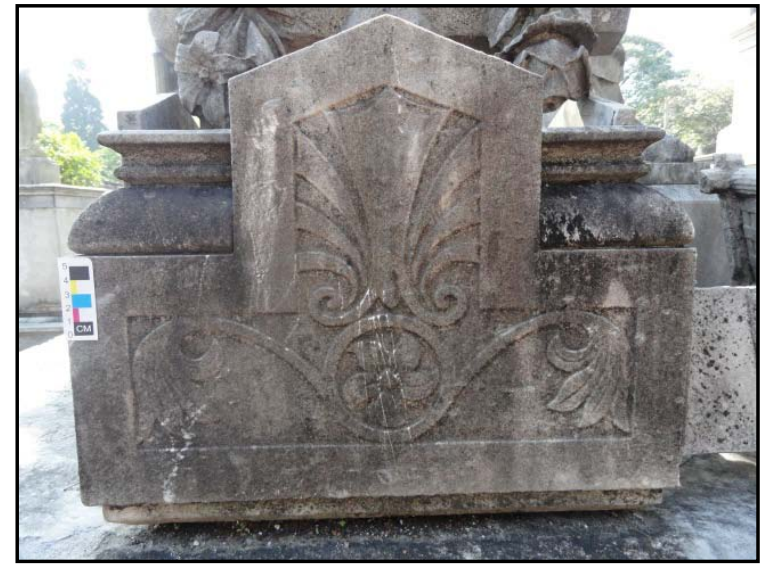

Figura 144. Escurecimento do mármore devido à presença de depósitos de fuligem.

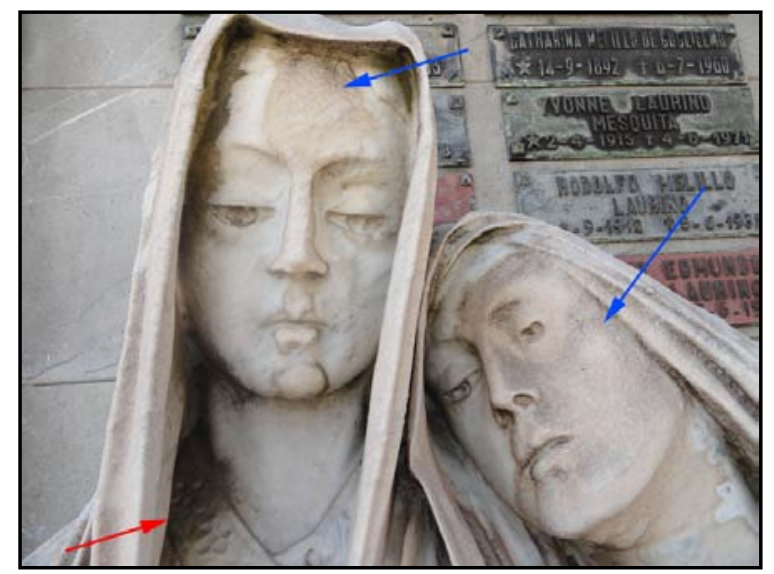

Figura 146. Setas azuis indicando zonas com desagregação granular, dissolução e alteração cromática. Seta vermelha indica presença de crosta negra.

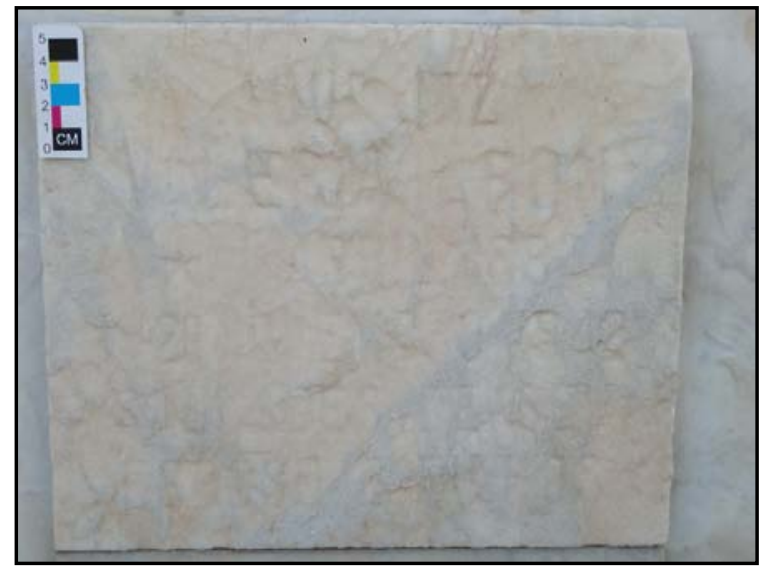

Figura 145. Perda da definição da lápide devido à dissolução do mármore.

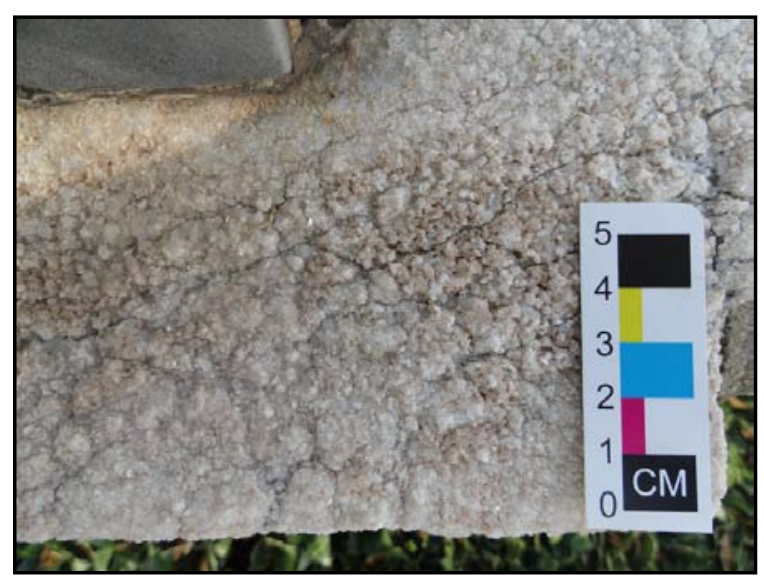

Figura 147. Desagregação granular e fissuramento do mármore.

\subsection{COLONIZAÇÃO BIOLÓGICA}

As colonizações biológicas causam muitos problemas à integridade das rochas. Além da sua alteração cromática, já discutida anteriormente, as plantas superiores causam grandes danos na estrutura dos túmulos. A penetração de raízes nos jazigos pode causar o fraturamento da rocha, assim como o colapso de parte da suaestrutura (Figuras 148 e 149). As raízes ainda podem promover a alteração de alguns minerais, devido à liberação de dióxido de carbono, que combinado com a água, gera o ácido carbônico (Reação 1). 


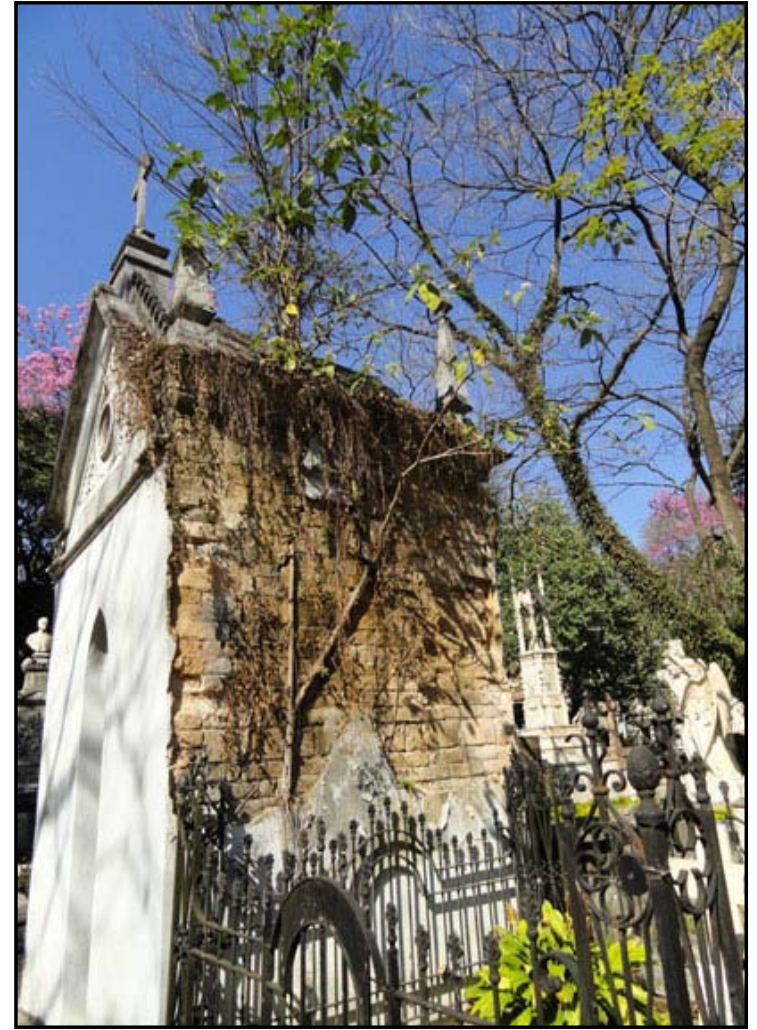

Figura 148. Perda do reboco do túmulo devido à ação de raízes.

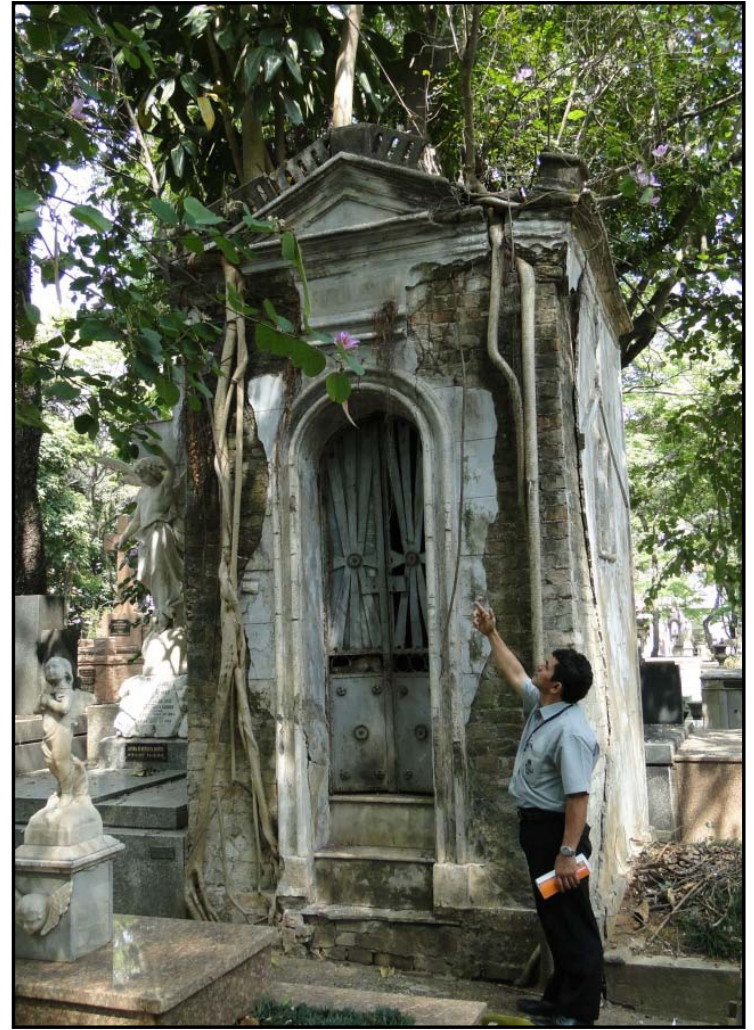

Figura 149. Perda do reboco do túmulo devido à ação de raízes.

\subsection{CONDIÇÕES CLIMÁTICAS}

O clima influencia na velocidade do intemperismo das rochas devido a mudanças no conjunto das condições meteorológicas reinantes, que no caso do Cemitério da Consolação, engloba oregime de chuva, vento e temperatura.

O Cemitério da Consolação apresenta doismicroclimas distintos (Figura 150), definidos pela presença ou não de árvores, um fator importante que influencia muitos outros parâmetros físicos como: maior ou menor exposição aos raios solares, incidência de ventos, umidade, colonização biológica por fungos, musgos, além de pássaros.

O microclima 1 (Figura 151) é o que apresenta maior quantidade de árvores, constituindo um ambiente mais úmido e com temperaturas mais baixas do que as zonas sem árvores. Nesse sistema, o intemperismo químico e biológico prevalecem, devido principalmente ao maior acúmulo de água e sua dificuldade de evaporação, o que facilita a proliferação de colonização biológica, esta por sua vez, libera ácidos orgânicos que em combinação com o ácido carbônico e a água, aceleram a decomposição química das rochas pelas reações de hidrólise.

O microclima 2 (Figura 152) é o que apresenta pouca quantidade de árvores e portanto os túmulos estão mais expostos aos raios solares.Nesse caso, o intemperismo físico 
apresenta maior importância na degradação das rochas, devido aos choques térmicos gerados pelas diferenças de temperatura entre os dias e as noites ou ainda devido à evaporação da água que percolou nas fraturas. Nesse microclima o intemperismo químico também está presente, entretanto vinculado mais a deposição a seco dos poluentes.

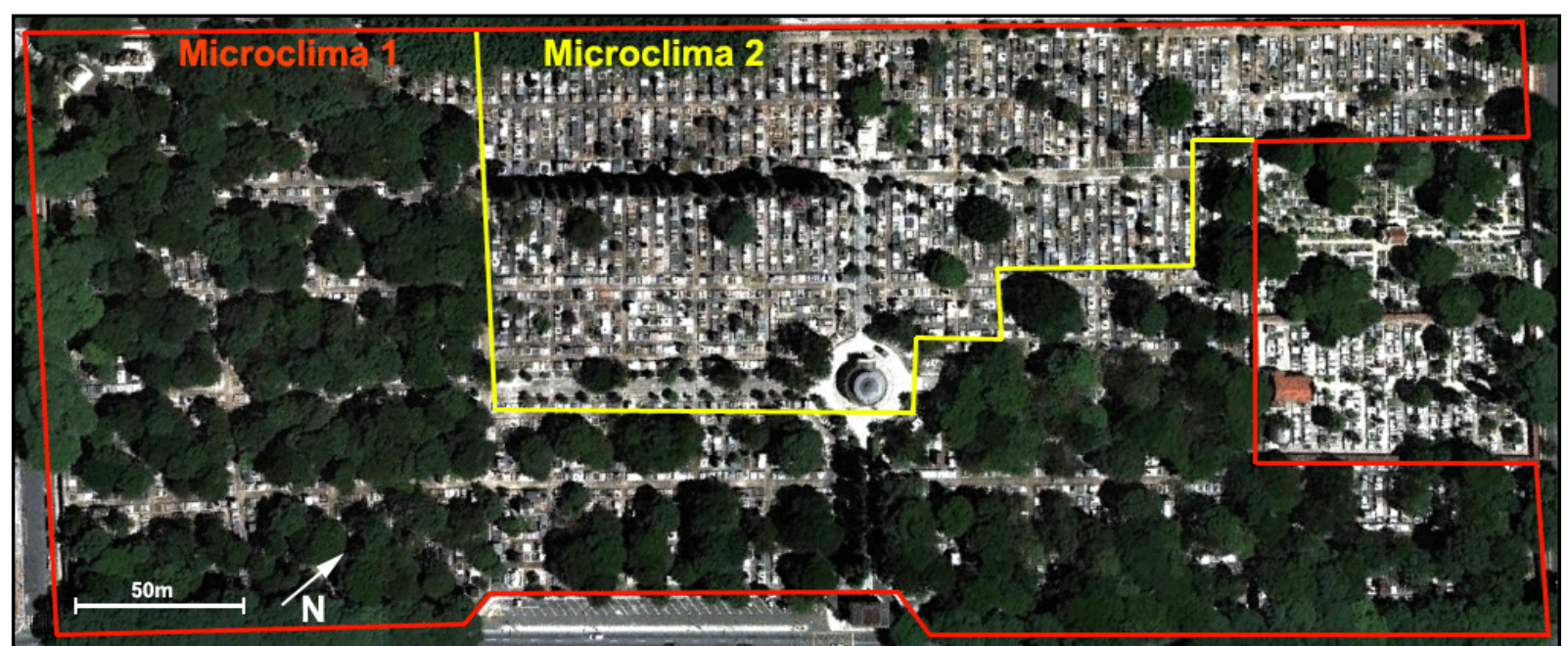

Figura 150. Área do Cemitério da Consolação delimitada pela linha vermelha. Microclimas 1 e 2 delimitados pela linha amarela.

Fonte: Adaptado do Google Earth.

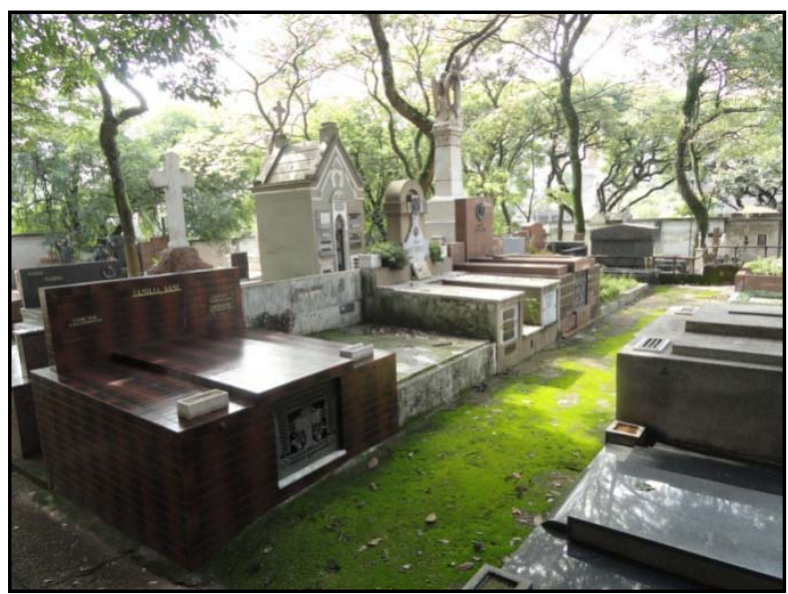

Figura 151. Microclima 1, ambiente úmido e com grande quantidade de árvores. Notar musgos colonizando a pavimentação.

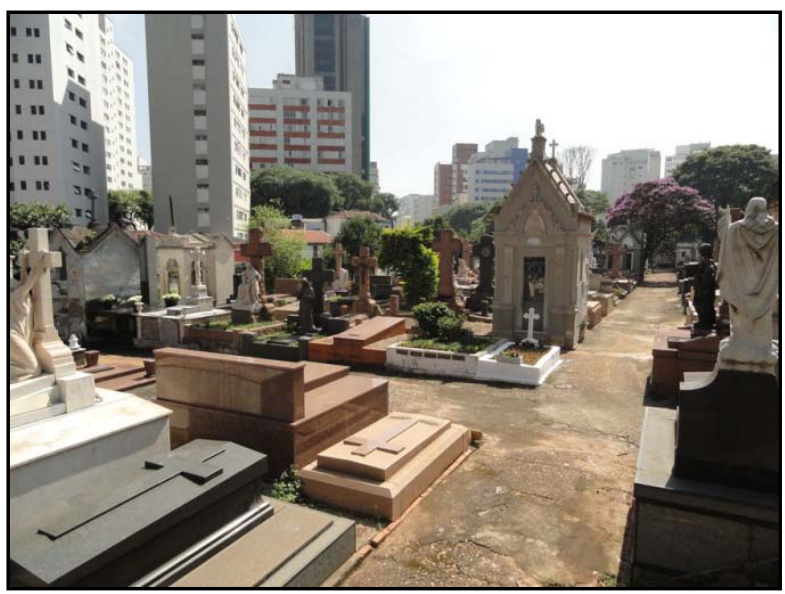

Figura 152. Microclima 2, ambiente seco, onde o intemperismo físico prevalece.

As Figuras 153 a 155 mostram a variação do ambiente de exposição do túmulo do expresidente do Estado de São Paulo Bernardino de Campos, construído pelo escultor italiano Julio Starace. Nota-se que o jazigo apresentava grande incidência de raios solares até a década de 1970, subsequentemente ocorrendo o crescimento de árvores, que proporcionaram ao túmulo menor exposição solar, aumento da umidade e maior possibilidade de proliferação de colonização biológica. 


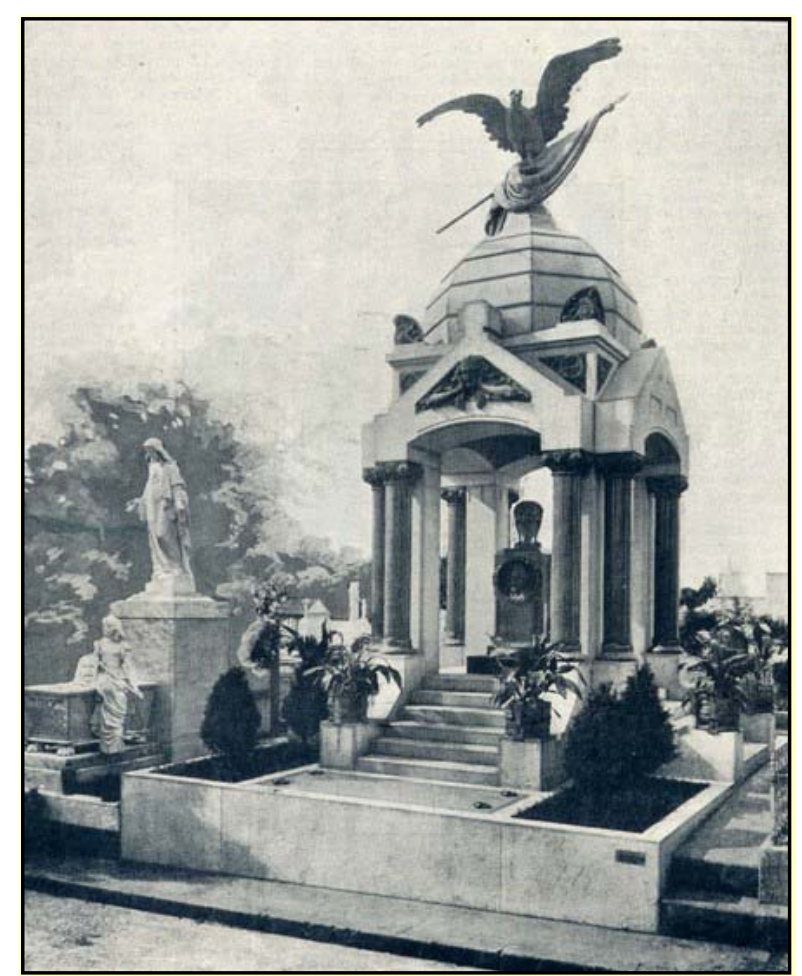

Figura 153. Túmulo do ex-presidente do Estado de São Paulo Bernardino de Campos em 1919. Fonte: Revista A Cigarra.

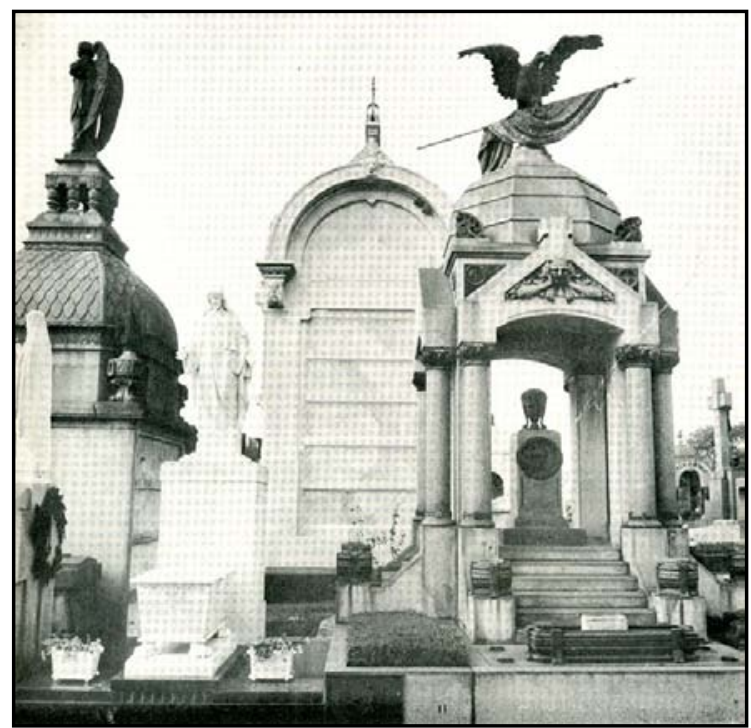

Figura 154. Túmulo do ex-presidente do Estado de São Paulo Bernardino de Campos na década de 1970.

Fonte: Valladares, 1972.

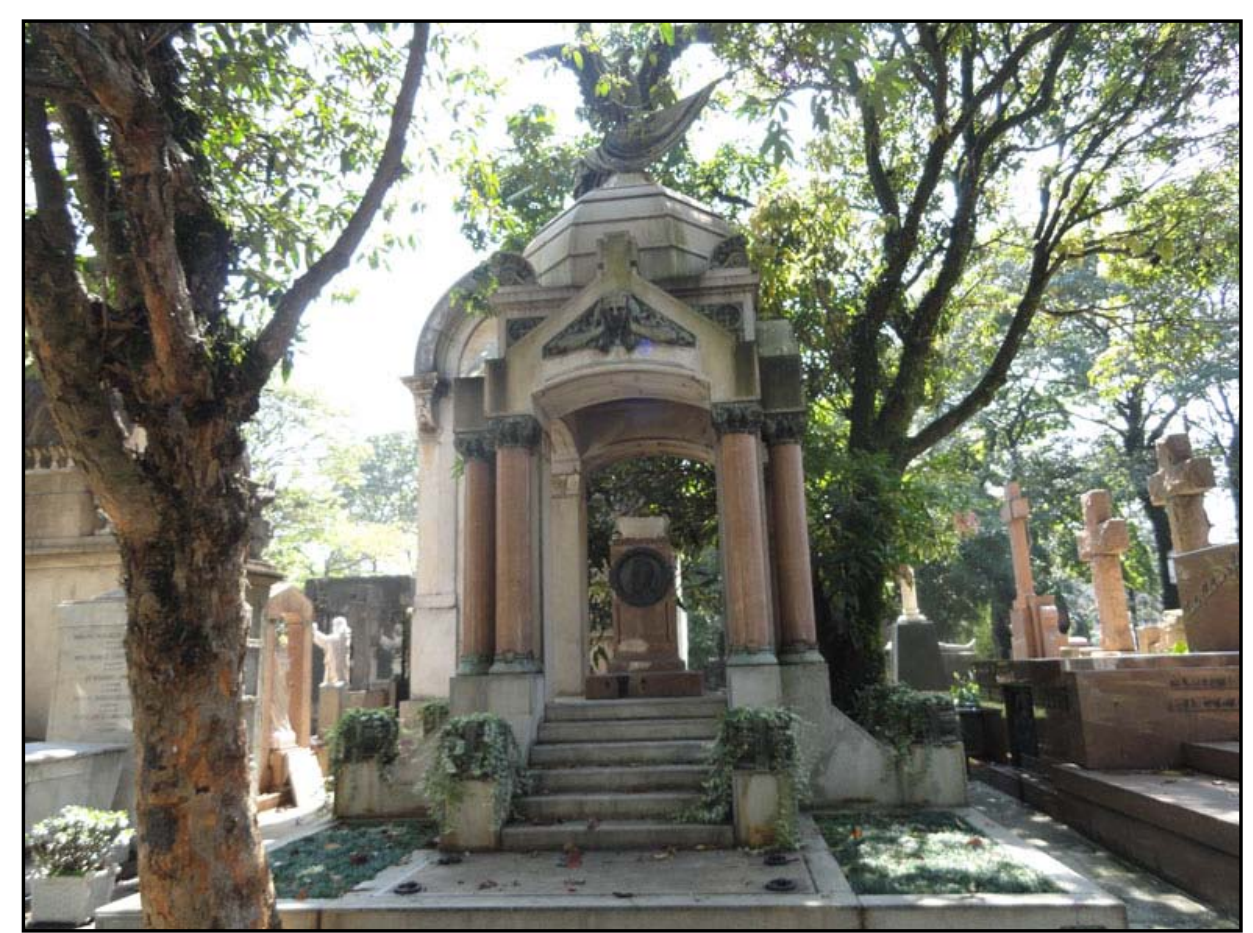

Figura 155. Túmulo do ex-presidente do Estado de São Paulo Bernardino de Campos em 2013. 


\subsection{CARACTERÍSTICAS ARQUITETÔNICAS}

Muitos túmulos e estátuas apresentam características arquitetônicas que não facilitam o escoamento da água, fazendo com que a mesma permaneça em contato com a superfície por mais tempo. Isso pode gerar muitos problemas, como colonização biológica; alteração dos minerais constituintes da rocha, levando a sua perda de coesão; modificação nas cores, etc. Um exemplo desse problema é a estátua Interrogação do escultor Francisco Leopoldo e Silva, que apresenta acumulação de água no cruzamento das pernas da estátua como indicado na Figura 156. A água não apresenta possibilidade de escoamento e como a estátua está localizada numa região do cemitério com muitas árvores e jazigos altos, mesmo em dias ensolarados, o túmulo recebe pouca insolação. O acúmulo de água promove a proliferação de micro-organismos e alteração cromática da região como é vista na Figura 157. Devido ao programa de combate a dengue da prefeitura da cidade de São Paulo, posteriormente foi verificada a adição de areia na região (Figura 158), a fim de evitar o acúmulo da água parada. Essa atitude não eliminou o problema, pois a região permanece úmida, colaborando com a proliferação biológica, podendo até facilitá-la, devido à maior dificuldade de evaporação da água.

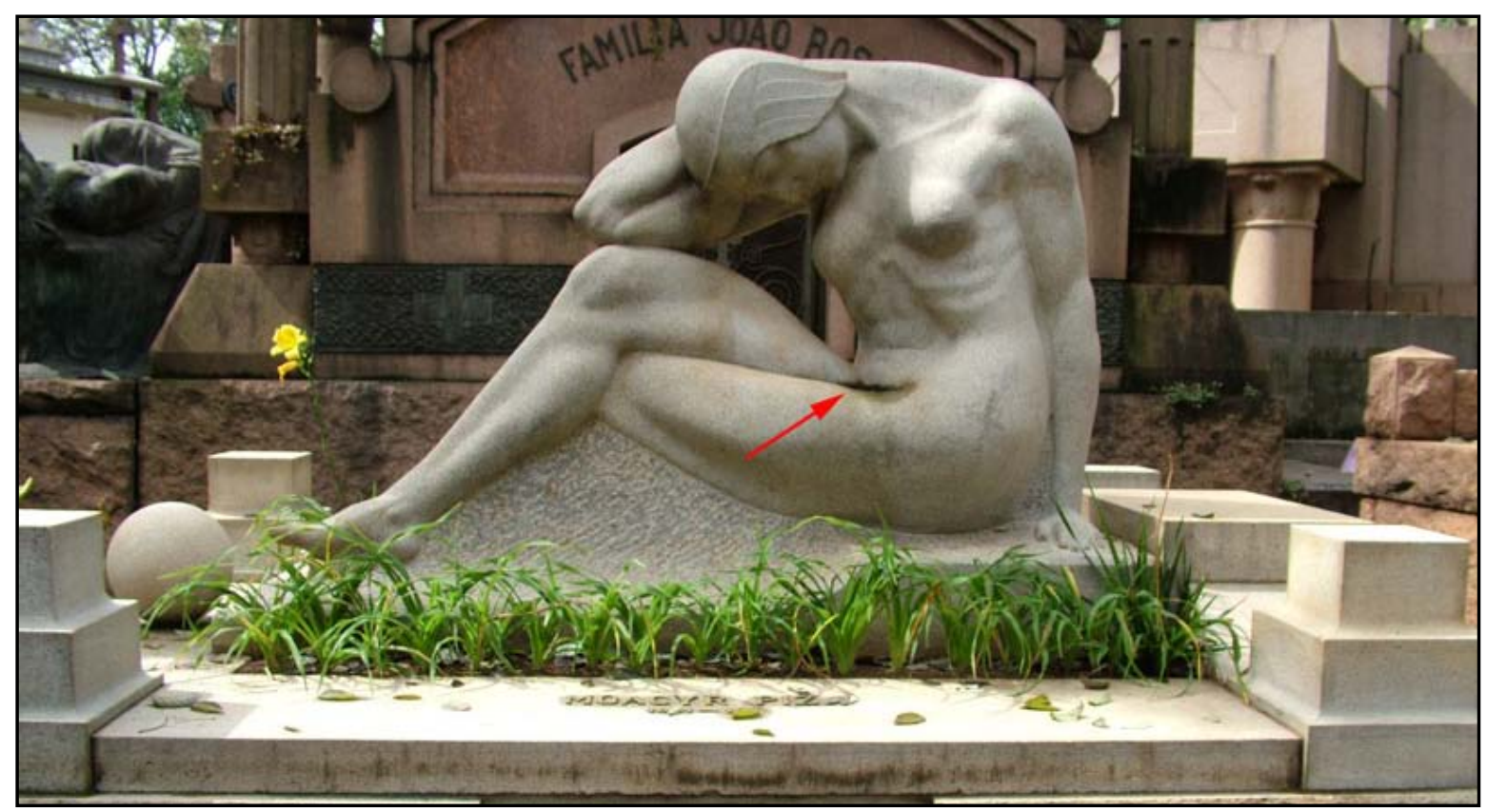

Figura 156. Escultura Interrogação de Francisco Leopoldo e Silva. Seta indica zona com acúmulo de água. 


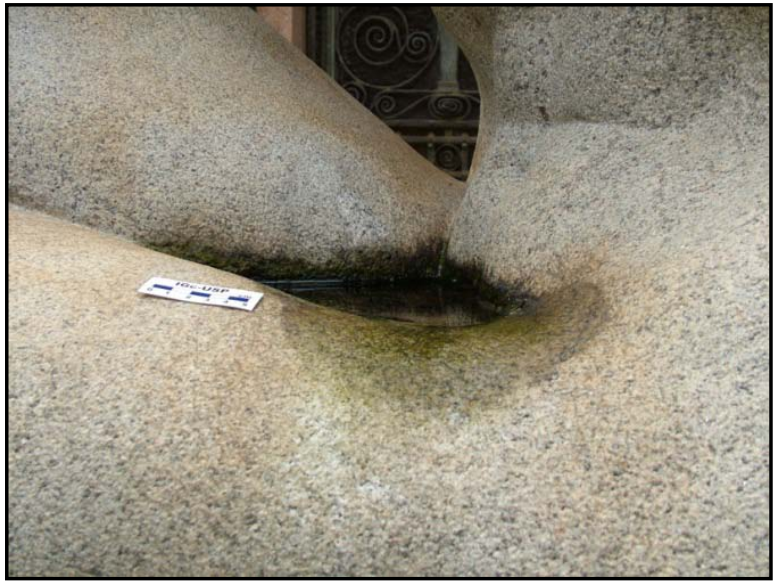

Figura 157. Zona com acúmulo de água, notando-se proliferação de micro-organismos e alteração cromática da região.

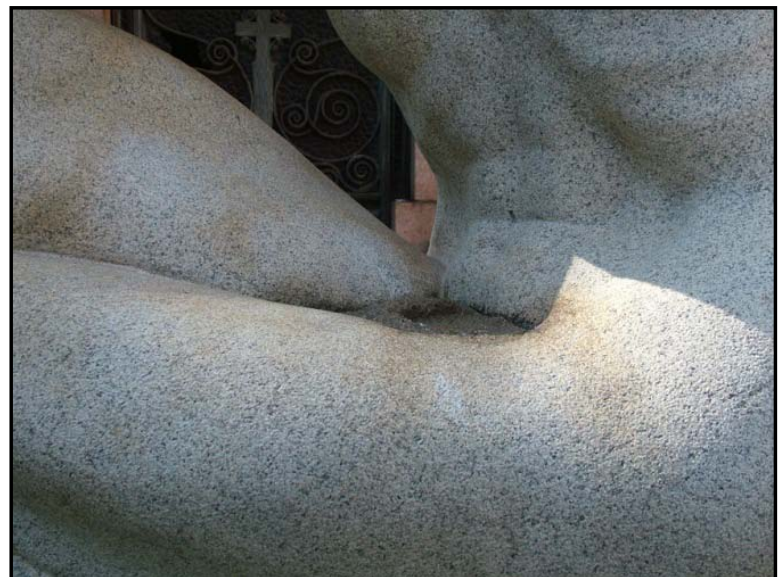

Figura 158. Adição de areia a zona de acúmulo de água.

\subsection{VANDALISMO}

Um dos problemas mais sérios encontrados no Cemitério da Consolação são osfrequentes atos de vandalismos. Desde pichações, roubo de ornatos em bronze e quebra de estátuas e alegorias, o cemitério vai perdendo progressivamente o seu acervo cultural. Um dos atos de vandalismos mais divulgados foi o que ocorreu no ano de 2000 , que levou a completa depredação de um anjo em cerâmica com asas de alumínio, datado de 1970, de autoria do artista italiano Fulvio Pennacchi.

Atualmente as pichações e a quebra dos ornatos diminuíram bastante e apesar desses atos ainda estarem presentes por toda a necrópole, são os roubos de vasos, portões, jardineiras, placas, argolas e letreiros em bronze que estão aumentando nos últimos anos.

$\mathrm{Na}$ reportagem realizada pelo jornal Folha de São Paulo intitulada Cemitério da Consolação registra aumento no número de furtos (Anexo2), é enfatizado o aumento dos roubos, atingindo cerca de 300 furtos no mês de setembro de 2011. Funcionários do cemitério comentam que nunca presenciaram uma quantidade tão grande de roubos, que não se restringem mais aos horários após o fechamento do cemitério (Anexo 3). Segundo a reportagem, o principal motivo dos roubos são os valores pagos pelos metais, no mercado de ferro velho, uma peça de bronze é vendida por cerca de $R \$ 5$ o quilo, de cobre $R \$ 9$ o quilo.

$\mathrm{Na}$ reportagem realizada pelo jornal Folha de São Paulo intitulada Prefeitura vai instalar câmeras nos cemitérios de São Paulo (Anexo4), estava previsto para o primeiro semestre de 2012 a instalação de câmeras de segurança pelos cemitérios de São Paulo. Até o começo do ano de 2013, no Cemitério da Consolação, ainda não tinham sido instaladas. 
O patrimônio cultural possui mecanismos jurídicos de proteção, abrangendo a seguinte lei federal (Brasil - Presidência da República, 1998):

“Lei Federal No 9.605 de 12 de fevereiro de 1998: Capitulo V - Seção IV - Dos Crimes Contra o Ordenamento Urbano e o Patrimônio Cultural

Art 62. Destruir, inutilizar ou deteriorar: I - bem especialmente protegido por lei, ato administrativo ou decisão judicial; II - arquivo, registro, museu, biblioteca, pinacoteca, instalação científica ou similar protegido por lei, ato administrativo ou decisão judicial. Pena reclusão, de um a três anos, e multa. Parágrafo único - Se o crime for culposo, a pena é de seis meses a um ano de detenção, sem prejuízo da multa.

Art 63. Alterar o aspecto ou estrutura de edificação ou local especialmente protegido por lei, ato administrativo ou decisão judicial, em razão de seu valor paisagístico, ecológico, turístico, artístico, histórico, cultural, religioso, arqueológico, etnográfico ou monumental, sem autorização da autoridade competente ou em desacordo com a concedida. Pena reclusão, de um a três anos, e multa.

Art 65. Pichar, grafitar ou por outro meio conspurcar edificação ou monumento urbano:

Pena - detenção, de três meses a um ano, e multa. Parágrafo único. "Se o ato for realizado em monumento ou coisa tombada em virtude do seu valor artístico, arqueológico ou histórico, a pena é de seis meses a um ano de detenção, e multa."

Atualmente, o Serviço Funerário, com o apoio da Guarda Civil Metropolitana, aumentou a vigilância do cemitério, realizando nove prisões em flagrante no ano de 2011. Mesmo assim, uma área de aproximadamente $77.000 \mathrm{~m}^{2}$ apresenta dificuldades de ser vigiadageralmente por dois policiais motorizados. As leis existem, mas se mostram insuficientes para conter os atos de vandalismo (Figuras 159 a 165). 


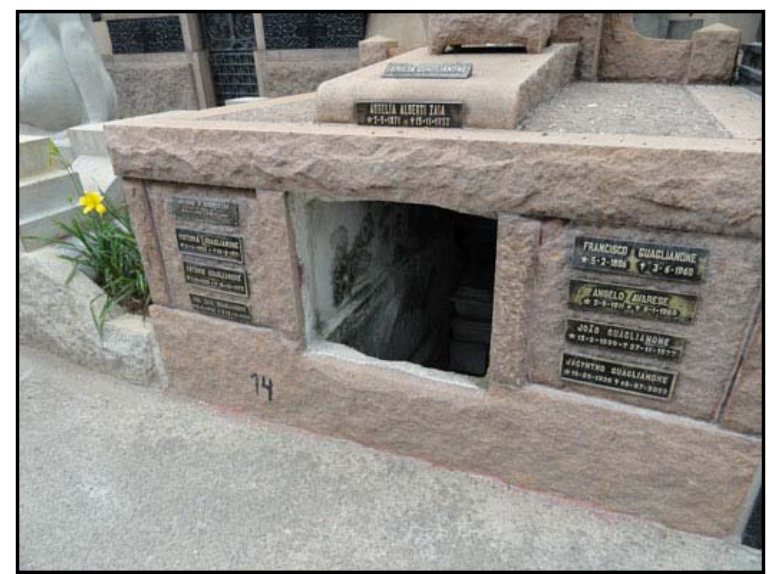

Figura 159. Ausência do portão de bronze.

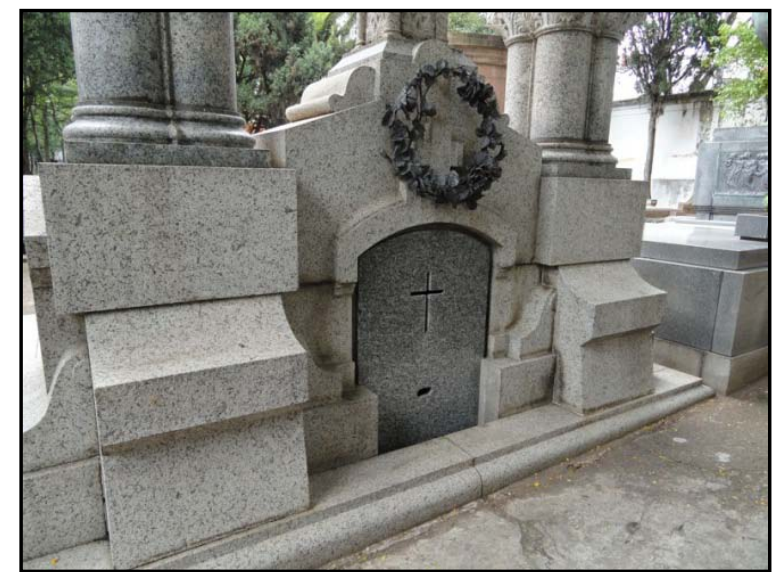

Figura 160. Colocação de um portão em rocha devido o roubo do antigo portão em bronze.

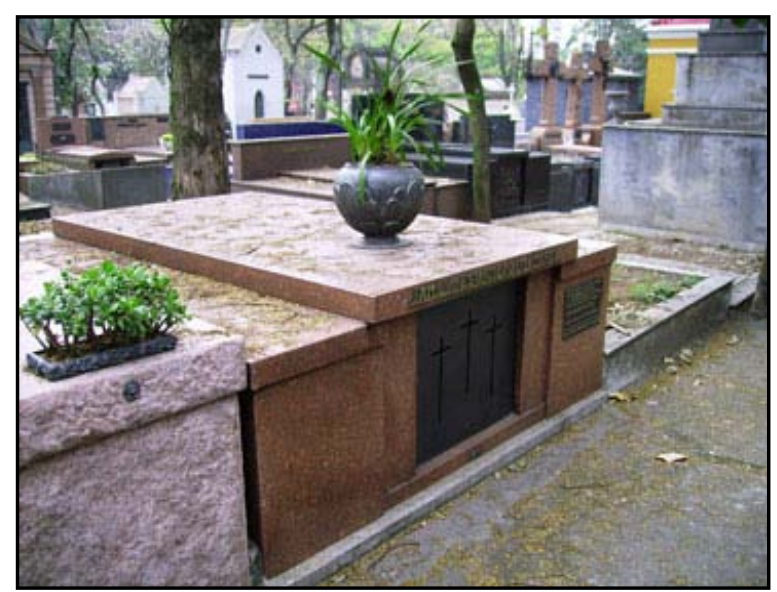

Figura 161. Túmulo da pintora Tarsila do Amaral no dia 10 de fevereiro de 2008.

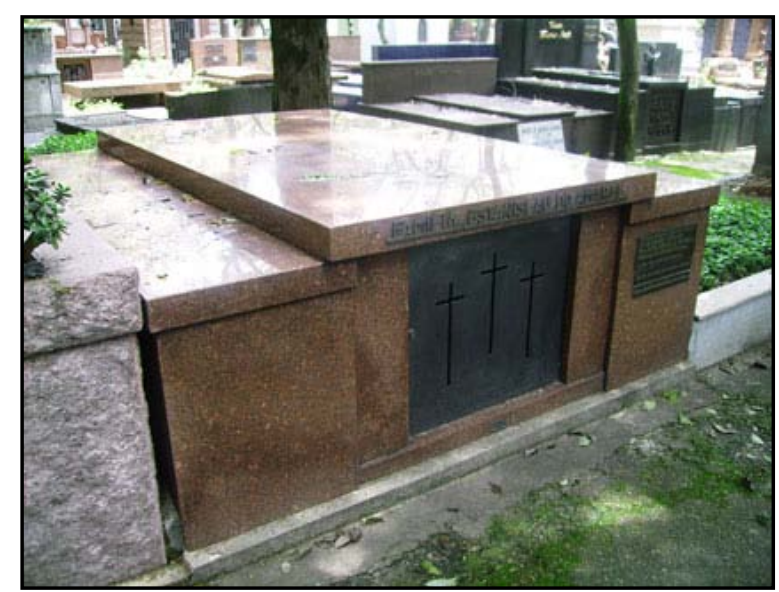

Figura 162. Túmulo da pintora Tarsila do Amaral no dia 22 de janeiro de 2009. Ausência do vaso de bronze. 


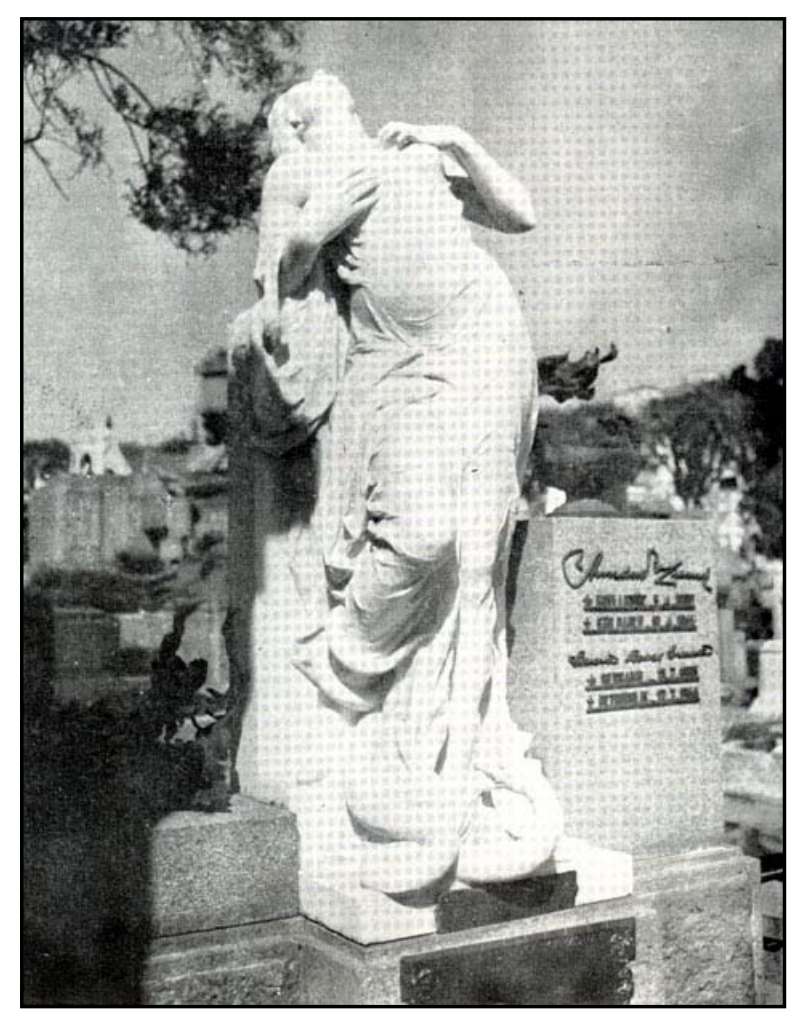

Figura 163. Túmulo de Luisa Crema Marzoratti, fotografado entre os anos de 1960 e 1970, apresentando todas as suas alegorias em perfeito estado de conservação.

Fonte: Valladares (1972).

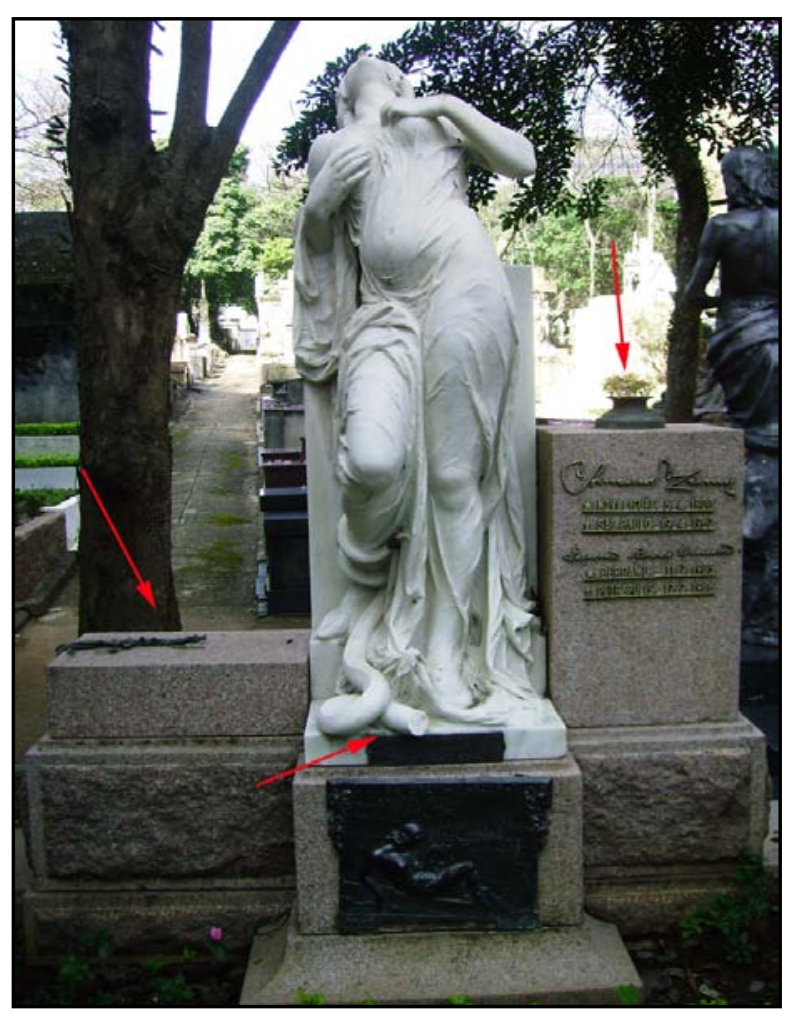

Figura 164. Túmulo de Luisa Crema Marzoratti, fotografado no dia 26 de junho de 2008. As setas vermelhas indicam a ausência de elementos da composição.

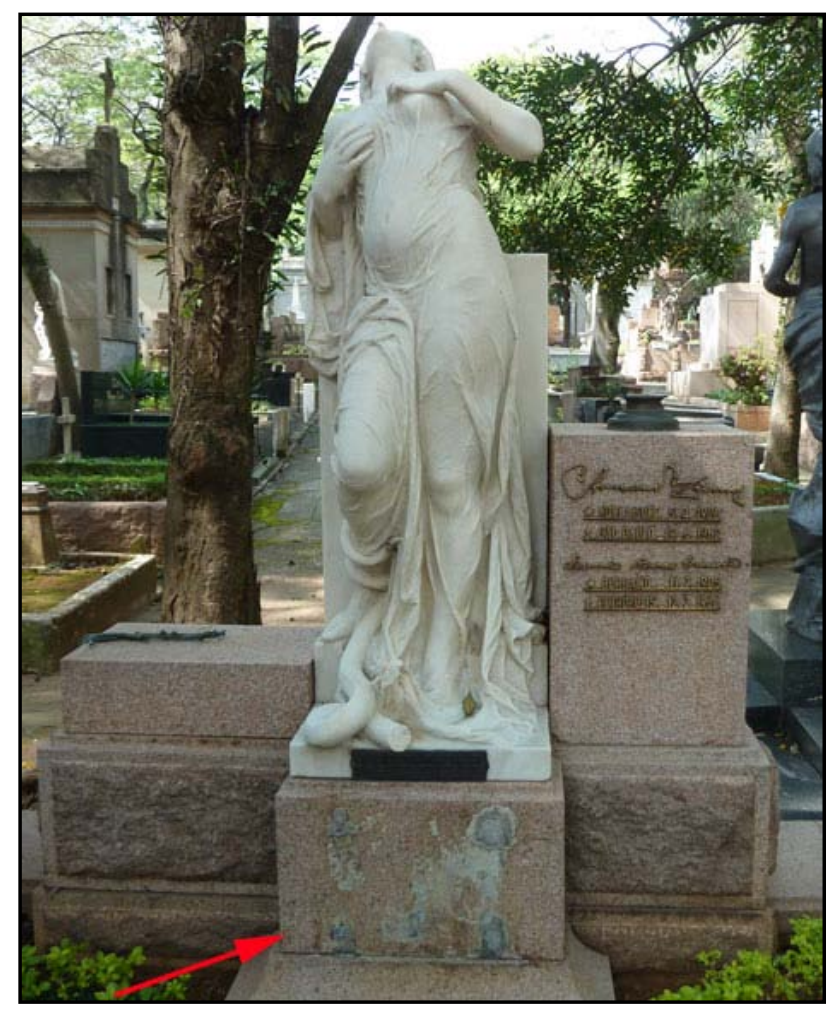

Figura 165. Túmulo de Luisa Crema Marzoratti, fotografado no dia 02 de abril de 2012. A seta em vermelho indica a perda de mais um elemento do túmulo. 
Notou-se que ainda que alguns túmulos apresentam indícios de serem utilizados para pernoite, devido à presença de papelão, roupas e em alguns casos fezes (Figura 166). Foi presenciado indivíduos lavando roupa, com as mesmas sendo estendidas nos túmulos, e tomando banho nas torneiras do cemitério (Figura 167).

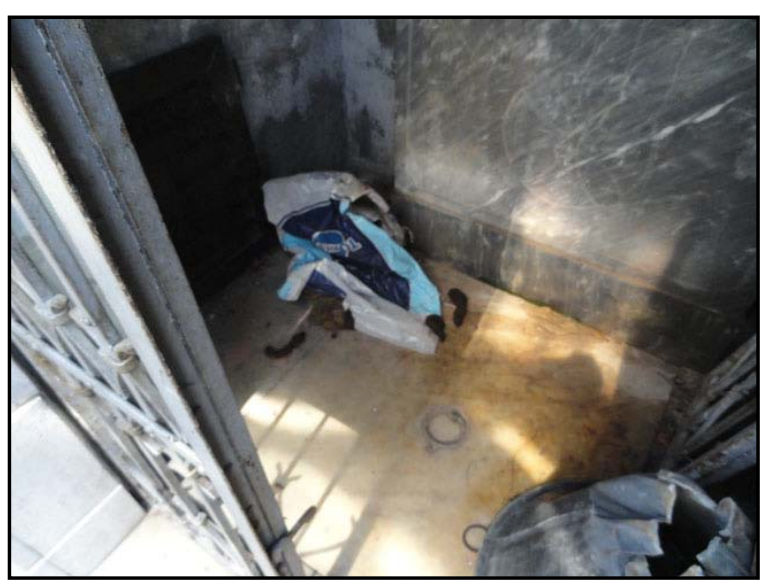

Figura 166. Bastante sujeira e fezes dentro de jazigo.

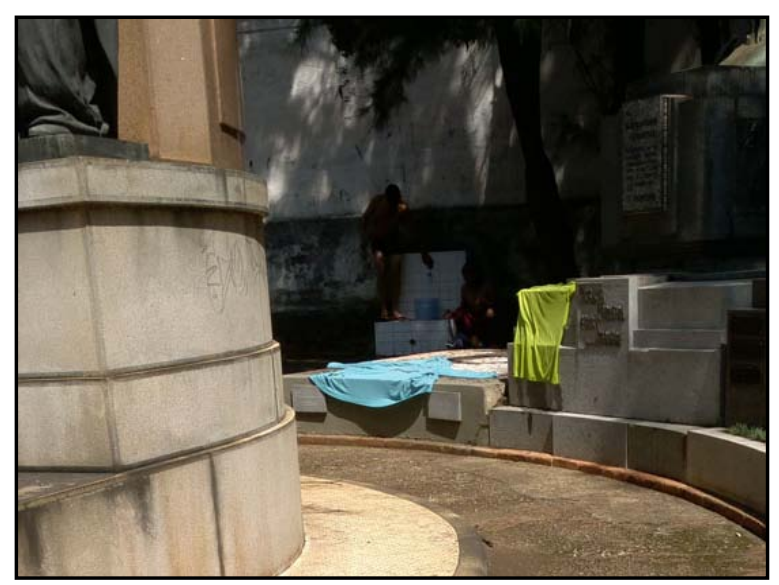

Figura 167. Indivíduos tomando banho e lavando roupa numa torneira no cemitério.

\subsection{FALTA DE GERENCIAMENTO}

Uma grande discussão a respeito do Cemitério da Consolação é a quem compete a administração, conservação e segurança dos túmulos. Em entrevista a Folha de São Paulo (Anexo 2), a prefeitura de São Paulo afirma:

“...as famílias pagam pela concessão do terreno $\left(\mathrm{R} \$ 3.173 / \mathrm{m}^{2}\right)$ e devem custear a conservação e a segurança, isentando o Serviço Funerário de quaisquer responsabilidades administrativa, civil e criminal no caso de furtos de materiais de valor."

Tal afirmação é completamente equivocada, pois nos termos do artigo 23 da Constituição Federal de 1988, éda competência comum da União, dos Estados, do Distrito Federal e dos Municípiosproteger os documentos, as obras e outros bens de valor histórico, artístico e cultural, os monumentos, as paisagens naturais notáveis e os sítios arqueológicos; impedir a evasão, a destruição e a descaracterização de obras de arte e de outros bens de valor histórico, artístico ou cultural; e proporcionar os meios de acesso à cultura, à educação e à ciência.

Entretanto, os proprietários dos túmulos não estão completamente isentos de responsabilidade. Segundo Cangussu e Cabral (2012), o proprietário do objeto tombado, que não dispuser de recursos para proceder às obras de conservação e reparação que a mesma requer, deverá levar ao conhecimento do órgão de conservação a necessidade das 
mencionadas obras, sob pena de multa correspondente ao dobro da importância em que for avaliado o dano sofrido pelo mesmo objeto. Destaca-se ainda, que nocaso de extravio ou furto de qualquer objeto tombado, o respectivo proprietário deverádar conhecimento do fato ao órgão de conservação dentro do prazo de cinco dias, sob pena de multa de $10 \%$ sobre o valor do bem. Da mesma maneira que os proprietários, o Serviço Funerário possui responsabilidades com os jazigos do cemitério, pois são os que estão mais ligados a eles, principalmente no cuidado que se deve ter para realizar os sepultamentos nas campas tombadas.

Desta maneira, muitas pessoas possuem responsabilidadescom os jazigos do Cemitério da Consolação, desde a prefeitura, o órgão de tombamento, o serviço funerário e o dono propriamente. Entretanto, mais importante do que apontar culpados para a falta de conservação de muitos jazigos, é mostrar a grande importância que alguns túmulos possuem e a necessidade de intervenção adequada, planejada e estudada que necessitam. Serão apresentados os problemas do mausoléu da família Matarazzo e da família Siciliano.

\subsubsection{Mausoléu da Família Matarazzo}

A família Matarazzo ou mais especificamente o conde Francesco Matarazzo foi o maior empreendedor do Brasil em todos os tempos e um dos nomes de destaque do capitalismo mundial. Nascido na Itália em 1854, desembarcou em Santos (SP) em 1881 a procura de melhores condições de vida. Possuía uma visão de mercado surpreendente e com auxilio de empréstimos, começou a abrir casas comerciais e outros empreendimentos. A partir de 1900 seu império expandiu-serapidamente, chegando a reunir 365 fábricas por todo o país, que em 1911 passaram a se chamar Indústrias Reunidas Francisco Matarazzo (IRM). Em 1920 ergue o primeiro grande parque industrial do Brasil, na Água Branca, zona oeste de São Paulo. Em 1928 participa da fundação do Centro das Indústrias de São Paulo (atual FIESP), falecendo em dezembro de 1937 na capital paulista.

Ao morrer, Matarazzo possuía um patrimônio estimado em 20 bilhões de dólares corrigidos, chegando a ser a quinta maior fortuna do mundo e o italiano mais rico fora da Itália. Seus 20 bilhões de dólares em valores de hoje seriam suficientes para garantir a sexta posição na relação de milionários da revista Forbes (Blecher, 2004).

Após a sua morte, a condução dos negócios foi entregue a Francisco Matarazzo Júnior, um dos seus treze filhos. Os problemas ao redor dos negócios da família começaram na década de 1950, com o avanço da industrialização e o aumento da concorrência. Endividadas, as empresas foram vendidas uma a uma até a concordata no início dos anos de 1980. Pouco resta do que foi o Império Matarazzo, a mansão da família na Avenida 
Paulista foi demolida no inicio da década de 1990, do complexo industrial da Água Branca resta atualmente a antiga casa das caldeiras, com suas três chaminés, e a casa de força, o restante dasestruturas foidemolido em 2010 para abrigar prédios comerciais. Até mesmo o complexo industrial localizado no município de São Caetano foi completamente demolido no final de 2012. Como se vê, pouco a pouco o legado deixado pelo maior industrial brasileiro vai desaparecendo, restando hoje o Edifício Matarazzo, antiga sede das IRM, abrigando atualmente a sede da Prefeitura de São Paulo e o mausoléu da família no Cemitério da Consolação.

Construído pela oficina de arte tumulária de Luigi Brizzolara em Gênova, Itália, e trazido de navio para o Brasil, o mausoléu da família Matarazzo é considerado o maior da América Latina, tratando-se provavelmente do maior e mais custoso mausoléu de família construído em cemitério brasileiro. Do subsolo ao pico possui 25 metros de altura, ocupa uma área de 150 metros quadrados, com capacidade para 60 cadáveres e mais ossário, possuiainda uma capela no seu interior.

Na sua confecção foram utilizados vários tipos de rochas. A parte exterior é revestida por granito avermelhado, as cercaduras das portas por calcário fossilífero, a soleira da porta principal por um tipo de mármore importado e todo o calçamento ao redor do mausoléu por travertino. A estátua existente acima da porta também foi confeccionada em calcário fossilífero e todas as outras existentes em bronze.

O abandono que atingiu os outros patrimônios da família infelizmente também está presenteno mausoléu. Nota-se a nítida falta de administração do túmulo pelas variadas formas de deterioração existentes. O granito avermelhado que reveste todo o mausoléu apresenta várias formas de deterioração que afetam a leitura do túmulo, entre elas a alteração cromática que proporciona o enegrecimento da rocha (Figura 168) é a mais impactante. Nas zonas de escoamento da água da chuva que percorre as estátuas de bronze, nota-se alteração cromática com tonalidade verde (Figura 169), devido à precipitação do zinabre (pátina resultante da oxidação do cobre). Perda de partes relacionadas às quinas do mausoléu (Figura 170), incrustação (Figura 171) e grafite (Figura 172) também estão presentes. Orifícios gerados pela alteração de minerais opacos (Figura 173), fissuras e espaços entre os blocos de granito foram preenchidos por materiais (argamassa, cola epóxi e massa para vidraceiro) que não se mostraram adequados (Figuras 174 e 175). Salvo a argamassa, os outros materiais apresentam formas de alteração que promovem o escurecimento da rocha, além de gerarem um resíduo bastante aderente ao substrato. Em relação às formas de deterioração do calcário fossilífero, ocorrem eflorescências (Figura 176), crosta negra (Figura 177), rompimento (Figuras 178 e 179), alteração cromática para tons esverdeados devido à precipitação do zinabre, carregado pela água da chuva, e escurecimento devido à queima de velas (Figura 179) e erosão diferencial 
na estátua existente acima da cercadura da porta principal (fósseis mais resistentes ao intemperismo ficam evidentes, enquanto a matriz carbonática é alterada e lixiviada).

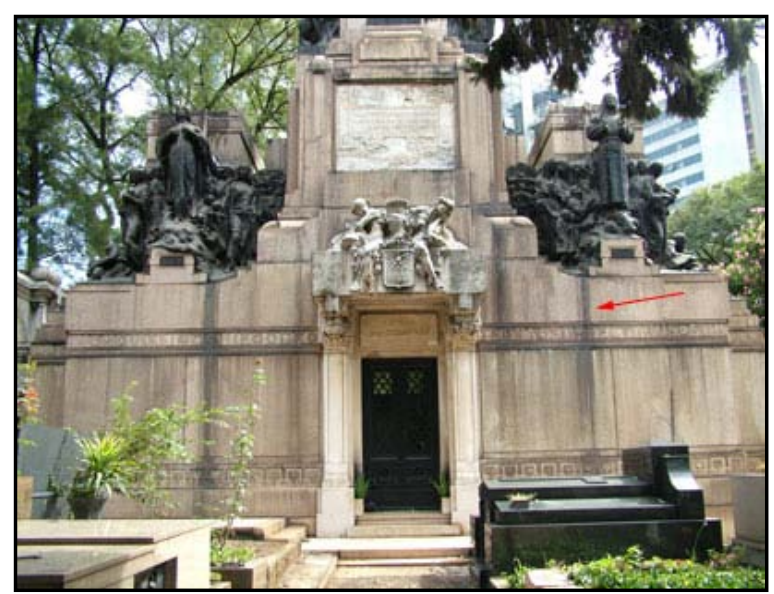

Figura 168. Notar alteração cromática por todo o mausoléu.

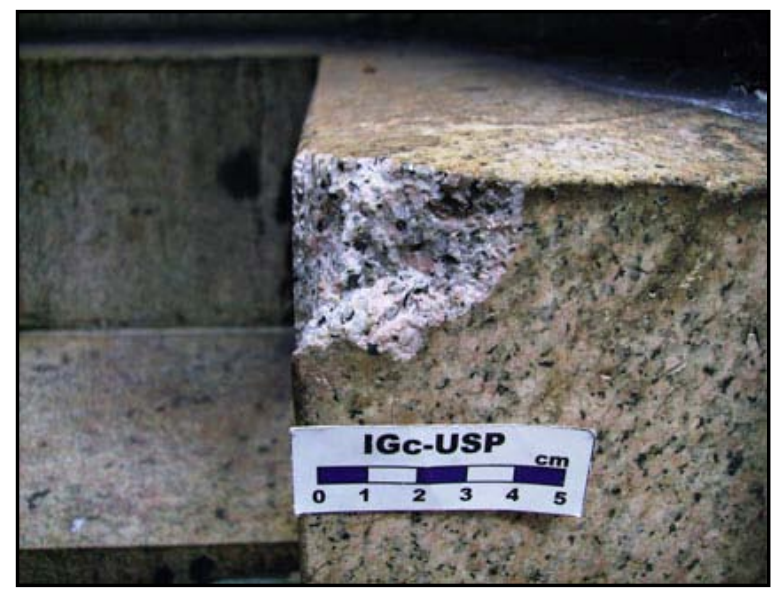

Figura 170. Perda de partes.

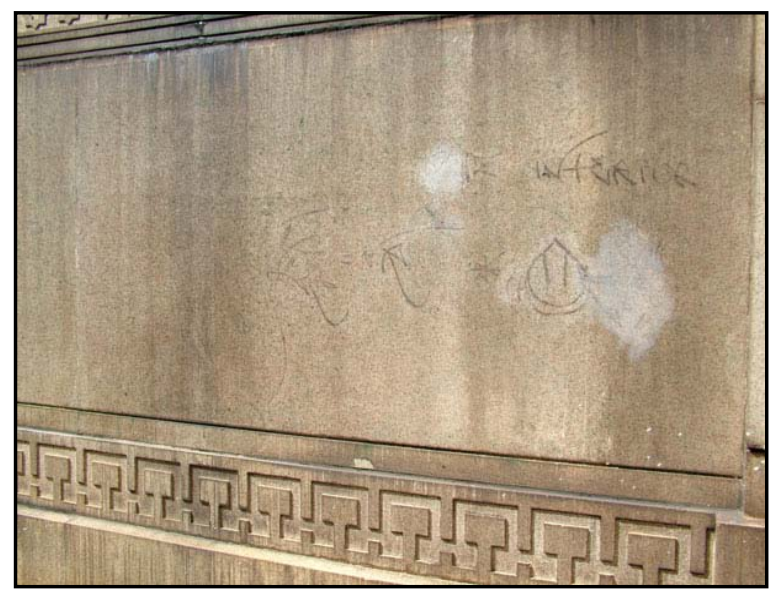

Figura 172. Grafite.

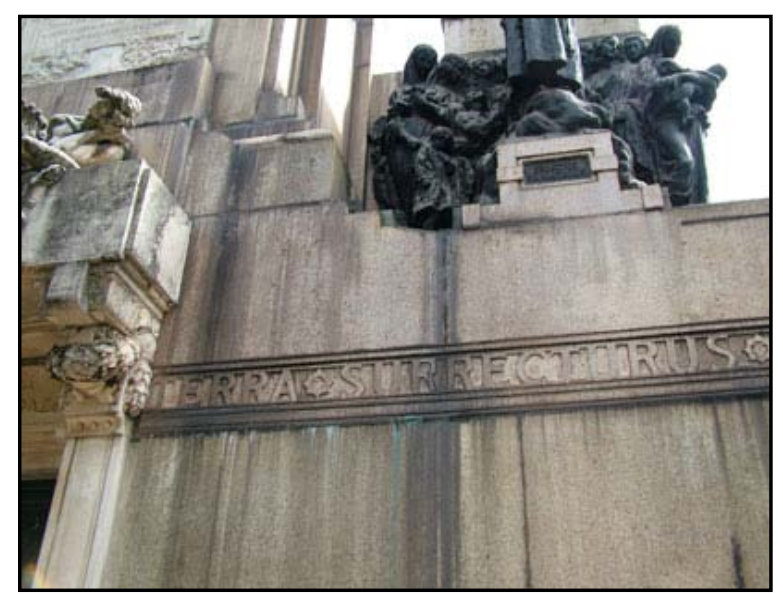

Figura 169. Alteração cromática devido à precipitação do zinabre proveniente das estátuas de bronze.

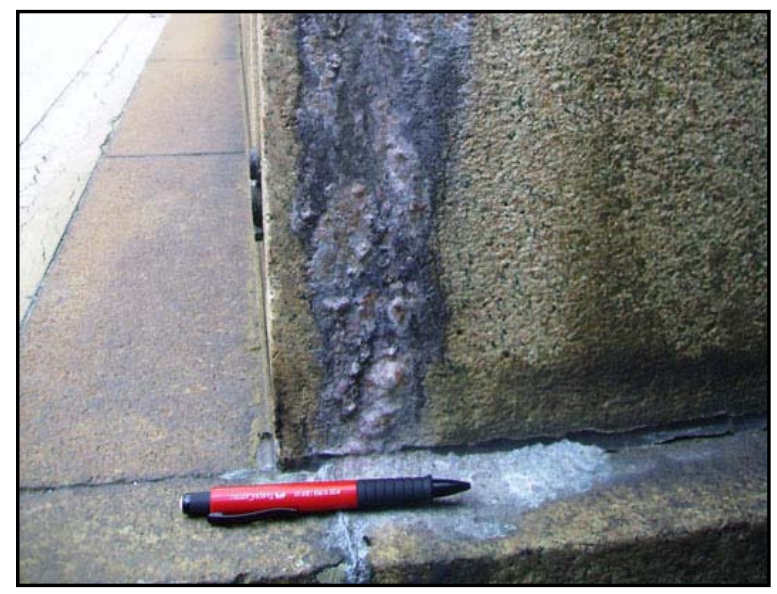

Figura 171. Incrustação.

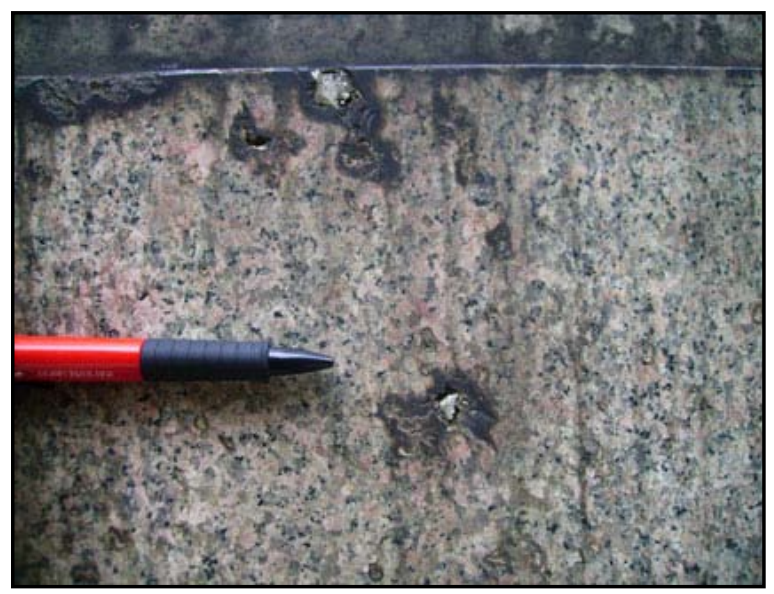

Figura 173. Orifícios, gerados pela alteração de minerais opacos, preenchidos com argamassa. 


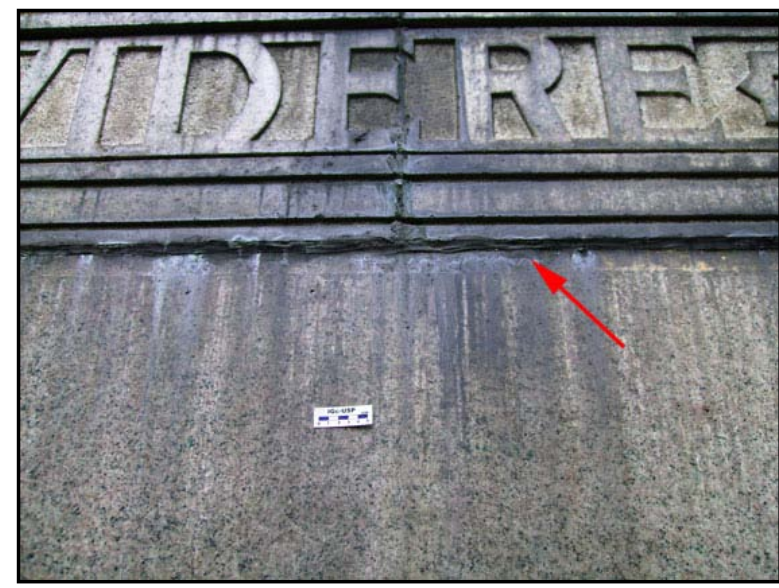

Figura 174. Material utilizado para rejunte dos blocos de granito não se mostrou adequado, proporcionando o escurecimento da rocha.

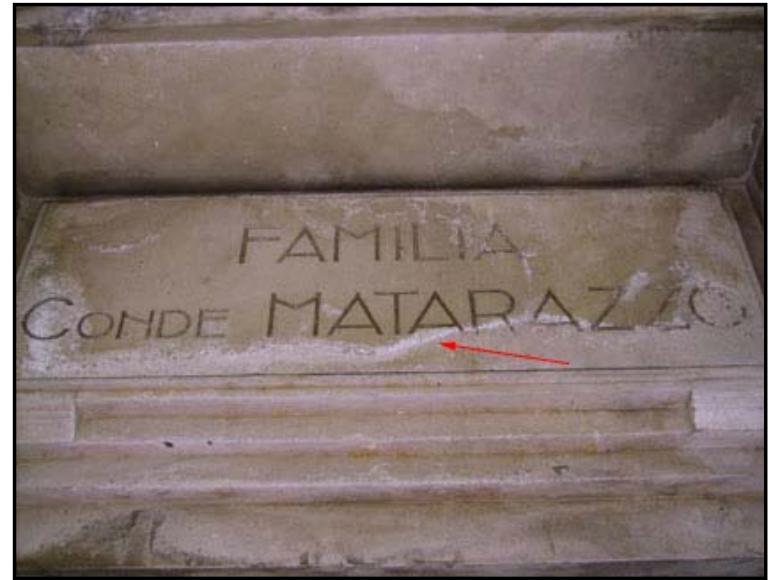

Figura 176. Eflorescência.

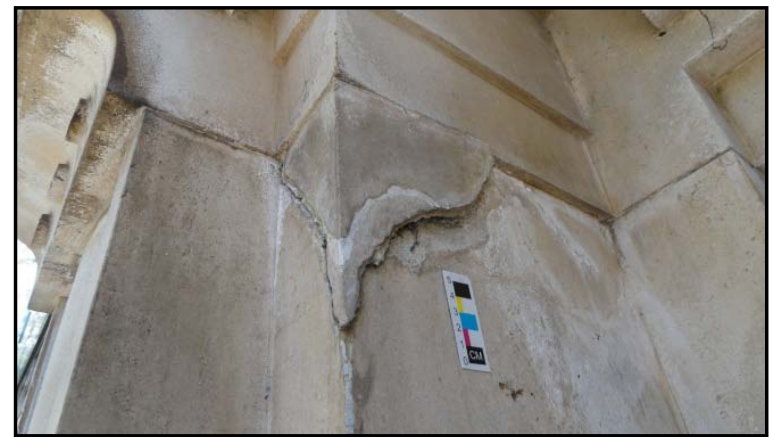

Figura 178. Rompimento.

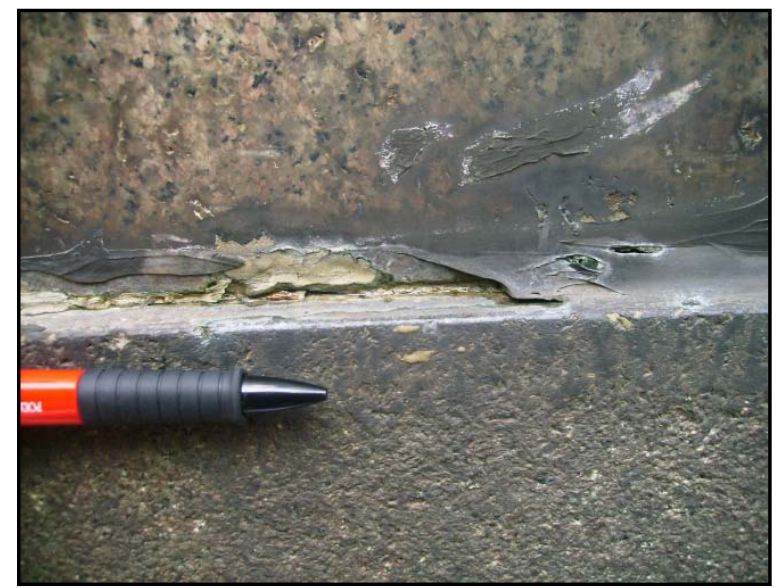

Figura 175. Detalhe do material utilizado no rejunte dos blocos.

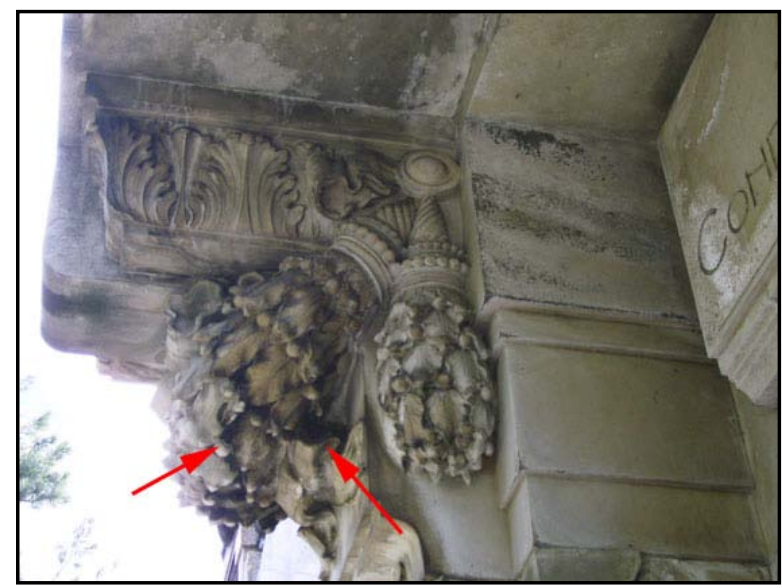

Figura 177. Crosta negra.

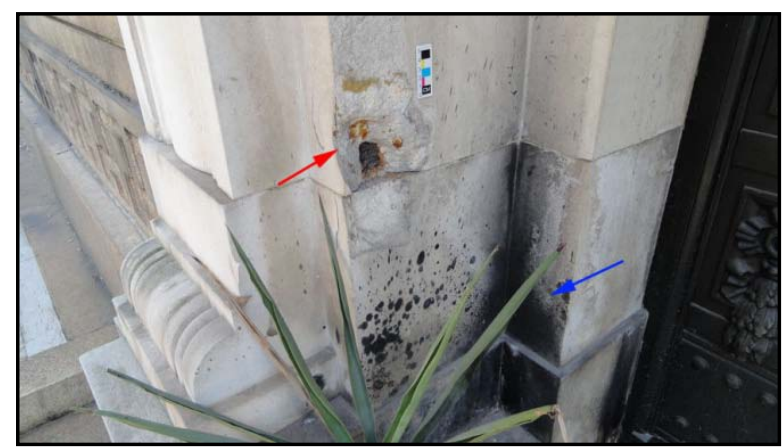

Figura 179. Seta vermelha indica local que já ocorreu o rompimento e a seta azul alteração cromática em função da queima de velas. 


\subsubsection{Mausoléu da Família Siciliano}

Conde Alessandre Vincenzo Siciliano nasceu na Itália em 1890, veio para o Brasil com nove anos de idade e faleceu em 1923. Tornou-se conde papalino em 1916, título obtido do Papa Benedito XV. Fundador, junto com seus familiares, do Banco Ítalo Brasileiro e de Companhia Mecânica e Importadora de São Paulo, foi um importante industrial e banqueiro no começo da década de 1900 (Carone, 2001). Propôs em 1903 um consórcio de exportadores de café, que levantariam fundos com banqueiros europeus, para financiar a retenção de estoques, conter a queda nos preços e promover a valorização do produto. Adotada pelo governo de São Paulo, essa proposta se materializaria no chamado Convênio de Taubaté. Casou-se com Laura de Melo Coelho, membro de uma importante família da aristocracia paulista.

Seu mausoléu, construído pelo escultor Amadeu Zani, possui alegorias assíriobabilônicas, com umafigura feminina sobreposta ao portal da capela, provavelmente a mais sombria das esculturas do Cemitério, a figuração de uma mulher em profunda dor (Serviço Funerário de São Paulo, 2010a).Externamente é constituído por mármore, com a base de apoio constituída por granito vermelho, apresentando escultura em bronze de uma guirlanda. Internamente possui um altar em mármore, que comporta um busto feminino também do mesmo material. Parte da parede é revestida por outro tipo de mármore, identificado visualmente como Mármore Nero Portono. A parte superior da parede apresenta várias pinturas, incluindo o teto que representa um céu estrelado.

As Figuras 180 e 181 aludem ao dia do enterro do Conde, que segundo a Revista $A$ Cigarra, paralisou São Paulo. A Figura 180 mostra a entrada do caixão do Conde no Cemitério da Consolação, apresentado o bispo Dom Duarte de Leopoldo e Silva a frente do Cortejo. A Figura 181 retrata o momento do sepultamento do Conde. 


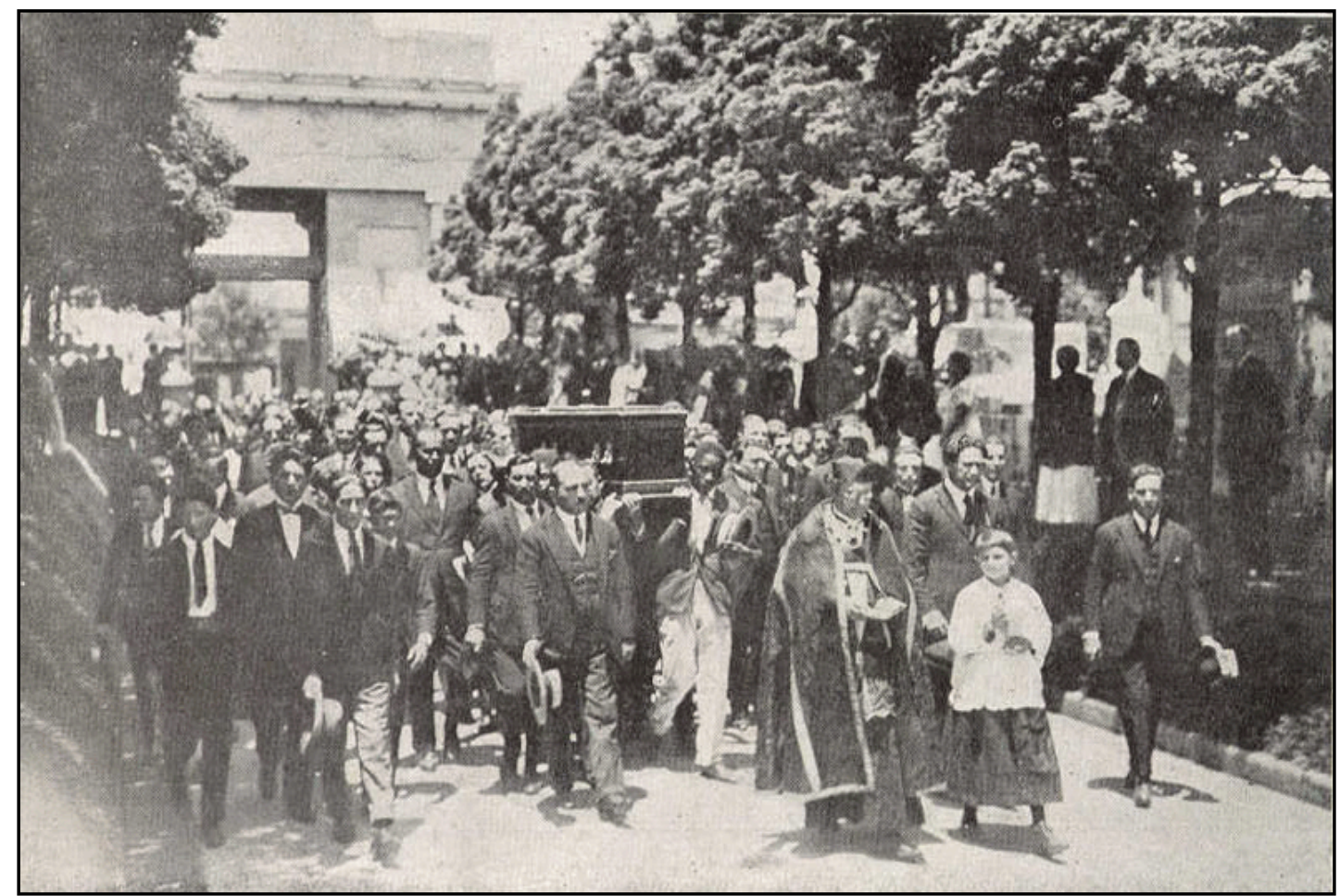

Figura 180. Fotografia da entrada do cortejo fúnebre do Conde Alexandre Siciliano, no Cemitério da Consolação, em 1923.

Fonte: Revista A Cigarra, edição de 15 de fevereiro e 1 de março de 1923.

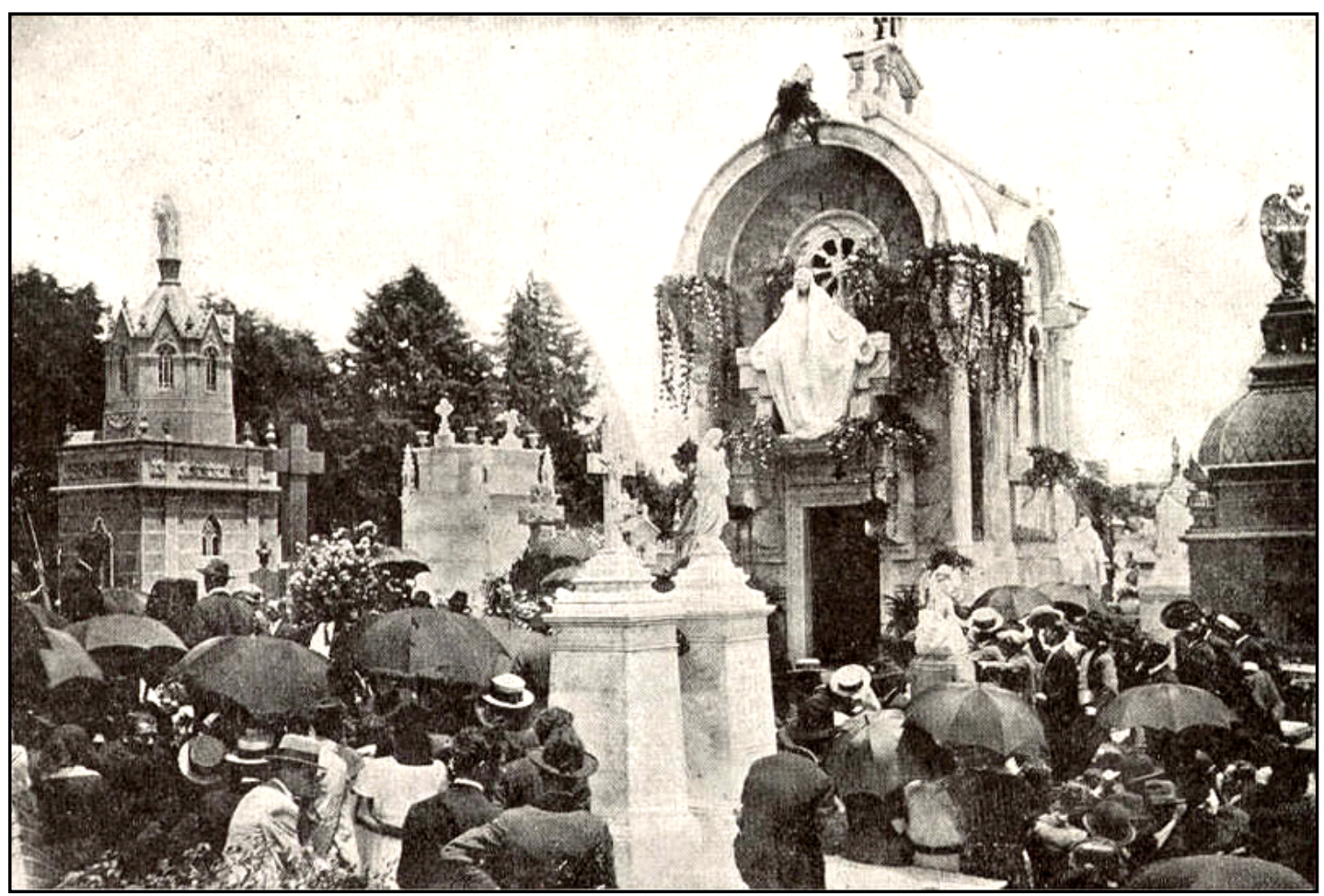

Figura 181. Fotografia do sepultamento do Conde Alexandre Siciliano no Cemitério da Consolação, em 1923.

Fonte: Revista A Cigarra, edição de 15 de fevereiro e 1 de março de 1923. 
A evolução do estado de conservação do mausoléu com o tempo pode ser acompanhado pelas Figuras 182 a 184.

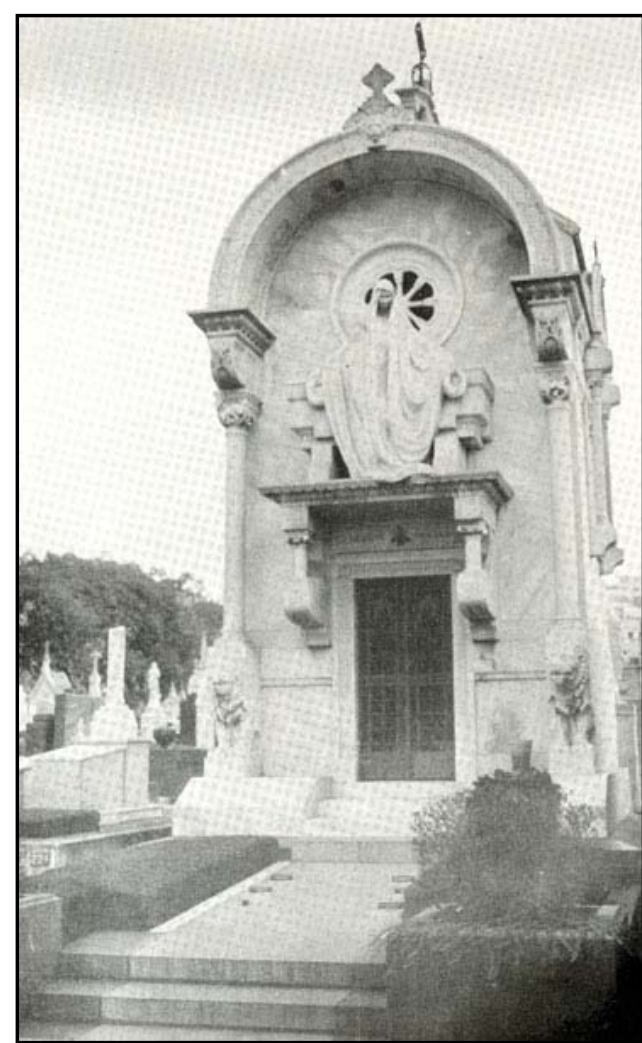

Figura 182. Túmulo do Conde Siciliano na década de 1970.

Fonte: Valadares, 1972.

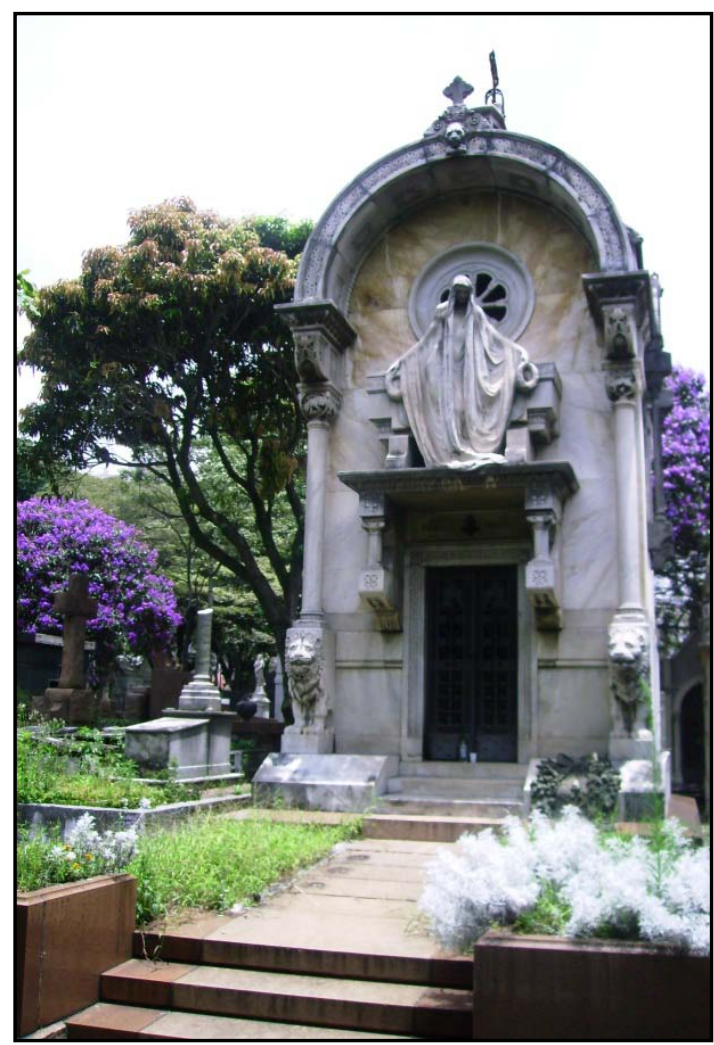

Figura 183. Túmulo do Conde Sicialiano em 22 de janeiro de 2009.

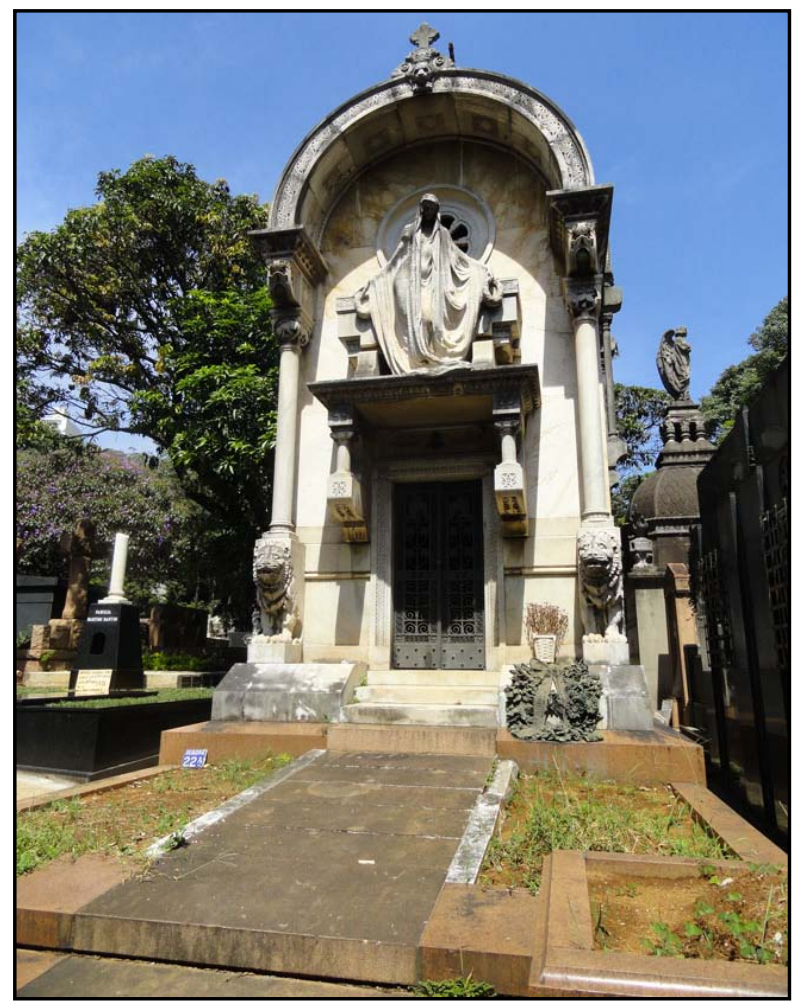

Figura 184. Túmulo do Conde Sicialiano em 08 de março de 2013. 
A Figura 182 retrata o mausoléu na década de 1970, apresentando ornamentação retangular sob a base de sustentação do mausoléu, além de argolas na parte central. Apesar de a fotografia ser em tons de cinza, nota-se que a parte inferior do túmulo, próxima a porta de entrada, apresenta tonalidade homogênea, sem indícios de locais escurecidos. A Figura 183 mostra o jazigo em 2009, já bastante deteriorado, retratando a ausência das argolas e da ornamentação retangular, além de evidenciar a sujidade nas partes inferiores do mausoléu, tanto no mármore como no granito. A Figura 184 retratao atual estado de conservação do mausoléu (Março de 2013), com a ausência dos jardins, e aumento da sujidade e alteração cromática.

Muitas outras formas de deterioração foram mapeadas, a Figura 185 retrata sujidade na parede lateral inferior do mausoléu. A Figura 186 evidencia a alteração cromática do mármore (amarelamento) e a presença de uma colmeia. As Figuras 187 a 190correspondem à parte interior do jazigo, estando bastante degradado. A Figura 187 retrata alteração cromática do altar, busto e revestimento das paredes, todos em mármore, e a Figura 188 evidencia a falta de limpeza. As Figuras 189 e 190 retratam as paredes superiores e o teto do jazigo, com intensa degradação das pinturas devido à umidade. A Figura 191mostraapresença de crosta negra na parte externa e superior do jazigo, e erosão diferencial da estátua, com a Figura 192 evidenciando a crosta negra. A Figura 193 mostra em detalhe a sujidade e a ausência das argolas na base de sustentação em granito, e a Figura 194 evidencia o grafite existente próximo à porta de acesso.

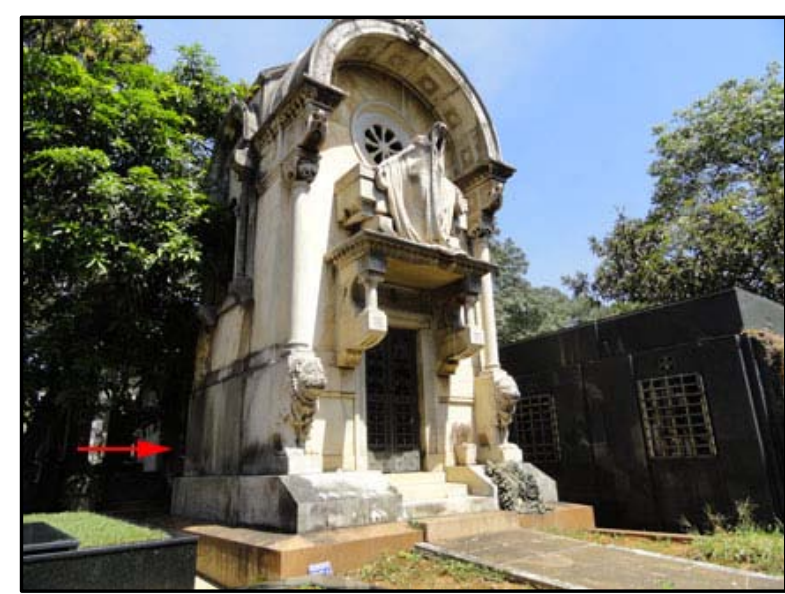

Figura 185. Sujidade na parede lateral inferior do mausoléu em mármore.

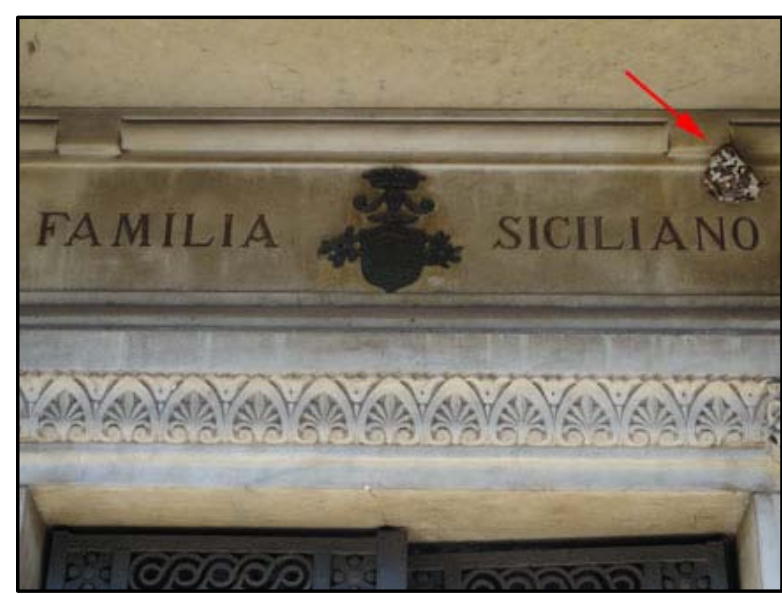

Figura 186. Alteração cromática do mármore (amarelamento) e a presença de uma colmeia (seta vermelha). 


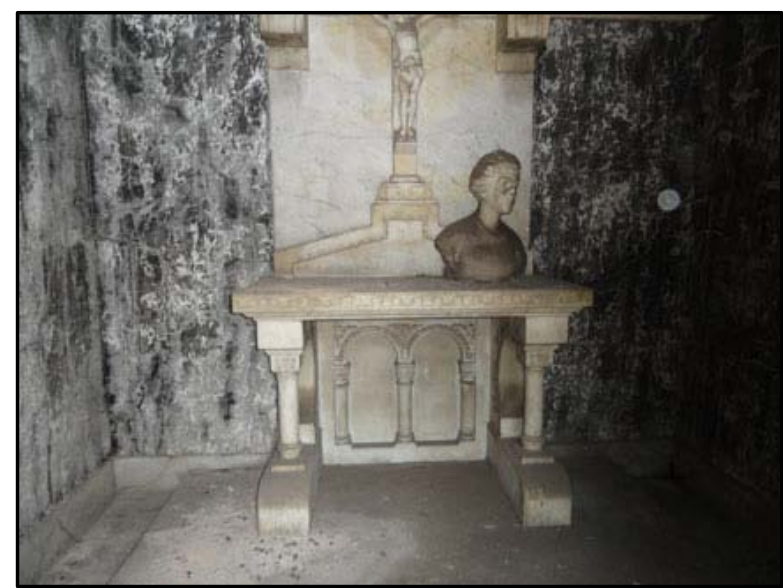

Figura 187. Alteração cromática do altar, busto e revestimento em mármore.

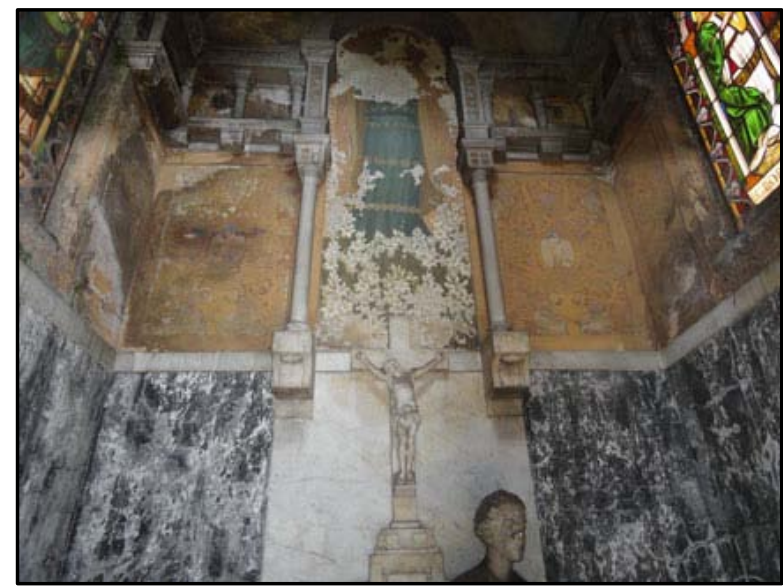

Figura 189. Degradação das pinturas existentes nas paredes.

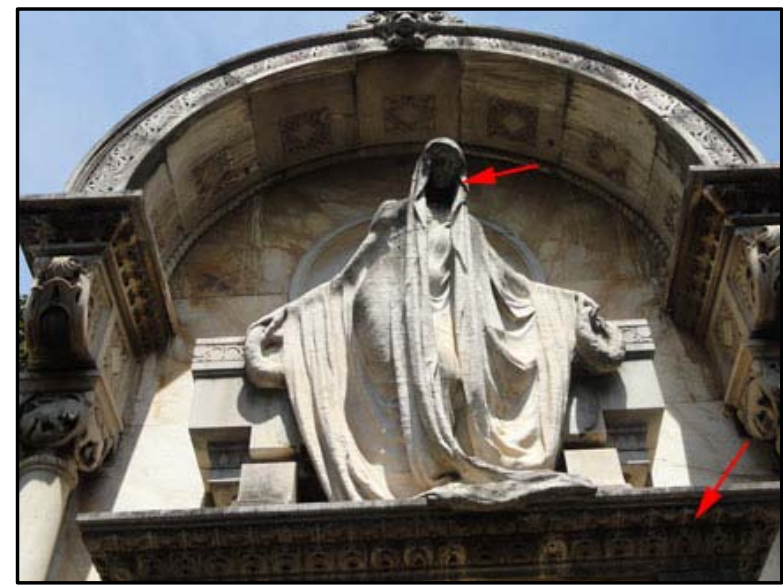

Figura 191. Setas indicando locais com crosta negra.

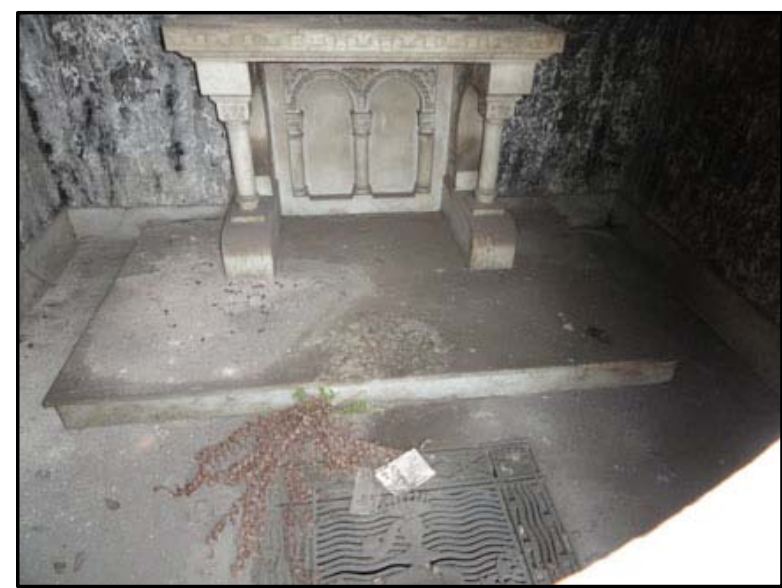

Figura 188. Falta de limpeza do mausoléu.

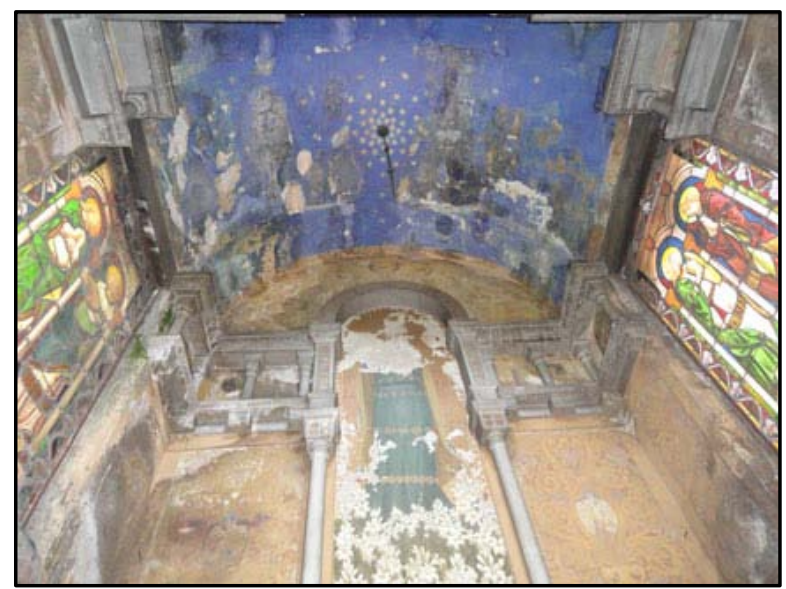

Figura 190. Degradação das pinturas existentes no teto.

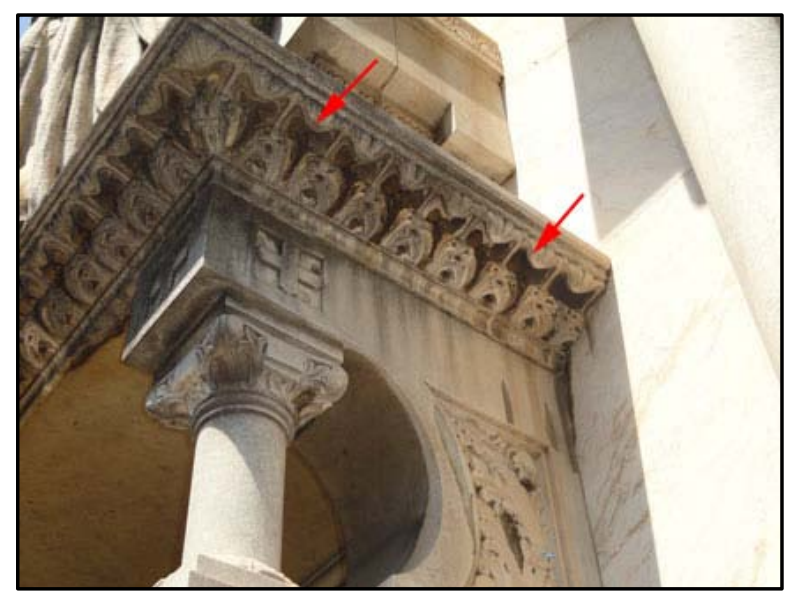

Figura 192. Setas indicando locais com crosta negra. 


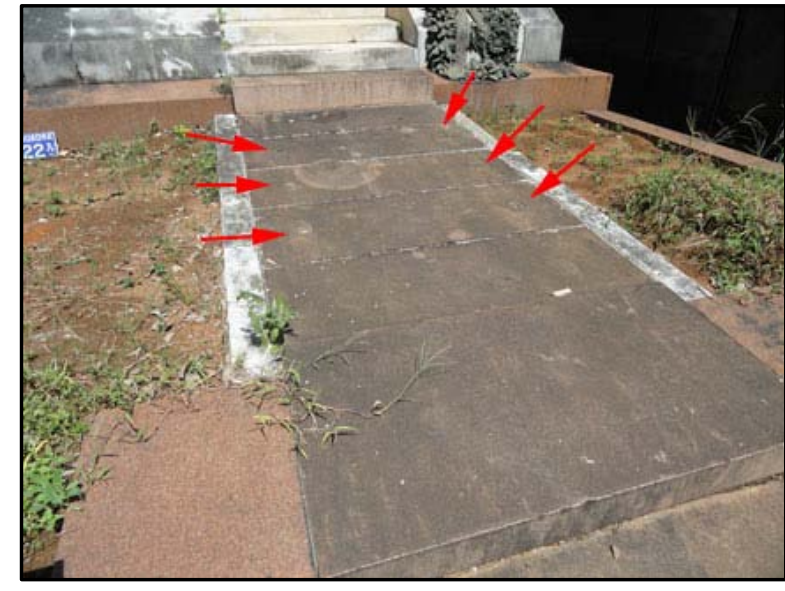

Figura 193. Base de sustentação, em granito, com sujidade e setas indicando a ausência das argolas.

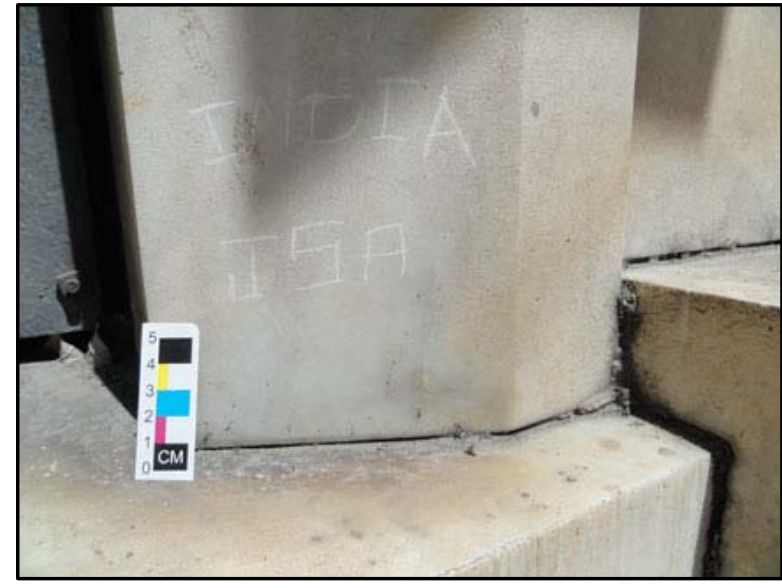

Figura 194. Grafite próximo a porta de acesso.

\subsection{MÉTODOS INADEQUADOS DE CONSERVAÇÃO E RESTAURO}

Qualquer intervenção a ser realizada em monumentos históricos deve ser muito bem planejada. Os condicionantes do processo de degradação devem ser determinados e as soluções encontradas para o problema devem ser testadas em laboratório ou em locais pouco visíveisdo monumento, considerando que os testes não afetem a sua integridade ou leitura. Vale lembrar que restauração ou métodos de conservação periódica devem seguir os princípios básicos da teoria da conservação, sem a criação de falsos artísticos e modificações domonumento que levem a condições que nunca existiram. A substituição de materiais deve serevitada, salvo em casos em que a deterioração da rocha afete a estrutura como um todo. Se a substituição é necessária, deve ser realizada somente no local com problemas, com material levemente diferente, sendo possível a sua distinção do original, mas que não afete a leitura estética da obra. Bens tombados não podem ser reparados, pintados ou restaurados sem prévia autorização especial pelo órgão de conservação responsável pelo monumento, sob pena de multa de $50 \%$ do valor do objeto (Cangussu e Cabral, 2012). É importante frisar que se os bens forem pertencentes à União, aos Estados ou aos municípios, a autoridade responsável pela destruição, mutilação ou demolição do bem tombado incorrerá pessoalmente na multa.

No caso do Cemitério da Consolação, notam-se alguns casos de restaurações bastante agressivas, que promoveram grande descaracterização dos túmulos. Nas situações que serão abordadaspercebe-se a total falta de estudos prévios, conhecimento dos princípios básicos da teoria da conservação e falta de capacidade e discernimento da empreiteira ou pessoa que realizou a obra.

O túmulo de Cerqueira César é constituído por vários tipos de materiais, ornamentação em bronze, granito vermelho que constitui a base de sustentação do túmulo, Granito 
Itaquera que constitui a parte superior do túmulo e mármore, utilizado na confecção de um anjo. Os principais problemas relacionados ao túmulo eram a alteração cromática promovida pela lixiviação do zinabre proveniente da ornamentação em bronze, depósitos de fuligem e colonização biológica. Após a limpeza notou-se o clareamento excessivo do granito vermelho, com a eliminação praticamente completa da alteração cromática, depósitos e colonização biológica (Figuras 195 e 196). Não se sabe o método utilizado na limpeza, entretanto deve ter-se empregado algo abrasivo. O anjo em mármore foi o mais prejudicado pela limpeza. A provável aplicação de produtos químicos contendo ácido promoveu o branqueamento excessivo da rocha, conduzindo-a a uma tonalidade inexistente para esse tipo litológico, além de suavizar os detalhes artísticos da estátua (Figuras 197 e 198). No caso do anjo, o que temos agora não é mais a obra original, mas sim a volumetria original descaracterizada pela modificação da cor da rocha e pelaperda dos detalhes originais da estátua.

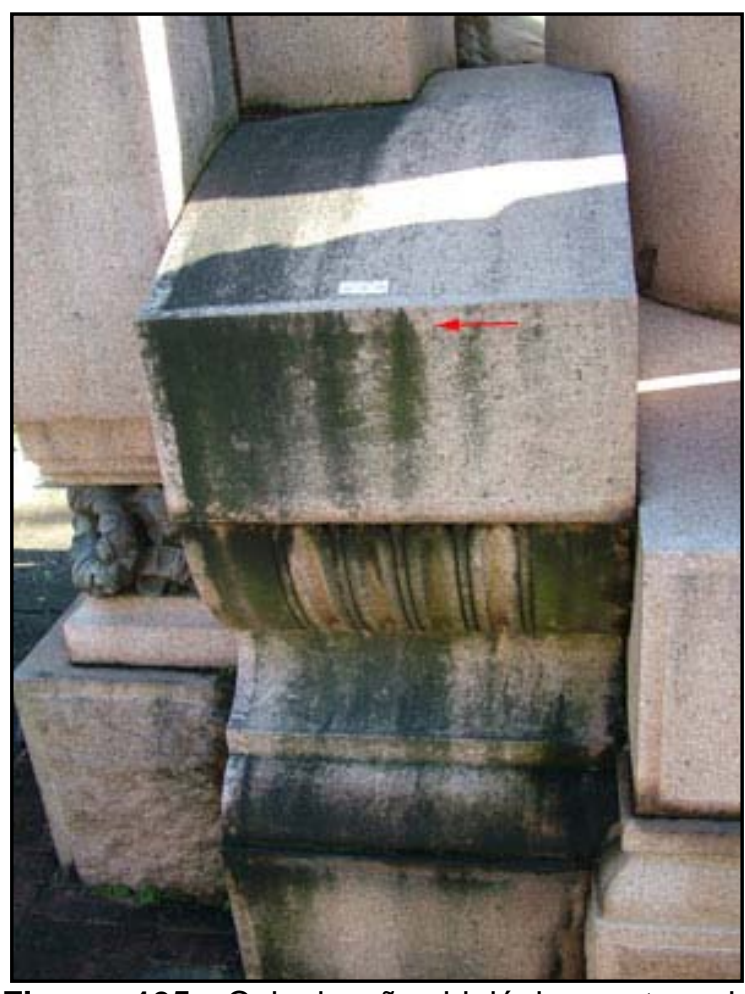

Figura 195. Colonização biológica antes da limpeza.

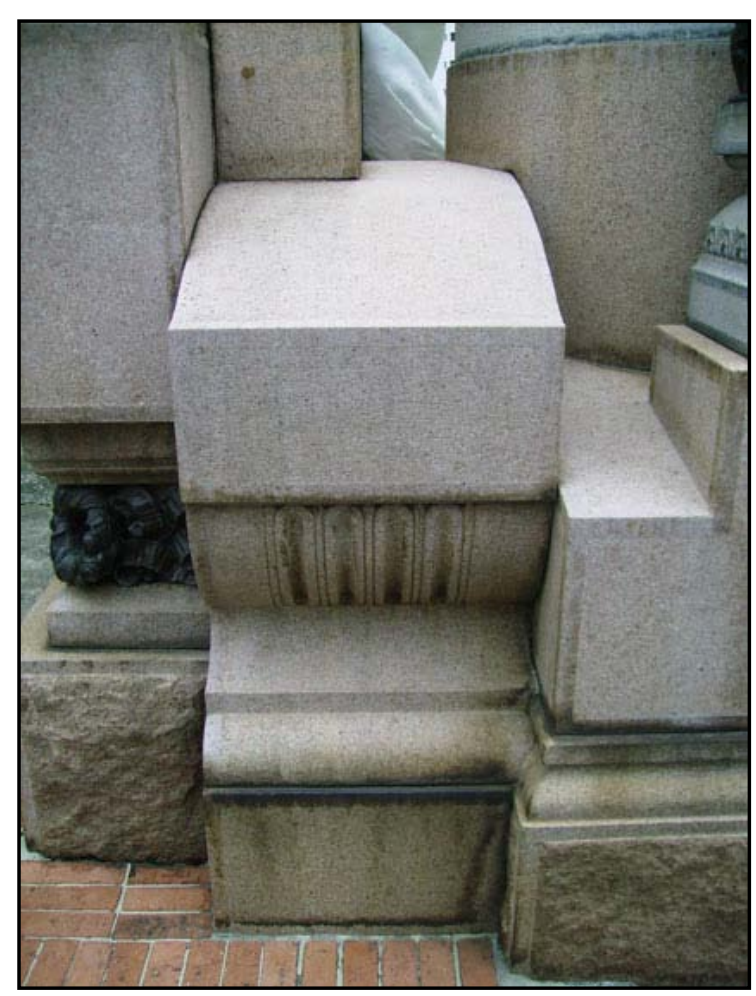

Figura 196. Ausência de colonização biológica após a limpeza e excessivo clareamento da rocha. 


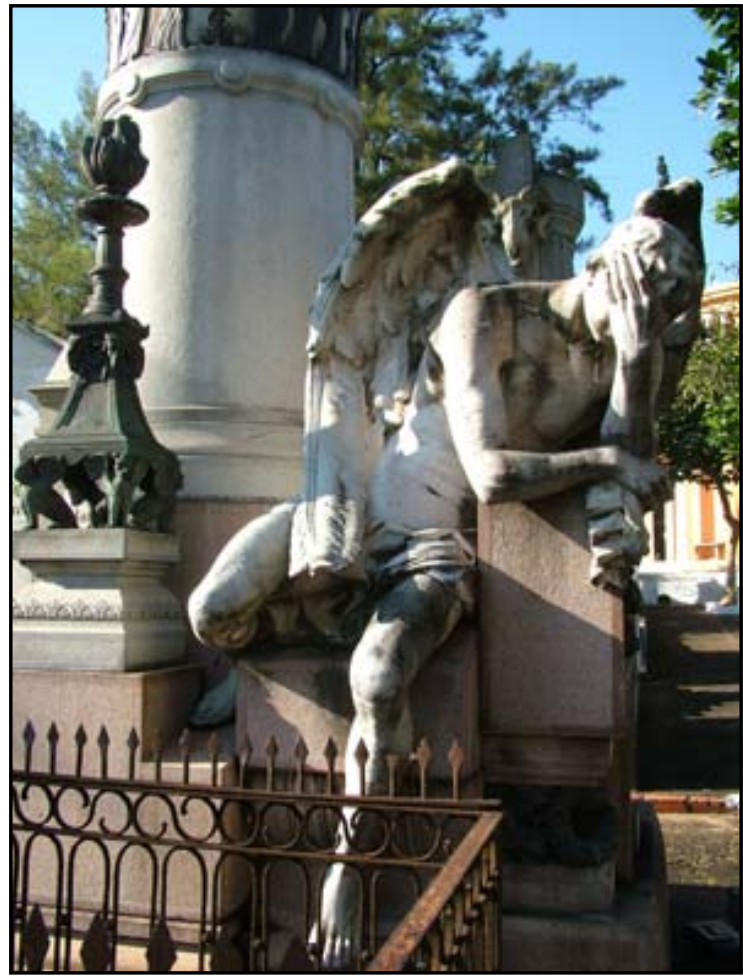

Figura 197. Notar os depósitos superficiais no anjo (partes escuras) antes da limpeza.

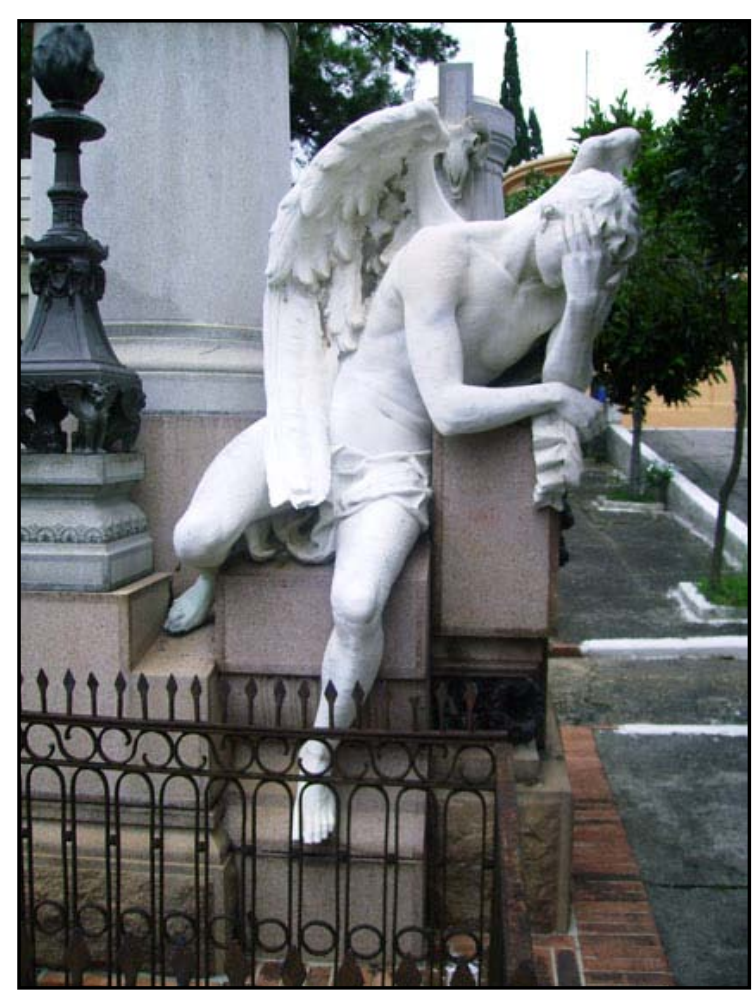

Figura 198. Notar a ausência dos depósitos superficiais no anjo após a limpeza e excessivo branqueamento.

Outro caso de descaracterização do túmulo após a restauração é o da Família Pila (Figuras 199 a 201). Construído pela década de 1930, é constituído por dois tipos de mármore, um cinza utilizado na parte inferior do jazigo, e o outro branco, correspondente ao mesmo litotipo utilizada nos túmulos mais antigos do cemitério, que perfaz toda a estrutura do jazigo. Desconhece-se o estado de conservação antes da restauração, entretanto notase a completa descaracterização do túmulo. Na Figura 199, a seta indica a substituição do mármore antigo por um mármore novo. No caso da tampa do túmulo a nova rocha foi fixada por cima da antiga. A ornamentação existente foi mantida, entretanto nota-se a aplicação de algum produto para clareamento da rocha, assim como a aplicação de parafusos para fixação das partes que compõe o vaso (Figura 201). A inscrição no vaso aparentemente foi refeita. 


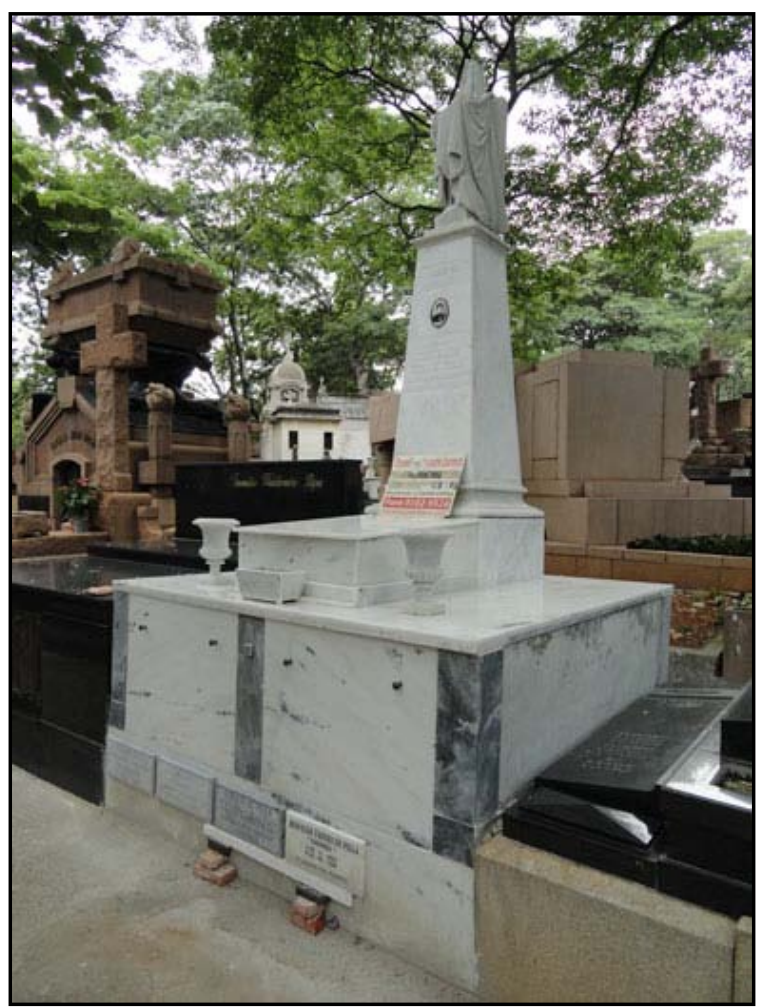

Figura 200. Túmulo da Família Pilla.

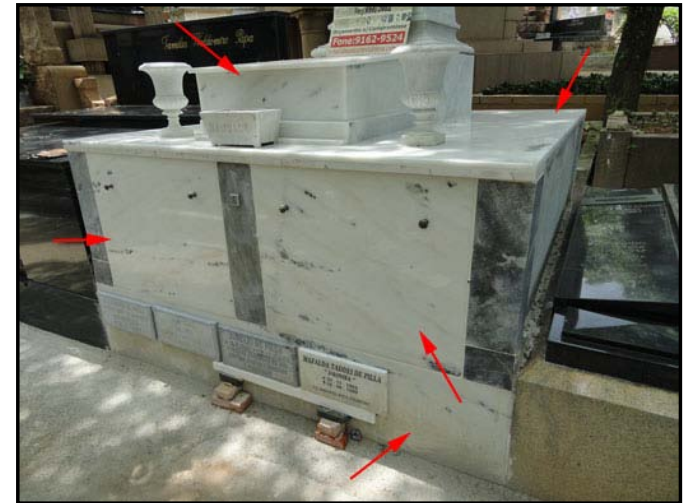

Figura 199. Setas indicam locais com substituição do mármore.

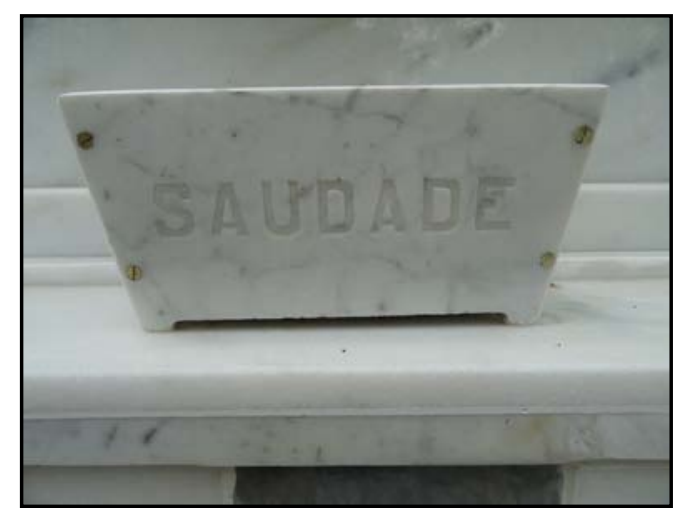

Figura 201. Aplicações de parafusos para a fixação das laterais do vaso.

Os jazigos da Marquesa de Santos e dos seus familiares, ao lado esquerdo, passaram por grandes modificações. Comparando-se as Figuras 202 e 203, nota-se no jazigo da Marquesa de Santos a ausência da ornamentação pontiaguda localizada na parte superior do túmulo, o acréscimo do jardim e a pintura da base da estrutura com tinta látex. Os túmulos dos seus familiares, antes separados, agora se apresentam unidos, também sendo parcialmente pintados com tinta látex

Em 2004, o falecido sanfonista Mário Zan concedeu entrevista ao Jornal Folha de S.Paulo (Anexo 5) e comentou a respeito do túmulo da Marquesa de Santos, a qual tinha extrema admiração:

Cheguei lá (ao jazigo da Marquesa), estava tudo em petição de miséria, tinha despacho de macumba, pichação, muito lixo e até um pé de milho! Mandei limpar tudo, reformar a lápide e pago uma pessoa para ir lá toda a semana conservar e trocar as flores.

Não se sabe se foi Mário Zan quem promoveu as modificações, entretanto considerando todas as manifestações que ocorreram na década de 1970 contra a desapropriação do jazigo da Marquesa, e sua posterior proteção por lei, tais modificações 
não poderiam ter ocorrido. Apesar de nos depararmos com um túmulo bem conservado nos dias de hoje, trata-se na verdade de um falso artístico, onde até mesmo a cor da rocha foi modificada pelas constantes limpezas empregando-seprodutos químicos. Nesse caso tanto o abandono como a intervenção excessivaprejudicam o jazigo.

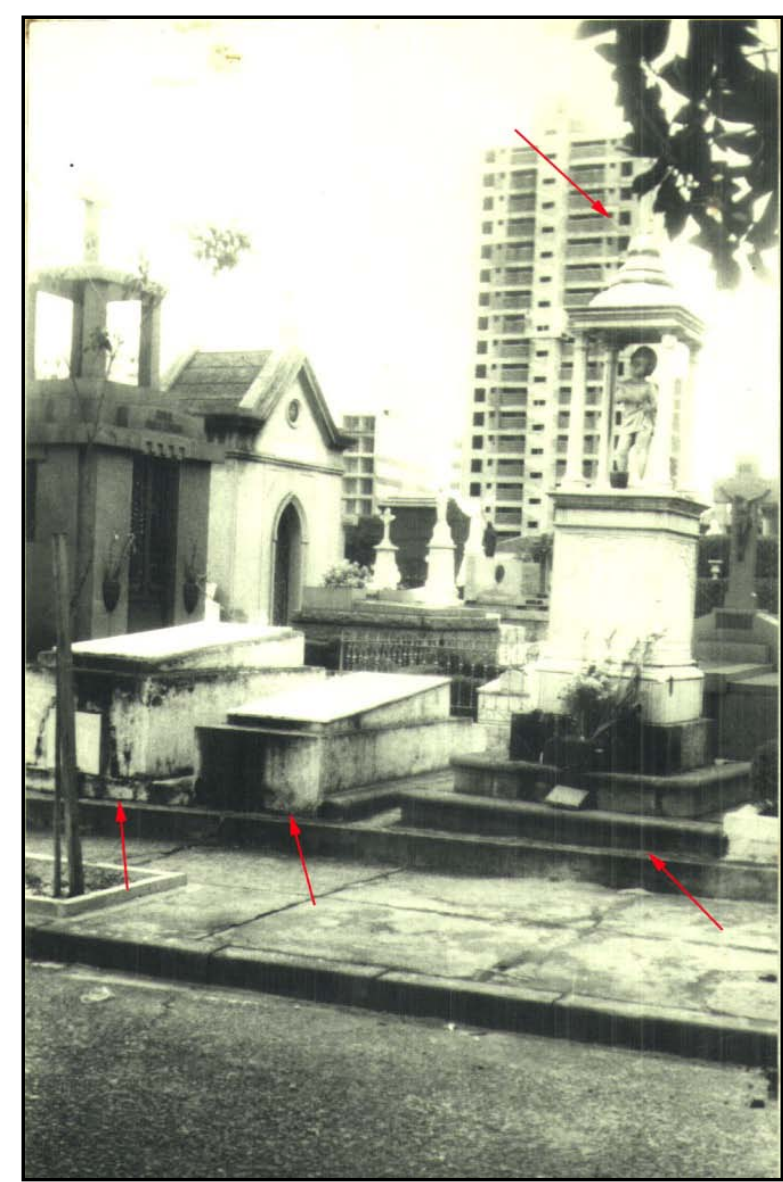

Figura 202. Fotografia do túmulo da Marquesa de Santos em 1969. As setas indicam os locais antes da pintura com tinta látex.

Fonte: Arquivo de Tombamento do Cemitério no CONDEPHAAT.

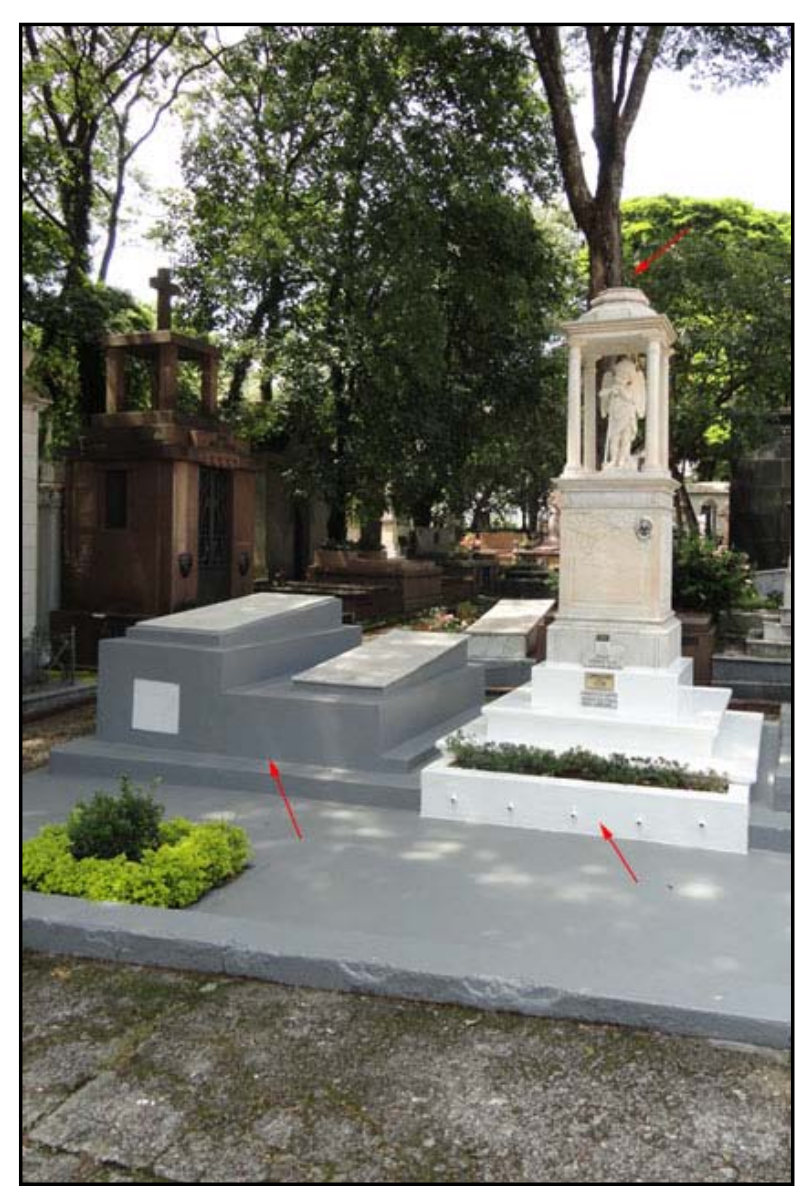

Figura 203. Fotografia do túmulo da Marquesa de Santos em 2013. As setas indicam os locais que foram pintados com a tinta látex.

O uso de cimento como material de restauro foi muito utilizado no passado, entretanto notou-se com o tempo os graves danos que esse material proporcionava as rochas, principalmente devido a geração de sais expansíveis. As Figuras 204 e 205 mostram a utilização desse material no cemitério. No primeiro caso, a tampa de mármore provavelmente colapsou após a abertura do jazigo, preferindo-se a vedação após o sepultamento, com a utilização de tijolos e cimento. No segundo exemplo o material foi utilizado para colar a escultura. Em ambos os casos nota-se a total falta de cuidado na aplicação, já incorreta, do material. A Figura 206 retrata uma prática utilizada em algumas estátuas e jazigos, a pintura com látex, que promove total descaracterização da rocha. 


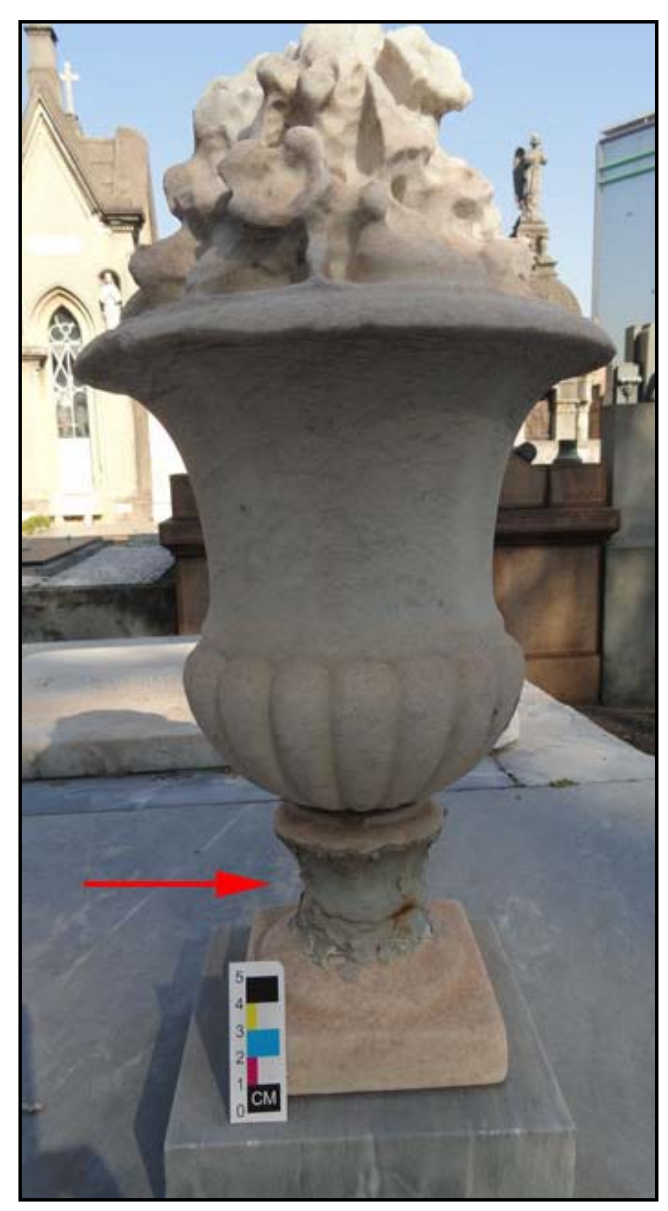

Figura 205. Escultura em mármore colada com cimento.

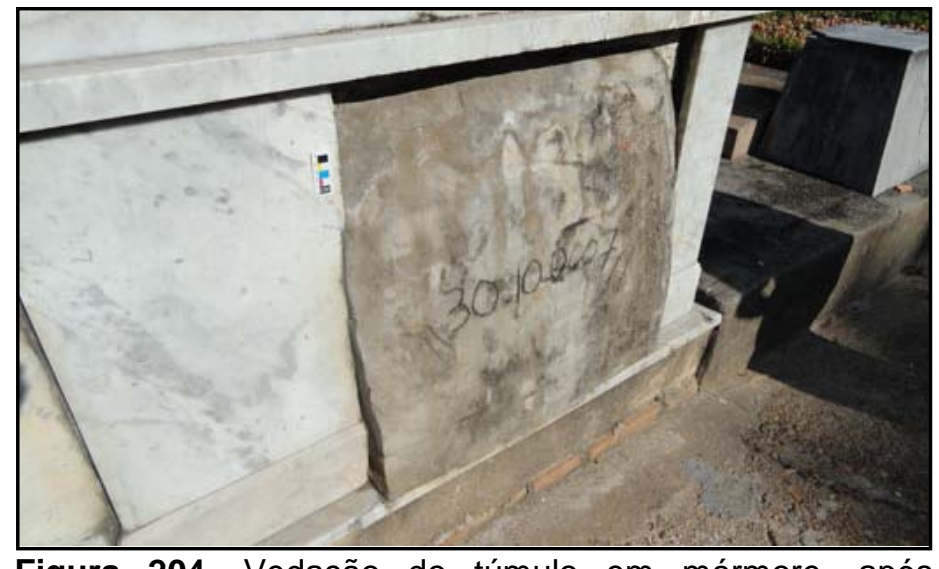

Figura 204. Vedação do túmulo em mármore, após sepultamento, com tijolos e cimento.

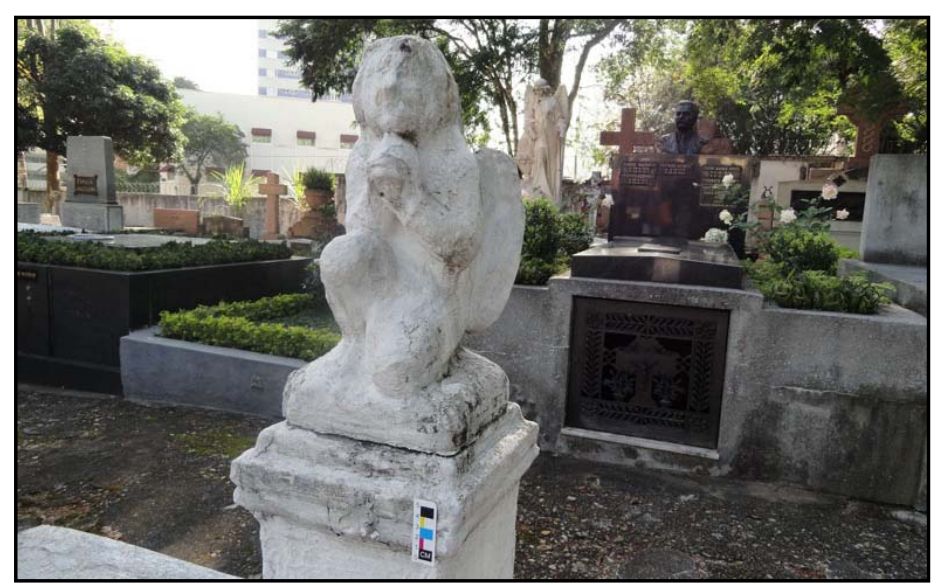

Figura 206. Pintura da estátua de mármore com látex.

\section{AÇÕES DE CONSERVAÇÃO}

Em muitos países existem projetos de grande importância sobre cemitérios em diversas áreas do conhecimento. A Association for Gravestone Studies, sediada em Massachusetts, EUA, foi fundada em 1977 com a finalidade de promover a preservação de túmulos. Através de publicações, conferências, oficinas e exibições, promove o estudo das necrópoles nas perspectivas histórica e artística, expande a consciência pública da sua importância e incentiva indivíduos e grupos a estudá-las e preservá-las. Maxwell et al. (2001) abordam os cemitérios históricos, fornecendo um guia com recomendações sobre a identificação das lápides em risco, a reparação de jazigos e monumentos, e orientações sobre a prioridade de reparo. Utilizando exemplos da Escócia, apresentam seis estudos de caso e um checklist de boas práticas.

Nos Estados Unidos, muitos estados possuem organizações ligadas à divulgação e conservação dos seus cemitérios históricos. Por meio de publicações, que englobam guias 
de preservação, difundem a importância da preservação da necrópole para a sociedade, além de divulgar métodos básicos de preservação dos túmulos, respeitando os princípios da teoria da conservação. Para cemitérios dos EUA destacam-se os seguintes guias de conservação: King (2004), Hassen e Cobb (2008), Alabama Historical Commission (2009), Massachusetts Department of Conservation and Recreation (2009), Texas Historical Commission (2011). A Austrália e a Nova Zelândia também possuem guias para a prática de preservação dos seus cemitérios são eles: Opus International Consultants Limited (2005) e National Trust of Australia (2008). Na França, um guia de bolso é entregue as pessoas que possuem jazigos nos cemitérios, indicando os principais materiais utilizados nos túmulos, principais formas de degradação, e o que pode e não pode ser utilizado em uma limpeza periódica (Anexo6).

No caso do Cemitério da Consolação, além do seu tombamento, que na teoria constitui uma medida de preservação, a divulgação do seu acervo cultural constitui a única forma de conservação existente. Visitas monitoradas pelos principais túmulos de importância histórica e artística são realizadas, necessitando agendamento prévio com a Assessoria de Imprensa do Serviço Funerário de São Paulo. Na necrópole são disponibilizadas duas publicações: uma divulga a história do cemitério e de alguns importantes túmulos existentes no seu interior (Serviço Funerário de São Paulo, 2010a) e a outra se trata de um guia de visitação (Serviço Funerário de São Paulo, 2010b), presente no Anexo 7. Além dos mecanismos de conservação citados, não existe qualquer trabalho desenvolvido pelo órgão de conservação ou pelo Serviço Funerário de São Paulo a respeito da conservação e preservação do cemitério aos olhos dos principais básicos da teoria da conservação.

\section{CONCLUSÕES}

Os problemas de conservação expostos evidenciam a necessidade de políticas de preservação eficientes no Cemitério da Consolação. Essas medidas devem focar nos conceitos teóricos da conservação, ajudando a desenvolver o discernimento de quais tipos de intervenções são justificáveis, e quando necessárias, que os métodos empregados sejam criteriosos e aplicados com bom senso. Cabe enfatizar a qualquer instituição ou cidadão que venha a intervir na necrópole, que se está diante de um dos mais completos acervos culturais da cidade de São Paulo. Práticas inadequadas, mesmo que mínimas, podem levar a perda de informações importantíssimas em várias esferas do conhecimento. A necrópole já possui a intempérie como inimiga, métodos inadequados e desnecessários tendem a acelerar os processos de deterioração.

Em muitos cemitérios da Europa, a exemplo do Cemitério Acatólico de Roma, é comum a contratação de profissionais ligados à área patrimonial para gestão 
conservacionista adequada desses espaços. Esses profissionais determinam quando uma intervenção deve ser realizada e quais métodos devem ser utilizados, além de acompanhar a evolução do estado de conservação dos túmulos com o tempo. Infelizmente no Brasil a gestão patrimonial é inexistente, o que acontece geralmente é a contratação de empresas para casos relacionados diretamente a necessidade de intervenção. Poucos monumentos possuem uma manutenção periódica e preventiva.

O aproveitamento turístico do cemitério deve ser expandido, pois é um dos principais mecanismos de proteção existentes no Brasil. Os monumentos mais visitados geralmente são os mais conservados, respeitados e vigiados. Enquanto o preconceito tende a levar a necrópole ao abandono e descaso, o conhecimento pode ajudar, por exemplo, na diminuição dos atos de vandalismos, tanto pelo aumento do policiamento como pela conscientização do ato hediondo que é agredir o patrimônio cultural.

A metodologia utilizada mostrou-se adequada, proporcionando resultados satisfatórios para a determinação do estado de conservação de monumentos pétreos, entretanto tanto o ultrassom como o espectrofotômetro ainda necessitam de estudos metodológicos aprofundados, para melhorar a interpretação dos dados e o aproveitamento dos equipamentos.

Por fim, a conservação do Cemitério da Consolação não deve representar um problema, mas sim um desafio, que busca principalmente a preservação da identidade, ainda que não definida, do que é ser paulista, do que é ser brasileiro. 


\section{REFERÊNCIAS BIBLIOGRÁFICAS}

Alabama Historical Commission. 2009. Alabama's Historic Cemeteries: A Basic Guide to Preservation. 11p. Disponivel em: $<$ http://preserveala.org/pdfs/sites/Alabama's\%20Historic\%20Cemeteries_A\%20Basic\% 20Guide\%20to\%20Preservation.pdf>. Acessado em: 1 de março de 2013.

Almesberger, D., Geometrante, R., Rizzo, A. 2000. UltrasonicTestingMethod for theCharacterizationofPietra D'IstriaStructuralElements.In: 9th International Congress on Deterioration and Conservation of Stone. Veneza.Volume II. p. 317-325.

American Society for Testing and Materials (ASTM), D 2845-00, 2000, Standard test method forlaboratory determination of pulse velocities and ultrasonic elastic constants of rock, EstadosUnidos.

Andrade M.C., Santos S.F., Barbato C.N., Sampaio J.A., Da Luz A.B., Silva F.T., Ogasawara T. 2005. Insumos Cerâmicos para Porcelanas. XXI Encontro Nacional de Tratamento de Minérios e Metalurgia Extrativa. Vol. 2, p. 401-408.

Araújo T.N.de. 2006. Túmulos celebrativos de Porto Alegre:múltiplos olhares sobre o espaço cemiterial (1889-1930). Porto Alegre: PUCRS. Dissertação de Mestrado. 96p.

Associação Brasileira da Indústria de Rochas Ornamentais - ABIROCHAS. Catálogo Brasileiro de Rochas Ornamentais. Disponível em: $<$ http://www.abirochas.com.br/catalogo1.php>. Acessado em: 01 de novembro de 2012.

Associação Brasileira de Normas Técnicas (ABNT), NBR 8802. 1994. Concreto endurecido - Determinação da velocidade de propagação de onda ultra-sônica, Rio de Janeiro.

Atayde C.M., Gonçalez J.C., Camargos J.A. 2011. Características colorimétricas entre as seções anatômicas da madeira de muirapiranga (Brosimum sp.). Cerne. Vol. 17, p. 231-235. 
Autran C.daS., Gonçales J.C. 2006. Caracterização colorimétrica das madeiras de muirapiranga (Brosimum rubescens Taub.) e de seringueira (Hevea brasiliensis, clone Tjir 16 Müll Arg.) visando à utilização em interiores. Ciência Florestal, Santa Maria. Vol. 16 , n. $3 / 4$, p. $445-451$.

Bedrikow R. 2001. Manoel de Abreu. J. Pneumologia. vol.27, n.1, p. 52-55.

Begonha A. 1997. Meteorização do granito e deterioração da pedra em monumentos e edifícios da cidade do Porto. Tese de Doutorado. Univ. Minho, Braga, 408p.

Bellomo H.R. 2000. Cemitérios do Rio Grande do Sul: arte, sociedade, ideologia. Porto Alegre: EDIPUCRS. 281p.

Blecher N. 2004. O maior do Brasil, um dos maiores do mundo. Revista Exame. Ed. 829. Disponível em: <http://exame.abril.com.br/revista-exame/edicoes/0829/noticias/omaior-do-brasil-um-dos-maiores-do-mundo-m0051565>. Acesso em: 1 de março de 2013.

Boito C. 1884. I restauratori: conferenza tenuta all'Esposizione di Torino il 7 giugno 1884. In: Boito C. 2002. Os Restauradores. São Paulo: Ateliê. 64p.

Botelho M.R., Dalmolin R.S.D., Pedron F.deA., Azevedo A.C.de, Rodrigues R.B., Miguel P. 2006. Medida da cor em solos do Rio Grande do Sul com a carta de Munsell e por colorimetria. Ciência Rural. Vol. 36, p. 1179-1185.

Brasil - Presidência da República. 1998. Lei № 9.605 de 12 de fevereiro de 1998. Disponível em: <http://www.planalto.gov.br/ccivil_03/leis/L9605.htm>. Acessado em: 1 de março de 2012.

Burgess F. 2004. English Churchyard Memorials. Cambridge: The Lutterworth Press. 326p.

Cangussu D.D.D., Cabral B.F. 2012. Análise dos atuais mecanismos de proteção do patrimônio histórico, cultural, artístico, turístico e paisagístico nacional. Jus Navigandi, Teresina, ano 17, n. 3166. Disponível em: <http://jus.com.br/revista/texto/21215>. Acesso em: 1 de março de 2013. 
Carone E. 2001. A Evolução Industrial de São Paulo (1889-1930). Editora SENAC São Paulo. 198p.

Carvalho M.C.W.de. 2000. Ramos de Azevedo. São Paulo. EDUSP. 406p.

CETESB. 2012. Qualidade do $\mathrm{Ar}$ no Estado de São Paulo. Disponível em:<http://www.cidadessustentaveis.org.br/sites/default/files/noticias/relatorio-ar2012.pdf>. Acessado em: 4 de junho de 2013.

Chung H. W., Law K. S. 1983 Diagnosing in situ concrete by ultrasonic pulse technique. Concrete International.Outubro.p. 42-49.

Costa D., Delgado Rodrigues J. 1996. Assessment of colour changes due to treatmentproducts in heterochromatic stones. In: Conservation of granitic rocks. J. DelgadoRodrigues and D. Costa (Eds.) Lisboa, LNEC, p. 95-101.

Daniels C. 2006. Graveyard Memorials. In: Henry A. (ed.). Stone Conservation - Principles and Practice. United Kingdom: Donhead. p. 299-326.

Delgado Rodrigues J., Costa D. 1996. Assessment of the harmfulness of consolidants in granites. In: Conservation of granitic rocks. J. DelgadoRodrigues and D. Costa (Eds.) Lisboa, LNEC, p. 71-78.

Della V.P., Junkes J.A., Rambo C.R., Hotza D. 2008. Síntese do pigmento cerâmico verde vitória (Ca3Cr2Si3O12) a partir de $\mathrm{CaCO}_{3}, \mathrm{Cr}_{2} \mathrm{O}_{3}$ e $\mathrm{SiO}_{2}$. Química Nova. Vol. 31, n.5, p. 1004-1007.

Del Lama E.A., Szabó G.A.J., Dehira L.K., Kihara Y.2008. Impacto do intemperismo no arenito derevestimento do Teatro Municipal de São Paulo. Geologia USP, Série Cientifica. Vol.8, n.1, p. 75-86.

Del Lama E.A., Dehira L.K., Reys A.C.dos. 2009. Visão Geológica dos Monumentosda Cidade de São Paulo. Revista Brasileira de Geociências. Vol. 39, n.33, p. 409-420. 
Dionísio A., Aires-Barros L., Bastos M.J. 2004. A degradação das rochas do patrimônio cultural construído: o caso das rochas carbonatadas. Boletim da Soc. Portuguesa de Química, vol. 93, p. 61-68.

Doehne E., Price C. A. 2010. Stone Conservation: an overview of current research. Research in Conservation. The Getty Conservation Institute.Los Angeles. 158p.

Durán-Suárez J.A., García-Beltrán A., Sáez-Pérez M.P., Rodríguez-Gordillo J. 2000. Evaluation of the chromatic effectiveness of color pigments in restoration materials (lime and Portland cement). Color: Research and Applications Journal. Vol.25, n.4,p. 286-291.

European Cemeteries Route. 2010. Association of Significant Cemeteries in Europe.Disponível em: http://www.cemeteriesroute.eu/1ED756EB-C5B4-4ED4-95B28B72CF452270/FinalDownload/DownloadldB07A9FEABE9697EA40935619D4C34E60/1ED756EB-C5B4-4ED4-95B28B72CF452270/en/wp-content/uploads/CemeteriesRouteGuide.pdf. Acessado em: 4 de junho de 2013.

Evangelista A. C. J. 2002. Avaliação da Resistência do Concreto Usando Diferentes Ensaios Não Destrutivos. Tese de Doutorado, Engenharia Civil, Universidade Federal do Rio de Janeiro. 239p.

Feliu M.J., Edreira M.C., Martín J.,Calleja S., Ortega P. 2005. Study of Various Interventions in the Façades of a Historical Building-Methodology Proposal, Chromatic and Material Analysis.Color: Research and Applications Journal. Vol.30, n.5, p. 382-390.

Ferreira Pinto A.P., Delgado Rodrigues J., Costa D. 1996a. Assessment of theefficacy and harmfulness of water repellents in granite. In: Conservation ofgranitic rocks. J. Delgado Rodrigues and D. Costa (Eds.) Lisboa, LNEC, p. 29-41.

Ferreira Pinto A.P., Delgado Rodrigues J., Costa D. 1996b. Behaviour of waterrepellents in granites under accelerated ageing tests. In: Conservation of graniticrocks. J. Delgado Rodrigues and D. Costa (Eds.) Lisboa, LNEC, p. 43-54. 
Fitzner B. 2004. Documentation and evaluation of stone damage on monuments. In: 10th International Congress on Deterioration and Conservation of Stone - Estocolmo. p. 667-690.

Fitzner B., Heinrichs K. 2004. Photo atlas of weathering forms on stone monuments. Geological Institute, RWTH Aachen University.Working Group "Natural Stones and Weathering".Disponível em: http://www.stone.rwth-aachen.de. Acessado em: 20 de junho de 2012.

Fitzner B., Heinrichs K., La Bouchardiere D. 2002. Limestone weathering of historical monuments in Cairo, Egypt. In: Siegesmund S., Weiss T., Vollbrecht A. Natural stone, weathering phenomena, conservation strategies and case studies. Geological Society of London, Special Publication, p. 217-239.

Fitzner B., Heinrichs K., La Bouchardiere D. 2003, Weathering damage on Pharaonic sandstone monuments in Luxor - Egypt.Building stone decay: observations, experiments and modeling, p. 1089-1103.

Fort R., Mingarro F., López de Azcona M.C., Rodriguez Blanco J. 2000.Chromatic parameters as performance indicators for stone cleaning techniques.Color Research \& Application. Vol. 25, p. 442-446.

Frascá, M.H.B.O. 2003. Estudos experimentais de alteração acelerada em rochas graníticas para revestimento. Tese (Doutorado) - Instituto de Geociências, Universidade de São Paulo, São Paulo, 264p.

Franceschi E.,Letardi P., Luciano G. 2006.Colour measurements on patinas and coating system for outdoor bronze monuments. Journal of Cultural Heritage. Vol. 7, n. 3, p. 166-170.

Furlan V., Girardet F. 1983. Considerations on the rate of accumulation and distribution of sulphorouspollutants in exposed stones. In:Wittmann F.H. Eds. Materials Science and Restoration. Lackund Chemie: Filderstadt, Germany,p. 285-290.

García-Talegon J., Vicente M.A., Vicente-Tavera S., Molina-Ballesteros E.1998. Assesment of chromatic changes due to artificial ageing and/or conservation treatments of sandstones.Color Research \& Application. Vol. 23, p. 46-51. 
Gimenez A. M. S. 2012. Avaliação do comportamento de ondas ultrassônicas no monumento às Bandeiras. Dissertação de Mestrado. Instituto de Geociências. Universidade de São Paulo. 73p.

Gomes C. de B. 2007. Geologia USP - 50 anos. São Paulo: Instituto de Geociências da USP, Edusp, 541p.

Gonçalez J.C., Janin G., Santoro A.C.S. Costa A.F., Vale A.T. 2001. Colorimetria quantitativa: uma técnica objetiva de determinar a cor da madeira. Brasil Florestal. Vol.20, n.72, p. 47-58.

Grimmer, A. E., ed. 1984. A Glossary of Historic Masonry Deterioration Problems andPreservation Treatments. Washington, DC: Dept. of the Interior, National Park Service, Preservation Assistance Division (US Government Printing Office).

Grossi C.M., Alonso F.J., Esbert R.M., Rojo A. 2007a. Effect of laser cleaning on granite color.Color Research and Application. Vol. 32, p. 152-159.

Grossi C.M., Brimblecombe P., Esbert R.M., Alonso F.J. 2007b. Colour changes in architectural limestones from pollution and cleaning. Color Research and Application. Vol.32, p. 320-331.

Grossi D. 2013. Análise do estado de conservação do Monumento a Ramos de Azevedo com utilização de métodos não destrutivos. Dissertação de Mestrado. Instituto de Geociências. Universidade de São Paulo. 136p.

Hassen H., Cobb D. 2008. Illinois Historic Cemetery Preservation Handbook: A Guide to basic Preservation. 40p. Disponível em: <http://www.illinoishistory.gov/Cemetery/INCLUDES/ILHistCemPres_9-09.pdf>. Acessado em: 1 de março de 2013.

Heinrichs K., Fitzner B. 2007. Stone monuments of the Nemrud Dag sanctuary / Turkey petrographical investigation and diagnosis of weathering damage.Z. dt. Ges. Geowiss.p.519-548. 
Henriques F.M.A., Delgado Rodrigues J., Aires-Barros L., Proença N. 2005. Materiais pétreos e similares - Terminologia das formas de alteração e degradação. LNEC, Lisboa, 39p.

ICOMOS. 2008. Illustrated Glossary on Stone Deterioration Patterns = Glossaire illustré sur les formes d'altération de la pierre. English-French ed. Monuments \& Sites 15. Paris:ICOMOS (International Council on Monuments and Sites) and ISCS (International Scientific Committee for Stone). Disponível em: http:/l international.icomos.org/publications/monuments_and_sites/15/pdf/Monuments_and_Si tes_15_ISCS_Glossary_Stone.pdf. Acesso:13/04/2012

Iñigo A.C., Vicente-Tavera S., Rives V., Vicente M.A. 1997. Color Changes in theSurface of Granitic Materials by Consolidated and/or Water Repellent Treatments.Color Research and Application, v. 22(2). p. 133-141.

IPT. 1990. Catálogo das rochas ornamentais do Estado de São Paulo. São Paulo. 122p.

Johnston S. F. 1996. The construction of colorimetry by committee.Science in context, v.9(4). p. 387-420.

King G. 2004. Michigan historic cemeteries preservation guide.203p. Disponível em: <http://www.michigan.gov/documents/hal_mhc_shpo_Cemetery_Guide_105082_7.pdf> . Acessado em: 1 de março de 2013.

Köhler W. 1988. Preservation Problems of Carrara-Marble Sculptures in PotsdamSanssouci.Proceedings. In.:VIth Intern. CongressonDeteriorationandConservationof Stone, Torún. p. 653-662.

Kuzmickas L., Del Lama E. A. 2009. Intemperismo nos monumentos pétreos do Cemitério da Consolação, São Paulo (SP). In: $11^{\circ}$ Simpósio de Geologia do Sudeste, 2009, São Pedro. Anais do $11^{\circ}$ Simpósio de Geologia do Sudeste, 2009. p. 129.

Kuzmickas L., Del Lama E. A. 2011. Roteiro geológico pelo Cemitério da Consolação - SP. In: $12^{\circ}$ Simpósio de Geologia do Sudeste, 2011, Nova Friburgo. Anais do $12^{\circ}$ Simpósio de Geologia do Sudeste. CD-ROM. 
Lopes L. da C., Frota M.N. 2009. Controle metrológico da cor aplicada à estamparia difital de materiais têxteis. Rio de Janeiro. 142p. Dissertação de Mestrado - Programa de PósGraduação em Metrologia, Qualidade e Inovação, Pontifícia Universidade Católica do Rio de Janeiro.

Luque A., Ruiz-Agudo E., Cultrone G., Sebastian E., Siegesmund S. 2011. Direct observation of microcrack development in marble causedby thermal weathering, Environ.Earth Sci., 62, p. 1375-1386.

Maccari Neto A. 2009. Análise de ocorrência de metamerismo em revestimentos cerâmicos. Dissertação de Mestrado - Universidade Federal do Rio Grande do Sul. 66p.

Machado P.P., Hotza D., Petter C.,Bergmann C.P. 1997.Controle de Qualidade para Revestimentos Cerâmicos através da Análise Colorimétrica de Superfície Vidrada Monocromática. Cerâmica Industrial. Vol. 2, p. 51-55.

Magma Stone. Disponível em: <http://www.magmastone.com.br>. Acessado em: 02 de fevereiro de 2012.

Maia, S. M. C. 2004. Estudo integrado geológico/tecnológico de rochas: Os granitos Flores e Jacarandá, RN. Dissertação de Mestrado. Centro de Ciências Exatas e da Terra, Universidade Federal do Rio Grande do Norte. 79p.

Marmoraria Tamoios. Disponível em: <http://www.marmorariatamoios.com.br>. Acessado em 02 de fevereiro de 2012.

Marques, E. A. G., Barroso, E. V., Menezes Filho, A. P., Vargas Jr., E. do A. 2010.Weathering zones on metamorphic rocks from Rio de Janeiro - Physical, mineralogical and geomechanical characterization. Engineering Geology.p.1-18.

Massachusetts Department of Conservation and Recreation. 2009. preservation guidelines for municipally owned historic burial grounds and cemeteries. 28p. Disponivel em: $<$ http://www.mass.gov/dcr/stewardship/histland/cemeteries_1-introduction.pdf>. Acessado em: 1 de março de 2013. 
Maxwell I. Nanda R. Urquhart D. 2001. Conservation of Historic Graveyards. Guide for Practitioners. Edinburgh: Historic Scotland. 180p.

Mello I.S de C., Chiodi Filho C. Chiodi D.K. 2011.Atlas de rochas ornamentais da Amazônia brasileira. CPRM. Projeto Consolidação e Sustentabilidade da Produção de Rochas para revestimento na construção civil da região Amazônica.301p.

Naik T. R., Malhorta V. M., Popovics J. S. 2004. The Ultrasonic Pulse VelocityMethod, In: Malhotra V. M., Carino N. J. (Eds.). 2004. Handbookonnondestructivetestingof concrete, CRC Press, Boca Raton; London. 2nd ed. p. 14.1-14.34.

National Trust of Austrália. 2008. Guidelines for Cemetery Conservation. 149p. Disponivel em:

<http://www.nationaltrust.org.au/Assets/9719/1/cemetery_conservation_guide.pdf>. Acessado em: 1 de março de 2013.

Nord A. G., Holenyi K. 1999. Sulpur deposition and damage on limestone and sandstone in Stockholm city buildings.Water, Air, and Soil Pollution. Vol. 109, p. 147-162.

Opus International Consultants Limited. 2005. Conservation Plan: Linwood Cemetery, New Zealand. 134p. Disponivel em: $<$ http://christchurchcitylibraries.com/heritage/cemeteries/linwood/DraftConservationPlan LinwoodCemetery.pdf>. Acessado em: 1 de março de 2013.

Papida S., Murphy W., May E. 2000. The use of sound velocity determination for the nondestructive estimation of physical and microbial weathering of limestones and dolomites. In: $9^{\text {th }}$ International Congress on Deterioration and Conservation of Stone, Veneza. 609$617 p$.

Pedras Ipiranga. Disponível em: <http://www.pedrasipiranga.com.br>. Acessado em: 02 de fevereiro de 2012.

Pellegrini S. B. 2004. Em cada canto de São Paulo um encanto de Brecheret. São Paulo: editora Nova América. 40p. 
Prieto B., Sanmartín P., Silva B., Martínez-Verdú F. 2010. Measuring the color of graniterocks: a propose procedure. Color Research and Application.Vol. 35, p. 368375.

Revista $A U$ - Arquitetura e Urbanismo. Disponível em: <http://www.revistaau.com.br/arquitetura-urbanismo/135/au-responde-227381.asp>. Acessado em: 1 de março de 2013.

Revista Forbes. 2009. Necroturismo: os cemitérios mais famosos do mundo, segundo a Forbes. Disponível em: http://vidaeestilo.terra.com.br/turismo/necroturismo-oscemiterios-mais-famosos-do-mundo-segundo-aforbes,f108392625237310VgnCLD100000bbcceb0aRCRD.html. Acesso: 04/6/2013.

Reys A. C. dos, Del Lama E. A., Dehira L. K. 2007.Monumentos da Cidade de São Paulo: formas de alteração e conservação. Revista CPC. São Paulo. n.5, p. 93-122.

Rigueira, R.J. de A. 2005. Avaliação da qualidade do café processado por via úmida, durante as operações e secagem e armazenagem. Tese de doutorado - Universidade Federal de Viçosa.

RILEM - Rèunion Internationale des Laboratoires et Experts des Matériaux NDT 1, 1972, Testing of concrete by the ultrasonic pulse method, Paris.

Rossi-Manaresi R., Tucci A. 1983. Ultrasonic test for the evaluation of the effectiveness of sandstoneconsolidation.In: 1a Conferenza Internazionale, Le Prove Non DistruttiveNellaConservazzioneDelle Opere D’arte. p. 11.1-11.17.

Santos M. C. R. dos. 2005. Uma contribuição ao estudo de deterioração de rochas. Dissertação (Mestrado) - Instituto de Pesquisa Tecnológica do Estado de São Paulo, São Paulo. 118p.

Santos, S.F. 2006. Síntese de Pigmentos Cerâmicos e Desenvolvimento de Cores em Porcelanas Feldspáticas. Dissertação de Mestrado - Universidade Federal do Rio de Janeiro. 57p. 
Santos S.F., Andrade M.C. de, Sampaio J.A., Luz A. B. da, Ogasawara T. 2006. Síntese de Pigmentos Cerâmicos de TiO2-xCeO2 pelo método dos precursores poliméricos. Anais do $50^{\circ}$ Congresso Brasileiro de Cerâmica, Blumenau-SC, CD-ROM.

Silva, L. C. T. da. 2005. Avaliação da Degradação de Rochas em Fachadas de PrédiosHistóricos: Os Exemplos do Teatro Municipal e do Paço Imperial, Cidade do Rio de Janeiro. Dissertação de Mestrado. Instituto de Geociências. Universidade Federaldo Rio de Janeiro. 109p.

Schabbach L.M. 2004. Utilização da espectrofotometria na caracterização e predição de cores de esmaltes cerâmicos monocromáticos opacos. Tese de doutorado, Florianópolis: Universidade Federal de Santa Catarina. 192p.

Serviço Funerário de São Paulo. 2010a. História e arte no cemitério da Consolação. 16p. Disponível em: <http://www.prefeitura.sp.gov.br/cidade/upload/cemiterio_baixa_1219246534.pdf>. Acessado em: 1 de março de 2013.

Serviço Funerário de São Paulo. 2010b. Cemitério da Consolação: guia de visitação. 2p. Disponível em: <http://www.prefeitura.sp.gov.br/cidade/upload/cemiterio\%20mapa\%20baixa_1219246 518.pdf>. Acessado em: 1 de março de 2013.

Siegesmund S., Weiss T.,Vollbrecht A. 2002. NaturalStone, Weathering Phenomena, ConservationStrategies and Case Studies.Geological Society,London, Special Publications, 205p.

Silva R.A., Petter C.O., Schneider I.A.H. 2007. Avaliação da perda da coloração artificial de ágatas. Revista Escola de Minas. Vol.60, p.477-482.

Souza F. de, Teles R.F., Ribeiro P.G., Camargos A. M., Menezzi C.H.S.D. 2010. Resistência natural e alteração da cor da madeira de Machaerium scleroxylon Tul. submetida ao ataque de fungos apodrecedores. Scientia Forestalis. Vol.38, n.87, p. 449-457.

Souza J.C., Rolim Filho J.L.,Barros M.L.S.C., Lira B.B. Silva S.A., Rieck F.E.2008.Análise colorimétrica de rochas ornamentais. Estudos Geológicos. Vol. 18, p. 55-64. 
Texas Historical Commission. 2011. Preserving Historic Cemeteries: Texas Preservation Guidelines. $16 p$ Disponível em: $<$ http://www.thc.state.tx.us/public/upload/forms/preserving-historic-cemeteries2011.pdf>. Acessado em: 1 de março de 2013.

TFB - Túmulos Famosos do Brasil, Arte Tumular. Disponível em: <http://tumuloartistabrasileiro.blogspot.com>. Acessado em: 20 de agosto de 2010.

Timpanaro M. 2006. A morte como memória: Imigrantes nos cemitérios da Consolação e do Brás. Dissertação (Pós-Graduação) - Faculdade de Filosofia, Letras e Ciências Humanas, Universidade de São Paulo, São Paulo. 246p.

Topal T., Doyuran V. 1995. UltrassonictestofartificiallyweatheredCappadociantuff. In: Preservation and restoration of cultural heritage, École Polytechnique. p. 205-211.

Valladares C. do P. 1972. Um estudo da arte cemiterial ocorrido no Brasil desde as sepulturas de Igrejas e as catacumbas de ordens e confrarias até as necrópoles secularizadas - Realizado no período de 1960 a 1970. Rio de Janeiro: Conselho Federal de Cultura, 02 volumes.

X-Rite. 2007. A guide to undertstanding color comunication. 24p.

Ziegler, G. L. F., Carmo, P. I. O do. 2003. Inspeção e manutenção de estruturas deconcreto armado: uso de ensaios não destrutivos. RS. In: XVIII CongressoRegional de Iniciação Científica e Tecnologia. 5p. 
ANEXOS 


\section{ANEXO 1}

Túmulo da Família Pereira Pinto (1868-1886)

\begin{tabular}{|c|c|c|c|}
\hline \multicolumn{4}{|c|}{$\begin{array}{c}\text { Primeiro Nível - Bloco da Frente } \\
\text { Transdutor 54 kHz I Método Direto }\end{array}$} \\
\hline & $\mathbf{t}(\mathbf{m s})$ & $\mathbf{d}(\mathbf{c m})$ & $\mathbf{V ~ ( m / s )}$ \\
\hline $\mathbf{1}$ & 326,6 & 80,6 & 2467,9 \\
\hline $\mathbf{3}$ & 319,2 & 80,6 & 2525,1 \\
\hline Média & 326,4 & 80,6 & 2469,4 \\
\hline Desvio Padrão & & & 2487,4 \\
\hline Coef. De Var. & & & 32,6 \\
\hline
\end{tabular}

\begin{tabular}{|c|c|c|c|}
\hline \multicolumn{4}{|c|}{$\begin{array}{c}\text { Primeiro Nível - Bloco de Trás } \\
\text { Transdutor 54 kHz I Método Direto }\end{array}$} \\
\hline & $\mathbf{t}(\mathbf{m s})$ & $\mathbf{d}(\mathbf{c m})$ & $\mathbf{V}(\mathbf{m} / \mathbf{s})$ \\
\hline $\mathbf{4}$ & 211,2 & 80,6 & 3816,3 \\
\hline $\mathbf{5}$ & 188,1 & 80,6 & 4285,0 \\
\hline $\mathbf{6}$ & 212,5 & 80,6 & 3792,9 \\
\hline Média & & & 3964,7 \\
\hline Desvio Padrão & & & 277,6 \\
\hline Coef. De Var. & & & 7,0 \\
\hline
\end{tabular}

\begin{tabular}{|c|c|c|c|}
\hline \multicolumn{4}{|c|}{$\begin{array}{c}\text { Primeiro Nível - Bloco da Frente } \\
\text { Transdutor 54 kHz I Método Semidireto }\end{array}$} \\
\hline & $\mathbf{t}(\mathbf{m s})$ & $\mathbf{d}(\mathbf{c m})$ & $\mathbf{V}(\mathbf{m} / \mathbf{s})$ \\
\hline $\mathbf{1 / 1}$ (Lado Esquerdo) & 46,3 & 13,2 & 2851,0 \\
\hline $\mathbf{2 / 2}$ (Lado Esquerdo) & 144,7 & 28,3 & 1955,8 \\
\hline 3/3 (Lado Esquerdo) & 295,5 & 42,5 & 1438,2 \\
\hline $\mathbf{1 / 1}$ (Lado Direito) & 48,2 & 14,7 & 3049,8 \\
\hline 2/2 (Lado Direito) & 171,9 & 29,0 & 1687,0 \\
\hline 3/3 (Lado Direito) & 217,2 & 43,6 & 2007,4 \\
\hline Média & & & 2164,9 \\
\hline Desvio Padrão & & & $\mathbf{6 4 4 , 8}$ \\
\hline Coef. De Var. & & & $\mathbf{2 9 , 8}$ \\
\hline
\end{tabular}

\begin{tabular}{|c|c|c|c|}
\hline \multicolumn{4}{|c|}{$\begin{array}{c}\text { Primeiro Nível - Bloco de Trás } \\
\text { Transdutor } 54 \mathrm{kHz} \text { | Método Semidireto }\end{array}$} \\
\hline & $t(\mathrm{~ms})$ & $\mathrm{d}(\mathrm{cm})$ & $\mathrm{V}(\mathrm{m} / \mathrm{s})$ \\
\hline 4/4 (Lado Esquerdo) & 43,2 & 13,0 & 3009,3 \\
\hline 5/5 (Lado Esquerdo) & 77,5 & 28,0 & 3612,9 \\
\hline 6/6 (Lado Esquerdo) & 129,2 & 42,9 & 3320,4 \\
\hline 4/4 (Lado Direito) & 13,9 & 3217,6 & 13,9 \\
\hline 5/5 (Lado Direito) & 27,5 & 3594,8 & 27,5 \\
\hline 6/6 (Lado Direito) & 43,3 & 2125,7 & 43,3 \\
\hline Média & & & 3146,8 \\
\hline Desvio Padrão & & & 550,4 \\
\hline Coef. De Var. & & & 17,5 \\
\hline
\end{tabular}




\begin{tabular}{|c|c|c|c|}
\hline \multicolumn{4}{|c|}{$\begin{array}{l}\text { Quarto Nível - Horizontal com a Vertical } \\
\text { Transdutor 54 kHz I Método Semidireto }\end{array}$} \\
\hline & $\mathbf{t}(\mathbf{m s})$ & $\mathbf{d} \mathbf{( c m})$ & $\mathbf{V ~ ( m / s )}$ \\
\hline $\mathbf{1 / 1}$ & 71,9 & 14,9 & 2072,3 \\
\hline $\mathbf{2 / 2}$ & 57,3 & 14,9 & 2600,3 \\
\hline $\mathbf{3 / 3}$ & 54,0 & 14,0 & 2592,6 \\
\hline $\mathbf{4 / 4}$ & 52,1 & 14,0 & 2687,1 \\
\hline $\mathbf{5 / 5}$ & 92,1 & 14,0 & 1520,1 \\
\hline $\mathbf{6 / 6}$ & 46,0 & 13,3 & 2891,3 \\
\hline $\mathbf{7 / 7}$ & 70,3 & 13,3 & 1891,9 \\
\hline Média & & & $\mathbf{2 3 2 2 , 2}$ \\
\hline Desvio Padrão & & & $\mathbf{4 9 9 , 8}$ \\
\hline Coef. De Var. & & & $\mathbf{2 1 , 5}$ \\
\hline
\end{tabular}

\begin{tabular}{|c|c|c|c|}
\hline \multicolumn{4}{|c|}{$\begin{array}{c}\text { Quarto Nível - Horizontal } \\
\text { Transdutor 54 kHz I Método Indireto }\end{array}$} \\
\hline & $\mathbf{t}(\mathbf{m s})$ & $\mathbf{d} \mathbf{( c m})$ & $\mathbf{V ~ ( m / s )}$ \\
\hline $\mathbf{1 / 2}$ & 89,2 & 10,0 & 1121,1 \\
\hline $\mathbf{1 / 3}$ & 161,2 & 20,0 & 1240,7 \\
\hline $\mathbf{1 / 4}$ & 226,8 & 30,0 & 1322,8 \\
\hline $\mathbf{1 / 2}$ & 91,4 & 10,0 & 1094,1 \\
\hline $\mathbf{2 / 3}$ & 85,7 & 10,0 & 1166,9 \\
\hline $\mathbf{3 / 4}$ & 69,7 & 10,0 & 1434,7 \\
\hline $\mathbf{4 / 5}$ & 73,4 & 10,0 & 1362,4 \\
\hline $\mathbf{5 / 6}$ & 76,5 & 10,0 & 1307,2 \\
\hline $\mathbf{6 / 7}$ & 71,0 & 10,0 & 1408,5 \\
\hline Média & & & 1273,1 \\
\hline Desvio Padrão & & & $\mathbf{1 2 4 , 3}$ \\
\hline Coef. De Var. & & & 9,8 \\
\hline
\end{tabular}

\begin{tabular}{|c|c|c|c|}
\hline \multicolumn{4}{|c|}{$\begin{array}{c}\text { Quarto Nível - Vertical } \\
\text { Transdutor } 54 \text { kHz I Método Indireto }\end{array}$} \\
\hline & $\mathrm{t}(\mathrm{ms})$ & $\mathrm{d}(\mathrm{cm})$ & $\mathrm{V}(\mathrm{m} / \mathrm{s})$ \\
\hline $1 / 2$ & 80,6 & 10,0 & 1240,7 \\
\hline $1 / 3$ & 152,4 & 20,0 & 1312,3 \\
\hline $1 / 4$ & 261,3 & 30,0 & 1148,1 \\
\hline $1 / 2$ & 86,2 & 10,0 & 1160,1 \\
\hline $2 / 3$ & 88,0 & 10,0 & 1136,4 \\
\hline $3 / 4$ & 86,0 & 10,0 & 1162,8 \\
\hline $4 / 5$ & 103,0 & 10,0 & 970,9 \\
\hline $5 / 6$ & 67,4 & 10,0 & 1483,7 \\
\hline $6 / 7$ & 67,4 & 10,0 & 1483,7 \\
\hline Média & & & 1233,2 \\
\hline Desvio Padrão & & & 168,6 \\
\hline Coef. De Var. & & & 13,7 \\
\hline
\end{tabular}


Estátua Cristo (1962) - Escultor Elio de Giusto

\begin{tabular}{|c|c|c|c|}
\hline \multicolumn{4}{|c|}{ Estátua } \\
\hline & $\mathbf{t} \mathbf{( m s )}$ & $\mathbf{d}(\mathbf{c m})$ & $\mathbf{V ~ ( m / s )}$ \\
\hline $\mathbf{1}$ & 95,0 & 27,0 & 2842,1 \\
\hline $\mathbf{2}$ & 131,7 & 30,0 & 2277,9 \\
\hline $\mathbf{3}$ & 83,0 & 38,5 & 4638,6 \\
\hline $\mathbf{4}$ & 92,0 & 31,0 & 3369,6 \\
\hline $\mathbf{5}$ & 96,3 & 28,0 & 2907,6 \\
\hline Média & & & 3207,1 \\
\hline Desvio Padrão & & & $\mathbf{8 8 9 , 1}$ \\
\hline Coef. De Var. & & & $\mathbf{2 7 , 7}$ \\
\hline
\end{tabular}

\begin{tabular}{|c|c|c|c|}
\hline \multicolumn{4}{|c|}{ Estátua } \\
\hline & $\mathbf{t}(\mathbf{m s})$ & $\mathbf{d}(\mathbf{c m})$ & $\mathbf{V}(\mathbf{m} / \mathbf{s})$ \\
\hline $\mathbf{1}$ & 95,0 & 27,0 & 2842,1 \\
\hline $\mathbf{2}$ & 131,7 & 30,0 & 2277,9 \\
\hline $\mathbf{3}$ & 83,0 & 38,5 & 4638,6 \\
\hline $\mathbf{4}$ & 92,0 & 31,0 & 3369,6 \\
\hline $\mathbf{5}$ & 96,3 & 28,0 & 2907,6 \\
\hline Média & & & 3207,1 \\
\hline Desvio Padrão & & & $\mathbf{8 8 9 , 1}$ \\
\hline Coef. De Var. & & & $\mathbf{2 7 , 7}$ \\
\hline
\end{tabular}

Estátua O Sepultamento (1923) - Escultor Victor Brecheret

Estátua (Análise: 03/04/2012)

Transdutor 150 kHz I Método Direto

\begin{tabular}{|c|c|c|c|}
\hline & $\mathbf{t}(\mathbf{m s})$ & $\mathbf{d} \mathbf{( c m})$ & $\mathbf{V}(\mathbf{m} / \mathbf{s})$ \\
\hline $\mathbf{1}$ & 40,1 & 18,2 & 4538,7 \\
\hline $\mathbf{2}$ & 45,2 & 19,0 & 4203,5 \\
\hline $\mathbf{3}$ & 53,1 & 22,0 & 4143,1 \\
\hline $\mathbf{4}$ & 30,2 & 18,0 & 5960,3 \\
\hline $\mathbf{5}$ & 32,5 & 21,0 & 6461,5 \\
\hline $\mathbf{6}$ & 35,9 & 22,0 & 6128,1 \\
\hline $\mathbf{7}$ & 47,9 & 19,5 & 4071,0 \\
\hline $\mathbf{8}$ & 76,5 & 11,0 & 1437,9 \\
\hline $\mathbf{9}$ & 60,3 & 13,0 & 2155,9 \\
\hline Média & & & 4344,4 \\
\hline Desvio Padrão & & & $\mathbf{1 7 2 0 , 7}$ \\
\hline Coef. De Var. & & & 39,6 \\
\hline
\end{tabular}




\begin{tabular}{|c|c|c|c|}
\hline \multicolumn{4}{|c|}{$\begin{array}{c}\text { Estátua (Análise: 03/04/2012) } \\
\text { Transdutor } 54 \text { kHz I Método Direto }\end{array}$} \\
\hline & $\mathrm{t}(\mathrm{ms})$ & $\mathrm{d}(\mathrm{cm})$ & $\mathrm{V}(\mathrm{m} / \mathrm{s})$ \\
\hline 1 & 39 & 18,2 & 4666,7 \\
\hline 2 & 44,3 & 19,0 & 4288,9 \\
\hline 3 & 51,9 & 22,0 & 4238,9 \\
\hline 4 & 29,1 & 18,0 & 6185,6 \\
\hline 5 & 30,9 & 21,0 & 6796,1 \\
\hline 6 & 34,6 & 22,0 & 6358,4 \\
\hline 7 & 47,5 & 19,5 & 4105,3 \\
\hline 8 & 42,4 & 11,0 & 2594,3 \\
\hline 9 & 34,2 & 13,0 & 3801,2 \\
\hline 10 & 92,5 & 37,0 & 4000,0 \\
\hline 11 & 133 & 37,0 & 2782,0 \\
\hline 12 & 97,2 & 37,0 & 3806,6 \\
\hline 13 & 97,2 & 37,0 & 3806,6 \\
\hline 14 & 95,2 & 37,0 & 3886,6 \\
\hline Média & & & 4379,8 \\
\hline Desvio Padrão & & & 1250,2 \\
\hline Coef. De Var. & & & 28,5 \\
\hline
\end{tabular}

\begin{tabular}{|c|c|c|c|}
\hline \multicolumn{4}{|c|}{$\begin{array}{l}\text { Estátua (Análise: 01/08/2012) } \\
\text { Transdutor } 150 \mathrm{kHz} \text { I Método Direto }\end{array}$} \\
\hline & $t(\mathrm{~ms})$ & d (cm) & $V(\mathrm{~m} / \mathrm{s})$ \\
\hline 1 & 34,4 & 13,9 & 4040,7 \\
\hline 2 & 38,3 & 15,6 & 4073,1 \\
\hline 3 & 57,2 & 16,2 & 2832,2 \\
\hline 4 & 43,3 & 17,1 & 3949,2 \\
\hline 5 & 64 & 18,2 & 2843,8 \\
\hline 6 & 74,8 & 21,2 & 2834,2 \\
\hline 7 & 36,3 & 15,0 & 4132,2 \\
\hline 8 & 46,6 & 16,4 & 3519,3 \\
\hline 9 & 52,3 & 18,2 & 3479,9 \\
\hline 15 & 28,4 & 11,0 & 3873,2 \\
\hline 16 & 45 & 10,0 & 2222,2 \\
\hline 17 & 55,2 & 10,0 & 1811,6 \\
\hline 18 & 66,8 & 13,5 & 2021,0 \\
\hline 19 & 66,5 & 13,5 & 2030,1 \\
\hline Média & & & 3118,8 \\
\hline Desvio Padrão & & & 853,9 \\
\hline Coef. De Var. & & & 27,4 \\
\hline
\end{tabular}




\begin{tabular}{|c|c|c|c|}
\hline \multicolumn{4}{|c|}{$\begin{array}{c}\text { Estátua (Análise: 01/08/2012) } \\
\text { Transdutor } 54 \text { kHz I Método Direto }\end{array}$} \\
\hline & $t(m s)$ & d (cm) & V (m/s) \\
\hline 1 & 32,2 & 13,9 & 4316,8 \\
\hline 2 & 36,5 & 15,6 & 4274,0 \\
\hline 3 & 38,2 & 16,2 & 4240,8 \\
\hline 4 & 40,7 & 17,1 & 4201,5 \\
\hline 5 & 44,5 & 18,2 & 4089,9 \\
\hline 6 & 48,2 & 21,2 & 4398,3 \\
\hline 7 & 26,1 & 15,0 & 5747,1 \\
\hline 8 & 28,3 & 16,4 & 5795,1 \\
\hline 9 & 33,1 & 18,2 & 5498,5 \\
\hline 10 & 88,6 & 36,9 & 4164,8 \\
\hline 11 & 92,3 & 36,9 & 3997,8 \\
\hline 12 & 97,6 & 36,9 & 3780,7 \\
\hline 13 & 97,5 & 36,9 & 3784,6 \\
\hline 14 & 93,3 & 36,9 & 3955,0 \\
\hline 15 & 27,7 & 11,0 & 3971,1 \\
\hline 16 & 26,2 & 10,0 & 3816,8 \\
\hline 17 & 27,9 & 10,0 & 3584,2 \\
\hline 18 & 32,8 & 13,5 & 4115,9 \\
\hline 19 & 31,8 & 13,5 & 4245,3 \\
\hline Média & & & 4314,6 \\
\hline Desvio Padrão & & & 644,8 \\
\hline Coef. De Var. & & & 14,9 \\
\hline
\end{tabular}

Estátua Interrogação (1923) - Escultor Francisco Leopoldo e Silva

\begin{tabular}{|c|c|c|c|}
\hline \multicolumn{4}{|c|}{ Estátua Interrogação } \\
Transdutor 54 kHz I Método Direto \\
\hline $\mathbf{1}$ & $\mathbf{t}(\mathbf{m s})$ & $\mathbf{d} \mathbf{( c m})$ & $\mathbf{V} \mathbf{( m / s )}$ \\
\hline $\mathbf{2}$ & 53,8 & 25,0 & 4646,8 \\
\hline $\mathbf{3}$ & 71,0 & 35,0 & 4929,6 \\
\hline $\mathbf{4}$ & 39,8 & 16,7 & 4196,0 \\
\hline $\mathbf{5}$ & 44,0 & 17,7 & 4022,7 \\
\hline $\mathbf{6}$ & 55,6 & 21,4 & 3848,9 \\
\hline Média & 37,2 & 15,1 & 4059,1 \\
\hline Desvio Padrão & & & $\mathbf{4 0 3 1 , 7}$ \\
\hline Coef. De Var. & & & $\mathbf{1 2 3 , 7}$ \\
\hline
\end{tabular}




\begin{tabular}{|c|c|c|c|}
\hline \multicolumn{4}{|c|}{ Estátua Interrogação } \\
Transdutor 150 kHz I Método Direto \\
\hline $\mathbf{1}$ & $\mathbf{t}(\mathbf{m s})$ & $\mathbf{d} \mathbf{( c m})$ & $\mathbf{V} \mathbf{( m / s )}$ \\
\hline $\mathbf{2}$ & 80,0 & 25,0 & 3125,0 \\
\hline $\mathbf{3}$ & 104,4 & 35,0 & 3352,5 \\
\hline $\mathbf{4}$ & 37,8 & 16,7 & 4418,0 \\
\hline $\mathbf{5}$ & 40,9 & 17,7 & 4327,6 \\
\hline $\mathbf{6}$ & 68,0 & 21,4 & 3147,1 \\
\hline Média & 35,2 & 15,1 & 4289,8 \\
\hline Desvio Padrão & & & $\mathbf{4 0 4 5 , 6}$ \\
\hline Coef. De Var. & & & $\mathbf{5 2 0 , 9}$ \\
\hline
\end{tabular}

\begin{tabular}{|c|c|c|c|}
\hline \multicolumn{4}{|c|}{ Pilar NW } \\
\hline & $\mathbf{t}(\mathbf{m s})$ & $\mathbf{d}(\mathbf{c m})$ & $\mathbf{V}(\mathbf{m} / \mathbf{s})$ \\
\hline $\mathbf{1}$ & 67,0 & 25,0 & 3731,3 \\
\hline $\mathbf{2}$ & 94,1 & 35,0 & 3719,4 \\
\hline Média & & & 3725,4 \\
\hline Desvio Padrão & & & $\mathbf{8 , 4}$ \\
\hline Coef. De Var. & & & $\mathbf{0 , 2}$ \\
\hline
\end{tabular}

\begin{tabular}{|c|c|c|c|}
\hline \multicolumn{4}{|c|}{ Pilar NW } \\
\hline & $\mathbf{t}(\mathbf{m s})$ & $\mathbf{d}(\mathbf{c m})$ & $\mathbf{V}(\mathbf{m} / \mathbf{s})$ \\
\hline $\mathbf{1}$ & 59,7 & 25,0 & 4187,6 \\
\hline $\mathbf{2}$ & 87,3 & 35,0 & 4009,2 \\
\hline Média & & & 4098,4 \\
\hline Desvio Padrão & & & 126,2 \\
\hline Coef. De Var. & & & 3,1 \\
\hline
\end{tabular}

\begin{tabular}{|c|c|c|c|}
\hline \multicolumn{4}{|c|}{ Pilar NW } \\
Transdutor 54 kHz I Método Semidireto \\
\hline & $\mathbf{t}(\mathbf{m s})$ & $\mathbf{d}(\mathbf{c m})$ & $\mathbf{V}(\mathbf{m} / \mathbf{s})$ \\
\hline $\mathbf{1 / 3}$ & 32,9 & 14,0 & 4255,3 \\
\hline $\mathbf{1 / 2}$ & 32,9 & 14,9 & 4528,9 \\
\hline $\mathbf{1 / 5}$ & 57,3 & 30,0 & 5235,6 \\
\hline $\mathbf{1 / 4}$ & 72,1 & 30,0 & 4160,9 \\
\hline Média & & & $\mathbf{4 5 4 5 , 2}$ \\
\hline Desvio Padrão & & & $\mathbf{4 8 6 , 0}$ \\
\hline Coef. De Var. & & & $\mathbf{1 0 , 7}$ \\
\hline
\end{tabular}

\begin{tabular}{|c|c|c|c|}
\hline \multicolumn{4}{|c|}{ Pilar NE } \\
\hline & $\mathbf{t}(\mathbf{m s})$ & $\mathbf{d}(\mathbf{c m})$ & $\mathbf{V}(\mathbf{m} / \mathbf{s})$ \\
\hline $\mathbf{1}$ & 56,0 & 25,0 & 4464,3 \\
\hline $\mathbf{2}$ & 74,9 & 35,0 & 4672,9 \\
\hline Média & & Média & 4568,6 \\
\hline Desvio Padrão & & D.P. & 147,5 \\
\hline Coef. De Var. & & Coef. & 3,2 \\
\hline
\end{tabular}




\begin{tabular}{|c|c|c|c|}
\hline \multicolumn{4}{|c|}{ Pilar NE } \\
\hline & Transdutor 54 kHz I Método Semidireto \\
\hline $\mathbf{1 / 3}$ & $\mathbf{t}(\mathbf{m s})$ & $\mathbf{d}(\mathbf{c m})$ & $\mathbf{V}(\mathbf{m} / \mathbf{s})$ \\
\hline $\mathbf{1 / 2}$ & 34,2 & 15,6 & 4561,4 \\
\hline $\mathbf{1 / 5}$ & 36,1 & 15,6 & 4321,3 \\
\hline $\mathbf{1 / 4}$ & 69,3 & 33,1 & 4776,3 \\
\hline Média & 68,4 & 32,6 & 4766,1 \\
\hline Desvio Padrão & & & 4606,3 \\
\hline Coef. De Var. & & & $\mathbf{2 1 4 , 2}$ \\
\hline
\end{tabular}

\begin{tabular}{|c|c|c|c|}
\hline \multicolumn{4}{|c|}{ Pilar NE } \\
\hline & $\mathbf{t}(\mathbf{m s})$ & $\mathbf{d}(\mathbf{c m})$ & $\mathbf{V}(\mathbf{m} / \mathbf{s})$ \\
\hline $\mathbf{1}$ & 80,9 & 25,0 & 3090,2 \\
\hline $\mathbf{2}$ & 139,4 & 35,0 & 2510,8 \\
\hline Média & & & $\mathbf{2 8 0 0 , 5}$ \\
\hline Desvio Padrão & & & 409,8 \\
\hline Coef. De Var. & & & 14,6 \\
\hline
\end{tabular}

\begin{tabular}{|c|c|c|c|}
\hline \multicolumn{4}{|c|}{$\begin{array}{c}\text { Pilar SW } \\
\text { Transdutor } 54 \text { kHz | Método Direto }\end{array}$} \\
\hline & $t(\mathrm{~ms})$ & $\mathrm{d}(\mathrm{cm})$ & $\mathrm{V}(\mathrm{m} / \mathrm{s})$ \\
\hline 1 & 53,8 & 25,0 & 4646,8 \\
\hline 2 & 74,3 & 35,0 & 4710,6 \\
\hline Média & & & 4678,7 \\
\hline Desvio Padrão & & & 45,1 \\
\hline Coef. De Var. & & & 1,0 \\
\hline
\end{tabular}

\begin{tabular}{|c|c|c|c|}
\hline \multicolumn{4}{|c|}{ Pilar SW } \\
\hline & $\mathbf{t}(\mathbf{m s})$ & $\mathbf{d}(\mathbf{c m})$ & $\mathbf{V} \mathbf{( m / s})$ \\
\hline $\mathbf{1}$ & 70,8 & 25,0 & 3531,1 \\
\hline $\mathbf{2}$ & 93,4 & 35,0 & 3747,3 \\
\hline Média & & & 3639,2 \\
\hline Desvio Padrão & & & 152,9 \\
\hline Coef. De Var. & & & 4,2 \\
\hline
\end{tabular}

\begin{tabular}{|c|c|c|c|}
\hline \multicolumn{4}{|c|}{ Pilar SW } \\
Transdutor 54 kHz I Método Semidireto \\
\hline $\mathbf{1 / 3}$ & $\mathbf{t}(\mathbf{m s})$ & $\mathbf{d}(\mathbf{c m})$ & $\mathbf{V}(\mathbf{m} / \mathbf{s})$ \\
\hline $\mathbf{1 / 2}$ & 30,7 & 14,5 & 4723,1 \\
\hline $\mathbf{1 / 5}$ & 29,2 & 14,5 & 4965,8 \\
\hline $\mathbf{1 / 4}$ & 63,9 & 28,5 & 4460,1 \\
\hline Média & 63,4 & 30,0 & 4731,9 \\
\hline Desvio Padrão & & & $\mathbf{4 7 2 0 , 2}$ \\
\hline Coef. De Var. & & & $\mathbf{2 0 6 , 6}$ \\
\hline
\end{tabular}




\begin{tabular}{|c|c|c|c|}
\hline \multicolumn{4}{|c|}{ Pilar SE } \\
\hline & $\mathbf{t}(\mathbf{m s})$ & $\mathbf{d}(\mathbf{c m})$ & $\mathbf{V} \mathbf{( m / s})$ \\
\hline $\mathbf{1}$ & 58,0 & 25,0 & 4310,3 \\
\hline $\mathbf{2}$ & 80,8 & 35,0 & 4331,7 \\
\hline Média & & & 4321,0 \\
\hline Desvio Padrão & & & 15,1 \\
\hline Coef. De Var. & & & 0,3 \\
\hline
\end{tabular}

\begin{tabular}{|c|c|c|c|}
\hline \multicolumn{4}{|c|}{$\begin{array}{c}\text { Pilar SE } \\
\text { Transdutor } 150 \mathrm{kHz} \text { | Método Direto }\end{array}$} \\
\hline & $t(m s)$ & $d(\mathrm{~cm})$ & $\mathrm{V}(\mathrm{m} / \mathrm{s})$ \\
\hline 1 & 62,6 & 25,0 & 3993,6 \\
\hline 2 & 86,0 & 35,0 & 4069,8 \\
\hline Média & & & 4031,7 \\
\hline Desvio Padrão & & & 53,9 \\
\hline Coef. De Var. & & & 1,3 \\
\hline
\end{tabular}

\begin{tabular}{|c|c|c|c|}
\hline \multicolumn{4}{|c|}{ Pilar SE } \\
\hline & $\mathbf{t}(\mathbf{m s})$ & $\mathbf{d}(\mathbf{c m})$ & $\mathbf{V} \mathbf{( m / s})$ \\
\hline $\mathbf{1 / 3}$ & 33,3 & 15,1 & 4534,5 \\
\hline $\mathbf{1 / 2}$ & 35,0 & 15,1 & 4314,3 \\
\hline $\mathbf{1 / 5}$ & 74,7 & 30,4 & 4069,6 \\
\hline $\mathbf{1 / 4}$ & 73,8 & 30,4 & 4119,2 \\
\hline Média & & & $\mathbf{4 2 5 9 , 4}$ \\
\hline Desvio Padrão & & & $\mathbf{2 1 1 , 6}$ \\
\hline Coef. De Var. & & & 5,0 \\
\hline
\end{tabular}

\begin{tabular}{|c|c|c|c|}
\hline \multicolumn{4}{|c|}{ Lápide } \\
\hline & $\mathbf{t}$ (ms) & $\mathbf{d}(\mathbf{c m})$ & $\mathbf{V}(\mathbf{m} / \mathbf{s})$ \\
\hline $\mathbf{1}$ & 23,0 & 11,2 & 4860,9 \\
\hline $\mathbf{2}$ & 23,5 & 11,2 & 4757,4 \\
\hline $\mathbf{3}$ & 24,9 & 11,2 & 4490,0 \\
\hline $\mathbf{4}$ & 23,6 & 11,2 & 4737,3 \\
\hline $\mathbf{5}$ & 21,9 & 11,2 & 5105,0 \\
\hline $\mathbf{6}$ & 21,0 & 11,2 & 5323,8 \\
\hline $\mathbf{7}$ & 21,1 & 11,2 & 5298,6 \\
\hline $\mathbf{8}$ & 21,2 & 11,2 & 5273,6 \\
\hline $\mathbf{9}$ & 21,0 & 11,2 & 5323,8 \\
\hline Média & & & 5018,9 \\
\hline Desvio Padrão & & & 314,0 \\
\hline Coef. De Var. & & & 6,3 \\
\hline
\end{tabular}




\begin{tabular}{|c|c|c|c|}
\hline \multicolumn{4}{|c|}{ Lápide Horizontal } \\
\hline & $\mathbf{t}(\mathbf{m s})$ & $\mathbf{d}(\mathbf{c m})$ & $\mathbf{V}(\mathbf{m} / \mathbf{s})$ \\
\hline $\mathbf{1 / 2}$ & 59,6 & 10,0 & 1677,9 \\
\hline $\mathbf{1 / 3}$ & 71,9 & 20,0 & 2781,6 \\
\hline $\mathbf{1 / 4}$ & 116,2 & 30,0 & 2581,8 \\
\hline $\mathbf{1 / 5}$ & 170,0 & 40,0 & 2352,9 \\
\hline $\mathbf{1 / 6}$ & 233,0 & 50,0 & 2145,9 \\
\hline $\mathbf{1 / 7}$ & 282,1 & 60,0 & 2126,9 \\
\hline $\mathbf{1 / 8}$ & 345,9 & 70,0 & 2023,7 \\
\hline $\mathbf{1 / 9}$ & 400,1 & 80,0 & 1999,5 \\
\hline $\mathbf{1 / 2}$ & 59,6 & 10,0 & 1677,9 \\
\hline $\mathbf{2 / 3}$ & 25,8 & 10,0 & 3876,0 \\
\hline $\mathbf{3 / 4}$ & 19,9 & 10,0 & 5025,1 \\
\hline $\mathbf{4 / 5}$ & 19,9 & 10,0 & 5025,1 \\
\hline $\mathbf{5 / 6}$ & 21,4 & 10,0 & 4672,9 \\
\hline $\mathbf{6 / 7}$ & 26,4 & 10,0 & 3787,9 \\
\hline $\mathbf{7 / 8}$ & 22,3 & 10,0 & 4484,3 \\
\hline Média & & & 3198,4 \\
\hline Desvio Padrão & & & $\mathbf{1 1 7 8 , 2}$ \\
\hline Coef. De Var. & & & 36,8 \\
\hline
\end{tabular}

\begin{tabular}{|c|c|c|c|}
\hline \multicolumn{4}{|c|}{ Lápide Vertical } \\
\hline & $\mathbf{t}(\mathbf{m s})$ & $\mathbf{d} \mathbf{( c m})$ & $\mathbf{V} \mathbf{( m / s )}$ \\
\hline $\mathbf{1 / 2}$ & 77,4 & 10,0 & 1292,0 \\
\hline $\mathbf{1 / 3}$ & 130,6 & 20,0 & 1531,4 \\
\hline $\mathbf{1 / 4}$ & 107,3 & 30,0 & 2795,9 \\
\hline $\mathbf{1 / 5}$ & 162,0 & 40,0 & 2469,1 \\
\hline $\mathbf{1 / 6}$ & 210,1 & 50,0 & 2379,8 \\
\hline $\mathbf{1 / 7}$ & 249,1 & 60,0 & 2408,7 \\
\hline $\mathbf{1 / 8}$ & 371,7 & 70,0 & 1883,2 \\
\hline $\mathbf{1 / 9}$ & 416,9 & 80,0 & 1918,9 \\
\hline $\mathbf{1 / 2}$ & 23,2 & 10,0 & 4310,3 \\
\hline $\mathbf{2 / 3}$ & 22,2 & 10,0 & 4504,5 \\
\hline $\mathbf{3 / 4}$ & 24,6 & 10,0 & 4065,0 \\
\hline $\mathbf{4 / 5}$ & 24,0 & 10,0 & 4166,7 \\
\hline $\mathbf{5 / 6}$ & 55,8 & 10,0 & 1792,1 \\
\hline $\mathbf{6 / 7}$ & 24,4 & 10,0 & 4098,4 \\
\hline $\mathbf{7 / 8}$ & 31,0 & 10,0 & 3225,8 \\
\hline Média & & & 2901,6 \\
\hline Desvio Padrão & & & 1093,2 \\
\hline Coef. De Var. & & & 37,7 \\
\hline
\end{tabular}


Estátua Prece (1945) - Escultor Bruno Giorgi

\begin{tabular}{|c|c|c|c|}
\hline \multicolumn{4}{|c|}{ Estátua Prece } \\
\hline & $\mathbf{t}(\mathbf{m s})$ & $\mathbf{d}(\mathbf{c m})$ & $\mathbf{V}(\mathbf{m} / \mathbf{s})$ \\
\hline $\mathbf{1}$ & 166,4 & 20,0 & 1201,9 \\
\hline $\mathbf{2}$ & 128,2 & 20,6 & 1606,9 \\
\hline $\mathbf{3}$ & 75,4 & 22,0 & 2917,8 \\
\hline $\mathbf{4}$ & 41,9 & 22,5 & 5369,9 \\
\hline Média & & & $\mathbf{2 7 7 4 , 1}$ \\
\hline Desvio Padrão & & & $\mathbf{1 8 7 9 , 1}$ \\
\hline Coef. De Var. & & & $\mathbf{6 7 , 7}$ \\
\hline
\end{tabular}

\begin{tabular}{|c|c|c|c|}
\hline \multicolumn{4}{|c|}{ Estátua Prece } \\
\hline & $\mathbf{t}(\mathbf{m s})$ & $\mathbf{d}(\mathbf{c m})$ & $\mathbf{V} \mathbf{( m / s})$ \\
\hline $\mathbf{1}$ & 38,7 & 20,0 & 5168,0 \\
\hline $\mathbf{2}$ & 38,8 & 20,6 & 5309,3 \\
\hline $\mathbf{3}$ & 42,4 & 22,0 & 5188,7 \\
\hline $\mathbf{4}$ & 40,3 & 22,5 & 5583,1 \\
\hline $\mathbf{5}$ & 45,5 & 24,2 & 5318,7 \\
\hline $\mathbf{7}$ & 52,1 & 26,2 & 5028,8 \\
\hline $\mathbf{8}$ & 53,8 & 26,5 & 4925,7 \\
\hline $\mathbf{6}$ & 327 & 27,2 & 831,8 \\
\hline Média & & & $\mathbf{5 2 1 7 , 5}$ \\
\hline Desvio Padrão & & & $\mathbf{2 1 4 , 6}$ \\
\hline Coef. De Var. & & & $\mathbf{4 , 1}$ \\
\hline
\end{tabular}

\begin{tabular}{|c|c|c|c|}
\hline \multicolumn{4}{|c|}{ Estátua Prece } \\
\hline & $\mathbf{t}(\mathbf{m s})$ & $\mathbf{d} \mathbf{( c m})$ & $\mathbf{V} \mathbf{( m / s})$ \\
\hline $\mathbf{1}$ & 38,7 & 20,0 & 5168,0 \\
\hline $\mathbf{2}$ & 38,8 & 20,6 & 5309,3 \\
\hline $\mathbf{3}$ & 42,4 & 22,0 & 5188,7 \\
\hline $\mathbf{4}$ & 40,3 & 22,5 & 5583,1 \\
\hline $\mathbf{5}$ & 45,5 & 24,2 & 5318,7 \\
\hline $\mathbf{7}$ & 52,1 & 26,2 & 5028,8 \\
\hline $\mathbf{8}$ & 53,8 & 26,5 & 4925,7 \\
\hline $\mathbf{6}$ & 327 & 27,2 & 831,8 \\
\hline Média & & & 5217,5 \\
\hline Desvio Padrão & & & $\mathbf{2 1 4 , 6}$ \\
\hline Coef. De Var. & & & $\mathbf{4 , 1}$ \\
\hline
\end{tabular}


Túmulo de Luisa Crema Marzorati (1922)

\begin{tabular}{|c|c|c|c|}
\hline \multicolumn{4}{|c|}{ Estátua } \\
\hline & $\mathbf{t}$ (ms) & $\mathbf{d}(\mathbf{c m})$ & $\mathbf{V ~ ( m / s )}$ \\
\hline $\mathbf{2}$ & 93,0 & 46,0 & 4946,2 \\
\hline $\mathbf{3}$ & 90,9 & 46,0 & 5060,5 \\
\hline $\mathbf{4}$ & 91,4 & 46,0 & 5032,8 \\
\hline $\mathbf{5}$ & 23,0 & 12,0 & 5217,4 \\
\hline $\mathbf{6}$ & 22,6 & 12,0 & 5309,7 \\
\hline $\mathbf{7}$ & 84,9 & 46,0 & 5418,1 \\
\hline Média & & & 5164,1 \\
\hline Desvio Padrão & & & $\mathbf{1 8 1 , 1}$ \\
\hline Coef. De Var. & & & 3,5 \\
\hline
\end{tabular}

\begin{tabular}{|c|c|c|c|}
\hline \multicolumn{4}{|c|}{ Estátua - Lado W } \\
\hline & $\mathbf{t}(\mathbf{m s})$ & $\mathbf{d} \mathbf{( c m})$ & $\mathbf{V ~ ( m / s )}$ \\
\hline $\mathbf{1 / 2}$ & 20,3 & 10,5 & 5172,4 \\
\hline $\mathbf{1 / 3}$ & 40,4 & 20,5 & 5074,3 \\
\hline $\mathbf{1 / 4}$ & 58,8 & 31,0 & 5272,1 \\
\hline $\mathbf{1 / 8}$ & 20,1 & 10,5 & 5223,9 \\
\hline $\mathbf{1 / 9}$ & 40,9 & 20,5 & 5012,2 \\
\hline $\mathbf{1 / 1 0}$ & 61,6 & 31,0 & 5032,5 \\
\hline $\mathbf{2 / 8}$ & 10,4 & 6,1 & 5865,4 \\
\hline $\mathbf{3 / 9}$ & 10,9 & 6,1 & 5596,3 \\
\hline $\mathbf{4 / 1 0}$ & 10,9 & 6,1 & 5596,3 \\
\hline Média & & & 5316,2 \\
\hline Desvio Padrão & & & 300,2 \\
\hline Coef. De Var. & & & 5,6 \\
\hline
\end{tabular}

\begin{tabular}{|c|c|c|c|}
\hline \multicolumn{4}{|c|}{ Estátua - Lado E } \\
\hline & $\mathbf{t}(\mathbf{m s})$ & $\mathbf{d} \mathbf{( c m})$ & $\mathbf{V}(\mathbf{m} / \mathbf{s})$ \\
\hline $\mathbf{1 / 2}$ & 18,6 & 10,5 & 5645,2 \\
\hline $\mathbf{1 / 3}$ & 37,1 & 20,5 & 5525,6 \\
\hline $\mathbf{1 / 4}$ & 54,9 & 31,0 & 5646,6 \\
\hline $\mathbf{1 / 8}$ & 18,9 & 10,5 & 5555,6 \\
\hline $\mathbf{1 / 9}$ & 36,7 & 20,5 & 5585,8 \\
\hline $\mathbf{1 / 1 0}$ & 56,1 & 31,0 & 5525,8 \\
\hline $\mathbf{2 / 8}$ & 10,7 & 6,1 & 5700,9 \\
\hline $\mathbf{3 / 9}$ & 10,4 & 6,1 & 5865,4 \\
\hline $\mathbf{4 / 1 0}$ & 11,5 & 6,1 & 5304,3 \\
\hline Média & & & 5595,0 \\
\hline Desvio Padrão & & & $\mathbf{1 5 2 , 2}$ \\
\hline Coef. De Var. & & & $\mathbf{2 , 7}$ \\
\hline
\end{tabular}




\begin{tabular}{|c|c|c|c|}
\hline \multicolumn{4}{|c|}{ Estátua - Lado W } \\
\hline \multicolumn{4}{|c|}{ Transdutor 54 kHz $\mathbf{~ M e ́ t o d o ~ S e m i d i r e t o ~}$} \\
\hline $\mathbf{1 / 2}$ & $\mathbf{t}(\mathbf{m s})$ & $\mathbf{d}(\mathbf{c m})$ & $\mathbf{V}(\mathbf{m} / \mathbf{s})$ \\
\hline $\mathbf{1 / 3}$ & 32,7 & 11,5 & 3516,8 \\
\hline $\mathbf{1 / 4}$ & 50,4 & 19,9 & 3948,4 \\
\hline $\mathbf{1 / 8}$ & 75,1 & 29,7 & 3954,7 \\
\hline $\mathbf{1 / 9}$ & 25,2 & 11,5 & 4563,5 \\
\hline $\mathbf{1 / 1 0}$ & 47,5 & 20,6 & 4336,8 \\
\hline $\mathbf{2 / 8}$ & 71,3 & 31,9 & 4474,1 \\
\hline $\mathbf{3 / 9}$ & 14,9 & 8,0 & 5369,1 \\
\hline $\mathbf{4 / 1 0}$ & 16,4 & 8,0 & 4878,0 \\
\hline Média & 17,3 & 8,0 & 4624,3 \\
\hline Desvio Padrão & & & 4407,3 \\
\hline Coef. De Var. & & & 551,8 \\
\hline
\end{tabular}

\begin{tabular}{|c|c|c|c|}
\hline \multicolumn{4}{|c|}{ Estátua - Lado E } \\
\hline & $\mathbf{t}(\mathbf{m s})$ & $\mathbf{d} \mathbf{( c m})$ & $\mathbf{V ~ ( m / s )}$ \\
\hline $\mathbf{1 / 2}$ & 22,3 & 11,5 & 5157,0 \\
\hline $\mathbf{1 / 3}$ & 49,1 & 19,9 & 4053,0 \\
\hline $\mathbf{1 / 4}$ & 71,2 & 29,7 & 4171,3 \\
\hline $\mathbf{1 / 8}$ & 25,6 & 11,5 & 4492,2 \\
\hline $\mathbf{1 / 9}$ & 70,6 & 20,6 & 2917,8 \\
\hline $\mathbf{1 / 1 0}$ & 95,9 & 31,9 & 3326,4 \\
\hline $\mathbf{2 / 8}$ & 16,4 & 8,0 & 4878,0 \\
\hline $\mathbf{3 / 9}$ & 17,2 & 8,0 & 4651,2 \\
\hline $\mathbf{4 / 1 0}$ & 18,2 & 8,0 & 4395,6 \\
\hline Média & & & 4226,9 \\
\hline Desvio Padrão & & & 718,1 \\
\hline Coef. De Var. & & & 17,0 \\
\hline
\end{tabular}

Túmulo da Marquesa de Santos (1867)

\begin{tabular}{|c|c|c|c|}
\hline \multicolumn{4}{|c|}{ Pilar P1 } \\
\hline & $\mathbf{t}(\mathbf{m s})$ & $\mathbf{d} \mathbf{( c m})$ & $\mathbf{V} \mathbf{( m / s})$ \\
\hline $\mathbf{3}$ & 27,3 & 8,6 & 3150,2 \\
\hline $\mathbf{2}$ & 27,4 & 8,6 & 3138,7 \\
\hline $\mathbf{1}$ & 30,0 & 8,6 & 2866,7 \\
\hline Média & & & 3051,8 \\
\hline Desvio Padrão & & & $\mathbf{1 6 0 , 5}$ \\
\hline Coef. De Var. & & & 5,3 \\
\hline
\end{tabular}




\begin{tabular}{|c|c|c|c|}
\hline \multicolumn{4}{|c|}{ Pilar P2 } \\
\hline & $\mathbf{t}(\mathbf{m s})$ & $\mathbf{d} \mathbf{( c m})$ & $\mathbf{V ~ ( m / s )}$ \\
\hline $\mathbf{6}$ & 27,0 & 8,6 & 3185,2 \\
\hline $\mathbf{5}$ & 26,7 & 8,6 & 3221,0 \\
\hline $\mathbf{4}$ & 27,3 & 8,6 & 3150,2 \\
\hline Média & & & 3185,4 \\
\hline Desvio Padrão & & & 35,4 \\
\hline Coef. De Var. & & & $\mathbf{1 , 1}$ \\
\hline
\end{tabular}

\begin{tabular}{|c|c|c|c|}
\hline \multicolumn{4}{|c|}{ Pilar P3 } \\
\hline & $\mathbf{t}(\mathbf{m s})$ & $\mathbf{d} \mathbf{( c m})$ & $\mathbf{V ~ ( m / s )}$ \\
\hline $\mathbf{9}$ & 29,4 & 8,6 & 2925,2 \\
\hline $\mathbf{8}$ & 29,9 & 8,6 & 2876,3 \\
\hline $\mathbf{7}$ & 31,5 & 8,6 & 2730,2 \\
\hline Média & & & 2843,9 \\
\hline Desvio Padrão & & & 101,5 \\
\hline Coef. De Var. & & & 3,6 \\
\hline
\end{tabular}

\begin{tabular}{|c|c|c|c|}
\hline \multicolumn{4}{|c|}{ Pilar P4 } \\
\hline & $\mathbf{t}(\mathbf{m s})$ & $\mathbf{d} \mathbf{( c m})$ & $\mathbf{V} \mathbf{( m / s})$ \\
\hline $\mathbf{1 2}$ & 27,5 & 8,6 & 3127,3 \\
\hline $\mathbf{1 1}$ & 30,1 & 8,6 & 2857,1 \\
\hline $\mathbf{1 0}$ & 32,0 & 8,6 & 2687,5 \\
\hline Média & & & $\mathbf{2 8 9 0 , 6}$ \\
\hline Desvio Padrão & & & $\mathbf{2 2 1 , 8}$ \\
\hline Coef. De Var. & & & 7,7 \\
\hline
\end{tabular}




\section{ANEXO 2 \\ Cemitério da Consolação registra aumento no número de furtos}

Folha de S.Paulo - 03/10/2011 - 06h40

Quadra 54, sepultura 17, Cemitério da Consolação: montinhos de areia indicam o lugar em que estavam até quarta passada dois vasos de bronze, $40 \mathrm{~kg}$ cada. A poucos passos, no túmulo da família Margutti, um buraco marca a ausência do portão, furtado de quarta para quinta. Atrás, a planta jogada ao chão denuncia outro vaso levado na mesma noite.

Apesar de comuns há pelo menos um ano, os furtos de portões, vasos, jardineiras, placas, alças e até bustos do único cemitério municipal tombado na cidade explodiram neste mês de setembro. Quem diz isso são as pessoas que mais convivem com aquelas peças: os funcionários do cemitério e autônomos contratados pelas famílias para fazer a manutenção diária dos jazigos. Oito deles falaram em furtos de mais de 300 peças neste mês.

"Está fora de controle, desta magnitude nunca vi", diz Fernando Pinheiro, 34, que limpa túmulos há dez anos.

Os furtos ocorrem mesmo à luz do dia. A última prisão em flagrante foi na manhã de quinta, mesmo dia em que sete vasos amanheceram encostados num muro da rua Mato Grosso, como que à espera de um carregador. Segundo um sepultador, há poucos dias um carro encostou na rua da Consolação, às 18h, e dois homens passaram vasos por cima do muro. Três pontos do arame farpado estão amassados, mostrando os lugares mais usados como passagem.

Também não é difícil entrar pela porta da frente e se esconder ali: a área tem 76,3 mil $\mathrm{m}^{2}$ e 8.200 túmulos. No mercado de ferro velho, uma peça de bronze é vendida por cerca de $\mathrm{R} \$ 5$ o quilo. De cobre, sobe para $\mathrm{R} \$ 9$.

Assim, portões de bronze que pesam em torno de $35 \mathrm{~kg}$ rendem $\mathrm{R} \$ 175$, pagos à vista, no comércio de metais. Na madrugada da última quarta, levaram o letreiro da família Mesquita Campos, que custou R\$350 a Sidney Campos, 59. Só sobrou pedra.

"Logo vai ter que ter um guia turístico para mostrar o que foi roubado", ele ironiza.

Em duas horas de passeio, a Folha não viu nenhum guarda no cemitério, na última quinta. Também não há câmeras -promessa da prefeitura desde 2008. A prefeitura diz que o Serviço Funerário "vem intensificando a segurança em todas as necrópoles", com apoio da Guarda Civil Metropolitana e que houve nove prisões em flagrante neste ano na Consolação. 
Ela diz não saber quantos foram os furtos, mas que a administração do cemitério não notou aumento recente. Também informou que as famílias pagam pela concessão do terreno ( $\left.\mathrm{R} \$ 3.173 / \mathrm{m}^{2}\right)$ e devem custear a conservação e a segurança, isentando o Serviço Funerário de "quaisquer responsabilidades administrativa, civil e criminal" no caso de furtos de materiais de valor. 


\section{ANEXO 3 \\ Homem é preso por furto no cemitério da Consolação, em SP}

Folha de S.Paulo - 20/10/2009 - 18h56

Um homem foi detido na noite de ontem acusado pela polícia de furtar diversas peças de túmulos do cemitério da Consolação, na região central de São Paulo.

De acordo com a Secretaria da Segurança Pública (SSP), o homem, de 28 anos, saía do cemitério, por volta das $20 \mathrm{~h} 30$, com um carrinho de mão com as peças quando foi abordado por policiais militares. No carrinho havia pequenas janelas e pedaços de bronze e ferro que enfeitavam túmulos.

A polícia foi ao local após receber o telefonema de um anônimo, que informou ter visto um homem no cemitério com um carrinho. Ele confessou o crime e foi autuado em flagrante por tentativa de furto no $4^{\circ} \mathrm{DP}$ (Consolação).

Aos policiais, o homem disse ter retirado as peças porque precisava "angariar dinheiro e comprar um carrinho de mão" novo. A suspeita é de que ele tenha entrado no cemitério por uma fresta existente no portão.

A Guarda Civil Metropolitana, que é responsável pela segurança do cemitério, não localizou os túmulos violados. O acusado está detido no $2^{\circ} \mathrm{DP}$ (Bom Retiro). Por ser tentativa, a pena de furto, de um a quatro anos de prisão, pode ser diminuída de 1/3 a 2/3. 


\section{ANEXO 4 \\ Prefeitura vai instalar câmeras nos cemitérios de SP}

Folha de S.Paulo - 22/03/2012 - 17h04

Devido ao alto número de furtos, a Prefeitura de São Paulo pretende instalar câmeras de segurança nos cemitérios municipais para tentar reduzir as ocorrências que desfalcam os túmulos da cidade.

A ação pretende inibir o furto de peças como vasos de bronze, portões, jardineiras, placas, alças, letreiros e bustos, que são levadas todos os anos dos jazigos paulistanos.

No mercado de ferro velho, portões de bronze que pesam em torno de $35 \mathrm{~kg}$ rendem $\mathrm{R} \$ 175$, pagos à vista.

Ao todo, 15 câmeras serão instaladas em locais estratégicos em cemitérios da cidade ainda no primeiro semestre de 2012, inclusive no Cemitério da Consolação. As imagens captadas serão compartilhadas entre a GCM (Guarda Civil Metropolitana) e a Polícia Militar.

A assessoria de imprensa da GCM não soube informar o valor do investimento da instalação das câmeras de segurança.

Segundo o Serviço Funerário de São Paulo, nos últimos 15 meses a GCM efetuou 16 prisões em flagrante, sendo que 27 pessoas foram indiciados por crime de furto. Destas detenções, oito ocorreram no Cemitério Consolação, um dos mais antigos da cidade.

As ocorrências registradas nos 22 cemitérios municipais são encaminhadas às autoridades policiais. No entanto, a Secretaria de Segurança do Estado de São Paulo afirma que não possui dados específicos sobre furtos a cemitérios.

De acordo com a autarquia, o número de ocorrências em cemitérios diminuiu $36 \%$ nos últimos dois anos.

O Serviço Funerário solicita que os munícipes compareçam à administração dos cemitérios para fazer o reconhecimento de itens recuperados. Pede também que, ao constatar a falta de alguma peça no jazigo da família, registre sempre um boletim de ocorrência. 


\section{ANEXO 5}

\section{Uma sanfona para São Paulo}

Folha de S.Paulo - 04/01/2004

Ele nasceu em Veneza, é autor da música mais conhecida do Pantanal, criou o hino do $4^{\circ}$ Centenário de São Paulo e do "4 Centenário e Meio", é considerado um dos sanfoneiros mais importantes do Brasil, poderia ter sido o avô de Sandy e Junior e, de quebra, mexeu seus pauzinhos para ser enterrado ao lado de seu ídolo maior, a Marquesa de Santos.

Teve razão a Prefeitura de São Paulo ao decidir dar uma comenda a Mário Zan na cerimônia da virada 2003/2004, já como parte das comemorações dos 450 anos da cidade: aos 83 anos, o acordeonista, com suas contradições e multiatividades, é o retrato definido da cidade, um paulistano mais do que honorário.

Ao começo da história, então, conforme conta à Folha agora este senhor de voz profunda e olhos tristes que preferiu dar entrevista na Redação em vez de em sua casa, no prédio da esquina da avenida São João com a praça Júlio Mesquita que um dia já foi loja do Mappin -na portaria do jornal, uma senhora de seus 60 e poucos anos o reconheceu e cobriu-o de elogios; saiu com um CD autografado. "Ela disse que era minha fã há 50 anos."

Tudo na vida de Mário Zan é contado em décadas ou metades de século, como se verá.

\section{Moleque da sanfona}

Mário João Zandomeneghi é italiano de Veneza, onde nasceu em 1920. Quando tinha quatro anos, seus pais o trouxeram para o Brasil. Seu José trabalhava em olaria e vinhedo, dona Ema era "do lar"; foram morar em Santa Adélia, perto de Catanduva (SP). Aos 12 anos, já tocador de acordeão bom o suficiente para ganhar a alcunha "Moleque da Sanfona", mudou-se para as imediações do Museu do Ipiranga.

Os anos seguintes -como vizinho de nomes tão ilustres quanto D. Pedro $1^{\circ}$ e Santos Dumont- de certa maneira marcaram sua vida. Das capas dos discos, que quase sempre trariam uma referência ao bairro, aos temas de músicas. "Quando chegamos era tudo mato à volta e no meio o museuzão, imponente", lembra. "Morávamos numa casinha, eu e sete irmãos e meus pais."

Aos 13, estreou como sanfoneiro profissional. Desde então, os números são eloquentes: nos 70 anos seguintes, comporia cem músicas (das quais pelo menos um terço seria regravado por gente como Roberto Carlos e Almir Sater), registraria 200 canções, 300 discos de 78 rotações, 110 LPs e mais de 50 CDs. "Comecei gravando em cera, ali onde era 
a gravadora Continental, na praça Pérola Byington", afirma. "De lá para cá, gravei em tudo que foi meio que foi inventado, do compacto simples ao disco digital."

O primeiro meio de comunicação que conheceu sua sanfona foi o rádio - Mário Zan é pré-televisão. Foi na Record, quando a emissora ficava na esquina da rua Quintino Bocaiúva com a rua Direita, no centro, no mesmo prédio onde depois a editora de músicas Irmãos Vitale fez sua sede. "Entrei para pedir para tocarem minhas músicas, saí de lá 33 anos depois, esse tempo todo empregado com carteira registrada."

Nessa época, um locutor ouviu a batida inconfundível de Zan nos teclados e ficou encantado. Em seu programa de rádio do Rio de Janeiro, deu a bronca: "Enquanto nós cariocas ficamos babando para os gringos, ouvindo música estrangeira e imitando, existe um sanfoneiro em São Paulo que faz verdadeira música brasileira". O nome do locutor era Ary Barroso (1903-1964), o criador de "Aquarela do Brasil".

\section{Nova flor}

Um de seus maiores sucessos até hoje é "Nova Flor", mais conhecida como "Os Homens Não Devem Chorar" ("Dizem que um homem/ Não deve chorar/ Por uma mulher/ Que não soube amar"), gravada por pelo menos 200 intérpretes em toda a América Latina (há uma versão em espanhol mais conhecida do que a original) mais países da língua inglesa ("Love Me Like a Stranger") e até na Alemanha, onde Howard Carpendale a "eternizou" na língua de Goethe.

Mas Mário Zan talvez fique para sempre conhecido como o sujeito que compôs o hino dos 400 anos de uma cidade e meio século mais tarde criou uma música em homenagem aos 450 anos da mesma cidade - São Paulo, claro. Além do feito cronológico, "Quarto Centenário" é também um "case" que a indústria fonográfica nacional gosta de contar.

Com 10 milhões de cópias até hoje, o disco em 78 rpm com o hino vendeu mais exemplares em 1954 do que havia vitrola no Brasil. Só nos primeiros meses, foram 1 milhão de bolachas da música, que começa com "''São Paulo, meu São Paulo, São Paulo quatrocentão", com sanfona -óbvio- e uma marcação forte de baixo-tuba. "'Fazia um "pom", "pom" que pegou logo."

Zan tinha 33 anos então e nem sonhava em estar por aqui nos 450 anos. "Mas, já que eu estava, e já que esta cidade me deu tanto, resolvi arriscar e fazer outro hino." A música não foi adotada oficialmente, mas valeu da prefeitura um convite para que o sanfoneiro recebesse o título de cidadão honorário na virada de 2003 para 2004, em cerimônia na avenida Paulista. E outro CD, que já está à venda.

O curioso é que não é de São Paulo que vem o grosso de seu faturamento, mas de umas terras encharcadas bem longe daqui. No caso, o Pantanal mato-grossense, onde Mário Zan é tratado como o Luiz Gonzaga do atoleiro. Sua "Asa Branca" é "Chalana", hino 
nacional da região, que ganhou o resto do país em 1990, ao virar tema da novela "Pantanal", da extinta TV Manchete.

"Lá vai uma chalana/ Bem longe se vai/ Navegando no remanso/ Do rio Paraguai", começam os versos, referindo-se às pequenas embarcações típicas do lugar. Na verdade, quando compôs a música, em 1940, em parceria com Arlindo Pinto, o sanfoneiro nunca tinha colocado os pés ali, o que só veio a fazer anos e anos depois, já em excursões que levavam multidões a seus shows.

A fama the valeu, nos anos 50, um namoro arrebatador com uma bonita menina da região, que durou seis anos e acabou deixando saudade, pelo menos em Zan. Pois a moça era dona Mariazinha, que viria a se casar com o cantor sertanejo Zé do Rancho; os dois teriam Noely, que se casaria com Xororó e geraria Sandy Leah Lima e Durval de Lima Júnior. "Se o mundo não tivesse dado voltas, eu poderia hoje ser o avô de Sandy e Júnior", brinca.

Não que ele se queixe. Segundo números publicados em reportagem do site de economia Invest News, em 2002, que o próprio fez questão de não negar nem confirmar, Mário Zan vende em média 600 mil discos por ano, a maioria durante as festas juninas; faz entre cinco e seis shows por mês, a $R \$ 5$ mil cada um; e recebe entre $R \$ 500$ e $R \$ 600$ por mês de direitos autorais. "Isso é uma miséria, culpa da roubalheira que domina este nosso mercado", reclama.

\section{Marquesa de Santos}

Mas nada parece tirar do sério o suave sanfoneiro, casado pela terceira vez, pai de três filhos e duas filhas, exceto o assunto marquesa de Santos, ao qual se dedica há cinco anos. "É uma injustiça a fama que essa mulher tem no Brasil", exalta-se. "'Ela foi uma alma pura, que antes de morrer doou toda a riqueza que tinha, dividiu os bens entre seus escravos e a cidade de São Paulo, não dá para ela entrar para a história como "amante de dom Pedro 1"

Lendo um livro sobre a vida de Domitila de Castro Canto e Mello (1797-1867), a polêmica marquesa de Santos, que teve um "affaire" com o então imperador do Brasil, Mário Zan descobriu que ela estava enterrada no cemitério da Consolação. Resolveu visitar o túmulo. "Cheguei lá, estava tudo em petição de miséria, tinha despacho de macumba, pichação, muito lixo e até um pé de milho!", espanta-se. "Mandei limpar tudo, reformar a lápide e pago uma pessoa para ir lá toda a semana conservar e trocar as flores."

O próximo passo seria realizar um novo sonho: achar um túmulo à venda próximo ao da marquesa. "É que, desde que eu fiz isso por ela, minha vida mudou para melhor", revela, místico. Não foi fácil. Disputado, o cemitério, cujo terreno aliás foi doado pela própria Domitila, aloja os restos de gente como Monteiro Lobato e Mário de Andrade. 
Até que um amigo de um amigo conseguiu: um lugar bem em frente ao da marquesa, na quadra 1, na rua principal, a da capela. Agora, Mário Zan já sabe que vai passar a eternidade em boa companhia. "Mas não tenho pressa", avisa. "Ainda quero fazer outros hinos para São Paulo." 
ANEXO 6

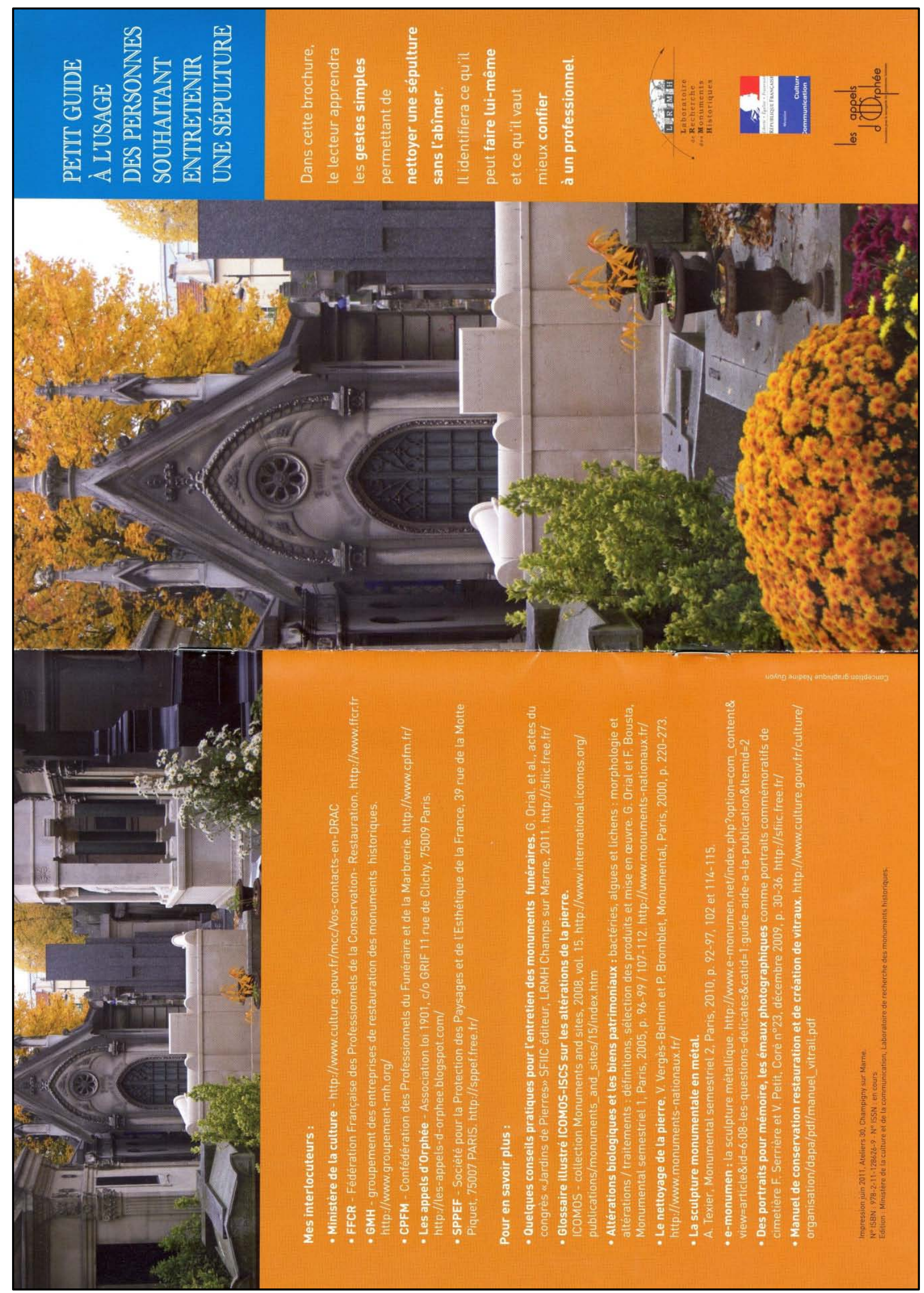




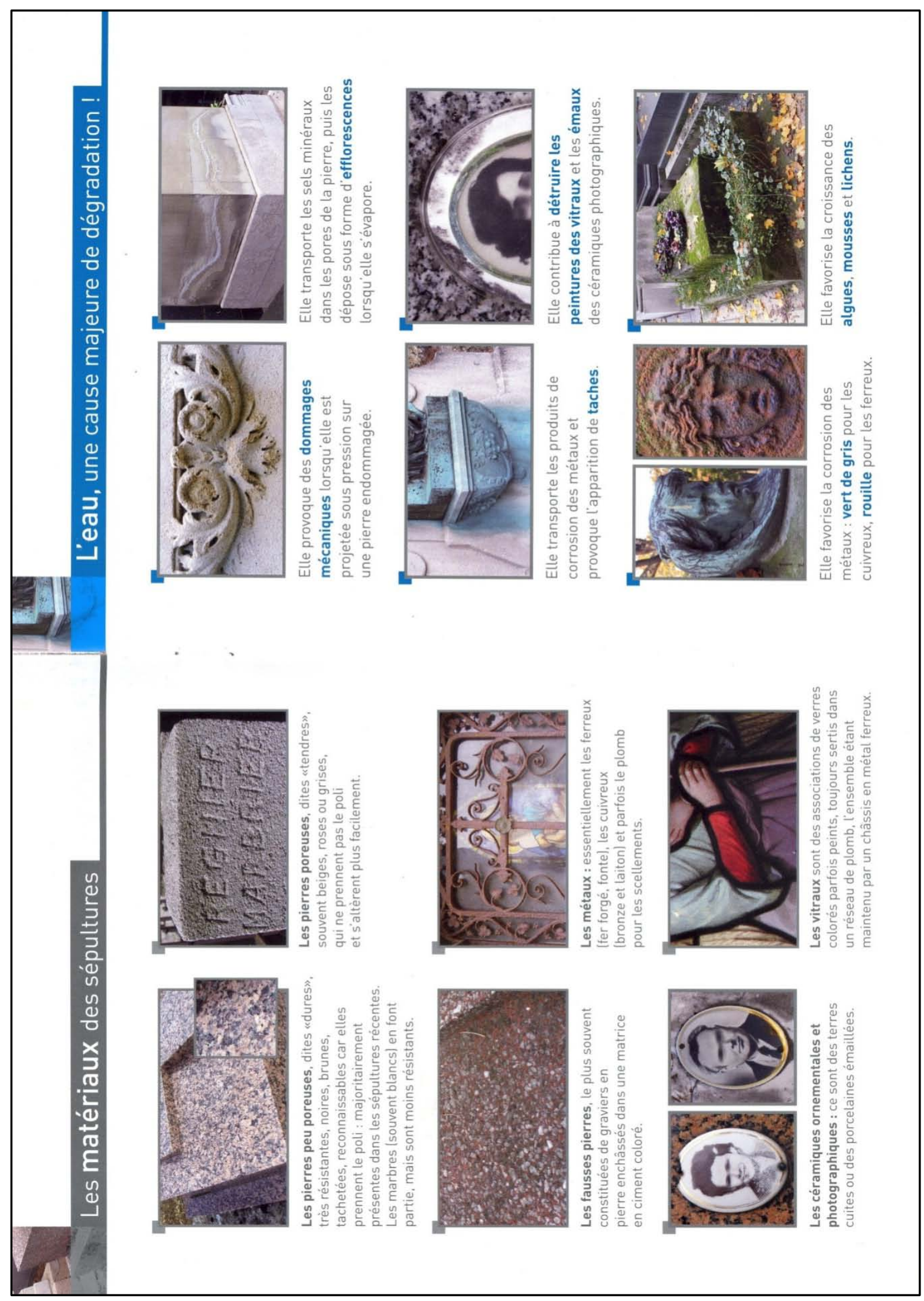




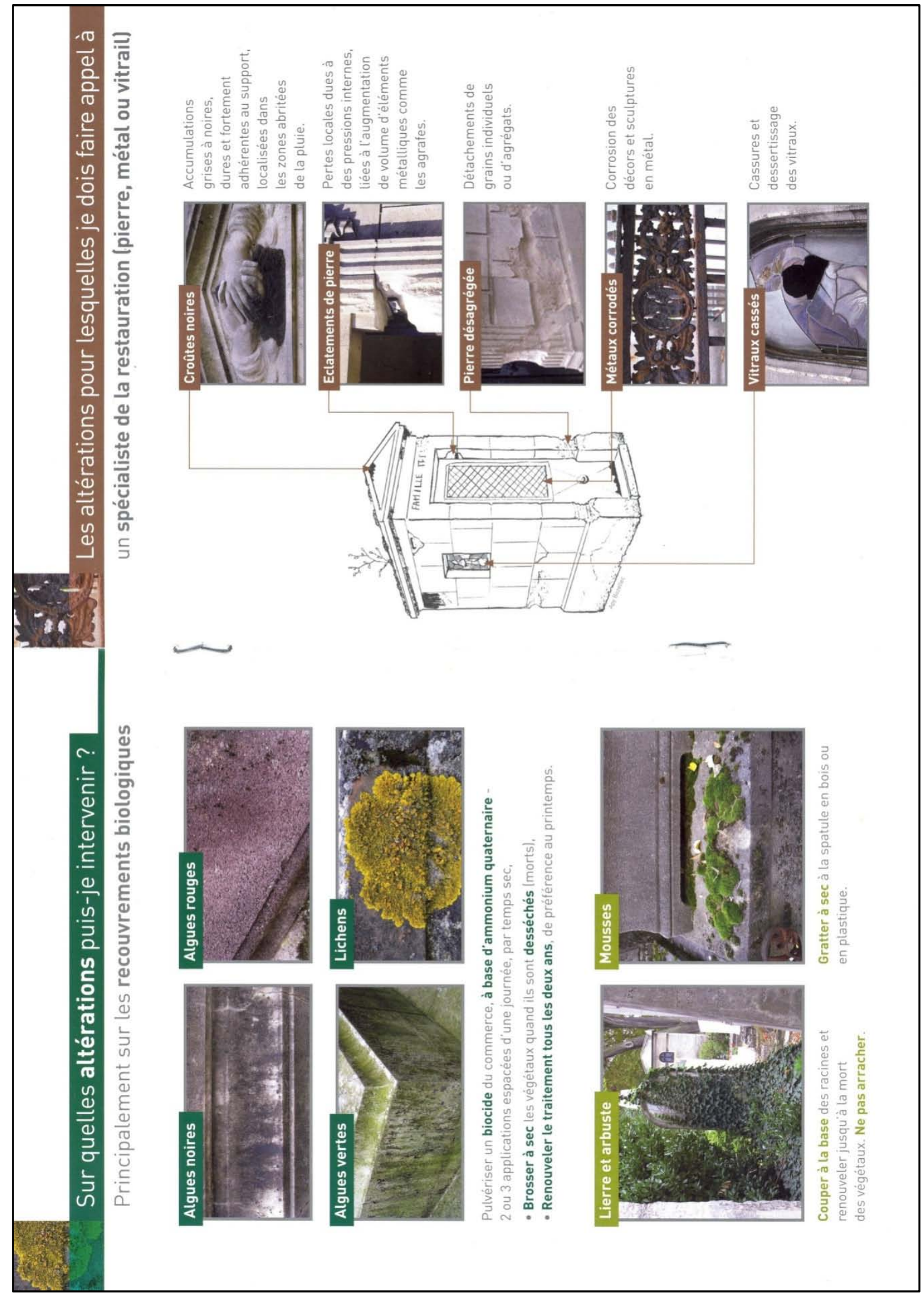




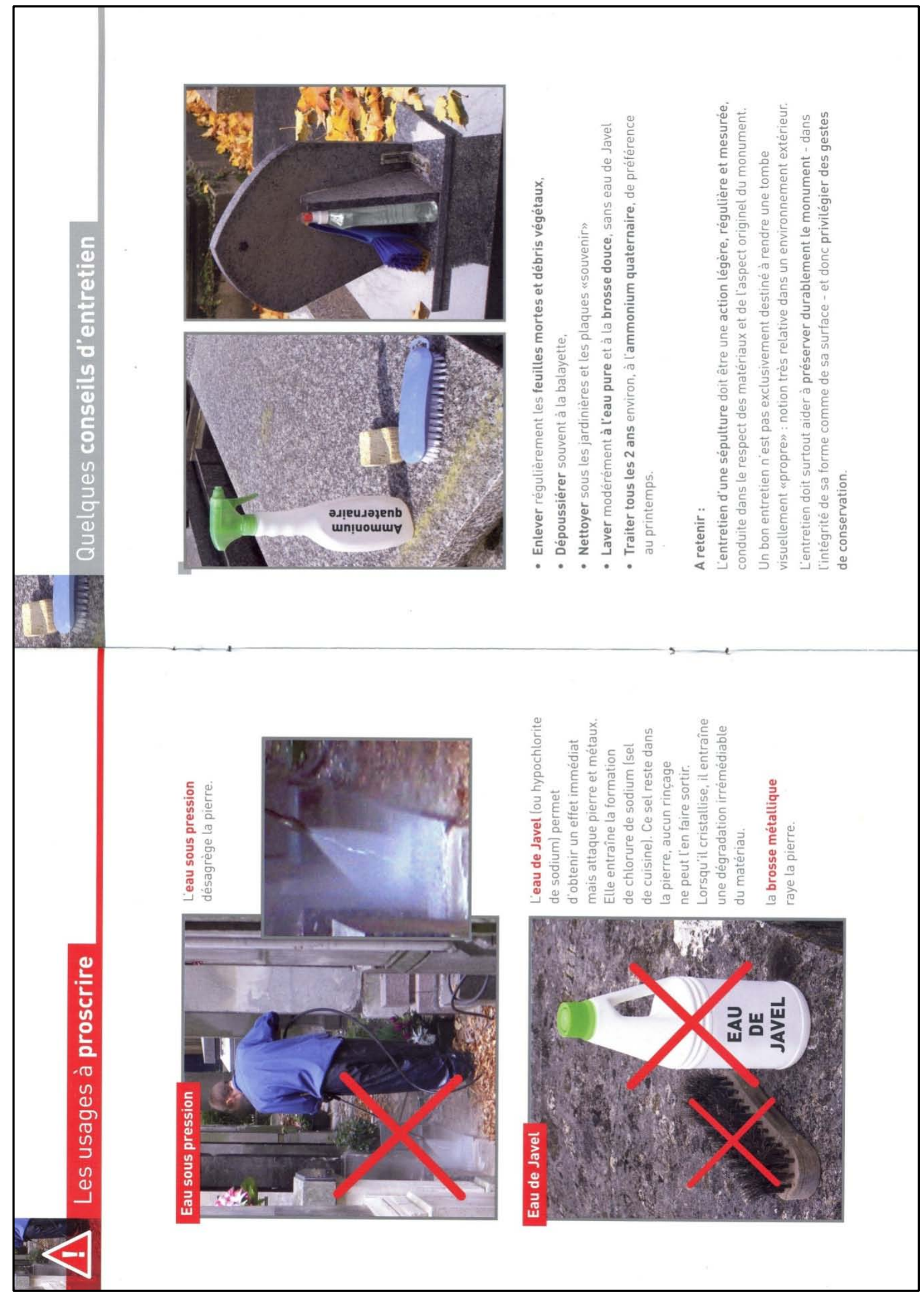


ANEXO 7

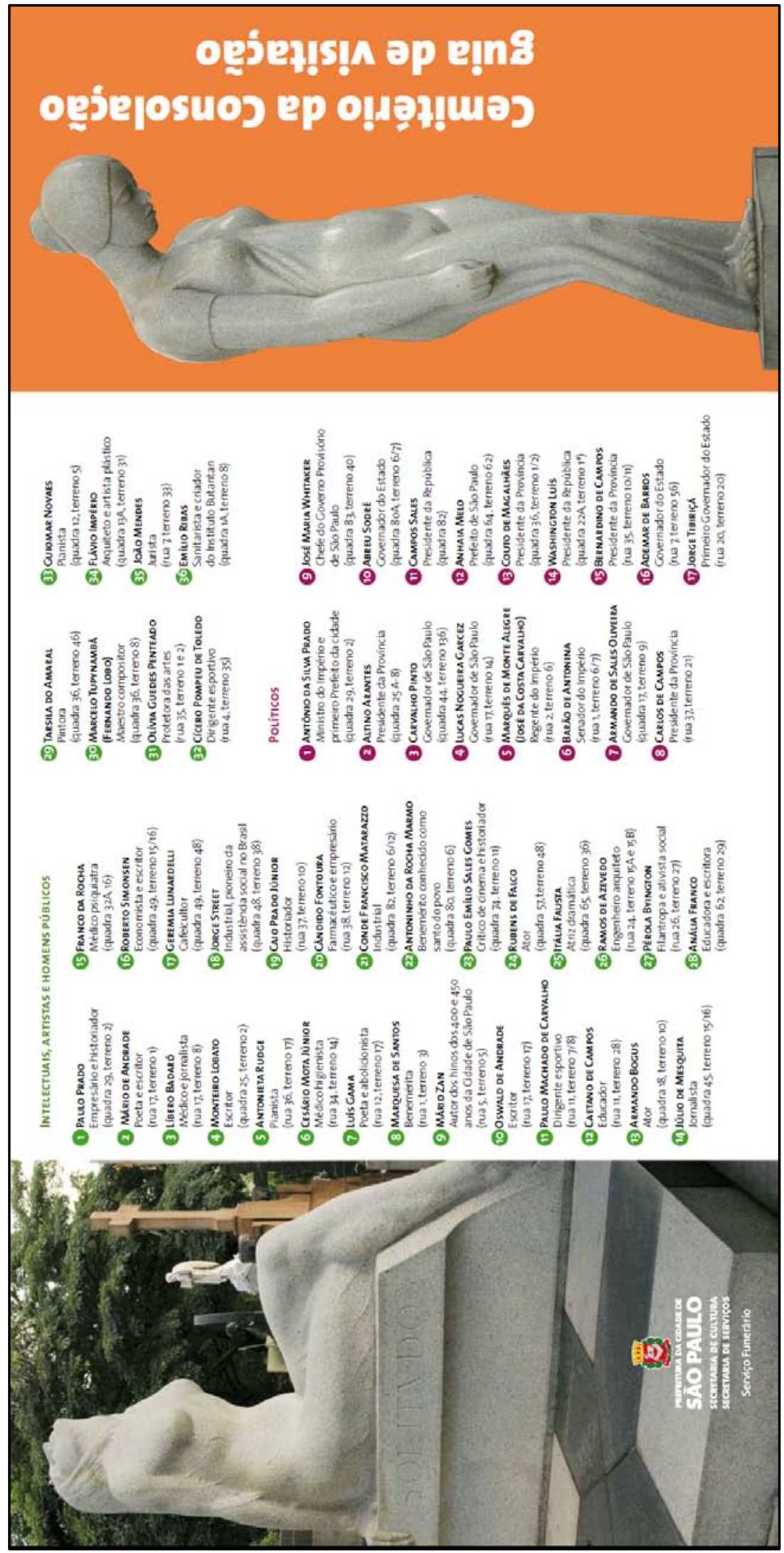




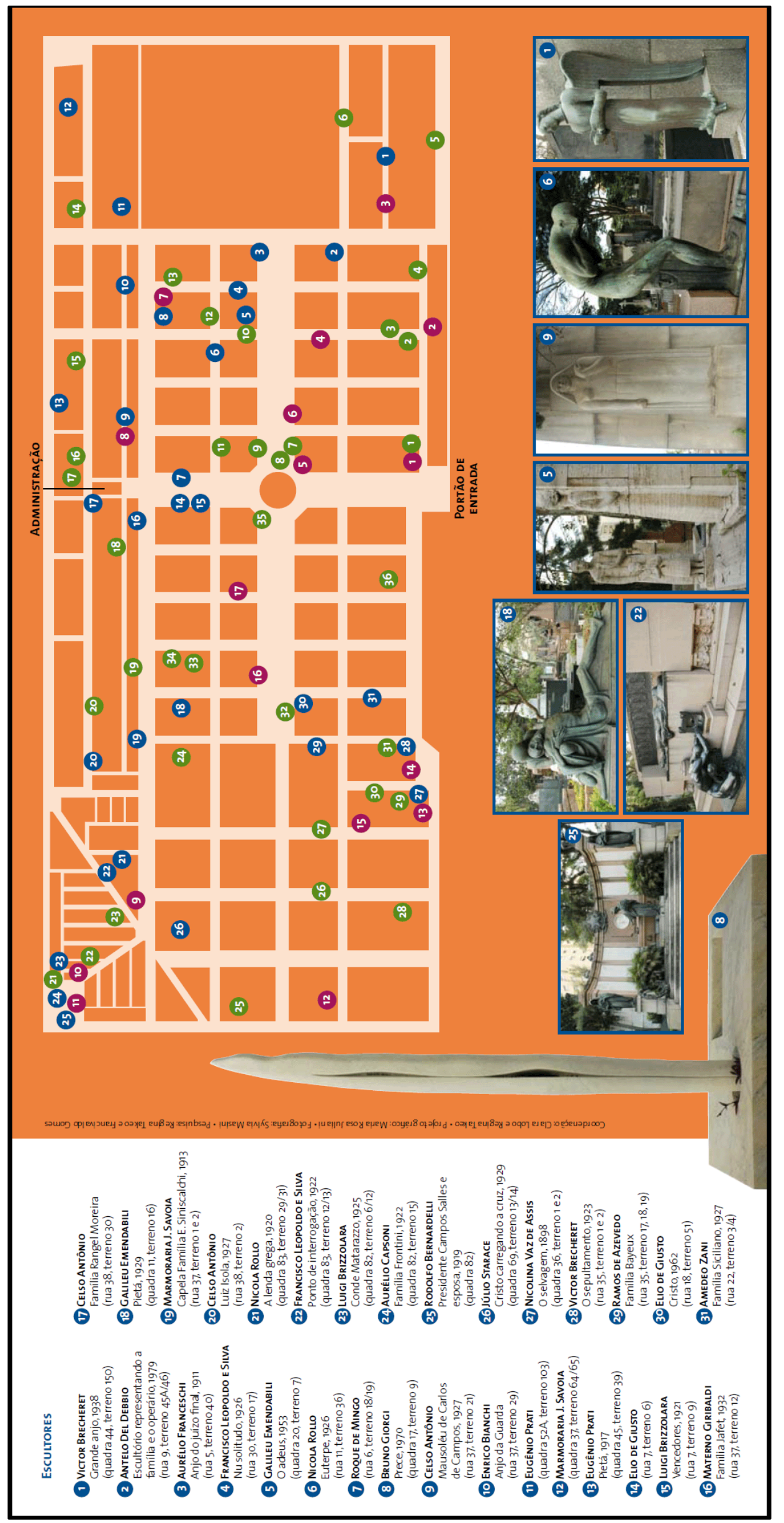

